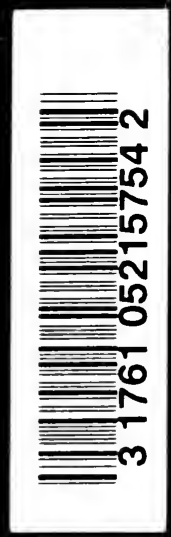



$\mid:$

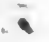

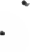

. 



\section{LECTURES ON THE}

EARLY HISTORY OF THE KINGSHIP 
sxis 


\title{
LECTURES ON THE
}

\section{EARLY HISTORY OF THE KINGSHIP}

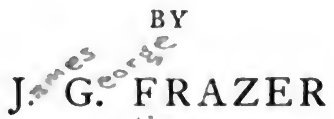

HON, D.C.L. OXFORD, MON. LL.D. GLASGOW, HON, LITT.D. DURHAM

TELLOW OF TRINITY COLLEGE, CAMBRIDGe

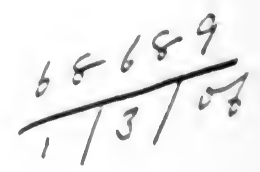

\author{
Zloñon \\ MACMILLAN AND CO,, Limited \\ NEW YORK: THE MACMILLAN COMPANY \\ 1905
}



EDMUND GOSSE

IN

GRATITUDE AND FRIENDSHIP 


\section{Digitized by the Internet Archive in 2007 with funding from Microsoft Corporation}




\section{PREFACE}

$T_{H E}$ following lectures were delivered at Trinity College, Cambridge, in the Lent term of this year, under the title of "The Sacred Character and Magical Functions of Kings in Early Society." The general theory here sketched of the evolution of the Kingship formed the subject of two lectures given in London at the Royal Institution last May. In preparing the manuscript for the press I have made a few unimportant changes, mostly verbal, and added references to my authorities. Otherwise the lectures are printed as they were spoken. Substantially they consist of a series of extracts from the forthcoming third edition of my book The Golden Bough, which will contain fuller information on many points.

Such prefatory remarks as I may have to make are reserved for that work, but I cannot allow this volume to go forth without an acknowledgment of the debt I owe to my friend Mr. A. B. Cook, Fellow and Lecturer of Queens' College, Cambridge. If I have been able to present my theory of the Arician kingship in a more probable, or at least a more precise, form than before, I owe the improvement chiefly to the stimulating 
viii

influence of his criticisms, which obliged me to reconsider the whole problem. Moreover, in working out my revised theory I have profited greatly by his learning and acumen, which he has generously placed at my disposal in the spirit of the good old maxim кouvà $\tau \grave{a}$ $\tau \hat{\omega} \nu \phi i \lambda \omega \nu$.

\section{J. G. FRAZER.}

Trinity College, Cambridge,

16 th August 1905. 


\section{CONTENTS}

\section{LECTURE I}

The history of institutions-Methods of the study - Reasons for preferring the inductive method-King of the Wood at Nemi-Characteristics of Diana at Nemi-Conversion of the festival of Diana into a feast of the Virgin Mary-Egeria-Virbius the mate of Diana-Summary of conclusions .

Pages $1-27$

\section{LECTURE II}

Priestly kings in antiquity-Relation of Spartan kings to Castor and Pollux - Incarnate gods-Kings as magicians - Principles of magicLaw of Similarity and Law of Contact-Homoepathic Magic and Contagious Magic-Both included under Sympathetic MagicExamples of Homøopathic Magic-Magical images-Cures based on Homøeopathic Magic-Use of Homoeopathic Magic in hunting and fishing-Negative Magic or taboo-Savage belief in magical telepathy . . . . . 28.59

\section{LECTURE III}

Magical telepathy in war-Homoeopathic Magic in relation to plants, animals, inanimate things, and the dead-Homoeopathic Magic used to annul evil omens-Examples of Contagious Magic-Magical contact between a wounded person and the weapon that hurt himMagical contact of footprints-Public magicians develop into kingsRisc of monarchy essential to the emergence of mankind from savagery 


\section{LECTURE IV}

The institution of a public order of magicians a great incentive to research-Public magicians expected to regulate the weatherMaking rain-Making sunshine-Making or calming wind Tendency of magicians to develop into kings in Australia, New Guinea, and Melanesia-The evolution complete in Africa-Similar evolution among the Malays-Traces of it in Europe-The divinity of kings . . . . . . . Pages 89-128

\section{LECTURE V}

Development of the magician into a god as well as a king-Incarnate human gods in Polynesia, Africa, and ancient Greece and GermanyWorship of the Brahmans in India-Human gods in Tibet and China-Divinity of the emperors of China and Japan-Worship of the kings of Babylon and Egypt-Summary of the evolution of the Kingship-King of the Wood at Nemi again considered-He seems to have been the mate of Diana, the two being considered as King and Queen of the Wood-Trees regarded as male and femaleMarriages of trees and plants . . . . 129-159

\section{LECTURE VI}

Marriage of the powers of vegetation-May King and Queen in Germany and England-Marriage of the gods in ancient Babylon, Egypt, and Greece-Similar rites in ancient Sweden and Gaul-Marriage of water-gods to human brides-Stories of the Perseus and Andromeda type-The Slaying of the Dragon at Furth-St. Romain and the Dragon of Rouen

. $160-193$

\section{LECTURE VII}

The Sacred Marriage-Numa and Egeria-Kings of Rome and Alba personified Jupiter, the god of the oak and the thunder-Sacred marriage of Jupiter and Juno perhaps enacted by the King and Queen of Rome-Roman kings regarded as sons of the fire god by his wives the Vestal Virgins-Sacred fires and Vestal Virgins in Ireland and Peru 


\section{LECTURE VIII}

Succession to Latin kingship in female line through marriage with king's daughter-Indifference to paternity of kings-African parallelsSons of kings go abroad and reign in their wives' country-Succession to kingdom through marriage with late king's widow-Evidence of female kinship among European peoples-Roman kings of plebeian or indigenous race-Abolition of kingship at Rome a patrician revolution -Attempt of Tarquin the Proud to alter succession from female to male line-Roman sovereignty partly hereditary, partly electivePersonal qualities required in candidates for kingship-Possession of princess and of crown determined by athletic contest-King's Flight at Rome . . . . . . Pages 229-264

\section{LECTURE IX}

The King's Flight at Rome in relation to the Saturnalia-Human representatives of Saturn killed at the Saturnalia-Violent deaths of Roman kings-Saturn and Jupiter-Summary of conclusions as to the King of the Wood at Nemi-He represented Jupiter or Janus and mated with Diana-Janus or Dianus and Diana the equivalents of Jupiter and Juno-Reasons for putting the divine king to death-The King of Calicut an Indian parallel to the King of the Wood at Nemi 


\section{LECTURE I}

The history of institutions-Methods of the study - Reasons for preferring the inductive method-King of the Wood at NemiCharacteristics of Diana at Nemi-Conversion of the festival of Diana into a feast of the Virgin Mary-Egeria-Virbius the mate of Diana-Summary of conclusions.

THE subject of these lectures is "The Sacred Character and Magical Functions of Kings in Early Society." But I must warn you at the outset that you will hear much less about kings than from the title of the lectures you might reasonably expect and perhaps wish to hear. The sacred character and magical functions of kings in early society cannot be understood without some knowledge of those general forms of superstition of which this aspect of the kingship is a particular expression; above all, we must acquaint ourselves with the elements of primitive magic, since the ancient king was often little more than the chief magician of his tribe. Several lectures will therefore be devoted to explaining and illustrating the elements of magic, and during their discussion the king will apparently be lost sight of entirely. I mention this at the beginning in order to prevent disappointment. For the same reason, I wish 
to say that the greater part, though not the whole, of the lectures will consist merely of fresh examples or illustrations of principles which I have already stated and exemplified elsewhere ${ }^{1}$ and, lastly, that, apart from a few introductory remarks, the substance of all that I shall say will be published before long in the new edition of my book, which is now in the press.

Before addressing myself to the special subject of the lectures, I desire to make a few general observations on the method I have followed in them.

Anthropology, or the study of man, claims a place for itself among the sciences. Of that study or science the history of institutions, with which we are here concerned, forms an important branch. It aims at tracing the growth, development, and decay of all human institutions from the earliest to the latest times, not merely recording the facts in chronological order, but referring them to their general causes in the physical and mental constitution of man and the influence of external nature. Now, if we are to pursue this study in a scientific spirit, we must endeavour to investigate the beliefs and customs of mankind with the same rigorous impartiality with which, for example, the zoologist investigates the habits of bees and ants. To attain that impartiality is indeed much harder for the anthropologist than for the zoologist, for the customs and superstitions even of the lowest savages touch us far more nearly than the habits even of the highest animals. The continuity of human development has been such that most, if not all, of the

${ }^{1}$ The Golden Bough, a Study in Magic and Religion, 2nd edition, London, 1900. 
great institutions which still form the framework of civilised society have their roots in savagery, and have been handed down to us in these later days through countless generations, assuming new outward forms in the process of transmission, but remaining in their inmost core substantially unchanged. Such, for example, to take a few conspicuous instances, are the institution of private property, the institution of marriage, the institution of war, and the worship of a god. Differences of opinion may exist, and have existed, as to the precise value of the inheritance; as to the fact of it there can be none. Thus in treating even of the rudest savages it is not easy, if I may say so, to keep our eyes fixed inflexibly on the object immediately before us. For we seem to be standing at the sources of human history, and it is difficult to exclude from our mind the thought of the momentous consequences which in other ages and other lands have flowed from these simple beginnings, often from these apparently harmless absurdities. And the further we descend the stream of history, and the nearer we approach to our own age and country, the harder it becomes to maintain an impartial attitude in the investigation of institutions which have been fraught with so much happiness and so much misery for mankind. Yet, if we are to succeed in the inquiry, we must endeavour to approach it without prejudice and to pursue it without passion, bearing in mind that our aim is simply the ascertainment of truth, not the apportionment of praise or blame; that we are not judges, still less advocates, but merely inquirers; 
that it is for us, in the language of Spinoza, humanas actiones non ridere, non lugere, neque detestari, sed intelligere. ${ }^{1}$

A science which rests on observation, as all the historical sciences necessarily do, may be taught in one of two ways. Either we may begin with a statement of general principles and then proceed to illustrate it by individual cases; or, on the contrary, we may begin with the individual cases and from a comparison of them with each other may endeavour to elicit those general laws which, in common parlance, are said to govern the particulars. The former is the deductive method, the latter is the inductive.

Both methods have, like most other things, their respective advantages and disadvantages. The deductive method is, in appearance at least, the more scientific. There is an air of completeness, symmetry, and precision about it which is very taking. It gives us a bird's-eye view of a subject which is easily grasped by the mind and retained by the memory. It is thus admirably adapted for exposition on the side of the teacher, and for learning on the side of the pupil. In other words, it is the best mode of imparting and acquiring information, whether for the sake of examinations or for higher ends. For such purposes the inductive method is nearly useless. It plunges us at once into such a sea of

\footnotetext{
${ }^{1}$ Spinoza, Tractatus Politicus, i. 4: "Cum igitur animum ad Politicam applicucrim, nihil quod novum vel inauditum est, sed tantum ea, quae cum praxi uptime conveniunt, certa et indubitata ratione demonstrare, aut ex ipsa humanae naturae conditione deducere intendi; et ut ea, quae ad hanc scientiam spectant, eadem animi libertate, qua res Mathematicas sclemus, inquirerem, sedulo curavi, humanas actiones non ridere, non lugere, neque detestari, sed intelligere."
} 
particulars that it is difficult at first to find our bearings, that is, to perceive the general principles which are to reduce this seeming chaos to order. To adopt a common and expressive phrase, it is hard to see the wood for the trees. Yet the serious disadvantage under which the inductive method thus labours is perhaps more than compensated in another direction by one solid advantage-it is the method of discovery. In all sciences which rest on observation, discovery must ultimately proceed from the particular to the general, from the isolated observed instances to the abstract conception which binds them together. Apparent exceptions there are, but on examination they will always, I believe, be found to conform to the rule. Thus if the inductive method is unsuited to the acquisition, it is well suited to the extension, of knowledge; if it does not train a student for examinations, it trains him for research.

Apart from this general advantage possessed by the inductive method, there is a special reason why anthropology should adhere to it at the present time. In order to make a sound induction large collections of facts are necessary; hence in the inductive sciences it is essential that a period of collection should precede a period of generalisation. Not until great masses of observations have been accumulated and classified do the general laws which pervade them begin to appear on the surface. Now anthropology in general and the history of institutions in particular are still in the collecting stage. The prime want of the study is not so much theories as facts. This is especially true of 
that branch of the study which treats of origins; for, as I have said, most great institutions may be traced back to savagery, and consequently for the early history of mankind the savage is our most precious document. It is only of late years that the document has received the attention it deserves; and unfortunately it is perishing under our eyes. Contact with civilisation is rapidly effacing the old beliefs and customs of the savage, and is thereby obliterating records of priceless value for the history of our race. The most urgent need of anthropology at present is to procure accurate accounts of the existing customs and ideas of savages before they have disappeared. When these have been obtained, when the records existing in our libraries have been fully scrutinised, and when the whole body of information has been classified and digested, the philosophic historian will be able to formulate, with a fair degree of probability, those general laws which have shaped the intellectual, social, and moral evolution of mankind.

That will not be done in our day. The great thinkers, the Newtons and Darwins of anthropology, will come after us. It is our business to prepare for them by collecting, sifting, and arranging the records in order that when, in the fulness of time, the master-mind shall arise and survey them, he may be able to detect at once that unity in multiplicity, that universal in the particulars, which has escaped us. The duty at present incumbent on the investigator is therefore to rake together the facts, whether, like some of my friends, he goes for them at the peril of his life to savage lands, 
or merely unearths them at his ease from the dust of libraries. The time has gone by when dreamers like Rousseau could reconstruct the history of society out of their own minds, and their dreams could be accepted as visions of a golden age to come, their voices listened to like angel trumpets heralding the advent of a new heaven and a new earth. It is not for the anthropologist of to-day to blow these high notes, to build these gay castles in the clouds. His task is the soberer, duller one of laying, in the patient accumulation of facts, the foundations of a structure more solid and enduring than the glittering fantasies of Rousseau's dream. Yet he too may prove in the end to be a pioneer of revolution, a revolution all the surer and more lasting because it will be slow and peaceful.

Thus the method of anthropology is induction, and at present its students are engaged in compiling and arranging their materials rather than in evolving general theories out of them. Yet a certain amount of preliminary generalisation is legitimate and indeed necessary. The work even of observation can hardly be accomplished without some intermixture of theory to direct the observer's attention to points which he might otherwise overlook or regard as too insignificant to be worthy of record. But these provisional hypotheses should be held very loosely; we must always be ready to modify or discard them when they are found to conflict with fresh evidence. The advance of knowledge in this, as in every other field, consists in a progressive readjustment of theory to fact, of con- 
ception to perception, of thought to experience; and as that readjustment, though more and more exact, can never be perfect, the advance is infinite.

These considerations may serve to justify or at least excuse two features of anthropological books of the present day which are apt to repel students who might otherwise be attracted to the subject. One of these features is the apparently disproportionate space occupied by the bare description and cataloguing of facts, which soon pall on the reader by their number and monotony. The other is the unstable, shifting, discordant nature of the theories put forward to explain the facts. Both features are to be regretted, but they can hardly be avoided at the present stage of inquiry.

The bearing of these remarks lies, as Captain Cuttle profoundly observed, in their application. In my book I have followed the inductive method, and I intend to adhere to it in my lectures. I started without any general theory of the nature and evolution of the kingship in early society. The rule of one particular Italian kingship had long puzzled me till I happened to meet with a similar rule in southern India which seemed to throw light on the Italian custom. As soon as I began to formulate my explanation of the two, many kindred, but hitherto apparently disconnected, facts came crowding in upon me, offering, as I thought, the materials for a fairly probable induction as to certain aspects of the kingly office in early society. Thus what I at first intended to be merely an explanation of one particular kingship gradually developed into something like a 
treatise on the sanctity of the old kings in general. For my purpose it was therefore essential to enumerate and describe in detail the facts on which I based my induction, since for the most part, so far as I am aware, they had not been put together before. I shall follow the same method for the same reasons in my lectures. The principles which I shall discuss will generally be old, and may be trite to some of you. But the evidence by which I shall illustrate them will for the most part be new, by which I only mean that it has not been published before in my book. If you should find the facts which I shall inflict on you even more tedious than my theories, you will have the consolation of remembering that they are incomparably more valuable.

The particular case of a sacred kingship which served as the starting-point of my investigation was the priesthood of Diana at Nemi, which combined the regal with the sacred character; for the priest bore the title of Rex Nemorensis or King of the Wood, and his office was called a kingdom. As my general inquiry into the early kingship thus centres round Nemi, I shall invite your attention to it for a few minutes before we pass to the survey of a wider field. I shall not detain you long on what to some may be familiar ground, and I shall avoid as far as possible all repetition of what I have already published.

The Alban hills are a fine bold group of volcanic mountains which rise abruptly from the Campagna in full view of Rome, forming the last spur sent out by 
the Apennines towards the sea. Two of the extinct craters are now filled by two beautiful waters, the Alban lake and its lesser sister the lake of Nemi. Both lie far below the monastery-crowned top of Monte Cavo, the summit of the range, but yet so high above the plain that standing on the rim of the larger crater, at Castel Gandolfo, where the popes had their summer palace, you look down on the one hand into the Alban lake, and on the other away across the Campagna to where, on the western horizon, the sea flashes like a broad sheet of burnished gold in the sun.

The lake of Nemi is still, as of old, embowered in woods, where the wild flowers blow in spring as freshly as no doubt they did two thousand springs ago. It lies so deep down in the old crater that the calm surface of its clear water is seldom ruffled by the wind. On all sides but one the banks, thickly mantled with vegetation, descend steeply to the water's edge. Only on the north a stretch of flat ground intervenes between the lake and the foot of the hills. Here, under the abrupt declivity now crested by the village of Nemi, the sylvan goddess Diana had an old and famous sanctuary, the resort of pilgrims from all parts of Latium. It was known as the sacred grove of Diana Nemorensis, that is, Diana of the Wood, or perhaps more exactly, Diana of the Woodland Glade. Sometimes the lake and grove were called, after the nearest town, the lake and grove of Aricia. A spacious terrace or platform, some seven hundred feet long, contained the sanctuary. On the north and east it was bounded 
by great retaining walls which cut into the hillsides and served to support them. Semicircular niches sunk in the walls and faced with columns formed a series of chapels, which in modern times have yielded a rich harvest of votive offerings. Compared with the extent of the sacred precinct, the temple itself was not large; but its ruins prove it to have been neatly and solidly built of peperino and adorned with Doric columns. Elaborate cornices of marble and friezes of terra-cotta contributed to the outward splendour of the edifice, which appears to have been further enhanced by tiles of gilt bronze. ${ }^{1}$

The great wealth and popularity of the sanctuary in antiquity are attested by ancient writers as well as by the remains which have come to light in modern times. In the civil war its sacred treasures went to replenish the empty coffers of Octavian. ${ }^{2}$ But we are not told that he treated Diana as civilly as his uncle Julius Cæsar once treated Capitoline Jupiter, borrowing three thousand pounds weight of solid gold from the god and scrupulously paying him back in the same weight of gilt copper. ${ }^{3}$ However, the sanctuary at Nemi recovered from the drain on its resources, for two centuries later it was still reputed one of the richest in

1 On the excavation at Nemi see Nosizie degli Sravi for $1885,188 \%, 1888$. 1889, 1895; Bullesino dell Inarieupo di Corrispondenza Archédegicas, 1885. pp.

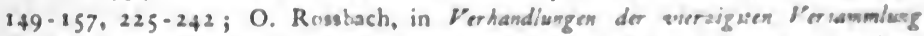
Deurseher Philologen (Leipsic, 1890), pp. 147-164; G. H. Wallie, lilusty ased Caralogue of Classical Antizuisies from the Site of the Trmple of Diana, Nomi, lialy (preface dated 1893).

\footnotetext{
2 Appian, Bellum Civile, v. 24.

Suetonius, Diews Gulius, 54 .
} 
Italy. ${ }^{1}$ Ovid has described the walls hung with fillets and commemorative tablets ${ }^{2}$ and the abundance of cheap votive offerings and copper coins, which the site has yielded in our time, speaks volumes for the piety and numbers, if not for the opulence and liberality, of the worshippers. Swarms of beggars used to stream forth daily from the slums of Aricia and take their stand on the long slope up which the labouring horses dragged well-to-do pilgrims to the shrine ; and according to the response which their whines and importunities met with they blew kisses or hissed curses after the carriages as they swept rapidly down hill again. ${ }^{3}$ Even peoples and potentates of the East did homage to the lady of the lake by setting up monuments in her sanctuary; and within the precinct stood shrines of the Egyptian goddesses Isis and Bubastis, with a store of gorgeous jewellery. ${ }^{4}$

The retirement of the spot and the beauty of the landscape naturally tempted some of the luxurious Roman nobles to fix their summer residences by the lake. Here Lucius Cæsar had a house to which, on a day in early summer, only two months after the murder of his illustrious namesake, he invited Cicero to meet the assassin Brutus. ${ }^{5} \quad$ The emperors themselves appear to have been partial to a retreat where they could find

1 Appian, loc. cit.

2 Ovid, Fasti, iii. 267 sq.

3 Juvenal, Sat. iv. 117 sq.; Persius, Sat. vi. 56 with the scholiast's note; Martial, Epigr. ii. 19. 3, xii. 32. 10.

4 W. Henzen, in Hermes, vi. (1872), pp. 6-12 ; Corpus Inscriptionum Latinarum, xiv. $2215,2216,2218$.

5 Cicero, Ad Atticum, xv. 4. 5 . 
repose from the cares of state and the bustle of the great city in the fresh air of the lake and the stillness of the woods. Here Julius Cæsar built himself a costly villa, but pulled it down again because it was not to his mind. ${ }^{1}$ Here Caligula caused two magnificent barges, or rather floating palaces, to be launched for him on the lake $;^{2}$ and it was while dallying in the woods of Nemi that the sluggard Vitellius received those tidings of revolt which woke him from his dream of pleasure and called him to arms. ${ }^{3}$ Vespasian had a monument dedicated to his honour in the grove by the senate and people of Aricia : Trajan condescended to fill the chief magistracy of the town; and Hadrian indulged in his taste for architecture by restoring a structure which had been erected in the precinct by a prince of the royal house of Parthia. ${ }^{4}$

Such, then, was the sanctuary of Diana at Nemi, a fitting home for the "mistress of mountains and forests green and lonely glades and sounding rivers," as Catullus calls her. ${ }^{5}$

Multitudes of her statuettes, appropriately clad in the short tunic and high buskins of a huntress, with the quiver slung over her shoulder, have been found on the spot. Some of them represent her with her bow in her hand or her hound at her side. Bronze and iron spears, and images of stags and hinds, discovered within the

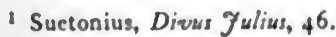

2 Norizie degli Scavi, 1895, pp. 361-396,461.474; R. Lanciani, Nirsu Taies of Old Rome (London, 1901), Pp. $205 \cdot 214$.

a Tacitus, Histor. iii. 36.

- C.I.L. xiv, 2213, 2216, 4198.

- Catullus, xxxiv. 9 s?g. 
precinct, may have been the offerings of huntsmen to the huntress goddess for success in the chase. Similarly the bronze tridents, which have come to light at Nemi, were perhaps presented by fishermen who had speared fish in the lake, or maybe by hunters who had stabbed boars in the forest. For the wild boar was still hunted in Italy down to the end of the first century of our era. The younger Pliny tells us how, with his usual pretty affectation, he sat meditating and reading by the nets, while three fine boars fell into them. ${ }^{1}$ Indeed, some fourteen hundred years later boar-hunting was a favourite pastime of Pope Leo the Tenth. ${ }^{2}$ A few rude images of cows, oxen, horses, and pigs dug up on the site may perhaps indicate that Diana was here worshipped as the patroness of domestic animals as well as of the wild creatures of the wood. In like manner her Greek counterpart, Artemis, was a goddess not only of game but of herds. Thus her sanctuary in the highlands of north-western Arcadia, between Clitor and Cynæthæ, owned sacred cattle which were driven off by Aetolian freebooters on one of their forays. ${ }^{3}$ When Xenophon returned from the wars and settled on his estate among the wooded hills and green meadows of the rich valley through which the Alpheus flows past Olympia, he dedicated to Artemis a little temple on the model of her great temple at Ephesus, surrounded it with a grove of all kinds of fruit-trees, and endowed it not only with a chase but also with a sacred pasture. The chase 
abounded in fish and game of all sorts, and the pasture sufficed to rear swine, goats, oxen, and horses ; and at her yearly festival the pious soldier sacrificed to the goddess a tithe both of the cattle from the sacred pasture and of the game from the sacred chase. ${ }^{1}$ Again, the people of Hyampolis in Phocis worshipped Artemis and thought that no cattle throve like those which they dedicated to her. ${ }^{2}$ Perhaps, then, the images of cattle found in Diana's precinct at Nemi were offered to her by herdsmen to ensure her blessing on their herds.

So to the last, in spite of a few villas peeping out here and there among the trees, Nemi seems to have remained in some sense an image of what Italy had been in the far-off days when the land was still sparsely peopled with tribes of savage hunters or wandering herdsmen, when the beechwoods and oakwoods, with their deciduous foliage, reddening in autumn and bare in winter, had not yet begun, under the hand of man, to yield to the evergreens of the south, the laurel, the olive, the cypress, and the oleander, still less to those intruders of a later age, which nowadays we are apt to think of as characteristically Italian, the lemon and the orange. ${ }^{3}$

Kennst du das Land, wo die Citronen bluhn,
Im dunkeln Laub die Gold-Orangen gluhn,
Ein sanfier Wind vom blauen Himmel weht,
Die Myrte still und boch der Lorbeer stelts?
Kennst du es wohl?

1 Xenophon, Anabasis, v. 3.4-13.

2 Pausaniae, x. 35. 7.

s. Hehn, Kubsurpflanzen und Hausshiere" (Berlin, 1902), pp. $520 \mathrm{gg}$. 
But that is modern rather than ancient Italy.

However, it was not merely in its natural surroundings that this ancient shrine of the sylvan goddess continued to be a type or miniature of the past. Down to the decline of Rome a custom was observed here which seems to transport us at once from civilisation to savagery. The priest of the goddess bore the title of king, and his office was called a kingdom, but his tenure of the throne was a singular one. He was a runaway slave, who succeeded to office by slaying his predecessor, and he held it only so long as he could make good his title in single combat against all assailants. Any fugitive slave who contrived to break a branch from a certain tree in the grove had the right to fight the priest, and if he killed him he reigned in his stead. Naturally, therefore, the priest kept watch and ward over that tree. The Greek geographer Strabo, who appears to have seen him, describes him as always sword in hand, always on the alert. ${ }^{1}$ His eyes probably acquired that restless, watchful look which, among the Esquimaux of Bering Strait, is said to betray infallibly the shedder of blood; for with that people revenge is a sacred duty, and the manslayer carries his life in his hand. ${ }^{2}$

Of the worship of Diana at Nemi there are two features of special importance which I would ask you

1 Strabo, v. 3. 12 ; Ovid, Fasti, iii. 271 sq.; id., Ars Am. i. 259 sq.; Statius, Sylv. iii. 1. 55 sq.; Suetonius, Caligula, 35 ; Solinus, ii. 11; Pausanias, ii. 27.4; Servius, on Virgil, Aen. vi. 136.

2 E. W. Nelson, "The Eskimo about Bering Strait," Eighteenth Annual Report of the Bureau of American Ethnology, Part I. (Washington, 1899), p. 293. 
to bear in mind. In the first place, the votive offerings found on the spot prove that the goddess was believed to bless men and women with offspring and to grant expectant mothers an easy delivery. ${ }^{1}$ In the second place, fire seems to have played a foremost part in her ritual. At her annual festival of the thirteenth of August her grove was illuminated, and women whose prayers had been heard by her came crowned with wreaths and bearing lighted torches to the sanctuary in fulfilment of their vows. ${ }^{2}$ Some one unknown dedicated a perpetually burning lamp in a little shrine at Nemi for the safety of the Emperor Claudius and his family. ${ }^{3}$ The terra-cotta lamps which have been discovered in the grove ${ }^{4}$ may perhaps have served a like purpose for humbler persons. If so, the analogy of the custom to the Catholic practice of dedicating holy candles in churches would be obvious.

Moreover, the title of Vesta borne by Diana at Nemi ${ }^{5}$ points clearly to the maintenance of a perpetual holy fire in her sanctuary. A large circular basement at the north-east corner of the temple, raised on three steps and bearing traces of a mosaic pavement, probably supported a round temple of Diana in her character of

'Graevius, Thesasus Antiguilasum Romanarum, xii. col. 808; Eullesino delo P Inss. de Cariap. Arch. 1885 . pp. 183 sq.; Norizie deglis Sian i, 1889. pp. 160, 254 ; id.. 1895, p. 424 ; O. Rossbach, op. sil. p. 160 ; G. H. Wallis, op. cis. Pp. 4. 15, 17.

atatius, Sjlv。 iii. 1. 92.60 ; Gratius Faliscus, Cyugrescon, i. 48487 ; Ovid, Fassi, iii. 269 s9.; Propertius, iii. 24 (30), $9 \mathrm{sg} .$, ed. Paley. As to the 13 th of August as Diana's day, see Feotus, p. 343, ed. C. O. Moller; Mastial, xii. 67. 2 ; Ausonius, De fertis Romanis, 5 sg.; C.J.L. xiv. 2112; W. Warde Fowler, Reman Forsivals of she period of the Republic, po 198.

3 Nerisie degli Scavi, 1888, ppo 193 19.; O. Rossbach, upo cis. p. 164.

- G. H. Wallis, ep. cis. pp. $24 \cdot 26$.

C.I.L. xiv. 2213 . 
Vesta, like the round temple of Vesta in the Roman forum. ${ }^{1}$ The true character of this circular basement was first perceived and pointed out by my acute and learned friend $\mathrm{Mr}$. A. B. Cook. ${ }^{2}$ Previous writers had taken it for an altar or pedestal. The sacred fire at Nemi would seem to have been tended by Vestal Virgins, for the head of a Vestal in terra-cotta was found on the spot, ${ }^{3}$ and the worship of a perpetual fire, cared for by holy maidens, appears to have been common in Latium from the earliest to the latest times. ${ }^{4}$ For example, we know that among the ruins of Alba Longa the Vestal fire was kept burning by Vestal Virgins to the end of the fourth century of our era. ${ }^{5}$

At the annual festival of Diana, which was held all over Italy on the thirteenth of August, hunting dogs were crowned and wild beasts were not molested; wine was brought forth, and the feast consisted of a kid, cakes, and apples still hanging in clusters on the boughs. ${ }^{6}$ The Christian Church appears to have sanctified this great festival of the virgin goddess by adroitly converting it into the festival of the Assumption of the Blessed Virgin on the fifteenth of August. ${ }^{7} \quad$ The discrepancy of two days between

1 Notixie degli Scavi, 1885 , p. 478 ; O. Rossbach, op. cit. p. $15^{8}$; G. H. Wallis, op. cit. pp. 9 sq.

2 Classical Review, October 1902, p. 376.

3 G. H. Wallis, op. cit. p. 30.

4 J. Marquardt, Romische Staatsverwaltung, iii. ${ }^{2} 336$.

5 Juvenal, iv. 60 sq.; Asconius, In Milonianem, p. 35, ed. Kiesseling and Schoell ; Symmachus, Epist. ix. 128 and 129 ; C.I.L. vi. 2172 , xiv. 4120.

6 Statius, Sylvae, iii. 1. 55 sq9.; Gratius Faliscus, Cynegeticon, i. 483-492.

7 J. Rendel Harris, The Ainztators of the Codex Bezae (London, 1901), pp. 93-102. 
the dates of the festivals is not a fatal argument against their identity; for a similar displacement of two days occurs in the case of St. George's festival on the twentythird of April, which is most probably identical with the ancient Roman festival of the Parilia on April twentyfirst. ${ }^{1}$ As to the reasons which prompted this conversion of the festival of the Virgin Diana into the festival of the Virgin Mary some light is thrown by the records of the Eastern Church. Thus in the Syriac text of the treatise called The Departure of my Lady Mary from this World an account is given of the reasons which led to the institution of the festival of the Assumption of the Virgin in August. In the English version of the treatise the passage runs thus : "And the apostles ordered also that there should be a commemoration of the blessed one on the thirteenth of $\mathrm{Ab}$ [that is, August: observe that the thirteenth of August is Diana's own day; another manuscript or manuscripts read on the fifteenth of $\mathrm{Ab}$, on account of the vines bearing bunches (of grapes), and on account of the trees bearing fruit, that clouds of hail, bearing stones of wrath, might not come, and the trees be broken, and their fruits, and the vines with their clusters." 2 Here you will observe that the festival of the Assumption of the Virgin is definitely said to have been fixed on the thirteenth or fifteenth of August for the sake of protecting the ripening grapes

\footnotetext{
1 The evidence for thin identification will be given in the third edition of The Golden Bough.

2 The Gow rall of Sacred Liecraswe, New Serics, vii. (1865), p. 153.
} 
and other fruits. This interesting passage was pointed out to me by my learned friend Mr. Rendel Harris. Since then I find that an inference of the same sort has been drawn independently from this passage by the late Professor Lucius of Strasburg in a book published at the end of last year, where he reinforces the argument by other evidence. ${ }^{1}$ Thus he points out that in the calendars of the Syrian Church the fifteenth of August is repeatedly designated as the Festival of the Mother of God for the vines, and that in the Arabic text of the apocryphal work On the passing of the Blessed Virgin Mary, attributed to the Apostle John, there occurs the following passage: "Also a festival in her honour was instituted on the fifteenth day of the month $\mathrm{Ab}$ [that is, August], which is the day of her passing from this world, the day on which the miracles were performed, and the time when the fruits of trees are ripening." 2 Now we hear of vineyards and plantations dedicated to Artemis, fruits offered to her, and her temple standing in an orchard. ${ }^{3}$ Hence we may conjecture that her Italian sister Diana was also revered as a patroness of vines and fruit-trees, and that on the thirteenth of August the owners of vineyards and orchards paid their respects to her at Nemi in order to ensure the safety of the ripening fruit. We have just seen that wine and

1 E. Lucius, Die Anfänge des Heiligenkults in der christlichen Kirche (Tübingen, 1904), pp. $488 \mathrm{sq.,} 52 \mathrm{r}$. The writer appears to have overlooked the occurrence of Diana's day on the $13^{\text {th }}$ of August.

2 Fohanni Apostoli de transitu Beatac Mariae Virginis Liber : ex recensione et cum interpretatione Maximiliani Engeri (Elberfeldae, 1854), pp. 101, 103.

3 Pauly - Wissowa, Real-Encyclopädie der classischen Wissenschaften, ii. 1342 ; Pausanias, vii. 18. 12 ; X enophon, Anabasis, v. 3. 12. 
apples still hanging on the boughs were part of the festal cheer on that day. We know, too, that Diana was believed to fill the husbandman's barns with a bounteous harvest, ${ }^{1}$ and in a series of gems, she is represented with a branch of fruit in one hand, and a cup, which is sometimes full of fruit, in the other. ${ }^{2}$ Even in Scandinavia a relic of the worship of Diana survived in the custom of blessing the fruits of the earth of every sort, which in Catholic times was annually observed at the festival of the Assumption of the Virgin on the fifteenth of August. ${ }^{3}$

There is, I need hardly say, no intrinsic improbability in the view that for the sake of edification the Church may have converted a real heathen festival into a nominal Christian one. My learned friend $\mathrm{Mr}$. F. C. Conybeare of Oxford has furnished me with an undoubted instance of such a transformation. He tells me that in the Armenian Church, "according to the express evidence of the Armenian fathers of the year 700 and later, the day of the Virgin was placed on September the fifteenth, because that was the day of Anahite, the magnificence of whose feast the Christian doctors hoped thereby to transfer to Mary." This Anahite or Anaitis, as the Greeks called her, the Armenian predecessor of the Virgin Mary, was a great Oriental goddess whose worship was exceedingly popular not only in Armenia but in the adjoining

1 Catullus, xxxiv. 17 ag9.

3 Furtwangler, Die ansiken Gemmen, iii. 231, with plates xx. 66, xsii. 18, 26, 30, 32, all cited by Mr. A. B. Cook, Classical Revirsw, October 1902, P. 378, note 4.

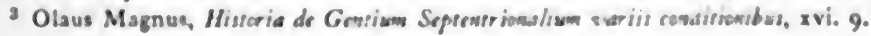


countries. The character of her rites is plainly indicated by Strabo, ${ }^{1}$ himself a native of these regions.

A mythical personage of some interest and importance at Nemi was the water-nymph Egeria. The purling of her stream as it flowed over the pebbles is mentioned by Ovid, who tells us that he had often drunk of its water. ${ }^{2}$ Women with child used to sacrifice to Egeria, because she was believed, like Diana, to be able to grant them an easy delivery. ${ }^{3}$ Tradition ran that the nymph had been the wife or mistress of the wise king Numa, that he had consorted with her in the secrecy of the sacred grove, and that the laws which he gave the Romans had been inspired by commune with her divinity. ${ }^{4}$ Plutarch compares the legend with other tales of the loves of goddesses for mortal men, such as the loves of Cybele and the Moon for the fair youths Attis and Endymion. According to some, the trysting-place of the lovers Numa and Egeria was not in the woods of Nemi, but at Rome, in a grove outside the dripping Porta Capena, where another sacred spring of Egeria gushed from a dark cavern. ${ }^{5}$ Every day the Roman Vestals

1 Strabo, xi. 8. 12, xi. 14. 16, xii. 3. 37.

2 Virgil, Aen. vii. 762 sqq.; O vid, Fasti, iii. 273 sqq.; id., Metam. xv. 482 sqq.; Strabo, v. 3. 12.

${ }^{3}$ Festus, p. 77, ed. C. O. Müller.

${ }^{4}$ Ovid, Fasti, iii. 273 sqq.; id., Metam. xv. 482 sqq.; Cicero, De legibus, i. I. 4 ; Livy, i. 19. 5, i. 21. 3 ; Plutarch, Numa, 4, 8, 13, 15; Dionysius Halicarn. Antiquit. Roman. ii. 60 sq.; Juvenal, Sat. iii. 12 ; Lactantius, Divin. Inst. i. 22 ; Servius, on Virgil, Aen. vii. 763 .

5 Juvenal, Sat. iii. 10 sqq.; Livy, i. 21. 3. As to the position of this grove and spring see O. Gilbert, Geschichte und Topographie der Stadt Rom im Altertum, i. Io9 sqq., ii. 152 sqq.; O. Richter, Topographie der Stadt Rom ${ }^{2}$ (Munich, 1902), pp. $34^{2} \mathrm{sq}$. 
fetched water from this spring to wash the temple of Vesta, carrying it in earthenware pitchers on their heads. ${ }^{1}$ In Juvenal's time the natural rock had been encased in marble, and the hallowed spot was profaned by gangs of poor Jews, who were suffered to squat, like gypsies, in the grove. We may suppose that the spring which fell into the lake of Nemi was the true original Egeria, and that when the first settlers moved down from the Alban hills to the banks of the Tiber they brought the nymph with them and found a new home for her in a grove outside the gates.

The remains of baths which have been discovered within the sacred precinct, ${ }^{2}$ together with many terracotta models of various parts of the human body, suggest that the waters of Egeria were perhaps used to heal the sick, who may have declared their hopes or testified their gratitude by dedicating likenesses of the diseased members to the goddess, in accordance with a practice which still prevails in many parts of Europe. To this day it would seem that the spring of Egeria retains medicinal virtues. ${ }^{s}$

Here I may mention a fine double bust in marble of two water-gods which has been found in the precinct at Nemi. Their heads are turned back to back. One of them is that of a bearded man, the other that of a beardless youth. Their matted hair is tossed wildly about and seems clogged with moisture; fins spring

\footnotetext{
1 Plutarch, Numb, 33 ; compare Propertius, v. 4. 15 49.; Ovid, Faste iob. 18-14.

O. Rossbach, op. cir. P. 158 ; compare C.I.L. xiv. $\$ 190$.

R. Lanciani, in Altenawm, October 10, 1885, p. 477.
} 
from their brows and from the mouth of the younger; water-plants cling to their breasts, and similar plants or fish-scales to their cheeks. Both have that wild and troubled look which the ancient artists, with their exquisite taste, loved to give to divinities of the fickle and restless element. The busts are probably the work of a skilful artist of the first century of our era. Inscriptions seem to prove that they were dedicated to Diana. ${ }^{1}$

The last of the mythical beings at Nemi to whom I have to ask your attention is Virbius. Legend had it that Virbius was no other than the young Greek hero Hippolytus whose story is familiar to you all. Two points in it must be borne in mind; first, he was the favourite of Artemis, the Greek equivalent of Diana, and second, he was killed by his horses, which dragged him at their hoofs to death. But his divine mistress, so runs the tale, had Hippolytus brought to life again, and transported him to the woods of Nemi, where she entrusted him to the nymph Egeria. There he reigned as a king under the name of Virbius, and there he dedicated a sacred precinct to his patroness Diana. $^{2}$ As to the real character of this mythical Virbius the ancients appear to have been doubtful. Some thought that he was the sun. "But the truth is," says Servius, "that he is a deity associated

I W. Helbig, in Notizie degli Scavi, 1885, p. 227 ; O. Rossbach, op. cit. p. 159; G. H. Wallis, op. cit. pp. 32 sq.

2 Virgil, Aen. vii. 761 sqg., with the commentary of Servius; Ovid, Fasti, iii. 263 sq9., vi. 735 sq9.; id., Metam. xv. 497 sqq. ; Scholiast on Persius, Sat. vi. 56, pp. 347 sq., ed. O. Jahn ; Pausanias, ii. 27. 4 ; A pollodorus, iii. 10. 3 ; Scholiast on Pindar, Pyth. iii. 96. 
with Diana, as Attis is associated with the Mother of the Gods, and Erichthonius with Minerva, and Adonis with Venus." 1 This statement of the old commentator on Virgil I believe to be of the utmost importance for the understanding both of the Arician worship in general and of the extraordinary rule of succession to the priesthood in particular. I greatly regret that in former editions of my book I missed its significance entirely. The view which it implies of the character of Virbius will form the pivot on which a good deal of our subsequent researches will revolve. Here I will only remark that in his long and chequered career this mythical personage-Hippolytus or Virbius - has displayed a remarkable tenacity of life. For we can hardly doubt that the Saint Hippolytus of the Roman calendar, who was dragged by horses to death on the thirteenth of August, Diana's own day, is no other than the Greek hero of the same name, who, after dying twice over as a heathen sinner, has been happily resuscitated as a Christian saint. ${ }^{2}$ The merit of tracing the saint's pedigree belongs to Mr. Rendel Harris, who has distinguished himself by other kindred researches in this department of sacred history. ${ }^{3}$

We can now perhaps understand why the ancients identified Hippolytus, the companion of Artemis, with Virbius, who, according to Servius, stood to Diana

1 Servius on Virgil, Aen. vii. 761.

${ }^{2}$ P. Ribadeneira, Flos Sanciorum (Venice, 1763), ii. 93 sq.; Acra . Sancrorum. August 13, pp. 4 299. (Paris and Kome, 186\%). Prudentius has drawn a picture of the imaginary martyrdom which might melt the otoniest heart (Perisegh. xi. pp. 282 sq9., ed. Th. Obbarius).

$3 \mathrm{~J}$. Rendel Harris, Annosators of Cades Bowde (London, 1901). pp. $101 \mathrm{sp}$. 
as Adonis to Venus, or Attis to Cybele. For Diana, like Artemis, appears to have been originally a goddess of fertility in general and of childbirth in particular. ${ }^{1}$ As such she, like her Greek counterpart, needed a male partner. That partner, if Servius is right, was Virbius. In his character of the founder of the sacred grove and first king of Nemi, Virbius is clearly the mythical predecessor or archetype of the line of priests who served Diana under the title of Kings of the Wood, and who came, one after the other, to a violent end. ${ }^{2}$ It is natural, therefore, to conjecture that these priestly kings stood to the goddess of the grove in the same relation in which Virbius stood to her; in short, that the mortal King of the Wood had for his queen the woodland Diana herself. ${ }^{3}$

Reviewing the evidence as a whole, we may conclude that the worship of Diana in her sacred grove at Nemi was of great importance and immemorial antiquity; that she was revered as the goddess of woodlands and of wild creatures, probably also of domestic cattle and of the fruits of the earth; that she was believed to bless men and women with offspring and to aid mothers in childbed; "that her holy fire, tended by chaste virgins, burned perpetually in a round temple within the precinct; that associated with her was a waternymph Egeria, who discharged one of Diana's own

1 See, for example, Catullus's fine poem on her (No. xxxiv.).

2 This was pointed out long ago by P. Buttmann (Mythologus, ii. 151).

3 Seneca speaks of Diana as "regina nemorum" or "Queen of the Woods" (Hippolytus, 406), perhaps with a reminiscence of the Rex Nemorensis, as Mr. A. B. Cook has suggested (Classical Review, October 1902, p. 373, n. 3). 
functions by succouring women in travail, and who was popularly supposed to have mated with an old Roman king in the sacred grove; further, that Diana of the Wood herself had a male companion, Virbius by name, who was to her what Adonis was to Venus, or Attis to Cybele; and, lastly, that this mythical Virbius was represented in historical times by a line of priests known as the Kings of the Wood, who regularly perished by the swords of their successors, and whose lives were in a manner bound up with a certain tree in the grove, because, so long as that tree was uninjured, they were safe from attack.

This ends what I have to say on Nemi for the present. In the next lecture we shall begin our study of the general principles of magic. 


\section{LECTURE II}

Priestly kings in antiquity-Relation of Spartan kings to Castor and Pollux-Incarnate gods-Kings as magicians-Principles of magic-Law of Similarity and Law of Contact-Homøopathic Magic and Contagious Magic-Both included under Sympathetic Magic - Examples of Homœopathic MagicMagical images-Cures based on Homœopathic Magic-Use of Homœopathic Magic in hunting and fishing-Negative Magic or taboo-Savage belief in magical telepathy.

$I_{N}$ the last lecture we began our consideration of the position of the king in early society. I indicated briefly that the character of sanctity which attaches to the kingship among many savage and barbarous peoples is a product of certain primitive modes of thought and of habits based on them, which are very alien to our ways of thinking and acting, and can only be understood after long and patient study. Instead of attempting to lay down a general scheme of the development of the sacred kingship in early society, I took as the starting-point of our inquiries a particular example of the institution, namely, the titular kingship of the priests of Diana at Nemi; and I think that this mode of proceeding may be justified, not only by the greater definiteness and precision which we attain by considering an abstract problem in a concrete form, but also by the many 
interesting questions which are raised by this particular kingship. In the present lecture I propose to begin the examination of these questions. They can only be adequately answered by the comparative method, and accordingly, leaving Nemi and the King of the Wood behind for the present, we must now look about for other examples of sacred kingships and try to discover the ideas on which the institution is based.

In the first place, then, we saw that the King of the Wood at Nemi, though he bore the kingly title, was, in historical times at any rate, much more a priest than a king. Now this union of priestly duties with a royal title was common in classical antiquity. Rome and Athens furnish the most familiar examples of the practice, but it existed also in many other places. In Greece the duties of these priestly kings, as we learn from Aristotle, were especially associated with the Common Hearth of the city. ${ }^{1}$ In the island of Cos, for example, the titular king sacrificed to Hestia, the goddess of the hearth, the equivalent of the Italian Vesta ; and he received the hide and one leg of the victim as his perquisite. ${ }^{2}$ In Mytilene the kings, of whom there were several, invited to banquets at the Common Hearth those guests whom the state delighted to honour. ${ }^{3}$ In Chios also there were several kings, and if any herdsman or shepherd drove his cows, his sheep, or his swine to pasture in a sacred grove, the first person

1 Aristotle, Polisiss, viii. (vi.) 8. 20, p. 1322 b 26 \$q.

2 Ditteaberger, Sylloge Inscriprionum Graecarum, ${ }^{2}$ No. 616; Ch. Michel, Recweil a'Inscriprions Grecques, No. 716.

3 Cb. Michel, Recueil, Nos. 356, 357. 
who witnessed the transgression was bound to denounce the transgressor to the kings, under pain of incurring the divine wrath and, what perhaps was more serious, of having to pay a fine to the offended deity. ${ }^{1}$ In the same island the king was charged with the duty of pronouncing the public curses, ${ }^{2}$ a spiritual weapon of which much use was made by the ancients. For example, in Teos, public curses were levelled at any one who should prevent the importation of corn into the country. "If any man," so ran the curse, "shall by any manner of means prevent the importation of corn into the land of the Teans, may he perish, he and his family." 3 But that, I need hardly inform you, was in the dark ages, before the invention of tariff reform. The Teans, it is obvious, were "free-fooders."

You will observe that all these titular kings whom I have mentioned held office in republican states. The general opinion of the ancients seems to have been that such priestly kingships were instituted after the abolition of the monarchy in order to offer the sacrifices and to discharge the religious duties which had formerly fallen within the province of the real king. The view is not improbable in itself, and it is moreover confirmed by a case in which the descendants of the old kings are known as a matter of history to have retained a shadowy

1 Dittenberger, Sylloge, ${ }^{2}$ No. 570 ; Ch. Michel, Recueil, No. 707.

2 P. Cauer, Delectus Inscriptionum Graecarum, ${ }^{2}$ No. $49^{6}$; Ch. Michel, Recueil, No. 1383.

${ }^{3}$ P. Cauer, op. cit. No. 480 ; Ch. Michel, op. cit. No. 1318.

4 Aristotle, Politics, iii. 14. 13, p. 1285 b 14 sqq.; Demosthenes, Contra Neaer. $\$ \$ 74$ sqq. p. 1370 ; Plutarch, Quaest. Rom. 63 ; Livy, ii. 2. I; Dionysius Halicarn. Antiquit. Rom. iv. 74. 4. 
royalty after the real power had departed from them. At Ephesus the descendants of the Ionian kings, who traced their pedigree to Codrus, king of Athens, kept the title of king and certain privileges, such as the right to a seat of honour at the games, to wear a purple robe and carry a staff instead of a sceptre, and to preside at the rites of Eleusinian Demeter. ${ }^{1}$ So at Cyrene, when the monarchy was abolished, the deposed King Battus was assigned certain domains and allowed to retain some priestly functions. $^{2}$

Thus the classical evidence points to the conclusion that in prehistoric ages, before the rise of the republican form of government, the various tribes or cities were ruled by kings, who discharged priestly duties and probably enjoyed a sacred character as descendants of deities. This conclusion is borne out by the example of Sparta, where the monarchy survived to historical times. For there the two kings were believed to be descended from the supreme god Zeus ; as his offspring they offered all the state sacrifices, received a share of the victims, and held the priesthood of Zeus, one of them acting as priest of Zeus Lacedæmon, the other as priest of Heavenly Zeus. ${ }^{8}$

This combination of royal authority with priestly functions is common in many parts of the world and hardly calls for illustration. To take a single example, among the Matabeles of South Africa the king is at the

Strabo, xiv. 1. 3.

2 Herodotur, iv. 162.

3 Herodotus, vi. 56 ; Xenophon, Respub. Lasedacm, 15, compare id. 13 ; Aristotle, Pelisics, iii. 14. 3. P. 128 ; a 3 มุg. 
same time high-priest. Every year he offers sacrifices at the great and the little dance, and also at the festival of the new fruits, which ends these dances. On these occasions he prays to the spirits of his forefathers and likewise to his own spirit; for it is from these higher powers that he expects every blessing. ${ }^{1}$

This example is instructive, because it shows that the king is something more than a priest. He prays not only to the spirits of his fathers, but to his own spirit. $\mathrm{He}$ is clearly raised above the common standard of mere humanity; there is something divine about him. Similarly, we may suppose that the Spartan kings were regarded not merely as descended from the great god Zeus but also as partaking of his divine spirit. This is clearly indicated by a curious Spartan belief mentioned by Herodotus, to which I do not remember that attention has been paid by modern writers. The old historian tells us that formerly both the Spartan kings went forth with the army to battle, but that in later times a rule was made that when one king marched out to fight, the other should stay at home. "And accordingly," says Herodotus, "one of the kings remaining at home, one of the Tyndarids is left there too; for hitherto both of them were invoked and followed the kings." 2 The Tyndarids, I need hardly say, are the heavenly twins, Castor and Pollux, the sons of Zeus. The belief described by Herodotus clearly

1 Father Croonenberghs, "La Mission du Zambèze," Missions Catholiques, xiv. (1882), p. 453.

2 Herodotus, v. 75 . 
implies that one of these divine beings was supposed to be in constant attendance on each of the two Spartan kings, staying with them where they stayed and going with them wherever they went. From this we may reasonably infer that they were thought to aid the kings, their kinsmen, with their advice and counsel in time of need. Now Castor and Pollux are commonly represented as spearmen, and they were constantly associated or identified, not only with stars, but also with those lurid lights which, in an atmosphere charged with electricity, are sometimes seen to play round the mastheads of ships under a murky sky. Moreover, similar lights were observed by the ancients to glitter in the darkness on the points of spears. Pliny tells us that he had seen such lights flickering on the spears of Roman sentinels as they paced their rounds by night in front of the camp ; ${ }^{1}$ and it is said that Cossacks, riding across the steppes on stormy nights, perceive glimmerings of the same sort at their lance-heads. ${ }^{2}$ Since, therefore, the divine brothers Castor and Pollux were believed to be in constant attendance on the Spartan kings, it seems not impossible that they may have been thought to accompany the march of a Spartan army, appearing in the twilight or in the darkness either as stars in the sky or as the sheen of spears on earth. It might further be worth while to consider how far the stories of the appearance of the heavenly twins in battle, charging on their milk-white steeds at the head of the

1 Pliny, Nat. Hist, ii. 101. Compare Seneca, Euaesi. Natur. i. 1. 14.

2 Potocki, Voyages dars les steps d" Astrakian of du Coucsse, i. 143. 
earthly chivalry, may not have originated in similar lights seen to glitter in the gloaming on a point here and there in the long hedge of levelled or ported spears. I mean that any two riders on white horses whose spear-heads happened to be touched by the mystic light might easily be taken for Castor and Pollux in person. If there is any truth in this conjecture-and it is only a conjecture-we should conclude that the divine brothers were never seen in broad day, but only at dusk or in the darkness of night. Now their most famous appearance was at the battle of Lake Regillus, as to which we are expressly told that it was late in the evening of a summer day before the fighting was over. ${ }^{1}$ Such statements ought not lightly to be dismissed as late inventions of a rhetorical historian. The memories of great battles linger long among the peasantry of the neighbourhood.

However that may be, the evidence of Herodotus suffices to prove that an intimate relation was believed to exist between the two Spartan kings and the divine twins Castor and Pollux. And in general there is no doubt that in early society kings have been often thought to be not merely descendants of divinities, but themselves divine and invested with supernatural powers. Thus they are frequently expected to give rain and sunshine in due season, to make the crops grow, and so forth. In short, they are considered and treated as incarnate gods. In early society the divinity that doth hedge a king is no mere figure of speech.

1 Dionysius Halicarn. Ant. Rom. vi. 13 ; Cicero, De natura deorum, ii. 2. 6. 
Of these incarnate human gods it is convenient to distinguish two types. In the one type the indwelling divinity is conceived as a spirit which has taken up its abode in the man, whether at birth or at a later time; in the other type it consists essentially in the possession of magical powers of a very high order. Accordingly the one may be called the inspired, the other the magical man-god. Strictly perhaps, according to our notions, the inspired type alone is entitled to rank as a god, while the other is merely a glorified magician. But such sharp distinctions are not drawn by primitive man. To him the two conceptions shade off into each other; perhaps he might find it hard to define or even perceive the difference between them. Certainly it would not be easy to refer all particular instances definitely to one or other of these heads. I shall therefore not attempt to carry the distinction through. But so far as we can theoretically draw a line of demarcation between them, it appears to be probable that the magical is older than the inspired type. For a consideration both of abstract probability and of the concrete facts points strongly to the conclusion that a belief in magic is older than a belief in gods. On the particular grounds for that conclusion I do not propose to dwell; an examination of them would lead us too far from our subject. But if it be true that in the evolution of society magic has preceded religion, it becomes probable that magicians may in some cases have gradually developed into kings before it occurred to people to imagine that their rulers were the living incarnations of great spirits or deities. 
However, for our immediate purpose the question of the priority of the two types is of little moment, and I shall pass it by. What is essential to the understanding of the character of kings in early society is some acquaintance with the principles of primitive magic, and some notion of the extraordinary hold which that ancient system of superstition has had on the human mind in all ages and in all countries. For whatever else he may have been, the old king seems commonly to have been a magician.

The idea that the first king was simply the strongest and bravest man of his tribe is one of those facile theories which the arm-chair philosopher concocts with his feet on the fender without taking the trouble to consult the facts. Like many other speculations of that sort it seems so obvious, so consonant to reason, that it must be true, and that to seek to establish it by actual instances would be superfluous. That such instances may occur, I would not deny; but I believe that, if we could scrutinise the whole evidence, they would be found to be the exceptions rather than the rule. All purely rationalistic speculations of this sort as to the origin of society are vitiated by one fundamental defect : they do not reckon with the influence of superstition, which pervades the life of the savage and has contributed to build up the social organism to an incalculable extent. We are only beginning dimly to apprehend how many institutions of universal prevalence, not limited to one race or one religion, may perhaps rest historically on a foundation of savage 
superstition, that is, on ideas which would now only need to be stated in order to be immediately rejected as false and absurd by every reasonable and educated man, whatever his political or religious creed might be. I say that we are only beginning to apprehend this, for we are only beginning to understand the mind of the savage, and therefore the mind of our savage forefathers who created these institutions and handed them down to us. If the time should ever come when what we merely suspect should prove to be true, and the truth should be recognised by all, it may involve a reconstruction of society such as we can hardly dream of. But that is a question for the future, perhaps a stormy future. Here we are concerned with the peaceful past.

I was led into making these remarks by the observation that it is impossible to understand the rise of the kingly power without some acquaintance with primitive superstition, and particularly with that branch of it which goes by the name of magic. Accordingly I propose now to devote some time to a consideration of the theory and practice of magic without special reference to the exercise of that art by the early king.

The principles of thought on which magic is based appear to resolve themselves into two: first, that like produces like, or that an effect resembles its cause ; and, second, that things which have once been in contact continue to act on each other even after the contact has been severed. The former principle may be called the Law of Similarity, the latter the Law of Contact or 
Contagion. From the first of these principles-namely, the Law of Similarity-the magician infers that he can produce any effect he desires merely by imitating it: from the second-namely, the Law of Contact or Contagion-he concludes that whatever he does to a material object will affect equally the person with whom the object was once in contact, whether it formed part of his body or not. Charms based on the Law of Similarity may be called Homœopathic or Imitative Magic. Charms based on the Law of Contact or Contagion may be called Contagious Magic. The expression Homœopathic Magic to designate the former species was first employed, so far as I am aware, by Mr. Y. Hirn. ${ }^{1}$ It seems to me an excellent expression, and I prefer it to the phrase Imitative or Mimetic Magic which, partly following Mr. Sidney Hartland, ${ }^{2}$ I formerly employed to denote the same thing. For Imitative or Mimetic Magic suggests, if it does not imply, a conscious agent who imitates, and it thereby limits the scope of magic too narrowly. For the same principles which the magician applies in the practice of his art are implicitly believed by him to regulate the operations of inanimate nature; in other words, he tacitly assumes that the Laws of Similarity and Contact are of universal application and are not limited to human actions. In short, magic is a spurious system of natural law as well as a fallacious guide of conduct, a false science as well as an abortive art. Regarded as 
a system of natural law, that is, as a statement of the rules which determine the sequence of events throughout the world, it may be called Theoretical Magic: regarded as a set of precepts which human beings observe in order to compass their ends, it may be called Practical Magic.

I shall return to this distinction later on. Here what I wish to impress on you is not so much the difference between the theory and the practice of magic as the distinction between the principles of thought that respectively underlie the two branches of magic which I have called Homœopathic and Contagious. Both principles turn out on analysis to be merely two different misapplications of the association of ideas. Homœopathic magic is founded on the association of ideas by similarity: contagious magic is founded on the association of ideas by contiguity. Homœopathic magic commits the mistake of assuming that things which resemble each other are the same: contagious magic commits the mistake of assuming that things which have once been in contact with each other are always in contact. But in practice the two branches of magic are often combined; or, to be more exact, while homœopathic or imitative magic may be practised by itself, contagious magic will generally be found to involve an application of the homœopathic or imitative principle. Thus abstractly stated, the two things may be a little difficult to grasp. You will readily understand them when they are illustrated by concrete examples. Both trains of thought are in fact 
extremely simple and elementary. It could hardly be otherwise, since they are familiar in the concrete, though certainly not in the abstract, to the crude intelligence not only of the savage, but of ignorant and dull-witted people everywhere. Both branches of magic, the homœopathic and the contagious, may conveniently be comprehended under the general name of Sympathetic Magic, since both assume that things act on each other at a distance through a secret sympathy, the impulse being transmitted from the one to the other by means of what we may conceive as a sort of invisible ether, not unlike that which, I understand, is postulated by modern science for a precisely similar purpose-namely, to explain how things can physically affect each other through a space which appears to be empty.

All this will, I hope, be made plain to you by the examples with which I will now illustrate both branches of magic, beginning with the homœopathic. But here it may be convenient to tabulate as follows the branches of magic according to the laws of thought which underlie them :-

(Law of Sympathy)

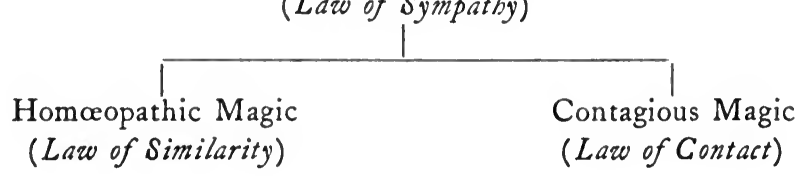

We now take up Homœopathic or Imitative Magic. Perhaps the most familiar application of the idea 
that like produces like is the attempt which has been made in many ages and in almost all parts of the world to injure or destroy an enemy by injuring or destroying an effigy of him, in the belief that just as the effigy suffers so does the man, and that when it perishes he must die. Thus the North American Indians believe that by drawing the figure of a person in sand, ashes, or clay, or by considering any object as his body, and then stabbing it with a sharp stick or doing it any other injury, they inflict a corresponding injury on the person represented. ${ }^{1}$ Among the Chippeway Indians, when a man was ill he used to ask the sorcerer to transfer the disease to some other person to whom he bore a grudge. To effect this, the sorcerer made a small wooden image of the patient's enemy, pierced the heart of the image, and introduced various magical powders into it, while he muttered an appropriate spell.2 So when a Cora Indian of Mexico wishes to kill a man, he makes a figure of him out of burnt clay, strips of cloth, and so forth, and then, uttering incantations, runs thorns through the head or stomach of the figure to make his victim suffer in the corresponding part of his body. Sometimes the Cora Indian makes a more beneficent use of this sort of homæopathic magic. When he wishes to multiply his flocks or herds, he makes a figure of the animal he wants in wax or clay, and deposits it in a cave of the mountains; for these Indians believe that the mountains

\footnotetext{
$1 \mathrm{~J}$. Morse, Repert so the Secretary of Wor of the U.S. en Indian Affairs (Newhaven, 1822), Appendix, p. 102.

W. H. Keating, Narrative of an Expedition to the Scurce of Si. Peser's River, ii. 159.
} 
are masters of all riches, including cattle and sheep. For every cow, deer, dog, or hen he wants, the Indian has to sacrifice a corresponding image of the creature. ${ }^{1}$ This may help us to understand the meaning of the figures of cattle, deer, horses, and pigs which were dedicated to Diana at Nemi. They may have been the offerings of farmers or huntsmen who hoped thereby to multiply the cattle or the game. The Peruvian Indians moulded images of fat mixed with grain to imitate the persons whom they disliked or feared, and then burned the effigy on the road where the intended victim was to pass. This they called burning his soul. But they drew a delicate distinction between the kinds of materials to be used in the manufacture of these images, according as the intended victim was an Indian or a Viracocha, that is, a Spaniard. To kill an Indian they employed maize and the fat of a llama, to kill a Spaniard they used wheat and the fat of a pig, because Viracochas did not eat llamas, and preferred wheat to maize. $^{2}$

I may observe in passing that the meaning and origin of the name Viracocha, as applied by the Peruvian Indians to the Spaniards, is explained with great frankness by an early Italian (not, you will observe, a Spanish) historian of America, who had himself travelled in the country at the time of the Conquest. He says : "When the Indians saw the very great cruelties which the Spaniards committed everywhere on entering Peru, not

I C. Lumholz, Unknown Mexico (London, 1903), i. 485 sq.

2 P. J. de Arriaga, Extirpacion de la Idolatria del Piru (Lima, 162 r), pp. 25 sq. 
only would they never believe us to be Christians and children of God, as boasted, but not even that we were born on this earth, or generated by a man and born of a woman; so fierce an animal they concluded must be the offspring of the sea, and therefore they called us $V$ iracocchie, for in their language they call the sea cocchie and the froth vira; thus they think that we are a congelation of the sea, and have been nourished by the froth; and that we are come to destroy the world, with other things in which the Omnipotence of God would not suffice to undeceive them. They say that the winds ruin houses and break down trees, and the fire burns them; but the Viracocchie devour everything, they consume the very earth, they force the rivers, they are never quiet, they never rest, they are always rushing about, sometimes in one direction and sometimes in the other, seeking for gold and silver; yet never contented, they game it away, they make war, they kill each other, they rob, they swear, they are renegades, they never speak the truth, and they deprive us of our support. Finally, the Indians curse the sea for having cast such very wicked and harsh beings on the land." 1 An explanation of the name Viracocha, much more flattering to Spanish vanity, is given by the Inca Garcilasso de la Vega, himself half a Spaniard. ${ }^{2}$ But to return to our magic.

When the Lerons of Borneo wish to be revenged on

1 G. Benzoni, History of the Newu World, pp. 252 sq. (Hakluyt Socicty).

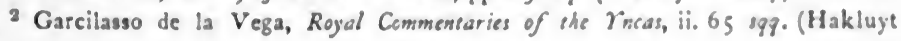
Society). 
an enemy they make a wooden image of him and leave it in the jungle. As it decays he dies. ${ }^{1}$ More elaborate is the proceeding adopted by the Kenyahs of Borneo in similar circumstances. The operator retires with the image to a quiet spot on the river bank, and when a hawk appears in a certain part of the sky he kills a fowl, smears its blood on the image, and puts a bit of fat in the mouth of the figure, saying, "Put fat in his mouth." By that he means, "May his head be cut off, hung up in an enemy's house, and fed with fat in the usual way." Then he strikes at the breast of the image with a small wooden spear, throws it into a pool of water reddened with red earth, and afterwards takes it out and buries it in the ground. ${ }^{2}$ If an Aino of Japan wishes to compass the destruction of an enemy, he will make a likeness of him out of mugwort or the guelder-rose and bury it in a hole upside down or under the trunk of a rotten tree, with a prayer to a demon to carry off the man's soul or to make his body rot away with the tree. Sometimes an Aino woman will attempt to get rid of her husband in this fashion by wrapping up his headdress in the shape of a corpse and burying it deep in the ground, while she breathes a prayer that her husband may rot and die with the head-dress. ${ }^{3}$

Often, however, magical images are employed for more amiable purposes. Thus to shoot an arrow into

\footnotetext{
3 W. H. Furness, The Home-life of Borneo Head-hunters (Philadelphia, 1902), p. 93 .

${ }^{2}$ Hose and $M$ 'Dougall, in Fournal of the Anthropolorical Institute, xxx. (1901), p. 178.

${ }^{3} \mathrm{~J}$. Batchelor, The Ainu and their Folk-lore (London, 1901), pp. 329-331.
} 
the heart of a clay image was an ancient Hindoo mode of winning a woman's love; only the bow-string must be of hemp, the shaft of the arrow must be of black ala wood, its plume an owl's feather, and its barb a thorn. ${ }^{1}$ No doubt the wound inflicted on the heart of the clay image was supposed to make a corresponding impression on the woman's heart. Among the Chippeway Indians, we are told, there used to be few young men or women who had not little images of the persons whose love they wished to win. They punctured the hearts of the images and inserted magical powders in the punctures, while they addressed the images by the names of the persons whom they represented, bidding them requite their affection. ${ }^{2}$ And as the wound of love may be inflicted by means of an image, so by means of an image it may be healed. How that can be done has been described by Heine in a poem based on the experience of one of his own schoolfellows. It is called The Pilgrimage to Kevlanr, and tells how sick people are wont to offer wax models of their ailing members to the Virgin Mary at Kevlaar in order that she may heal them of their infirmities. In Heine's poem a young man lies wasting away for love and sorrow at the death of his sweetheart. So he goes with his mother on pilgrimage to the Virgin at Kevlaar, and offers her the waxen model of a heart, with a prayer that she would be pleased to heal his own wounded

1 W. Caland, Altindisches Zauberritual (Amsterdam, 1900), P. 189 ; M. Bloom. field, Hymms of the Asharva-Veda (Oxford, 1897), pp. 358 sy.

2 W. H. Keating, Expedision so the Source of St. Peser's River, ii. 159. 
heart. Such customs, still commonly observed in some parts of Europe, are interesting because they show how in later times magic comes to be incorporated with religion. The moulding of wax images of ailing members is in its origin purely magical : the prayer to the Virgin or to a saint is purely religious : the combination of the two is a crude, if pathetic, attempt to turn both magic and religion to account for the benefit of the sufferer.

The natives of New Caledonia make use of effigies to maintain or restore harmony between husband and wife. Two spindle-shaped bundles, one representing the man and the other the woman, are tied firmly together to symbolise and ensure the amity of the couple. They are made up of various plants, together with some threads from the woman's girdle and a piece of the man's apron; a bone needle forms the axis of each. The talisman is meant to render the union of the spouses indissoluble, and is carefully treasured by them both. If, nevertheless, a domestic jar should unfortunately take place, the husband repairs to the family burying-ground with the precious packet. There he lights a fire with a wood of a particular kind, fumigates the talisman, sprinkles it with water from a prescribed source, waves it round his head, and then stirring the needle in the bundle which represents himself, he says, "I change the heart of this woman that she may love me." If the wife still remains obdurate, he ties a sugar-cane to the bundle, and presents it to her through a third person. If she eats of the sugar-cane, she feels 
her love for her husband revive. On her side she has the right to operate in like manner on the bundle which represents herself in order to recover her husband's affection. ${ }^{1}$

Another beneficent use of homœopathic magic is to heal or prevent sickness. In ancient Greece, when a man died of dropsy, his children were made to sit with their feet in water until the body was burned. This was supposed to prevent the watery disease from attacking them. ${ }^{2}$ Similarly, on the principle of water to water, among the natives of the hills near Rajamahall in India, the body of a person who has died of dropsy is thrown into a river : they think that if the corpse were buried, the disorder would return and carry off other people. ${ }^{3}$

The ancient Hindoos performed an elaborate ceremony, based on homœopathic magic, for the cure of jaundice. Its main drift was to banish the yellow colour to yellow creatures and yellow things, such as the sun, to which it properly belongs, and to procure for the patient a healthy red colour from a living, vigorous source, namely a red bull. With this intention, a priest recited the following spell: "Up to the sun shall go thy heart-ache and thy jaundice: in the colour of the red bull do we envelop thee! We envelop thee in red tints, unto long life. May this person go unscathed and be free of yellow colour!

${ }^{2}$ Father Lambert, in Missions Casholigues, xii. (1880), p. 4l; id., Marurs of Superssisions des Néo-Calédoniens (Nouméa, 1900), pp. 97 sq.

2 Plutarch, De sera numinis vindicta 14.

3 Th. Shaw, "The Inhabitants of the Hills near Rajamahall," driasic Researches, iv. 69 (8vo edition, London, 1807 ). 
The cows whose divinity is Rohini, they who, moreover, are themselves red (rohinih) -in their every form and every strength we do envelop thee. Into the parrots, into the thrush, do we put thy jaundice, and, furthermore, into the yellow wagtail do we put thy jaundice." While he uttered these words, the priest, in order to infuse the rosy hue of health into the sallow patient, gave him water to sip which was mixed with the hair of a red bull: he poured water over the animal's back and made the sick man drink it: he seated him on the skin of a red bull and tied a piece of the skin to him. Then in order to improve his colour by thoroughly eradicating the yellow taint, he proceeded thus. He first daubed him from head to foot with a yellow porridge made of turmeric or curcuma (a yellow plant), set him on a bed, tied three yellow birds, to wit, a parrot, a thrush, and a yellow wagtail, by means of a yellow string to the foot of the bed; then pouring water over the patient, he washed off the yellow porridge, and with it no doubt the jaundice, from him to the yellow birds. After that, by way of giving a final bloom to his complexion, he took some hairs of a red bull, wrapt them in gold leaf, and glued them to the patient's skin. ${ }^{1}$ The ancient Greeks held that if a person suffering from jaundice looked sharply at a stone-curlew, and the bird looked steadily at him, he was cured of the disease. "Such is the nature," says Plutarch, "and such the temperament of the creature that it draws out and

1 M. Bloomfield, Hymns of the Atharva-Veda (Oxford, 1897), pp. 7 sq., 263 sq.; W. Caland, Altindisches Zauberritual (Amsterdam, 1900), pp. 75 sq. 
receives the malady which issues, like a stream, through the eyesight." 1 So well recognised among bird-fanciers was this valuable property of the stone-curlew that when they had one of these birds for sale they kept it carefully covered, lest a jaundiced person should look at it and be cured for nothing. ${ }^{2}$ The virtue of the bird lay not in the drab colour of its plumage but in its large golden eye, which, if it is not mistaken for a tuft of yellow lichen, is the first thing that strikes the searcher, as the bird cowers, to escape observation, on the ground. ${ }^{3}$ Thus the yellow eye of the bird drew out the yellow jaundice. Pliny tells of another, or perhaps the same, bird, to which the Greeks gave their name for jaundice, because if a jaundiced man saw it the disease left him and slew the bird. ${ }^{4} \mathrm{He}$ mentions also a stone which was supposed to cure jaundice because its hue resembled that of a jaundiced skin. ${ }^{5}$ In Germany yellow turnips, gold coins, gold rings, saffron, and other yellow things are still esteemed remedies for jaundice, just as a stick of red sealing-wax carried on the person cures the red eruption popularly known as St. Anthony's fire, or the blood-stone with its blood-red spots allays bleeding. ${ }^{\circ}$ Another cure prescribed in Germany for St. Anthony's fire is to rub the patient with ashes from a house that

1 Plutarch, 2uacss. Corvivo. v. 7. 2, 8 sq.; Aelian, Nat. Animalium, xvii. 13.

2 Schol. on Aristophanes, Birds, 266 ; Schol. on Plato, Gorgias, p. 494 b.

2 Alfred Newton, Dictsonary of Birds, p. 129.

- Pliny, Nat. Hist. $\times \times \times .94$. The Greek name for jaundice, and for this singular bird, was ikecros.

- Nas. Hiss. xxxvii. 170.

- Leoprechting, Aus dem Lechrain (Munich, 1955), p. 92; A. Wuttke, Der dewesche Volksaberglaube, ${ }^{2} \& 477$. 
has been burned down $;^{1}$ for, on the principle of homœopathy, it is easy to see that as the fire died out in that house, so St. Anthony's fire will die out in that man.

An ancient Indian cure for a scanty crop of hair, based on the same principle, was to pour a solution of certain plants over the head of the patient; this had to be done by a doctor who was dressed in black and had eaten black food, and the ceremony must be performed in the early morning, while the stars were fading in the sky, and before the black crows had risen cawing from their nests. ${ }^{2}$ The exact virtue of these plants has unfortunately escaped our knowledge, but we can hardly doubt that they were dark and hairy; while the black clothes of the doctor, his black food, and the swarthy hue of the crows unquestionably combined to produce a crop of black hair on the patient's head. A more disagreeable means of attaining the same end is adopted by some of the tribes of Central Australia. To promote the growth of a boy's hair a man with flowing locks bites the youth's scalp as hard as he can, being urged thereto by his friends, who sit round watching him at his task, while the sufferer howls aloud with pain. ${ }^{3}$ Clearly, on the principle of capillary attraction,

1 A. Wuttke, loc. cit.

2 M. Bloomfield, Hymns of the Atharva-Veda, pp. 31,536 sq.; W. Caland, Altindisches Zauberritual, p. 103. In ancient Indian magic it is often prescribed that charms to heal sickness should be performed at the hour when the stars are vanishing in the sky. See W. Caland, $c p$. cit. pp. $85,86,88,96$. Was this in order that the ailment might vanish with the stars?

3 Spencer and Gillen, Northern Tribes of Central Australia (London, 1904), p. 352 ; id., Native Tribes of Central Australia, p. 251. 
if I may say so, he thus imparts of his own mature abundance to the scarcity of his youthful friend.

One of the great merits of homœopathic magic is that it enables the cure to be performed on the person of the doctor instead of on that of his victim, who is thus relieved of all trouble and inconvenience, while he sees his medical man writhe in anguish before him. For example, the peasants of Perche, in France, labour under the impression that a prolonged fit of vomiting is brought about by the patient's stomach becoming unhooked, as they call it, and so falling down. Accordingly, a practitioner is called in to restore the organ to its proper place. After hearing the symptoms he at once throws himself into the most horrible contortions, for the purpose of unhooking his own stomach. Having succeeded in the effort, he next hooks it up again in another series of contortions and grimaces, while the patient experiences a corresponding relief. Fee five francs. ${ }^{1}$

Further, great use is made of homœopathic and in general sympathetic magic for the sake of procuring a plentiful supply of food. The hunter and the fisherman resort to it for this purpose, whether their immediate object is to multiply the game and the fish, or to lure the wild creatures to their destruction. The farmer also employs it in order to cause his crops and fruits to ripen.

Thus to begin with hunting and fishing, the Toradjas of Central Celebes believe that things of the

I F. Chapiseau, Le fulk-lare de la Beuce of du P'orche (l'aris, 1902), i. 372 sq. 
same sort attract each other by means of their indwelling spirits or vital ether. Hence they hang up the jawbones of deer and wild pigs in their houses, in order that the spirits which animate these bones may draw the living creatures of the same kind into the path of the hunter. ${ }^{1}$ The western tribes of British New Guinea employ a charm to aid the hunter in spearing dugong or turtle. A small beetle, which haunts cocoa-nut trees, is placed in the socket of the spear-haft into which the spear-head fits. This is supposed to make the spear-head stick fast in the dugong or turtle, just as the beetle sticks fast to a man's skin when it bites him. ${ }^{2}$

But the system of sympathetic magic is not merely composed of positive precepts; it comprises a very large number of negative precepts, that is, prohibitions. It tells you not merely what to do, but also what to leave undone. The positive precepts are charms : the negative precepts are taboos. The whole doctrine of taboo, in fact, would seem to be only a special application of sympathetic magic, with its two great laws of similarity and contact. Though these laws are certainly not formulated in so many words by the savage, they are nevertheless implicitly believed by him to regulate the course of nature quite independently of human will. He thinks that if he acts in a certain way, certain consequences will inevitably follow in virtue of one or other of

1 A. C. Kruyt, in Verslagen en Mededeelingen der konink. Akademie van Wetenschappen, Afdeeling Letterkunde, iv. Reeks, iii. Deel (Amsterdam, 1899), pp. 203 sq.

2 B. A. Hely, "Notes on Totemism, etc., among the Western Tribes," British Nerv Guinea, Annual Report for 1894-95, p. 56 . 
these laws; and it the consequences of a particular act appear to him likely to prove disagreeable or dangerous, he is naturally careful not to act in that way in order not to incur those consequences. In other words, he abstains from doing that which, in accordance with his mistaken notions of cause and effect, he falsely believes would injure him; in short, he subjects himself to a taboo. Thus taboo is only a negative application of practical magic. Positive magic, or sorcery, says, "Do this, in order that so and so may happen." Negative magic or taboo says, "Do not do this, lest so and so should happen." Sorcery says, "Act." Taboo says, "Abstain." The aim of positive magic, that is, of sorcery, is to produce a desired event : the aim of negative magic, that is, of taboo, is to avoid an undesirable one. But both consequences, the desirable and the undesirable, are supposed to be brought about by the same natural agencies, to wit, the law of similarity and the law of contact. And just as the desired consequence is not really effected by the observance of a magical ceremony, so the dreaded consequence does not really result from the violation of a taboo. If the supposed evil necessarily followed a breach of taboo, the taboo would not be a taboo but a precept of morality or common sense. It is not a taboo to say, "Do not put your hand in the fire" ; it is a rule of common sense, because the forbidden action entails a real, not an inaginary evil. In short, those negative precepts which we call taboo are just as vain and futile as those positive precepts which we call 
sorcery. The two things are merely opposite sides or poles of one great disastrous fallacy, a mistaken conception of the nature of the association of ideas. Of that fallacy, sorcery is the positive, and taboo the negative pole. If we give the general name of magic to the whole erroneous system, both theoretical and practical, then taboo may be defined as the negative side of practical magic. To put this in a tabular form :-

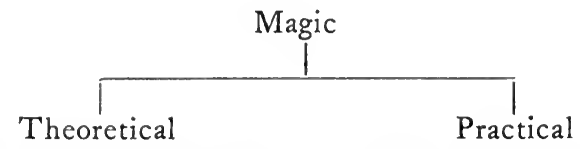

(Magic as a pseudo-science) (Magic as a pseudo-art)

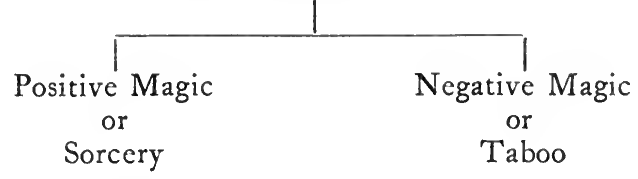

I have made these remarks on taboo and its relation to magic-a relation which has not yet, I think, been generally apprehended-because I am about to give some instances of taboos observed by hunters and fishermen, and I wished to show that they fall under the head of Sympathetic Magic, being only particular applications of that general theory.

Among the Esquimaux of Baffin Land boys are forbidden to play at cat's cradle, because if they did so their fingers might in later life become entangled in the harpoon-line. ${ }^{1}$ Here, as you will readily perceive, the taboo is obviously an application of

1 F. Boas, "The Eskimo of Baffin Land and Hudson Bay," Bulletin of the American Museum of Natural Historv, xv. Part i. (1901), p. 16r. 
the law of similarity which is the basis of homcopathic magic: as the child's fingers are entangled by the string in playing cat's cradle, so they will be entangled by the harpoon-line when he is a man and hunts whales. Again, among the Huzuls of the Carpathian Mountains, the wife of a hunter may not spin while her husband is eating; for if she does, the game will turn and wind like the spindle, and the hunter will not be able to hit it. ${ }^{1}$ Here again the taboo is clearly derived from the law of similarity. This Huzul superstition perhaps enables us to understand a curious law of ancient Italy mentioned by Pliny, which forbade women to spin on the high-roads as they walked, or even to carry their spindles openly, because any such action was believed to injure the crops. $^{2}$ Probably the notion was that the women walking on the high-road would pass fields of corn, and that the twirling of the spindle would twirl the cornstalks and prevent them from growing straight. To take another example of a taboo based on the law of similarity, that is, on homœopathic magic. Camphor is found in the form of crystals in the crevices of certain trees in the East Indies. Accordingly, in Borneo, when men are searching for camphor, they may not wash the leaves which they use as plates, lest the camphor should dissolve and disappear from the tree. $^{3}$ They think, in fact, that to wash their plates

'R. F. Kaindl, "Zauberglaube bei den Huzulen," Glohus, Ixxvi, (1899), p. 273.

"Pliny, Nar. Hiss, xxviii. 28.

2 W. H. Furness, Homs-life of Barneo Headohwerers (Philadelphia, 1902), p. 169. 
would be to wash out the camphor crystals from the trees in which they are imbedded. Again, the chief product of some parts of Laos, a province of Siam, is lac. This is a resinous gum exuded by a red insect on the young branches of trees, to which the little creatures have to be attached by hand. All who engage in the business of gathering the gum abstain from washing themselves and especially from cleansing their heads, lest by removing the parasites from their hair they should detach the other insects from the boughs. ${ }^{1}$ All these may be called homœopathic taboos. Further, some of the Brazilian Indians would never bring a slaughtered deer into their hut without first hamstringing it; for they believed that if they did not hamstring it, they and their children would never be able to run down their enemies. ${ }^{2}$ Apparently they thought that by hamstringing the animal they at the same stroke deprived their foes of the use of their legs. Once more, the Cholones, an Indian tribe of Eastern Peru, employ poisoned arrows in the chase; but there are certain animals, such as armadillos, certain kinds of falcons, and a species of vulture, which they would on no account shoot at with these weapons. For they believe that between the poisoned arrows which they use and the supply of poison at home there exists a sympathetic relation of

${ }^{1}$ E. Aymonier, Voyage dans le Laos (Paris, 1895-97), i. 322 ; compare id., Notes sur le Laos (Saigon, 1885), p. 110.

2 A. Thevet, Les singularitez de la France Antarctique, autrement nommée Amerique (Antwerp, 1558), p. 93; id., Cosmorraphie Universelle (Paris, 1575), ii. 970 [wrongly numbered, 936] sq. 
such a sort that if they shot at any of these creatures with poisoned shafts all the poison at home would be spoilt, which would be a great loss to them. ${ }^{1}$ Here the exact train of thought is not clear; but we may suppose that the animals in question are believed to possess a power of counteracting and annulling the effect of the poison, and that consequently if they are touched by it, all the poison, including the store of it at home, would be deprived of its virtue. However that may be, it is plain that the superstition rests on the law of contact, on the idea, namely, that things which have once been in contact with each other remain so sympathetically always. The poison with which the hunter wounds an animal has once been in contact with the store of poison at home; hence if the poison in the wound loses its venom, so necessarily will all the poison at home. These may be called contagious taboos.

This belief of the Cholones Indians, in the sympathetic influence exerted on each other by things at a distance, is of the essence of magic. Whatever doubts science may entertain as to the possibility of action at a distance, magic has none ; faith in telepathy is one of its first principles. A modern advocate of the influence of mind upon mind at a distance would have no difficulty in convincing a savage; the savage believed in it long ago, and what is more, he acted on his belief with a logical consistency such as his civilised brother in the faith has not yet, so far as I am aware, exhibited in his

1 E. Poeppiz, Reise in Chile, Poru und auf dem Amanonserame (Leipsic, 1835-36), ii. 323 . 
conduct. For the savage is convinced not only that magical ceremonies affect persons and things afar off, but that the simplest acts of daily life may in certain circumstances do so also. Hence on momentous occasions the conduct of friends and relations at a distance is often regulated by a more or less elaborate code of rules, the neglect of which by the one set of persons would, it is supposed, entail misfortune or even death on their distant friends. Thus, for example, when a party of men are out hunting or fighting, their relations at home are often expected to do certain things, or to abstain from doing certain others, for the sake of ensuring the safety and success of the absent hunters or warriors. How the particular acts or abstinences are supposed to operate is not always plain; what is clear is that they are really believed to affect the distant persons for good or evil.

Thus to take a few instances. When some of the Central Esquimaux are away hunting on the ice, it is forbidden to lift up the bedding at home; because they think that to do so would cause the ice to crack and drift off, and so the men might be lost. ${ }^{1}$ The notion seems to be that the lifting of the men's bedclothes would cause the ice on which they are standing to lift also; and a skater knows that the undulation of the ice is always a sign that it is thin and may give way with him. Again, among the Esquimaux in the winter, when the new moon appears, boys must run

${ }^{1}$ F. Boas, "The Eskimo of Baffin Land and Hudson Bay," Bulletin of the American Museum of Natural History, xv. Part i. (1901), p. 149. 
out of the snow-house, take a handful of snow, and put it into the kettle. It is believed that this helps the hunter to capture the seal and to bring it home. ${ }^{1}$ Here the putting of snow in the kettle is probably regarded as a preparation for boiling something in it : it is an imitation of what will happen when the hunter comes home with his bag, and thus it helps by means of imitative magic to bring about that desired result.

Lastly, in the Baram district of Sarawak, when the men are away searching for camphor in the forest, the women at home dare not touch a comb; for if they did so, the interstices between the fibres of the tree, instead of being filled with the precious camphor crystals, would be empty, like the spaces between the teeth of a comb. ${ }^{2}$ This is plainly an application of the law of similarity; in other words, it is a case of homœopathic magic.

These examples may serve to illustrate the savage theory of telepathy, that is, the belief in a magical sympathy which binds together friends at a distance so that their actions mutually affect each other for good or ill. And in regard to negative magic or taboo the foregoing instances have shown that it, like positive magic or sorcery, falls into two great divisions, which may be called respectively Homœopathic Taboo and Contagious Taboo, according as they are based on the law of similarity or the law of contact. 


\section{LECTURE III}

Magical telepathy in war-Homœopathic Magic in relation to plants, animals, inanimate things, and the dead-Homœopathic Magic used to annul evil omens-Examples of Contagious Magic - Magical contact between a wounded person and the weapon that hurt him-Magical contact of footprints-Public magicians develop into kings-Rise of monarchy essential to the emergence of mankind from savagery.

IN the last lecture I explained the two great principles of magic, which may be called the Law of Similarity and the Law of Contact. The law of similarity is the foundation of homœopathic or imitative magic. The law of contact is the foundation of contagious magic. Both branches of magic assume the possibility of acting on persons and things at a distance. At the end of last lecture I illustrated this primitive belief in telepathy by the rules observed by people at home while their friends are away hunting or searching for precious commodities, such as camphor. Rules of the same sort, based on a belief in the sympathetic connection between persons at a distance, are observed by friends and relations at home while the men are out on the warpath. Thus among the Toradjas of Central Celebes, when a party is away hunting for heads, the villagers who stay at home, and 
especially the wives of the head-hunters, have to observe certain rules in order not to hinder the absent men at their task. In the first place the entrance to the lobo or spirit-house is shut. For the spirits of their fathers, who live in that house, are now away with the warriors, watching over and guarding them; and if any one entered their house in their absence, the spirits would hear the noise and return in great anger at thus being recalled from the campaign. Moreover, the people at home have to keep the house tidy: the sleeping-mats of the absent men must be hung on beams, not rolled up as if they were to be away for a long time : their wives and next-of-kin may not quit the house at night : every night a light burns in the house, and a fire must be kept up constantly at the foot of the house-ladder : garments, turbans, and head-dresses may not be laid aside, for if the turban or head-dress were put off by friends at home, the warrior's turban might drop from his head in the battle. When the spirit of the headhunter returns home in his sleep (which is the Toradja's expression for a soldier's dream) he must find everything there in good order and nothing that could vex him. By the observance of these rules, say the Toradjas, the souls of the head-hunters are covered or protected. And in order to make them strong, that they may not soon grow weary, rice is strewed morning and evening on the floor of the house, probably in order to feed and refresh the absent warriors. The women too go about constantly with a certain plant of which the pods are so light and feathery that they are easily 
wafted by the wind, for that helps to make the men nimble-footed. ${ }^{1}$ This last custom, as well as the rule as to the wearing of turbans, are clearly applications of the law of similarity.

Among the Shans of Burma the wife of an absent warrior has to observe certain rules. Every fifth day she rests and does no work. She fills an earthen goblet with water to the brim and puts flowers into it every day. If the water sinks, or the flowers fade, it is an omen of death. Moreover, she may not sleep in her husband's bed during his absence, but she sweeps the bedding clean and lays it out every night, ${ }^{2}$ perhaps in order that her husband's soul may repose on it if he should revisit his home in a dream, like the war-broken soldier in Campbell's poem-

Our bugles sang truce, for the night-cloud bad lower'd, And the sentinel stars set their watch in the sky.

While marriageable boys of the Mekeo district in British New Guinea are making their drums, they have to live alone in the forest and observe a number of rules which are based on the law of similarity, that is, on the principle of homœopathic magic. The drums will be used in the dances, and in order that they may give out a resonant sonorous note, great care must be taken in their construction. Having chosen a suitable piece of wood, the lad hollows out the inside by burning it with a hot coal till the sides are very thin. The skin

1 A. C. Kruyt, "Het Koppensnellen der Toradja's van Midden-Celebes, en zijne beteekenis," Verslagen en Mededeelingen der konink. Akademie van Wetenschappen, Afdeeling Letterkunde, iv. Reeks, iii. Deel (Amsterdam, 1899), pp. 258 sq.

2 Indian Antiquary, xxi. (1892), p. 120. 
of an iguana is then stretched over the hollow and tightened with string and glue. All the time the boy is at work on the drum, he may not eat fish ; for if a fish bone pricked him, the skin of the drum would burst. If he ate a red banana, it would choke him, and the drum would consequently have a dull stifled note : if he tasted grated cocoa-nut, the white ants, like the white particles of the nut, would gnaw the body of the drum : if he touched water, the hot coal with which he burns out the inside of the drum would be extinguished : if he cooked his food in an ordinary round pot, he himself would grow fat and round like a pot, and the girls would jeer at him. ${ }^{1}$ Again, a Highland witch can sink a ship by homæopathic magic. She has only to set a small round dish floating in a milk-pan full of water, and then to croon her spell. When the dish upsets in the pan, the ship will go down in the sea. They say that once three witches from Harris left home at night, after placing the milk-pan thus on the floor, and strictly charging a serving-maid to let nothing come near it. But while the girl was not looking, a duck waddled into the room and squattered in the water of the pan. Next morning the witches came home and asked if anything had come near the pan. The girl said "No," whereupon one of the witches remarked, "What a heavy sea we had last night coming round Cabag Head!"'2 If a wolf

1 Father Guis, "Les Canaques, ce qu'ils font, ce qu'ils disent," Missicns Carioliques, xxx. (1898), p. 29 ; A. C. Hadidon, Head-huvters, p. 257.

2 J. G. Campbell, Wirchcrafi and Second Sighe in the Highlands and lslands of Scopland (Glasgow, 1902), pp. 21 87. 
has carried off a sheep, the Esthonians know a very simple way of making him drop it. They let fall anything they happen to have at hand, such as a cap or a glove, or they lift up a heavy stone and let it go. ${ }^{1}$ On the principle of homœopathic magic, that clearly compels the wolf to let go the sheep.

In the last lecture I mentioned that homœopathic magic is often employed to make plants grow and bear fruit. Thus among the Huzuls of the Carpathians, when a woman is planting cabbages, she winds many cloths about her head, in order that the heads of the cabbages may also be thick. ${ }^{2}$ Among the Kurs of East Prussia, when a farmer sows his fields in spring, he carries an axe and chops the earth with it, in order that the corn-stalks may be so sturdy that an axe will be needed to hew them down. ${ }^{3}$ When Macedonian farmers have done digging their fields, they throw their spades up into the air, and catching them again, exclaim, "May the crop grow as high as the spade has gone!" 4 And as plants may be helped, so they may be hindered and marred by homœopathic magic. The eminent novelist, Mr. Thomas Hardy, was once informed that the reason why certain trees in front of his house, near Dorchester, did not thrive, was that he looked at them before breakfast on an empty stomach. Mr. Hardy

1 Boecler-Kreutzwald, Der Ehsten abergläubische Gebräuche, Weisen und Gewohnheiten, p. 122.

2 R. F. Kaindl, "Zaukerglaube bei den Huzulen," Globus, lxxvi. (1899), p. 276.

3 F. Tetzner, "Die Kuren in Ost-preussen," Glcbus, 1xxv. (1899), p. 148.

4 G. F. Abbott, Macedonian Folk-lore (Cambridge, 1903), p. 122. 
told me this himself. ${ }^{1}$ You will easily perceive that the effect of an empty stomach, conveyed through the eyesight, must necessarily be prejudicial to trees by emptying them, so to say, of sap and nutriment. Thus stated the principle seems almost a truism.

In these examples people are supposed to influence plants for good or evil by means of homœopathic magic. But on the same principle plants can reciprocally influence people. In magic, as I believe in physics, action and reaction are equal and opposite. The Cherokee Indians are adepts in practical botany of this sort. Thus the wiry roots of the catgut plant or devil's shoestring (Tephrosia) are so tough that they can almost stop a ploughshare in the furrow. Hence Cherokee women wash their heads with a decoction of the roots to make the hair strong, and Cherokee ball-players wash themselves with it to toughen their muscles. Again, to help them to spring quickly to their feet when they are thrown to the ground, these Indian ball-players bathe their limbs with a decoction of the small rush (Funcus renuis), because, so they say, that plant always recovers its erect position, no matter how often it has been trampled down. To improve a child's memory the Cherokees beat up burs in water which has been fetched from a roaring waterfall. The virtue of the potion is threefold. The voice of the Long Man or river-god is heard in the roar of the cataract: the stream seizes and holds whatever is cast upon its surface ; and there is nothing that sticks like a bur. Hence it

1 Compare Fult-lore, viii. (1897), p. 18. 
seems clear that with the potion the child will drink in the lessons taught by the voice of the waters, will seize upon them like the stream, and will stick fast to them like a bur. ${ }^{1}$

The Sundanese of the Indian Archipelago regard certain kinds of wood as unsuitable for use in housebuilding, especially such trees as have thorns on them. They think that the life of people who lived in a house made of such timber would be thorny and full of trouble. If a house were built of trees that had fallen or lost their leaves through age, the inmates would die soon; if it were built of wood taken from a house that had been burnt down, fire would be sure to break out in the new dwelling. ${ }^{2}$ Before the Cherokee braves went forth to war, the medicine-man used to give each of them a small charmed root which made him absolutely invulnerable. On the eve of battle the warrior bathed in a running stream, chewed a portion of the root and spat the juice on his body in order that the bullets might slide from his skin like the drops of water. Some of you may perhaps doubt whether this really made the men bullet-proof. There is a barren and paralysing spirit of scepticism abroad at the present day which is most deplorable. However, the efficacy of this particular charm was proved in the American Civil War; for three hundred Cherokees served in the army of the

1 J. Mooney, "Myths of the Cherokee," Nineteenth Annual Report of the Bureau of American Ethnology (Washington, 1900), Pt. i. pp. 425 sq.; compare id., "Sacred Formulas of the Cherokees," Seventh Annual Report of the Bureau of Ethnology (Washington, 1891), p. 329.

$2 \mathrm{~J}$. Habbema, "Bijgeloof in de Praenger-Regentschappen," Bijdragen tot de Taal-Land-en Volkenkunde van Nederlandsch Indie,, li. (1900), p. 113. 
South, and they were never, or hardly ever, wounded in action. ${ }^{1}$

Homœopathic magic often works by means of the dead; for just as the dead can neither see nor hear nor speak, so you can render people temporarily blind, deaf, and dumb by means of dead men's bones or anything else that is infected with the contagion of death. Burglars in all ages and in many lands have been patrons of this species of magic. In ancient Greece the housebreaker thought he could silence the fiercest watch-dog by means of a brand plucked from a funeral pyre. ${ }^{2}$ To throw the inmates of a house into deep slumber, the Peruvian Indian scatters the dust of dead men's bones." The Indians of Mexico employed for this purpose the left forearm of a dead woman; but the bone had to be stolen. With this they beat on the ground before they entered the house which they intended to rob; that made the inmates to lose all power of speech and motion; they were as dead, hearing and seeing everything, but powerless to stir. In Europe similar properties were ascribed to the Hand of Glory, which was the dried and pickled hand of a man who had been hanged. If a candle made of the fat of a malefactor who had also died on the gallows was lighted and placed in the Hand of Glory as in a

'J. Mooney, "Sacred Formulas of the Cherokees," Sruensh Annual Repert of the Burcaw of Ethmology (Washingion, 8891), p. 389.

Aclian, Nap. Anim. i. 38.

2. J. de Arriaga, Extirpacion de la ldelatria del Piru (lima, 1621 ), p. 22.

- B. de Sahagun, Histoire Genirale des shoses de la Nowerlie Eupagme (Paris, 1880), bk. iv. ch. 31, pp. 274 29.; E. Seler, Alemexikanisshe Srudien, ii. (Berlin, 8 899), pp. 31 2p. (Veröfentlichungen aus dem kiniglichem Muscum für Vaikerhawde, vi.). 
candlestick, it rendered motionless all persons to whom it was presented ; they could not stir a finger any more than if they were dead. ' Sometimes the dead man's hand is itself the candle, or rather bunch of candles, all its withered fingers being set on fire; but should one member of the household be awake, one finger of the hand will not kindle. ${ }^{2}$ When a Blackfoot Indian went out eagle-hunting, he used to take a skull with him, because he believed that the skull would make him invisible like the dead man to whom it had belonged. Thus the eagles would not be able to see and attack him. ${ }^{3}$ The Tarahumares of Mexico are great runners, and parties of them engage in races with each other. They believe that the bones of the dead induce fatigue; hence before a race the friends of one side will bury dead men's bones in the track, hoping that the runners of the other side will pass over them and so be weakened. Naturally they warn their own men to shun the spot where the bones are buried." The Belep tribe of New Caledonia think they can disable an enemy from flight by means of the leg-bone of a dead foe. They stick certain plants into the bone, and then smash it between stones before the skulls of their ancestors. It is easy to see that this breaks the leg of the living enemy and so hinders him from running away. ${ }^{5}$

1 J. Brand, Popular Antiquities of Great Britain, iii. $278 \mathrm{sq}$. (Bohn's edition).

2 W. Henderson, Folk-lore of the Northern Counties of England, pp. 239 sqq.; J. W. Wolf, Niederlandische Sagen (Leipsic, 1843), pp. 363-365.

3 G. B. Grinnell, Blackfoot Lodge Tales, p. 238.

4 C. Lumholtz, Unknown Mexico, i. 284.

5 Father Lambert, in Missions Catholiques, xi. (1879), p. 43 ; id., Maeurs et superstitions des Néo-Calédoniens (Nouméa, 1900), pp. 30 sq. 
Again, many animals are conceived to possess properties which might be useful to man, and accordingly the savage seeks to transfer them to himself by means of homœopathic magic. Thus when a Galla of East Africa sees a tortoise, he will take off his sandals and step on it, believing that this makes the soles of his feet hard like the shell of the animal. ${ }^{1}$ The Esquimaux of Baffin Land think that if part of the intestines of a fox is placed under the feet of a baby boy, he will become active and skilful in walking over thin ice, like a fox. ${ }^{2}$

The ancient Greeks were of opinion that to eat the flesh of the wakeful nightingale would prevent a man from sleeping; that to smear the eyes of a blear-sighted person with the gall of an eagle would give him the eagle's vision; and that a raven's eggs would restore the blackness of the raven to silvery hair. Only, the person who adopted this last mode of concealing the ravages of time had to be most careful to keep his mouth full of oil all the time he applied the raven's eggs to his venerable locks, else his teeth as well as his hair would be dyed raven black, and no amount of scrubbing and scouring would avail to whiten them again. ${ }^{3}$ The hair-restorer was in fact a shade too powerful, and in applying it you might get more than you bargained for.

The Huichol Indians of Mexico admire the beautiful

' Ph. Paulitschke, Eshnographie Nordost-Afrikas: die geissige Cultur der Danśkil, Galla und Somal (Berlin, 2896), p. 27.

2F. Boas, "The Eskimo of Baffin Land and Hudson Bay," Ballesin of she American Muroum of Natwal Hissory, xv. Pt. i. (2901), p. 860.

- Aelian, Nar. Anim. i. 42, 43, and 48 . 
markings on the backs of serpents. Hence when a Huichol woman is about to weave or embroider, her husband catches a large serpent and holds it in a cleft stick, while the woman strokes the reptile with one hand down the whole length of its back; then she passes the same hand over her forehead and eyes, that she may be able to work as beautiful patterns in the web as the markings on the serpent's back. ${ }^{1}$ Among the Tarahumares of Mexico men who run races tie deer-hoofs to their backs in the belief that this will make them swift-footed like the deer. ${ }^{2}$ Cherokee ball-players rub their bodies with eel-skins in order to make themselves as slippery and hard to hold as eels; and they also apply land-tortoises to their legs in the hope of making them as thick and strong as the legs of these animals. But they are careful not to eat frogs, lest the brittleness of the frog's bones should infect their own bones. They will not wear the feathers of the baldheaded buzzard for fear of themselves becoming bald, nor turkey feathers, lest they should suffer from a goitrous growth on the throat like the red appendage on the throat of a turkey. ${ }^{3}$ Again, the flesh of the common grey squirrel is forbidden to Cherokees who suffer from rheumatism, because the squirrel eats in a cramped position, which would clearly aggravate the pangs of the rheumatic patient. ${ }^{4}$

1 C. Lumholtz, Unknown Mexico, ii. 234.

$2 I d$., ib. i. 290.

3 J. Mooney, "Myths of the Cherokee," Nineteenth Annual Report of the Bureau of American Ethnology (Washington, 1900), Part i. pp. 262, 284, 285, 306, 308.

4 Id., ib. p. 262. 
When a Cherokee is starting on a journey on a cold winter morning, he rubs his feet in the ashes of the fire and sings four verses, by means of which he can set the cold at defiance, like the wolf, the deer, the fox, and the opossum, whose feet, so the Indians think, are never frost-bitten. After each verse he imitates the cry and action of the animal, thus identifying himself with it by means of homœopathic magic. The song he sings may be rendered, "I become a real wolf, a real deer, a real fox, and a real opossum." After stating that he has become a real wolf, the songster utters a prolonged howl and paws the ground like a wolf with his feet. And similarly he mimics the other animals. ${ }^{1}$ The mole-cricket has claws with which it burrows, and among the Cherokees it is reputed to be an excellent singer. Hence when children are long of learning to speak, their tongues are scratched with the claw of a live mole-cricket in order that they may soon talk as distinctly as the insect. Grown persons also who are slow of speech may acquire a ready flow of eloquence, if only the inside of their throat be scratched on four successive mornings with a molecricket. $^{2}$ The negroes of the Maroni river in Guiana have a somewhat similar cure for stammering. Day and night the shrieks of a certain species of ape resound through the forest. Hence, when the negroes kill one of these pests, they remove its larynx and make a cup out of it. If a stammering child drinks

'J. Mooney, "Mythe of the Cherokec," Nincteensh Anriwal Repors of the Burresu of American Eshoology (Washington, 8900), lart i. p. 266.

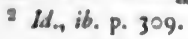


out of such a cup for a few months, it ceases to stammer. $^{1}$

Cherokee parents scratch the hands of their children with the pincers of a live red crawfish, resembling a lobster, in order to give the infants a strong grip, like that of the crawfish. ${ }^{2}$ This may help us to understand why on the fifth day after birth a Greek child used to receive presents of octopuses and cuttle-fish from its friends and relations. ${ }^{3}$ For the numerous arms, legs, and tentacles of these creatures seem well calculated to strengthen the grip of a baby's hands and to impart the power of toddling to its little feet.

On the principle of homœopathic magic inanimate things as well as plants and animals may be fraught with blessing or bane for mankind; and the wise man will extract the one or avoid the other as the case may be. Out of an infinity of cases I will cite a very few examples. Thus, on the seventh day after a birth the Toradjas hold a little feast, at which the feet of the child are set on a piece of iron, in order to strengthen its feeble soul with the strong soul of the iron. ${ }^{4}$ Similarly at initiation a Brahman boy is made to tread with his right foot on a stone, while the words are repeated, "Tread on this stone; like a stone be firm." ${ }_{5}$ A Malagese mode of counteracting the levity of fortune is to bury a stone at the foot of the heavy house-

1 J. Crevaux, Voyages dans I'Amérique du Sud (Paris, 1883), pp. 159 sq.

2 J. Mooney, op. cit. p. 308.

3 Scholiast on Plato, Theaetetus, p. 160 A.

4 A. C. Kruijt, "Het ijzer in Midden-Celebes," Bijdragen tot de Taal-Land-en Volkenkunde van Nederlandsch Indië, liii. (1901), p. 159.

- Grihya-Sitras, translated by H. Oldenberg, Part ii. p. 146. 
post. ${ }^{1}$ The common custom of swearing upon a stone may be based partly on a belief that the strength and stability of the stone lend confirmation to the oath. Thus there was a stone at Athens on which the nine archons stood when they swore to rule justly and according to the laws. ${ }^{2}$ In Laconia an unwrought stone was shown which, according to the legend, relieved the matricide Orestes of his madness as soon as he had sat down on it; ${ }^{3}$ and Zeus is said to have cured himself of his love for Hera by sitting down on a certain rock in the island of Leucadia. ${ }^{4}$ In these cases it may have been thought that the wayward and flighty impulses of love and madness were counteracted by the steadying influence of a heavy stone.

But magical virtue resides in stones by reason of their shape and colour as well as of their weight and solidity. The Indians of Peru employed certain stones for the increase of maize, others for the increase of potatoes, and others again for the increase of cattle. The stones intended to make maize grow were fashioned in the likeness of cobs of maize, and the stones destined to multiply cattle had the shape of sheep. ${ }^{5}$

This mode of agriculture is extensively practised by the natives of New Caledonia. Thus in order to make

\footnotetext{
1 Father Abinale, "Astrologie Malgache," Missions Casholiques, xi. (1879), p. 482.

${ }^{2}$ Ariatotle, Constipution of Aikens, 7 and 55; Plutarch, Solor, 25; Pollux, viii. 86 .

${ }^{3}$ Pausaniat, iii. 22. 1; compare id. ii. 31.4.

- Ptolemaeus, Nosa Historia, in Photius, Bibliorheca, p. 153, ed. Bekker; id. in Myehographi Graeci, ed. Weatermann, p. 398.

P. J. de Arriaga, Exesirpacion de la ldolatria del Piru (Lima, 1628), Pp. 15, 16,29 .
} 
a plantation of taro thrive, they bury in the field certain stones resembling taros, praying to their ancestors at the same time. A stone marked with black lines like the leaves of a cocoa-nut palm helps to produce a good crop of cocoa-nuts. To make bread-fruit grow, they use two stones, one small and one big, representing the unripe and the ripe fruit respectively. As soon as the fruit begins to form, they bury the small stone at the foot of the tree; and later on, when the fruit approaches maturity, they replace the small stone by the large one. But the staple food of the New Caledonians is the yam; hence the number of stones used to foster the growth of yams is correspondingly great. Different families have different kinds of stones which, according to their diverse shapes and colours, are supposed to promote the cultivation of the various species of yams. Before the stones are buried in the field they are deposited beside the ancestral skulls, wetted with water, and wiped with the leaves of certain trees. Sacrifices, too, of yams and fish are offered to the dead, with the words, "Here are your offerings, in order that the crop of yams may be good." I In these practices of the New Caledonians the magical efficacy of the stones appears to be deemed insufficient of itself to accomplish the end in view; it has to be reinforced by the spirits of the dead, whose help is sought by prayer and sacrifice. Thus in New Caledonia sorcery is blent with the worship of the

1 Father Lambert, Mours et superstitions des Néo-Calédoniens (Nouméa, 1900), pp. 217, 294, 300-302. 
dead; in other words, magic is combined with religion. If the stones ceased to be employed, and the prayers and sacrifices to the ancestors remained, the transition from magic to religion would be complete.

The last example I shall cite of the magical influence of things is drawn from the ancient ritual books of the Hindoos, which lay down a rule that after sunset on his marriage night a man should sit silent with his wife till the stars begin to twinkle in the sky. When the polestar appears, he should point it out to her, and, addressing the star, say, "Firm art thou; I see thee, the firm one. Firm be thou with me, $\mathrm{O}$ thriving one !" Then, turning to his wife, he should say, "To me Brihaspati has given thee; obtaining offspring through me, thy husband, live with me a hundred autumns." ' The intention of the ceremony is plainly to guard against the fickleness of fortune and the instability of earthly bliss by the steadfast influence of the constant star. It is the wish expressed in Keats's last sonnet :-

Bright star! would I were steadfast as thou artNot in lone splendour hung aloft the night.

Sometimes homœopathic or imitative magic is called in to annul an evil omen by accomplishing it in mimicry. The effect is to circumvent destiny by substituting a mock calamity for a real one. In Madagascar this mode of cheating the fates is reduced to a system.

1 The Grikyd-Satras, translated by H. Oldenberg, Part i. Pp. 43.285 8q., Part ii. PP. 47 4.. 193899. 
Here every man's fortune is determined by the day or hour of his birth, and if that happens to be an unlucky one his fate is sealed, unless the mischief can be extracted, as the phrase goes, by means of a substitute. The ways of extracting the mischief are various. For example, if a man is born on the first of February, his house will be burnt down when he comes of age. To take time by the forelock and prevent this catastrophe, the friends of the infant will set up a shed in a field and burn it. To make the ceremony really effective, the child and his mother should be placed in the shed, and only plucked, like brands, from the burning hut before it is too late. Again, dripping November is the month of tears, and he who is born in it is born to sorrow. But in order to disperse the clouds that thus gather over his future, he has nothing to do but to take the lid off a boiling pot and wave it about. The drops that fall from the lid will accomplish his destiny and so prevent the tears from trickling from his eyes. Again, if fate has decreed that a young girl should hereafter become a wife and mother, and should see her children descend before her with sorrow to the grave, she can avert the calamity as follows. She kills a grasshopper, wraps it in a rag to represent a shroud, and mourns over it like Rachel weeping for her children and refusing to be comforted. After burying the insect, she retires from the grave with the air of a person plunged in grief. Thenceforth she looks cheerfully forward to seeing her children survive her; for it cannot be that she should mourn and bury them twice 
over. Once more, if fortune has frowned on a man at his birth, and penury has marked him for her own, he can easily erase the mark in question by purchasing a couple of cheap pearls, price three half-pence, and burying them. For who but the rich of this world can thus afford to fling pearls away ? ${ }^{1}$

Thus far we have been concerned chiefly with the homœopathic or imitative branch of magic, which rests, as I have repeatedly observed, on the law of similarity. It is time to look for a few minutes at the other branch of the art - namely, Contagious Magic. The logical, or perhaps I should rather say the illogical, basis of contagious magic is the law of contact; that is, the notion that things which have once been conjoined and are afterwards separated remain nevertheless, however great the distance between them, so united by a bond of sympathy that whatever is done to the one affects the other in like manner.

A curious instance of contagious magic is the belief that between a wounded person and the weapon which inflicted the wound there exists so close a relation that whatever is done to the weapon will correspondingly affect the wounded person for good or evil. Thus in one of the tribes of South-Eastern Australia it is thought that if any one but the medicine-man touches the flint knife with which a certain surgical operation has been performed on a lad, the lad will thereby be

\footnotetext{
2W. Ellis, History of Madagascar, i. 454 399.; Father Abinal, "Astrologie Malgache," Missions Casholigues, xi. (1879), pp. $432-434,481-48$ 3.
} 
made very ill. So seriously is this belief held, that if after the operation the lad should chance to fall sick and die, the man who touched the knife would be killed. ${ }^{1}$ Beliefs of precisely the same sort are held to this day almost at our own door, in the eastern counties of England, where people still imagine that they can heal a wound by greasing the instrument which inflicted it. To take a recent example of this superstition, at Norwich in June I902 a woman named Matilda Henry accidentally ran a nail into her foot. When the nail was extracted, she did not examine the wound nor even take off her stocking, but told her daughter to grease the nail, saying that if that were done, no harm would come of the hurt. Under this treatment the nail recovered, but the woman died of lockjaw a few days afterwards. ${ }^{2}$ Similarly in Bavaria you are directed to anoint a linen rag with grease and tie it on the edge of the axe that cut you, taking care to keep the sharp edge upwards. As the grease on the axe dries, your wound heals. ${ }^{3}$

The sympathetic connexion supposed to exist between a man and the weapon which has wounded him is probably founded on the notion that the blood on the weapon continues to feel with the blood in his body. For that reason the Papuans of Tumleo, an island off German New Guinea, are careful to throw into the sea the bloody bandages with which their wounds have

1 A. W. Howitt, Native Tribes of South-East Australia (London, 1904), p. 667.

2 "Death from Lockjaw at Norwich," The People's Weekly Fournal for Norfolk, July 19, 1902, p. 8.

3 F. Panzer, Beitrag zur deutschen Mythologie, ii. 305, compare 277. 
been dressed, for fear that if these rags fell into the hands of an enemy he might bewitch them thereby. Once when a man with a wound in his mouth, which bled constantly, came to the missionaries to be treated, his faithful wife took great pains to collect all the blood and cast it into the sea. ${ }^{1}$ But the doctrine of magical contagion is stretched still further, so to include a man's clothes as well as the severed parts of himself. On this doctrine, whatever is done to the clothes is done to the man himself, and he feels the effect even though he may not be wearing the clothes at the time. That is why these same Papuans of Tumleo search most anxiously for the smallest scrap which they may have lost of their scanty garments, ${ }^{2}$ and why other Papuans, in travelling through the thick forest, will stop and carefully scrape from a bough any clot of red pomade which may have adhered to it from their greasy heads, lest a sorcerer should get possession of the rag or of the pomade and do them a mischief by means of it. ${ }^{3}$

The last example of Contagious Magic which I shall notice is the relation supposed to exist between a man and the impressions left by his body in sand or earth. In virtue of the law of contact the sand or earth which bears the imprint of your body is supposed to remain for all practical purposes an integral part of

1 M. J. Erdweg, "Die Bewohner der Insel Tumleo, Berlinhafen, Deutsch-Neu. Guinea," Mistheilungen der anshropologischen Gesellschafi in Wien, xxxii. (8902), p. 287.

2 M. J. Erdweg, loc. cir.

3. Hagen, Unter den Papua's (Wiesbaden, 1899), p. 269. 
yourself even when you are far away, so that you will feel any injury done to the imprint as if it were done to your person. In particular, it is a world-wide superstition that by injuring footprints you injure the feet that made them. Thus, the inhabitants of Galela, in the East Indies, think that if anybody sticks something sharp into your footprints while you are walking, you will be wounded in your feet. ${ }^{1}$ In Japan, if a house has been robbed by night and the burglar's footprints are visible in the morning, the injured householder will burn mugwort on them, hoping thereby to hurt the robber's feet so that he cannot run far and the police may easily overtake him. ${ }^{2}$ Similarly, the Wyingurri tribe in Australia have a magical instrument which they call a sun, because it is supposed to contain the solar heat. By placing it on a man's tracks they think they can throw him into a violent fever, which will soon burn him up. ${ }^{3}$ Practices of the same sort prevail in some parts of Europe. For example, in Germany, earth from a footprint is tied up in a cloth and hung in the chimney smoke; as it dries up, so the man withers away or his foot shrivels up. ${ }^{4}$ A Bohemian variation of the charm is to boil the earth from the footprint in a pot along with nails, needles, and broken glass : the

1 M. J. van Baarda, "Fabelen, Verhalen en Overleveringen der Galelareezen," Bijdragen tot de Taal- Land-en Volkenkunde van Nederlandsch Indië, xlv. (1895), p. 512 .

${ }^{2}$ L. Hearn, Glimpses of Unfamiliar Fapan (London, 1894), ii. 604.

${ }^{3}$ Spencer and Gillen, Native Tribes of Central Australia, p. 54 I.

4 J. Hahn, in Zeitschrift der Gesellschaft für Erdkunde zu Berlin, iv. (1869), p. $5 \circ 3$; K. Bartsch, Sagen, Märchen und Gebräuche aus Meklenburg, ii. 33०, 334, §§ 1599, $1611^{\text {abc }}$; compare p. 332, §1607; R. Andree, Ethnographische Parallelen und Vergleiche, Neue Folge, pp. 8, I1. 
man whose footprint has thus been boiled will have a lame leg for the rest of his life. ${ }^{1}$

The same superstition is turned to account by hunters for the purpose of running down the game. Thus the Thompson Indians of British Columbia used to lay charms on the tracks of wounded deer; after that they deemed it superfluous to pursue the animal any farther that day, for, being thus charmed through its footprints, it could not travel far and would soon die.." Similarly, Ojebway Indians placed "medicine" on the track of the first deer or bear they met with, supposing that this would soon bring the animal into sight, even if it were two or three days' journey off; for this charm had power to compress a journey of several days into a few hours. ${ }^{3}$

These examples may suffice to illustrate the principles of Contagious Magic.

We have now concluded our examination of the general theory of magic, but I wish for a short time to direct your attention to certain special applications of the art.

The examples of magical rites which I have put before you have been drawn almost wholly from what may be called private magic, that is, from magical rites and incantations practised for the benefit or the

' J. V. Grohmann, Aberglauben and Gebrlucbe aus Bohmen and Mahren, p. 200, 81402 .

${ }^{2}$ J. Teit, The Thompron Indians of Brisish Columbia, p. 378 (Memoirs of she Aimerican Mascum of Natural Mistory, vol. ii. Part iv. A pril s900).

2 Peter Jones, Hisery of ihe Ojetway Indiams, p. 378. 
injury of individuals. But in savage society there is commonly to be found in addition what we may call public magic, that is, sorcery practised for the benefit of the whole community. Wherever ceremonies of this sort are observed for the common good, it is obvious that the magician ceases to be merely a private practitioner and becomes to some extent a public functionary. The development of such a class of functionaries is of great importance for the political as well as the religious evolution of society. For when the welfare of the tribe is supposed to depend on the performance of these magical rites, the magician becomes a personage of much influence and repute, and may readily acquire the rank and authority of a chief or king. The profession accordingly draws into its ranks some of the ablest and most ambitious men of the tribe, because it holds out to them a prospect of honour, wealth, and power such as hardly any other career could offer. The acuter minds perceive how easy it is to dupe their weaker brother and to play on his superstition for their own advantage. Not that the sorcerer is always a knave and impostor; he is often sincerely convinced that he really possesses those wonderful powers which the credulity of his fellows ascribes to him. But the more sagacious he is, the more likely he is to see through the fallacies which impose on duller wits. Thus the ablest members of the profession must tend to be more or less conscious deceivers; and it is just these men who in virtue of their superior ability will generally come to the top 
and win for themselves positions of the highest dignity and the most commanding authority. The pitfalls which beset the path of the professional sorcerer are many, and as a rule only the man of coolest head and sharpest wit will be able to steer his way through them safely. For it must always be remembered that every single profession and claim put forward by the magician as such is false; not one of them can be maintained without deception, conscious or unconscious. Accordingly the sorcerer who sincerely believes in his own extravagant pretensions is in far greater peril and is much more likely to be cut short in his career than the deliberate impostor. The honest wizard always expects that his charms and incantations will produce their supposed effect; and when they fail, not only really, as they always do, but conspicuously and disastrously, as they often do, he is taken aback: he is not, like his knavish colleague, ready with a plausible excuse to account for the failure, and before he can find one he may be knocked on the head by his disappointed and angry employers.

The general result is that at this stage of social evolution the supreme power tends to fall into the hands of men of the keenest intelligence and the most unscrupulous character. If we could balance the harm they do by their knavery against the benefits they confer by their superior sagacity, it might well be found that the good greatly outweighed the evil. For more mischief has probably been wrought in the world by honest fools in high places than by intelligent rascals. 
Once your shrewd rogue has attained the height of his ambition, and has no longer any selfish end to further, he may, and often does, turn his talents, his experience, his resources, to the service of the public. Many men who have been least scrupulous in the acquisition of power have been most beneficent in the use of it, whether the power they aimed at and won was that of wealth, political authority, or what not. In the field of politics the wily intriguer, the ruthless victor, may end by being a wise and magnanimous ruler, blessed in his lifetime, lamented at his death, admired and applauded by posterity. Such men, to take two of the most conspicuous instances, were Julius Cæsar and Augustus. But once a fool always a fool, and the greater the power in his hands the more disastrous is likely to be the use he makes of it. The heaviest calamity in English history, the breach with America, might never have occurred if George the Third had not been an honest dullard.

Thus, so far as the public profession of magic affected the constitution of savage society, it tended to place the control of affairs in the hands of the ablest man : it shifted the balance of power from the many to the one : it substituted a monarchy for a democracy, or rather for an oligarchy of old men; for in general the savage community is ruled, not by the whole body of adult males, but by a council of elders. The change, by whatever causes produced, and whatever the character of the early rulers, was on the whole very beneficial. For the rise of monarchy appears to be an 
essential condition of the emergence of mankind from savagery. No human being is so hidebound by custom and tradition as your democratic savage; in no state of society consequently is progress so slow and difficult. The old notion that the savage is the freest of mankind is the reverse of the truth. $\mathrm{He}$ is a slave, not indeed to a visible master, but to the past, to the spirits of his dead forefathers, who haunt his steps from birth to death, and rule him with a rod of iron. What they did is the pattern of right, the unwritten law to which he yields a blind unquestioning obedience. The least possible scope is thus afforded to superior talent to change old customs for the better. The ablest man is dragged down by the weakest and dullest, who necessarily sets the standard, since he cannot rise, while the other can fall. The surface of such a society presents a uniform dead level, so far as it is humanly possible to reduce the natural inequalities, the immeasurable real differences of inborn capacity and temper, to a false superficial appearance of equality. From this low and stagnant condition of affairs, which demagogues and dreamers in later times have lauded as the ideal state, the Golden Age, of humanity, everything that helps to raise society by opening a career to talent and proportioning the degrees of authority to men's natural abilities, deserves to be welcomed by all who have the real good of their fellows at heart. Once these elevating influences have begun to operate-and they cannot be for ever suppressed-the progress of civilisation becomes comparatively rapid. The rise of one man to supreme 
power enables him to carry through changes in a single lifetime which previously many generations might not have sufficed to effect; and if, as will often happen, he is a man of intellect and energy above the common, he will readily avail himself of the opportunity. Even the whims and caprices of a tyrant may be of service in breaking the chain of custom which lies so heavy on the savage. And as soon as the tribe ceases to be swayed by the timid and divided counsels of the elders, and yields to the direction of a single strong and resolute mind, it becomes formidable to its neighbours and enters on a career of aggrandisement, which at an early stage of history is often highly favourable to social, industrial, and intellectual progress. For extending its sway, partly by force of arms, partly by the voluntary submission of weaker tribes, the community soon acquires wealth and slaves, both of which, by relieving some classes from the perpetual struggle for a bare subsistence, afford them an opportunity of devoting themselves to that disinterested pursuit of knowledge which is the noblest and most powerful instrument to ameliorate the lot of man.

Intellectual progress, which reveals itself in the growth of art and science and the spread of more liberal views, cannot be dissociated from industrial or economic progress, and that in its turn receives an immense impulse from conquest and empire. It is no mere accident that the most vehement outbursts of activity of the human mind have followed close on the 
heels of victory, and that the great conquering races of the world have commonly done most to advance and spread civilisation, thus healing in peace the wounds they inflicted in war. The Assyrians, the Greeks, the Romans, the Arabs are our witnesses in the past: we may yet live to see a similar outburst in Japan. Nor, to remount the stream of history to its sources, is it an accident that all the first great strides towards civilisation have been made under despotic and theocratic governments, like those of China, Egypt, Assyria, Mexico, and Peru, where the supreme ruler claimed and received the servile allegiance of his subjects in the double character of a king and a god. It is hardly too much to say that at this early epoch despotism is the best friend of humanity and, paradoxical as it may sound, of liberty. For after all there is more liberty in the best sense-liberty to think our own thoughts and to fashion our own destinies-under the most absolute despotism, the most grinding tyranny, than under the apparent freedom of savage life, where the individual's lot is cast from the cradle to the grave in the iron mould of hereditary custom.

So far, therefore, as the public profession of magic has been one of the roads by which the ablest men have passed to supreme power, it has contributed to emancipate mankind from the thraldom of tradition and to elevate them into a larger, freer life, with a broader outlook on the world. This is no small service rendered to humanity. And when we remember further that in another direction 
magic has paved the way for science, we are forced to admit that if the black art has done much evil, it has also been the source of much good; that if it is the child of error, it has yet been the mother of freedom and truth. 


\section{LECTURE IV}

The institution of a public order of magicians a great incentive to research-Public magicians expected to regulate the weatherMaking rain-Making sunshine-Making or calming windTendency of magicians to develop into kings in Australia, New Guinea, and Melanesia-The evolution complete in Africa-Similar evolution among the Malays-Traces of it in Europe-The divinity of kings.

IN the last lecture we ended our consideration of the general theory of magic. I pointed out that in practice the art may be employed for the benefit either of individuals or of the whole community, and that according as it is directed to one or other of these objects it may be called private or public magic. Further, we saw that the public magician occupies a position of great influence, from which, if he is a prudent and able man, he may advance step by step to the rank of a chief or king. Thus an examination of public magic conduces to an understanding of the early kingship, since in savage and barbarous society many chiefs and kings appear to owe their authority in great measure to their reputation as magicians.

Among the objects of public utility which magic may be employed to secure, the most essential is an 
adequate supply of food. We have seen that the purveyors of food, the hunter, the fisher, the farmer, all resort to magical practices in the pursuit of their various callings; but they do so as private individuals for the benefit of themselves and their families, rather than as public functionaries acting in the interest of the whole people. It is otherwise when the rites are performed, not by the hunters, the fishers, the farmers themselves, but by professional magicians on their behalf. In primitive society, where uniformity of occupation is the rule, and the distribution of the community into different classes of workers has hardly begun, every man is more or less his own magician; he practises charms and incantations for his own good and the injury of his enemies. But a great step in advance has been taken when a special class of magicians has been instituted; when, in other words, a number of men have been set apart for the express purpose of benefiting the whole community by their skill, whether that skill be directed to the healing of disease, the forecasting of the future, the regulation of the weather, or any other object of general utility. The impotence of the means adopted by most of these practitioners to accomplish their ends ought not to blind us to the immense importance of the institution itself. Here is a body of men relieved, at least in the higher stages of savagery, from the need of earning their livelihood by hard manual toil, and allowed, nay expected and encouraged, to prosecute researches into the secret ways of nature. It was at once their duty and their interest to know more than their fellows, to 
acquaint themselves with everything that could aid man in his arduous struggle with nature, everything that could mitigate his sufferings and prolong his life. The properties of drugs and minerals, the causes of rain and drought, of thunder and lightning, the changes of the seasons, the phases of the moon, the daily and yearly journeys of the sun, the motions of the stars, the mystery of life, and the mystery of death, all these things must have excited the wonder of these early philosophers, and stimulated them to find solutions of problems that were doubtless often thrust on their attention in the most practical form by the importunate demands of their clients, who expected them not merely to understand but to regulate the great processes of nature for the good of man. That their first shots at truth fell very far wide of the mark could hardly be helped. The slow, the never-ending approach to truth, as I have pointed out, consists in perpetually forming and testing hypotheses, accepting those which at the time seem best to fit the facts, and rejecting the others. The views of natural causation embraced by the savage magician no doubt appear to us manifestly false and absurd; yet in their day they were legitimate hypotheses, though they have not stood the test of experience. Ridicule and blame are the just meed, not of those who devised these crude theories, but of those who obstinately adhered to them after better had been propounded. Certainly no men ever had stronger incentives in the pursuit of truth than these savage sorcerers. To maintain at least an appearance of knowledge was absolutely 
necessary; a single mistake detected might cost them their life. This no doubt led them to practise imposture for the purpose of concealing their ignorance ; but it also supplied them with the most powerful motive for substituting a real for a sham knowledge, since, if you would appear to know anything, by far the best way is actually to know it. Thus, however justly we may reject the extravagant pretensions of magicians and condemn the deceptions which they have practised on mankind, the original institution of this class of men has, take it all in all, been productive of incalculable good to humanity. They were the direct predecessors, not merely of our physicians and surgeons, but of our investigators and discoverers in every branch of natural science. They began the work which has since been carried to such glorious and beneficent issues by their successors in after ages; and if the beginning was poor and feeble, this is to be imputed to the inevitable difficulties which beset the pursuit of knowledge rather than to the natural incapacity or wilful fraud of the men themselves.

Of the things which the public magician sets himself to do for the good of his tribe, one of the chief is to control the weather and especially to ensure an adequate fall of rain. Water is the first essential of life, and in most countries the supply of it depends upon showers. Without rain vegetation withers, animals and men languish and die. Hence in savage communities the rain-maker is a very important personage; and often a special class of magicians is formed for the purpose of 
regulating the heavenly water-supply. The methods by which they attempt to discharge the duties of their office are commonly, though not always, based on the principle of homœopathic or imitative magic. If they wish to make rain they imitate it by sprinkling water or by mimicking clouds : if their object is to stop rain and to cause drought, they avoid water and resort to warmth and fire for the sake of drying up the too abundant moisture. Examples will illustrate their various modes of procedure.

Thus in. time of drought the Tarahumares of Mexico will sometimes throw water towards the sky in order that God may replenish his supply. And in the month of May they always burn the grass, so that the whole country is then wrapped in smoke, and travelling becomes difficult. They think that this is necessary to produce rain, clouds of smoke being, in their opinion, equivalent to rain-clouds. ${ }^{1}$ In the Mara tribe of Northern Australia the rain-maker goes to a pool and sings over it his magic song. Then he takes some of the water in his hands, drinks it, and spits it out in various directions. After that he throws water all over himself, scatters it about, and returns to the camp. Rain is supposed to follow. ${ }^{2}$ To make rain a party of Ainos will scatter water by means of sieves, while others will take a porringer, fit it up with sails and oars as if it were a boat, and then push or draw it about the village and gardens, probably to

1 C. Lumholtz, Unkrowen Ríexico (London, 1903), i. $180,330$.

2 Spencer and Gillen, Nerihern Tribes of Ceritral Australid, pp. 31349. 
signify that the country will soon be flooded with water. ${ }^{1}$ In Laos, a province of Siam, the festival of the New Year takes place about the middle of April. The people assemble in the pagodas, which are decorated with flowers and illuminated. The Buddhist monks perform the ceremonies, and when they come to the prayers for the fertility of the earth, the worshippers pour water into little holes in the floor of the pagoda as a symbol of the rain which they hope Buddha will send down on the rice-fields. ${ }^{2}$ The custom is clearly one of those combinations of magic with religion which meet us so often in the ritual of comparatively advanced peoples. The Arab historian Makrisi describes a method of stopping rain which is said to have been resorted to by a tribe of nomads in Hadramaut. They cut a bough from a certain tree in the desert, set it on fire, and then sprinkled the burning branch with water. After that the vehemence of the rain abated, just as the water vanished when it fell on the glowing bough. ${ }^{3}$ Some of the eastern Angamis of Manipur are said to perform a somewhat similar ceremony for the opposite purpose, in order, namely, to produce rain. The head of the village puts a burning brand on the grave of a man who has died of burns, and then quenches the brand with water, while he prays that rain may fall. Here the putting out the fire with water, which is an imitation of rain, is reinforced by the

1 J. Batchelor, The Ainu and their Folk-lore (London, 1901), p. 333.

2 Tournier, Notice sur le Laos Franģais (Hanoi, 1900), p. 80.

3 P. B. Noskowijj, Mąrizii de valle Hadhramaut litellus arabice editus et illustratus (Bonn, 1866), pp. 25 sq. 
influence of the dead man, who, having been burnt to death, will naturally be anxious for the descent of rain to cool his scorched body and relieve his pangs. ${ }^{1}$

Other people besides the Arabs have used fire as a means of stopping rain. Thus the Telugus of India send a little girl out into the rain with a burning piece of wood in her hand, which she has to show to the falling drops. This is supposed to arrest the downpour. ${ }^{2}$ At Port Stevens in New South Wales the medicinemen used to drive away rain by throwing fire-sticks into the air, while at the same time they puffed and shouted. ${ }^{3}$ Again, any man of the Anula tribe in Northern Australia can stop rain by simply warming a green stick in the fire, and then striking it against the wind. ${ }^{4}$

Among the Toradjas of Central Celebes the raindoctor, whose special business it is to drive away rain, takes care not to touch water either before or after the performance of his professional duties, still less while he is actually engaged in the discharge of them. He does not bathe, he eats with unwashed hands, he drinks nothing but palm wine, and if he has to cross a stream he avoids stepping in the water. Having thus prepared himself for his task, he has a small hut built outside of the village in a rice-field, and in this hut he keeps up a

1 T. C. Hodson, "The Native Tribes of Manipur," Gournal of the Anthropological Instirute, $\times \times \times \mathrm{i} .(1901)$, p. 308 .

2 Indian Antigurry, xxiv. (1895), p. 359.

3 A. W. Howitt, Native Tribes of South-Fast Australia, p. 398.

- Spencer and Gillen, Northern Tribes of Central Aussralia, p. 315. 
little fire, which on no account may be suffered to go out. In the fire he burns various kinds of wood, which are supposed to possess the property of driving off rain ; and he puffs in the direction from which the rain threatens to come, holding in his hand a packet of leaves and bark which derive a similar cloud-compelling virtue, not from their physiological properties, but from their names, which happen to signify something dry or volatile. If clouds should appear in the sky while he is at work, he takes lime in the hollow of his hand and blows it towards them. Lime, being so very dry, is obviously well adapted to disperse the damp clouds. Should rain afterwards be wanted, he has only to pour water on his fire, and immediately the rain will descend in sheets. ${ }^{1}$ Again, in Central Celebes, when there has been a long drought and the rice-stalks begin to shrivel up, many of the villagers, especially the young folk, go to a neighbouring brook and splash each other with water, shouting noisily, or squirt water on one another through bamboo tubes. Sometimes they imitate the plump of rain by smacking the surface of the water with their hands, or by placing an inverted gourd on it and drumming on the gourd with their fingers. ${ }^{2}$ The Karo-bataks of Sumatra have a rain-making ceremony which lasts a week. The men go about with bamboo squirts and the women with bowels of water, and they drench each other or throw the water into the air, and

1 A. C. Kruijt, “ Regen lokken en regen verdrijven bij de Toradja's van MiddenCelebes," Tijdschrift voor Indische Taal- Land-en Volkenkunde, xliv. (1901), pp. 8-10.

${ }^{2}$ A. C. Kruijt, op. cit. pp. 1 sq. 
when it drips down on them they cry, "The rain has come." 1

Sometimes, as we have seen, the rain-charm operates partly or wholly through the dead. An Armenian way of making rain is to dig up a skull and fling it into running water. ${ }^{2}$ In Halmahera there is a practice of throwing stones on a grave, in order that the ghost may fall into a passion and avenge the disturbance, as he imagines, by sending heavy rain. ${ }^{3}$ Sometimes, in order to procure rain, the Toradjas of Central Celebes make an appeal to the compassion of the dead. Thus in one of their villages there is the grave of a famous chief, the grandfather of the present ruler. When the land suffers from unseasonable drought, the people go to this grave, pour water on it, and say, "O grandfather, have pity on us; if it is your will that this year we should eat, then give rain." After that they hang a bamboo tube full of water over the grave; there is a small hole in the lower end of the bamboo, so that the water drips from it continually. The tube is always refilled with water until rain drenches the ground. In this ceremony you will observe that religion is blent with magic, for the prayer to the dead chief, which is purely religious, is eked out with a magical imitation of rain at his grave. In order to procure rain the Wagogo of German East Africa sacrifice black fowls, black sheep, and black cattle at the graves of their ancestors, and the

\footnotetext{
'M. Joustra, "De Zending onder de Karo-Batak's, Mededecingen var surge hes Siederlandsche Zendelinge enoorschapp, xli. (1897), p. 158.

2 M. Abeghian, Dor armenizche Volksglaube (Leipaic, 1899), p. 93.

A. C. Kruijt, op. sir. p.6. A. C. Kruijt, op. sir. pp. 340
} 
rain-maker wears black clothes during the rainy season. ${ }^{1}$ Here again the religious appeal to the spirits of the dead is strengthened by the black colour of the victims and of the clothes, which is an imitation of dark rainclouds.

Sometimes the rain-maker resorts to an entirely different mode of obtaining the needed showers. He neither imitates the fall of rain nor prays to his forefathers, but attempts to extort the waters of heaven from those supernatural beings who have, so to say, cut him off at the main. The Chinese are adepts in the art of thus taking the kingdom of heaven by storm. If the god does not give rain, they will threaten and beat him; sometimes they publicly depose him from the rank of deity. On the other hand, if the wished-for showers fall, the god may get a step of promotion by imperial decree. ${ }^{2}$ It is said that in the reign of Kia-King, fifth emperor of the Manchu dynasty, a long drought desolated several provinces of Northern China. Processions were of no avail; the rain-dragon hardened his heart and would not let a drop fall. At last the emperor lost patience and condemned the recalcitrant deity to perpetual exile on the banks of the river Illi. The decree was in process of execution: the divine criminal, with a touching resignation, was already traversing the deserts

1 H. Cole, "Notes on the Wagogo of German East Africa," Fournal of the Anthropological Institute, xxxii. (1902), p. 325.

2 Mgr. Rizzolati, in Annales de la Propagation de la Foi, xvi. (1844), p. $35^{\circ}$; Mgr. Retord, $i b$. xxviii. (1856), p. 102. In Tonquin also a mandarin has been known to whip an image of Buddha for not sending rain. See Annales de l'Association de la Propagation de la Foi, iv. (1830), p. 330. 
of Tartary to work out his sentence on the borders of Turkestan, when the judges of the high court of Peking, moved with compassion, flung themselves at the feet of the emperor and implored his pardon for the poor devil. The emperor consented to revoke his doom, and a messenger set off at full gallop to bear the tidings of mercy to the executors of the imperial justice. The dragon was reinstated in his office on condition of performing his duties a little better in future. $^{1}$. In April 1888 the mandarins of Canton prayed to the god Lung-wong to stop the incessant downpour of rain; and when he turned a deaf ear to their petitions they put him in a lock-up for five days. This had a salutary effect. The rain ceased and the god was restored to liberty. Some years before, in time of drought, the same deity had been chained and exposed to the sun for days in the courtyard of his temple in order that he might feel for himself the urgent need of rain. ${ }^{2}$ So when the Siamese are in want of rain, they set out their idols in the blazing sun; but if they need dry weather, they unroof the temples and let the rain pour down on the idols. They think that the inconvenience to which the gods are thus subjected by the inclemency of the weather will induce them to grant the wishes of their worshippers. ${ }^{3}$

You may smile perhaps at the meteorology of the

'Huc, L'empire shinois, i. 248 sq.

"Rev. E. Z. Simmons, "Idols and Spirits," Chinese Recorder and Missionary Journal, xix. (1888), p. 502.

3 Mgr. Bruguiere, in Anrales de l'Aisociastion de la Progagasion de la Foi, v. (1831), p. 138. 
Far East; but precisely similar modes of procuring rain have been resorted to in Europe within our own lifetime. By the end of April I 893 there was great distress in Sicily for lack of water. The drought had lasted six months. Every day the sun rose and set in a sky of cloudless blue. The gardens of the Conca d' Oro, which surround Palermo with a magnificent belt of verdure, were withering. Food was becoming scarce. The people were in great alarm. All the most approved methods of procuring rain had been tried without effect. Processions had traversed the streets and the fields. Men, women, and children, telling their beads, had lain whole nights before the holy images. Consecrated candles had burned day and night in the churches. Palm branches, blessed on Palm Sunday, had been hung on the trees. At Solaparuta, in accordance with a very old custom, the dust swept from the churches on Palm Sunday had been spread on the fields. In ordinary years these holy sweepings preserve the crops; but that year, if you will believe me, they had no effect whatever. At Nicosia the inhabitants, bare-headed and bare-foot, carried the crucifixes through all the wards of the town and scourged each other with iron whips. It was all in vain. The great St. Francis of Paola himself, who annually performs the miracle of rain and is carried every spring through the market-gardens, either could not or would not help. Masses, vespers, concerts, illuminations, fire-works, - nothing could move him. At last the peasants began to lose 
patience. Most of the saints were banished. At Palermo they dumped St. Joseph in a garden to see the state of things for himself, and they swore to leave him there in the sun till rain fell. Other saints were turned, like naughty children, with their faces to the wall. Others again, stripped of their beautiful robes, were exiled far from their parishes, threatened, grossly insulted, ducked in horseponds. At Caltanisetta the golden wings of St. Michael the Archangel were torn from his shoulders and replaced with wings of pasteboard: his purple mantle was taken away and a clout wrapt about him instead. At Licata the patron saint, St. Angelo, fared even worse, for he was left without any garments at all: he was reviled, he was put in irons, he was threatened with drowning or hanging. "Rain or the rope !" roared the angry people at him, as they shook their fists in his face. ${ }^{1}$

As the magician thinks he can make rain, so he fancies he can cause the sun to shine and can hasten or stay its going down. Thus the natives of New Caledonia imagine that they can cause a drought by means of a disc-shaped stone with a hole in it. At the moment when the sun rises, the wizard holds this stone in his hand and passes a burning brand repeatedly into the hole, while he says, "I kindle the sun, in

1 G. Vuillier, "La Sicile, impressions du présent et du passé," Tour du Monde, Lxvii. (1894). pp. 54 9. As to St. Francis of Prola, who died in 1507 and wat canonised by Leo $\mathbf{X}$. in 1589, see P. Ribadeneira, Fles Sancrorum, ciol Pite do Samsi (Venice, 1763), i. 252 4.; Th. Trede, Das Heidentum in der romischen Kirshe, iii. 45-47. He was sent for by Louis XI. of France, and his fame as a worker of miracles is still spread all over the south of Italy. 
order that he may eat up the clouds and dry up our land, so that it may produce nothing." 1 When the mists lay thick on the Sierras of Peru, the Indian women used to rattle the silver and copper ornaments which they wore on their breasts, and they blew against the fog, hoping thus to disperse it and make the sun shine through. Another way of producing the same result was to burn salt or scatter ashes in the air. ${ }^{2}$ The Guarayo Indians also threw ashes in the air for the sake of clearing up the clouded evening sky. Perhaps the fall of the ashes to the ground was supposed to make the clouds disappear from the sky. ${ }^{3}$ The offering made by the Brahman in the morning is supposed to produce the sun, for we are told that "assuredly it would not rise, were he not to make that offering." 4 The ancient Mexicans conceived the sun as the source of all vital force; hence they named him "He by whom men live." But if he bestowed life on the world, he needed also to receive life from it. And as the heart is the seat and symbol of life, bleeding hearts of men and animals were presented to the sun to maintain him in vigour and enable him to run his course across the sky. Hence the Mexican sacrifices to the sun were magical rather than religious, being designed, not so much to please and propitiate him, as

1 Father Lambert, in Missions Catholiques, xxv. (1893), p. 116; id., Moeurs et Superstitions des Néo-Caledoniens (Nouméa, 1900), pp. 296 sq. The magic formula differs slightly in the two passages : in the text $I$ have followed the second.

2 P. J. Arriaga, Extirpacion de la Idolatria del Piru (Lima, 162 1), p. 37.

3 A. d'Orbigny, Voyage dans l'Amérique Meridionale, iii. (Paris and Strasburg, 1844), p. 24.

${ }_{4}^{4}$ Satapatha-Brâhmana, translated by J. Eggeling, Part i. p. 328 . 
physically to renew his energies of heat, light, and motion. The constant demand for human victims to feed the solar fires was met by waging war every year on the neighbouring tribes and bringing back bands of captives to be sacrificed on the altar. Thus the ceaseless wars of the Mexicans and their cruel system of human sacrifices, the most monstrous on record, sprang in great measure from a mistaken theory of the solar system. No more striking illustration could be given of the disastrous consequences that may flow in practice from a purely speculative error. ${ }^{1}$ The ancient Greeks believed that the sun drove in a chariot across the sky; hence the Rhodians, who worshipped the sun as their chief deity, annually dedicated a chariot and four horses to him, and flung them into the sea for his use. ${ }^{2}$ Doubtless they thought that after a year's work his old horses and chariots would be worn out. From a like motive, probably, the idolatrous kings of Judah dedicated chariots and horses to the sun, ${ }^{3}$ and the Spartans, ${ }^{4}$ Persians, ${ }^{5}$ and

1 E. J. Payne, History of the Nezu World called America, i. (Oxford, 1892), pp. 520-523; K. Th. Preuss, in Verhandlungen der Berliner anshropologischen Gesellschaff, November 15, 1902, pp. (449) sq., (457) sq.; id. "Die Feuergötter als Ausgangspunkt zum Verständniss der mexikanischen Religion," Mirsheilungen der anthropolog. Gesellschaft in Wien, xxxiii. (1903), pp. 157 sq., 163. A Mexican legend relates how in the beginning the gods sacrificed themselves by fire in order to set the sun in motion. See B. de Sahagun, Hissoire génerale des choses de las Nowoclle Espagne (Paris, 1880), bk. vii. ch. 2, pp. 478 sqg.

2 Festus, s.v. "October equus," p. $\$ 81$, ed. C. O. Mniler.

$3_{2}$ Kings xxiii. 11. Compare H. Zimmern, in E. Schrader's Die Keilinschrifien wad das Alse Tessament ${ }^{3}$ (Berlin, 1902), pp. 369 sq.

- Pausanias, iii. 20. 4.

- Xenophon, Cyropaed. viii. 3. 24 ; Philostratur, Vir. Apollon. i. 31. 2 ; Ovid, Fasti, i. $3^{8} 5$ sq.; Pausanias, iii. 20. 4. Compare Xenophon, Anabasis, iv. 5.35 ; Trogus Pompeius, i. 80. 5 . 
Massagetæ $^{1}$ sacrificed horses to him. The Spartans performed the sacrifice on the top of the lofty range of Mt. Taygetus, behind which they saw the great luminary set every night. It was as natural for the inhabitants of the valley of Sparta to do this as it was for the islanders of Rhodes to throw the chariot and horses into the sea, into which the sun seemed to them to sink at evening. For thus, whether on the mountains or in the sea, the fresh horses stood ready for the weary god where they would be most welcome, at the end of his day's journey.

As some people think they can light up the sun, so others fancy they can retard or stop him. When the sun is going southward in autumn and sinking lower and lower in the Arctic sky, some of the Esquimaux play the game of cat's cradle in order to catch him in the meshes of the string and so prevent his disappearance below the horizon. On the contrary, in spring, when the sun is moving northward and mounting higher and higher in the heaven, they play the game of cup-and-ball to hasten his return and enable him to bound nimbly upwards, like the ball in the air. ${ }^{2}$ The whole record of savage superstition could hardly furnish a more glaring instance of the futility of magic than this attempt of the Esquimaux to regulate the sun's course in the sky by playing at cat's cradle and

1 Herodotus, i. 216 ; Strabo, xi. 8. 6. Many Asiatics held that the sun rode a horse, not a chariot. See Dittenberger, Sylloge Inscriptionum Graecarum, ${ }^{2}$ No. 754, with note 4 .

${ }^{2}$ Fr. Boas, "The Eskimo of Baffin Land and Hudson Bay," Bulletin of the American Museum of Natural History, xv. (1901), p. 15r. 
cup-and-ball. As some people imagine they can hasten the sun, so others fancy they can jog the tardy moon. The natives of German New Guinea, like many other savages, reckon months by the moon, and some of them have been known to throw stones and spears at the moon in order to accelerate its progress and so to hasten the return of their friends, who were away from home for twelve months, working on a tobacco plantation. ${ }^{1}$

Lastly, the wizard believes that by his ceremonies and incantations he can direct the course of the stormy wind and can make it blow or be still at his pleasure. Thus if a Cherokee wizard desires to turn aside an approaching storm, he faces it and recites a spell with outstretched hand. Then he gently blows in the direction in which he wishes it to go, waving his hand towards that quarter as if he were pushing away the storm. ${ }^{2}$ The natives of Bibili, an island off German New Guinea, are reputed to raise tempests by blowing with their mouths. In stormy weather some of their neighbours will say, "The Bibili folk are at it again, blowing away." 3 The natives of Murray Island in Torres Straits used to make a great wind blow from the south-east by pointing cocoa-nut leaves and other plants at two granitic boulders on the shore. So long as the leaves remained

1 K. Vetter, Komm herbber und hilf uns! oder die Arbeit der Newen Destelsauer Mission in Deuesch Neu-Guinea, ii. (Barmen, 1898), p. 29 ; id. in B. Hagen's Uneer den Papua's (Wiesbaden, 1899), p. 287.

"J. Mooney, "Sacred Formulas of the Cherokees," Srueneh Annual Report of the Bureas of Ethnology (Washington, 1891), pp. 387 s.

B. Hagen, Unter den Papua's, p. 269. 
there, the wind sat in that quarter. But with great discretion they only performed the ceremony during the prevalence of the south-east monsoon. They knew better than to try to raise a south-east wind while the north-west monsoon was blowing. ${ }^{1}$ On the top of a mountain in Togo, a district of German West Africa, there resides a fetish called Bagba, who is supposed to control the wind and the rain. His priest is said, like Æolus, to keep the winds shut up in great pots. ${ }^{2}$ An ancient Greek charm to prevent storms from damaging the crops was to bury a toad in a new earthen pot in the middle of the field. ${ }^{3}$ Even in Christian times, under the reign of Constantine, a certain Sopater suffered death at Constantinople on a charge of binding the winds by magic, because it happened that the corn-ships of Egypt and Syria were detained afar off by calms or head-winds, to the rage and disappointment of the hungry Byzantine rabble. ${ }^{4}$

The sketch which I have thus given you of the theory and practice of magic may suffice for our purpose. We now revert to our special subject, the sacred character and magical functions of kings in early society. I have pointed out that among savages the public magician is a personage of such influence that under favourable circumstances he may easily attain to the rank of a chief or king. I shall now put before you

1 A. C. Haddon, Head-hunters (London, 1901), p. 60.

2 Lieut. Herold, in Mittheilungen aus den Deutschen Schutzgebieten, v. (1892), pp. 144 sq.; H. Klose, Togo unter deutscher Flagge (Berlin, I899), p. 189.

3 Pliny, Nat. Hist. xviii. 294. Compare Geoponica, ii. 18.

4 Eunapius, Vitae Sophistarum: Aedesius, p. 463 (Didot edition). 
some particular cases where this evolution appears either to be in process of taking place or actually to have been accomplished.

Let us begin by looking at the lowest race of men as to whom we possess comparatively full and accurate information, I mean the aborigines of Australia. These savages are ruled neither by chiefs nor kings. So far as their tribes can be said to have a political constitution, it is a democracy or rather an oligarchy of old and influential men, who meet in council and decide on all measures of importance, to the practical exclusion of the younger men. Their deliberative assembly answers to the senate of later times: if we had to coin a word for such a government of elders we might call it a gerontocracy. ${ }^{1}$ The elders who in Australia thus meet and direct the affairs of their tribe appear to be for the most part the headmen of their respective totem groups. As you probably know, the Australian aborigines are divided into a great many clans or stocks, each of which stands in a very intimate relation to a particular species of natural objects, generally of animals or plants, which is called its totem. Now in Central Australia, where the barren nature of the country and the almost complete isolation from foreign influences have retarded progress and preserved the natives on the whole in their most primitive state, the headmen of the various totem stocks or clans are charged with the important task of performing magical ceremonies for the

1 The government of the natives of the western islands of Torres Straits is similar. See A. C. Haddon, in Reports of the Cambridge Anshropological Expredision to Torres Straits, v. 263 sq. 
multiplication of the totems, and as the great majority of the totems are edible animals or plants, it follows that these men are commonly expected to provide the people with food by means of magic. Others have to make the rain to fall or to render other services to the community. In short, among the tribes of Central Australia the headmen are public magicians. Further, their most important function is to take charge of the sacred storehouse, usually a cleft in the rocks or a hole in the ground, where the holy stones and sticks are kept, with which the souls of all the people, both living and dead, appear to be in a manner bound up. Thus, while the headmen have certainly to perform what we should call civil duties, such as to inflict punishment for breaches of tribal custom, their principal functions are sacred or magical. ${ }^{1}$

Again, in the tribes of South-Eastern Australia the headman was often, sometimes invariably, a magician. Thus in the southern Wiradjuri tribe the headman was always a wizard or medicine-man. There was one for each local division. He called the people together for the initiation ceremonies or to discuss matters of public importance. ${ }^{2}$ In the Yerkla-mining tribe the medicinemen are the headmen; they are called Mobung-bai, from mobung, " magic." They decide disputes, arrange marriages, conduct the ceremonies of initiation, and in certain circumstances settle the formalities to be observed

1 Spencer and Gillen, Native Tribes of Central Australia, pp. 9-1 5, 154, $159-205$; id., Northern Tribes of Central Australia, pp. 20-27, 285-297, 309 sq., 316 ; A. W. Howitt, Native Tribes of South-East Australia, pp. 320-326.

2 A. W. Howitt, op. cit. p. $3 \circ 3$. 
in ordeals of battle. "In fact, they wield authority in the tribe, and give orders where others only make requests." 1 Again, in the Yuin tribe there was a headman for each local division, and in order to be fitted for his office he had, among other qualifications, to be a medicine-man; above all, he must be able to perform magical feats at the initiation ceremonies. The greatest headman of all was he who on these occasions could bring up the largest number of things out of his inside. ${ }^{2}$ In fact the budding statesman and king must be above all things a conjurer in the most literal sense of the word. Some forty years ago the principal headman of the Dieri tribe was a certain Jalina piramurana, who was known among the colonists as the Frenchman on account of his polished manners. He was not only a brave and skilful warrior, but also a powerful medicine-man, greatly dreaded by the neighbouring tribes, who sent him presents even from a distance of a hundred miles. $\mathrm{He}$ boasted of being the "tree of life," for he was the head of a totem consisting of a particular sort of seed which forms at certain times the chief vegetable food of these tribes. His people spoke of him as the plant itself (manyura) which yields the edible seed. ${ }^{3}$ On the whole, it is highly significant that in the most primitive society now open to our observation it is especially the magicians or medicine-men who appear to be in the act of developing into chiefs.

A. W. Howitt, op. cir. p. 313.

2 A.W. Howitt, op. cis. p. 314.

A. W. Howitt, op. cis. pp. 297-299. For more examples of headmen who are also magicians, sec ib. pp. 301 4.., 302, 317. 
When we pass from Australia to New Guinea we find that, though the natives occupy a far higher level of culture than the Australian aborigines, the constitution of society among them is still essentially democratic or oligarchic, and chieftainship exists only in embryo. But here also it would seem that the medicine-men are on the road to become chiefs. Thus Sir William MacGregor tells us that in British New Guinea no one has ever arisen wise enough, bold enough, and strong enough to become the despot even of a single district. "The nearest approach to this," says Sir William MacGregor, "has been the very distant one of some person becoming a renowned wizard ; but that has only resulted in levying a certain amount of blackmail." 1 We are told that in the Toaripi or Motumotu tribe of British New Guinea chiefs have not necessarily supernatural powers, but that a sorcerer is looked upon as a chief. Some years ago, for example, one man of the tribe was a chief because he was supposed to rule the sea, calming it or rousing it to fury at his pleasure. Another owed his power to his skill in making the rain to fall, the sun to shine, and the plantations to bear fruit. ${ }^{2}$ It is believed that the chief of Mowat, in British New Guinea, can affect the growth of crops for good or ill, and coax the turtle and dugong to come from all parts of the sea and allow themselves to be caught. ${ }^{3}$

1 Sir W. MacGregor, British Nerw Guinea (London, 1897), p. 41.

$2 \mathrm{~J}$. Chalmers, "Toaripi," Fournal of the Anthropological Institute, xxvii. (x898), p. 334 .

3 E. Beardmore, "The Natives of Mowat Daudai, New Guinea," Fournal of the Anthropological Institute, xix. (1890), p. 464 . 
Again, we hear of a chief of Kolem, in German New Guinea, who enjoyed a great reputation as a sorcerer ; it was believed that he could make wind and storm, rain and sunshine, and visit his enemies with sickness and death. ${ }^{1}$

Turning now to the Melanesian islands, we are told by Dr. Codrington that among these savages "as a matter of fact the power of chiefs has hitherto rested upon the belief in their supernatural power derived from the spirits or ghosts with which they had intercourse. As this belief has failed, in the Banks' Islands, for example, some time ago, the position of a chief has tended to become obscure; and as this belief is now being generally undermined, a new kind of chief must needs arise, unless a time of anarchy is to begin." 2 According to a native Melanesian account, the authority of chiefs rests entirely on the belief that they hold communication with mighty ghosts, and possess that supernatural power whereby they are able to bring the influence of the ghosts to bear. If a chief imposed a fine, it was paid because the people universally dreaded his ghostly power, and firmly believed that he could inflict calamity and sickness upon such as resisted him. As soon as any considerable number of his subjects began to disbelieve in his influence with the ghosts, his power to levy fines was shaken. ${ }^{3}$ In the northern New Hebrides the son does not inherit the chieftainship, but he inherits, if his father can manage

1 M. Krieger, New-Guines (Berlin, N.D.), P. 334.

2 R. H. Codrington, The Melancsians (Oxford, 1891), p. 46.

R. H. Codrington, op. cif. p. 52 . 
it, what gives him chieftainship, namely, his father's supernatural power, his charms, magical songs, stones and apparatus, and his knowledge of the way to approach spiritual beings. ${ }^{1}$

Still rising in the scale of civilisation, or rather of savagery, we come to Africa, where both the chieftainship and the kingship are fully developed; and here the evidence for the evolution of the chief out of the magician, and especially out of the rain-maker, is comparatively plentiful. Thus among the Wagogo of German East Africa the main power of the chiefs, we are told, is derived from their art of rain-making. If a chief cannot make rain himself, he must procure it from some one who can. ${ }^{2}$ The medicine-men of the Masai, according to Sir Harry Johnston, are not uncommonly their chiefs, and the supreme chief is almost invariably a powerful medicine-man. These men are priests as well as doctors, skilled in interpreting omens and dreams, in averting ill-luck, and in making rain. ${ }^{3} \quad$ The head chief is expected not only to make rain, but to destroy the enemies of the Masai in war by means of his magic. ${ }^{4}$ With regard to this supreme chief of the Masai I will translate to you the account of his office and functions which Captain Merker gives in his book on the Masai published last year. The writer is a German officer serving in East Africa.

1 R. H. Codrington, op. cit. p. 56.

2 H. Cole, "Notes on the Wagogo of German East Africa," Fournal of the Anthropological Institute, xxxii. (1902), p. 321 .

3 Sir Harry Johnston, The Uganda Protectorate (London, 1902), ii. 830.

${ }^{4}$ Baron C. C. von der Decken, Reisen in Ost-Afrika, ii. (Leipsic and Heidelberg, 1871 , p. 24. 
He says: "The most prominent clan of the whole Masai people is the En gidon, because to it belong not only the family of the chief (ol oiboni), but also the family of the magicians. The designation chief is, strictly speaking, not quite correct, since the chief (ol oiboni) does not govern directly and exercises no real administrative function. He rules only indirectly; the firm belief of his subjects in his prophetic gifts and in his supernatural power of sorcery gives him an influence on the destinies of the people. Despotism and cruelty, as such we find among all negro rulers, are alien to him. He is not so much a ruler as a national saint or patriarch. The people speak of his sacred person with shy awe, and no man dares to appear before this mighty personage without being summoned. The aim of his policy is to unite and strengthen the Masai. While he allows free play to the predatory instincts of the warriors in raids on other tribes, he guards his own people from the scourge of civil war, to which the ceaseless quarrels of the various districts with each other would otherwise continually give occasion. This influence of his is rendered possible by the belief that victory can only be achieved through the secret power of the war-medicine which none but he can compound, and that defeat would infallibly follow if he were to predict it. Neither he nor his nearest relatives march with the army to war. He supplies remedies, generally in the shape of magical medicines, for plagues and sicknesses, and he appoints festivals of prayer in honour of the Masai god ' $\mathrm{Ng}$ ai. $\mathrm{He}$ delivers his predictions by means of an oracular 
game like the telling of beads." 1 And just as Samson's miraculous strength went from him when his hair was shorn, so it is believed that the head chief of the Masai would lose his supernatural powers if his chin were shaved. Captain Merker tells us further that so firmly did the Masai believe in the magical gift of healing possessed by the late chief Mbatyan, that people are said to have been often cured of their infirmities by faith alone. ${ }^{2}$ The same chief, according to Captain Merker, actually discovered a mode of inoculation which protected the cattle against the ravages of lung disease. If this statement is correct, we have here a striking instance of a most beneficent scientific discovery made by a savage magician, which illustrates what I have said as to the immense advantages which at a certain stage of social development may flow from the institution of a public body of magicians or medicine-men.

The Suk and Turkana peoples of East Africa, who are akin to the Masai, distinguish between their chiefs and their medicine-men, who wield great power; but very often the medicine-man is a chief by virtue of his skill in medicine or occult arts. ${ }^{3}$ Among the negroes of the Upper Nile the medicine-men are generally the chiefs." Thus among the Bongo (to quote from Schweinfurth) "good spirits are quite unrecognised, and, according to the general negro idea, no benefit can

1 M. Merker, Die Masai (Berlin, 1904), pp. 18 sq. I have slightly abridged the writer's account.

2 M. Merker,op. cit. pp. 20 sq. As to the medicine-men of the Masai, see further A. C. Hollis, The Masai, their Language and Folk-lore (Oxford, 1905), pp. 324-330.

${ }^{3}$ Sir H. Johnston, The Uganda Protectorate, ii. 85 x.

4 Sir H. Johnston, op. cit. ii. 779. 
ever come from a spirit at all. They affirm that the only thing they know about spirits is that they do mischief, and certain it is that they have no conception either of there being a Creator or any kind and ruling power above. They assert that there is no resource for obtaining communication with spirits except by means of certain roots, which may be of service likewise in employing the powers of evil to inflict injury on others. To their knowledge of this magic may be attributed much of the influence which the native chiefs, independently of their authorised rule, exercise over the mass of the people in their districts. This may be witnessed among the Bary on the Bahr-el-Gebel, and a hundred other tribes, who yield the greatest deference to the controllers or captains of their communities." 1 In the Dinka or Denka nation, to the north-east of the Bongo, men who are supposed to be in close communication with spirits pass for omnipotent; it is believed that they make rain, conjure away all calamities, foresee the future, exorcise evil spirits, know all that goes on even at a distance, have the wild beasts in their service, and can call down every kind of disaster on their enemies. One of these men became the richest and most esteemed chief of the Kic tribe through his skill in ventriloquism. He kept a cage from which the roars of imaginary lions and the howls of imaginary hyenas were heard to proceed; and he gave out that these beasts guarded his house, and were ready at his bidding to rush forth on his enemies. The dread which he

1 G. Schweinfurth, The Heart of Africe (London, 1878), i. 14497. 
infused among the tribe, and beyond it, was incredible : from all sides oxen were sent him as presents, so that his herds were the most numerous of the neighbourhood. Another of these conjurers in the Tuic tribe had a real tame lion and four real fat snakes, which slept in front of his door, to the great awe of the negroes, who could only attribute their pacific demeanour to sorcery. ${ }^{1}$ But it does not appear that the real lion inspired nearly so much terror as the imaginary one ; from which we may infer that among these people ventriloquism is a more solid basis of political power even than lion-taming. The Lendu tribe, to the west of Lake Albert, in Central Africa, firmly believe that certain people possess the power of making rain. Among them the rain-maker either is a chief or almost invariably becomes one. ${ }^{2}$

Again, the Wanyoro of Central Africa have a great respect for the dispensers of rain, whom they load with a profusion of gifts. The great dispenser, who has absolute and uncontrollable power over the rain, is the king; but he can divide his power with other persons, so that the benefit may be distributed over various parts of the kingdom. ${ }^{3}$ With regard to the natives of the Nyanza region in general we are told that "they are persuaded that rain only falls as a result of magic, and the important duty of causing it to descend devolves on the chief of the tribe. If rain does not come

1 E. D. Pruyssenaere, "Reisen und Forschungen im Gebiete des Weissen und Blauen Nil," Petermann's Mittheilungen: Ergänzungsheft, No. 50 (Gotha, 1877), pp. 27 sq.

${ }^{2}$ Sir H. Johnston, op. cit. ii. 555.

3 G. Casati, Ten Years in Equatoria (London and New York, 1891), ii. 57, compare i. 134. 
at the proper time, everybody complains. More than one petty king has been banished his country because of drought." I A Catholic missionary writes that "a superstition common to the different peoples of equatorial Africa attributes to the petty kings of the country the exclusive power of making the rain to fall; in extreme cases the power is ascribed to certain kings more privileged than the rest, such as those of Huilla, Humbe, Vare, Libebe, and others. These kings profit by the superstition in order to draw to themselves many presents of cattle; for the rain must fall after the sacrifice of an ox, and if it tarries, the king, who is never at a loss for excuses to extricate himself from the scrape, will ascribe the failure to the defects of the victim, and will seize the pretext to claim more cattle." 2

In Western as well as in Eastern and Central Africa we find the same union of chiefly with magical functions. Thus in the Fan tribe the strict distinction between chief and medicine-man does not exist. The chief is also a medicine-man and a smith to boot; for the Fans esteem the smith's craft sacred, and none but chiefs may meddle with it. ${ }^{3}$ The head chief of Etatin in Southern Nigeria, like other petty kings in that part of the world, is never allowed to leave his compound, that is, the enclosure in which his house stands. The present incumbent of the office was lately questioned by an English Commissioner, to whom he

1 Mgr. Livinhac, in Annales de la Propagarion de la Foi, 1x. (1888), p. 110.

"Ch. Wunenberger, "La mission et le royaume de Humbé, sur les bords du Cunène," Missions Casholiques, xx. (1888), p. 262.

O. Lenz, Stimen aus Westafrika (Berlin, 87-8), p. 87. 
gave the following account of himself and his duties. He said: "The whole town forced me to be head chief. They hanged our big juju [or fetish] (the buffalo's horns) round my neck. Had I refused, I should have had to give them the value of two slaves. It is an old custom that the head-chief here shall never leave his compound. I have been shut up ten years, but, being an old man, I don't miss my freedom. I am the oldest man of the town, and they keep me here to look after the jujus [or fetishes], and to conduct the rites celebrated when women are about to give birth to children, and other ceremonies of the same kind. By the observance and performance of these ceremonies, I bring game to the hunter, cause the yam crop to be good, bring fish to the fisherman, and make rain to fall. So they bring me meat, yams, fish, etc. To make rain, I drink water, and squirt it out, and pray to our big deities. If I were to go outside this compound, I should fall down dead on returning to this hut. My wives cut my hair and nails, and take great care of the parings." 1 Thus from his own account we see that this West African chief is above all a magician, though he also acts as a priest by offering prayer to the gods.

As to the relation between the offices of chief and rain-maker among the Caffres of South Africa, I will quote a passage from Mr. Dudley Kidd, a recent and well-informed writer on the subject. He says: "In very old days the chief was the great Rain-maker ot the tribe. Some chiefs allowed no one else to compete

1 Ch. Partridge, Cross River Natives (London, 1905), pp. 201 sq. 
with them, lest a successful Rain-maker should be chosen as chief. There was also another reason : the Rain-maker was sure to become a rich man if he gained a great reputation, and it would manifestly never do for the chief to allow any one to be too rich. The Rainmaker exerts tremendous control over the people, and so it would be most important to keep this function connected with royalty. Tradition always places the power of making rain as the fundamental glory of ancient chiefs and heroes, and it seems probable that it may have been the origin of chieftainship. The man who made the rain would naturally become the chief. In the same way, Chaka [the famous Zulu despot] used to declare that he was the only diviner in the country, for if he allowed rivals, his life would be insecure." 1

A letter, dated from Buluwayo, the 2oth of November I 880, records that " the king [of the Matabeles] Lo Bengula arrived yesterday evening at his kraal of 'the White Rocks.' He brought with him the rain to his people. For, according to the ideas of the Matabeles, it is the king who ought to 'make the rain and the good season' in all senses of the word. Now Lo Bengula had chosen well the day and the hour, for it was in the midst of a tremendous storm that the king made his solemn entrance into his capital." "You must know that the arrival of the king and of the rain give rise every year to a little festival. For the rain is the great benefit conferred by the king, the pledge

1 Dudiey Kidd, The Essemtial Kafir (London, 1904), P. 114. 
of future harvests and of plenty, after eight months of desolating drought." To bring down the needed showers the king of the Matabeles boils a magic hellbroth in a huge cauldron, which sends up volumes of steam to the blue sky. But to make assurance doubly sure, he has recourse to religion as well as to magic; for he sacrifices twelve black oxen to the spirits of his fathers and prays to them: "O great spirits of my father and grandfather, I thank you for having granted last year to my people more wheat than to our enemies the Mashonas. This year also, in gratitude for the twelve black oxen which I am about to dedicate to you, make us to be the best-fed and the strongest people in the world!"' Thus the king of the Matabeles acts not only as a magician, but as a priest; for he prays and sacrifices to the spirits of his forefathers, as I had occasion to point out in a former lecture.

The foregoing evidence, somewhat tedious perhaps in its monotony, renders it highly probable that in Africa the king has often been developed out of the public magician, and especially out of the rain-maker. The unbounded fear which the magician inspires and the wealth he often amasses in the exercise of his profession have both contributed to effect his promotion. The miraculous powers ascribed to kings elsewhere are at least consistent with the hypothesis that they too have risen to their present exalted rank from a like lowly origin. Thus the Malays firmly believe that the

1 Father Ch. Croonenberghs, in Annales de la Propagation de la Foi, liii. (1881), pp. 262 sq., 267 sq. 
king possesses a personal influence over the works of nature, such as the growth of the crops and the bearing of fruit-trees. The same prolific virtue is supposed to reside, though in a lesser degree, in his delegates, and even in the persons of Europeans who chance to be in charge of districts. In Selangor, one of the native states of the Malay Peninsula, the success or failure of the rice crops is often attributed to a change of district officers. ${ }^{1}$ Now in the Malay region the link which unites the king or rajah with the magician happens to be unusually plain and conspicuous. That link consists in the regalia. For in some parts at least of the Malay region the regalia are regarded as wonder-working talismans, the possession of which carries with it the right to the throne; if the king loses them, he thereby forfeits the allegiance of his subjects. Moreover, and this is a fact of great significance, the Malay magician owns certain insignia which are said to be exactly analogous to the regalia of the divine king, and even bear the same name. ${ }^{2}$ The inference seems almost inevitable that in the Malay region the regalia of the kings are only the conjuring apparatus of their predecessors the magicians, and that therefore, in this part of the world at least, the magician is the humble grub or chrysalis which in due time bursts and discloses that gorgeous butterfly, the rajah or king.

Nowhere apparently is this view of the regalia as the

W. W. Skeat, Malay Magic (London, 1900), p. 36.

2 W. W. Skeat, op. cir. p. 59. As to the regalia, see further id. pp. 23 $87 . ;$ T. J. Newbold, Palitical and Statissical Accouns of the British Sertlements in she Strairs of Malasca, ii. 193. 
true fount of regal dignity carried to such lengths as in Southern Celebes. Here the royal authority is supposed to be in some mysterious fashion embodied in the regalia, while the princes owe all the power they exercise, and all the respect they enjoy, to their possession of these precious objects. In short, the regalia reign, and the princes are merely their representatives. Hence whoever chances to possess the regalia is regarded by the people as their lawful king. For example, if a deposed monarch contrives to keep the regalia, his former subjects remain loyal to him in their hearts, and look upon his successor as a usurper, who is to be obeyed only in so far as he can exact obedience by force. And on the other hand, in an insurrection the first aim of the rebels is to seize the regalia, for if they can only make themselves masters of them, the authority of the sovereign is gone. Thus the regalia are here fetishes which confer a title to the throne, and control the fate of the kingdom. Houses are built for them to dwell in, as if they were living creatures: furniture, weapons, and even lands are assigned to them. Like the ark of God, they are carried with the army to battle, and on various occasions the people propitiate them, as if they were gods, by prayer and sacrifice and by smearing them with blood. Some of them serve as instruments of divination, or are brought forth in times of public disaster for the purpose of staying the evil, whatever it may be. For example, when plague is rife among men or beasts, or when there is a prospect of dearth, the Bugineese 
bring out the regalia, smear them with buffalo's blood, and carry them about. For the most part these fetishes are heirlooms of which the origin is forgotten; some of them are said to have fallen from heaven. Popular tradition traces the foundation of the oldest states to the discovery or acquisition of one of these miraculous objects-it may be a stone, a piece of wood, a fruit, a weapon, or what not, of a peculiar shape or colour. Often the original regalia have disappeared in course of time, but their place is taken by the various articles of property which were bestowed on them, and to which the people have transferred their pious allegiance. The oldest dynasties have the most regalia, and the holiest regalia consist of relics of the bodies of former princes, which are kept in golden caskets wrapt in silk. At Paloppo, the capital of Loowoo, a kingdom on the coast of Celebes, two toy cannons, with barrels like thin gas-pipes, are regalia : their possession is supposed to render the town impregnable. Other regalia of this kingdom are veiled from vulgar eyes in bark-cloth. When a missionary requested to see them, the official replied that it was strictly forbidden to open the bundle; were he to do so, the earth would yawn and swallow them up. In Bima the principal part of the regalia or public talismans consists of a sacred brown horse, which no man may ride. It is always stabled in the royal palace. When the animal passes the government fort on high days and holidays, it is saluted with the fire of five guns: when it is led to the river to bathe, the royal spear is carried before it, and any man 
who does not make way for the beast, or crosses the road in front of it, has to pay a fine. But the horse is mortal, and when it goes the way of all horse flesh, another steed chosen from the same stud reigns in its place. ${ }^{1}$

The belief that kings and chiefs possess either supernatural powers or wonder-working talismans has left not a few traces of itself in Europe, and even in our own country. The Homeric Greeks thought that the reign of a good king caused the black earth to bring forth wheat and barley, the trees to be loaded with fruit, the flocks to multiply, and the sea to yield fish. ${ }^{2}$ It was a belief of the ancient Irish that when their kings observed the customs of their ancestors, the seasons were mild, the crops plentiful, the cattle fruitful, the waters abounded with fish, and the fruit-trees

1 G. J. Harrebomée, "Een ornamentenfeest van Gantarang (Zuid-Celebes)," Mededeelingen van wege het Nederlandsche Zendelinggenootschap, xix. (1875), pp. 344$35 \mathrm{I}$; G. K. Niemann, "De Boegineezen en Makassaren," Bijdragen tot de TaalLand-en Volkenkunde van Nederlandsch Indiz, xxxviii. (1889), pp. 270 sq.; D. F. van Braam Morris, in Tijdschrift woor Indische Taal-Land-en Volkenkunde, xxxiv. (1891), pp. 215 sq. ; A. C. Kruijt, "Van Paloppo naar Posso," Mededeelingen van wege het Nederlandsche Zendelinggenootschap, xlii. (1898), pp. 18, 25 sq.; L. W. C. van den Berg, " De Mohamedaansche Vorsten in Nederlandsch Indie," Bijdragen tot de TaalLand-en Volkenkunde van Nederlandsch Indië, liii. (1901), pp. 72-80. The Scythian kings treasured as sacred a plough, a yoke, a battle-axe, and a cup, all of gold, which were said to have fallen from heaven : they offered great sacrifices to these sacred things at an annual festival; and if the man in charge of them fell asleep under the open sky, it was believed that he would die within the year. See Herodotus, iv. 5-7. Compare K. Neumann, Die Hellenen im Skythenlande, i. (Berlin, 1855), pp. 269 sq. The crown of the Egyptian kings was treated as itself divine. See A. Moret, Le rituel du culte divin journalier (Paris, 1902), pp. 94 sq.; A. Erman, Die agyptische Religion (Berlin, 1905), p. 40. Among the Yorubas of West Africa a miraculous or fetish virtue seems to be attributed to the royal crown, and the king sometimes sacrifices sheep to it. See Sir William MacGregor, "Lagos, Abeokuta, and the Alake," Fournal of the African Society, No. 12, July 1904, p. 472. The sceptre of Agamemnon was worshipped at Chæronea (Pausanias, ix. 40. I I).

2 Homer, Odyssey, xix. 109-114. 
had to be propped up on account of the weight of their produce. A canon attributed to St. Patrick enumerates among the blessings that attend the reign of a just king "fine weather, calm seas, crops abundant, and trees laden with fruit." 1 Notions of the same sort have lingered in the Highlands of Scotland down to modern times. When Dr. Johnson travelled in Skye, it was still held that the return of the chief of the Macleods to Dunvegan, after any considerable absence, produced a plentiful catch of herring. ${ }^{2}$ To this day the family of the same chief owns a banner which is called "Macleod's Fairy Banner" on account of the supernatural powers ascribed to it. When it is unfurled, victory in war attends it, and it relieves its followers from imminent danger. But these virtues it can exert only thrice, and already it has been twice unfurled. When the potato crop failed, the common people desired that the magical banner might be displayed, ${ }^{3}$ apparently in the belief that the sight of it would produce a fine crop of potatoes. The banner of this highland chief is thus a talisman like the regalia of a Malay rajah.

Again, in the Middle Ages, German mothers offered their infants to Waldemar First, king of Denmark, to be touched by him, believing that the children would thrive the better for the royal touch; and for

I P. W. Joyce, Sarial Hisfory of Anciens Ireland (1.ondon, 1903), i. 56 sq.; J. O'Donovan, The Bock of Righis (Dublin, 1847), p. 8 note.

2 S. Johinson, Journoy to she Wessern Jalands (Battimore, 1815), p. 115.

2 J. G. Campbell, Superasitions of the Highlands and Islands of Srasland (Glangow, $1900 \%$, p. 5. 
a like reason farmers asked him to throw the seed for them. ${ }^{1}$ The English kings claimed the power of curing scrofula by their touch; for which reason the disease was known as the King's Evil. Charles the Second often exercised this miraculous gift of healing, as we know from Pepys, who witnessed the ceremony more than once. Thus on the thirteenth of April I66I he records in his diary: "Met my Lord with the Duke; and after a little talk with him, I went to the Banquet-house, and there saw the king heale, the first time that ever I saw him do it; which he did with great gravity, and it seemed to me to be an ugly office and a simple one." 2 In his childhood Dr. Johnson was touched for scrofula by Queen Anne, and he retained in later life a faint but solemn recollection of her as of a lady in diamonds with a long black hood. ${ }^{3}$ The French kings claimed to possess the same beneficent power, which they are said to have derived from Clovis or St. Louis, while our English kings inherited it from Edward the Confessor. ${ }^{4}$ But probably the barbarous predecessors both of the Saxon and the Merovingian kings had set up similar pretensions long before the dawn of history. Down to last century the West African tribe of the Walos, in Senegal, ascribed

\footnotetext{
1 Saxo Grammaticus, Historia Danica, bk. xiv. p. 779, ed. P. E. Müler.

2 Memoirs of Samuel Pepys, Esq., edited by Lord Braybrook, Second Edition (London, 1828), i. 187 ; compare ib. p. 110 ; iii. 192.

3 J. Boswell, Life of Samuel Fohnson ${ }^{9}$ (London, 1822), i. 18 sq.

4 T. J. Pettigrew, Superstitions connected with the History and Practzce of Medicine and Surgery (London, 1844), p. 117-154; W. E. H. Lecky, History of England in the Eighteenth Century (London, 1892), i. 84-90; W. G. Black, Folk-medicine (London, 1883), pp. 140 sq9.
} 
to their royal family the same power of healing by touch. Mothers have been seen to bring their sick children to the queen, who touched them solemnly with her foot on the back, the stomach, the head, and the legs; then the credulous women went away, persuaded that the children had been made whole. ${ }^{1}$

On the whole, then, we seem to be justified in concluding that in many parts of the world the king is the lineal successor of the old magician or medicine-man. When once a special class of sorcerers has been segregated from the community and entrusted by it with the discharge of duties on which the public safety and welfare are believed to depend, these men gradually rise to wealth and power, till their leaders blossom out into sacred kings. But the great social revolution which thus begins with democracy and ends in despotism is attended by an intellectual revolution which affects both the conception and the functions of royalty. For as time goes on, the fallacy of magic becomes more and more apparent to the acuter minds and is slowly displaced by religion; in other words, the magician gives way to the priest, who, renouncing the attempt to control directly the processes of nature for the good of man, seeks to attain the same end indirectly by appealing to the gods to do for him what he no longer fancies he can do for himself. Hence the king, starting as a magician, tends gradually to exchange the practice of magic for the priestly functions of prayer

'Baron Roger, "Notice sur le gouvernement, les maurs et les superstitions des Niegrea du pays de Walo," Bullerin de la Sosilte de Géographie (Pario), viii. (1827) p. 35 . 
and sacrifice. And while the distinction between the human and the divine is still imperfectly drawn, it is often imagined that men may themselves attain to godhead, not merely after their death, but in their lifetime, through the temporary or permanent possession of their whole nature by a great and powerful spirit. No class of the community has benefited so much as kings by this belief in the possible incarnation of a god in human form. The doctrine of that incarnation, and with it the theory of the divinity of kings in the strict sense of the word, will form the subject of the next lecture. 


\section{LECTURE V}

Development of the magician into a god as well as a king-Incarnate human gods in Polynesia, Africa, and ancient Greece and Germany-Worship of the Brahmans in India-Human gods in Tibet and China-Divinity of the emperors of China and Japan-Worship of the kings of Babylon and EgyptSummary of the evolution of the Kingship-King of the Wood at $\mathrm{Nemi}$ again considered-He seems to have been the mate of Diana, the two being considered as King and Queen of the Wood-Trees regarded as male and female-Marriages of trees and plants.

Is the preceding lectures we saw grounds for thinking that in some parts of the world the public magician has often developed into a chief or king, partly through the terror which his reputed skill inspires, partly through the wealth which he gains in the exercise of his profession. Even among tribes such as the Australians and Papuans, who are too rude to have evolved a regular chieftainship or kingship, we detected some symptoms of the gravitation of political power towards the magicians or medicine-men. Among the American Indians the furthest advance towards civilisation was made under the monarchical and theocratic governments of Mexico and Peru; but we know too little of the early history of these countries to say whether the 
predecessors of their deified kings were medicine-men or not. However, among some of the savage Brazilian Indians at the time of the discovery of America, the sorcerer appears to have been treated with a respect which might in time have raised him to the rank of a divine king, if the course of evolution had not been cut short by the intervention of Europeans. Thus one of the earliest settlers on the coast of Brazil, the Frenchman Thevet, reports that the Indians "hold these pages (or medicine-men) in such honour and reverence that they adore, or rather idolatrise them. You may see the common folk go to meet them, prostrate themselves, and pray to them, saying, 'Grant that I be not ill, that I do not die, neither I nor my children,' or some such request. And he answers, 'You shall not die, you shall not be ill,' and such like replies. But sometimes if it happens that these pages do not tell the truth, and things turn out otherwise than they predicted, the people make no scruple of killing them as unworthy of the title and dignity of pages." 1

Among these Indians the magician is, or rather was, plainly on the high road to become a living god as well as a king. To the mind of a savage the distinction between a powerful sorcerer and a god seems not to be a sharp one. His gods are often merely invisible magicians who behind the veil of nature work the same sort of charms and incantations which the human

1 F. A. Thevet, Les singularitez de la France Antarctique, autrement nommée Amérique (Antwerp, 1558), p. 65 [wrongly numbered 67]. 
magician works in a visible and bodily form among his fellows. And as the gods are commonly believed to exhibit themselves in the likeness of men to their worshippers, it is easy for the magician, with his supposed miraculous powers, to acquire the reputation of being an incarnate deity. Thus beginning as little more than a simple conjurer, the medicine-man or magician tends to blossom out into a full-blown god and king in one. Only in speaking of him as a god we must beware of importing into the savage conception of deity those very abstract and complex ideas which we attach to the term. Our ideas on this profound subject are the fruit of a long intellectual and moral evolution, and they are so far from being shared by the savage that he cannot even understand them when they are explained to him. Much of the controversy which has raged as to the religion of the lower races has sprung merely from a mutual misapprehension. The savage does not understand the thoughts of the civilised man, and few civilised men understand the thoughts of the savage. When the savage uses his word for god, he has in his mind a being of a certain sort: when the civilised man uses his word for god, he has in his mind a being of a very different sort; and if, as commonly happens, the two men are equally unable to place themselves at the other's point of view, nothing but confusion and mistakes on both sides can result from their discussions. If we civilised men insist on limiting the name of God to that particular conception of the divine nature which we ourselves have formed, then we 
must confess that the savage has no god at all. But we shall adhere more closely to the facts of history if we allow most of the higher savages at least to possess a rudimentary notion of certain supernatural beings who may fittingly be called gods, though not in the full sense in which we use the word. That rudimentary notion represents in all probability the germ out of which the civilised peoples have gradually evolved their own high conceptions of divinity; and if we could trace the whole course of religious development we might find that the chain which links our idea of the Godhead with that of the savage was one and unbroken.

With these explanations I shall now give you some instances of gods who are believed by their worshippers to be incarnate in living human beings, whether men or women. The persons in whom a deity is thought to reveal himself are by no means always kings or descendants of kings; the supposed incarnation may take place even in men of the humblest rank. I shall therefore not draw my examples exclusively from royal personages, as I wish to illustrate what we may call the general principle of the deification of living men, in other words, the incarnation of a deity in human form.

Thus, for example, a Catholic missionary, writing some sixty years ago, tells us that the natives of Futuna, an island in the South Pacific, "are not content with deifying the evils that afflict them : they place gods everywhere, and even go so far as to suppose that the greatest of all the spirits resides in the person of their 
prince as in a living sanctuary. From this belief springs a strange mode of regarding their king, and of behaving under his authority. In their eyes the sovereign is not responsible for his acts : they deem him inspired by the divine spirit whose tabernacle he is: hence his will is sacred: even his whims and rages are revered; and if it pleases him to play the tyrant, his subjects submit from conscientious motives to the vexations he inflicts on them." 1

An early Portuguese historian informs us that the king of Sofala, in south-eastern Africa, " is a woollyhaired Kaffir, a heathen who adores nothing whatever, and has no knowledge of God; on the contrary, he esteems himself the god of all his lands, and is so looked upon and reverenced by his subjects." "When they suffer necessity or scarcity they have recourse to the king, firmly believing that he can give them all that they desire or have need of, and can obtain anything from his dead predecessors, with whom they believe that he holds converse. For this reason they ask the king to give them rain when it is required, and other favourable weather for their harvest, and in coming to ask him for any of these things they bring him valuable presents, which the king accepts, bidding them return to their homes, and he will be careful to grant their petitions. They are such barbarians that though they see how often the king does not give them what they ask for, they are not undeceived, but make him still

\footnotetext{
2 Missionary Chevron, in Annales de la Propagation de la Fai, xv. $\left(1 \$_{43}\right)$, p. 37. Compare id. xiii. $(18+1)$, p. 378 .
} 
greater offerings, and many days are spent in these comings and goings, until the weather turns to rain, and the Kaffirs are satisfied, believing that the king did not grant their request until he had been well bribed and importuned, as he himself affirms, in order to maintain them in their error." 1 Again, the same early Portuguese historian writes that the Zimbas, or Muzimbas, another people of south-eastern Africa, "do not adore idols or recognise any god, but instead they venerate and honour their king, whom they regard as a divinity, and they say that he is the greatest and best in the world. And the said king says of himself that he alone is god of the earth, for which reason if it rains when he does not wish it to do so, or is too hot, he shoots arrows at the sky for not obeying him." 2 The Maraves of South Africa have, or had at least some seventy years ago, " a spiritual head to whom they ascribe supernatural powers, revering him as a prophet and designating him by the name of Chissumpe. Besides a considerable territory, which he owns and rules, he receives tribute from all, even from the king. They believe that this being is invisible and immortal, and they consult him as an oracle, in which case he makes himself heard. He is personified by a substitute, whose dignity is hereditary and who is revered exactly like the supposed Chissumpe, with whom he is naturally identical. As he names his own successor, disputes as to the succession do not arise. His oracles are as unintelligible and ambiguous

1 J. Dos Santos, "Eastern Ethiopia," in G. M'Call Theal's Records of SouthEastern Africa, vii. (1901), pp. 190 sq., 199.

2 J. Dos Santos, op. cit. p. 295. 
as can well be imagined. He derives great profit from impostors of both sexes, who purchase the gift of soothsaying from him." 1

In the Makalaka hills, to the west of Matabeleland, there lives a human god. The account of him which I shall quote was published in a Catholic missionary journal some quarter of a century ago. This man-god "resides in the depth of a cave, in the midst of a labyrinth. Nobody has ever seen him, but he has sons and daughters, who are priests and priestesses, and dwell in the neighbourhood of the grotto. It is rather odd that not long ago three sons of this god were put to death like common mortals for having stolen wheat from the king. Lo Bengula [the king of the Matabeles] probably thought that they should practise justice even more strictly than other folk. . . . In the middle of the (oracular) cavern, they say, there is a shaft, very deep and very black. From this gulf there issue from time to time terrible noises like the crash of thunder. On the edge of the abyss the worshippers tremblingly lay flesh and wheat, fowls, cakes, and other presents to appease the hunger of the dreadful god and secure his favour. After making this offering the poor suppliants declare aloud their wishes and the object of their application. They ask to know hidden things, future events, the names of those who have cast a spell on them, the

1 Zeitschrifs for Allgemeine Erdkunde, vi. (1856), pp. 273 sq. This is from a German abstract of a work which embodies the results of a Portuguese expedition conducted by Major Monteiro in $183_{1}$ and 1832 . The territory of the Maraves is described as bounded on the south by the Zambesi and on the east by the Portuguese possessions. Probably thing have changed greatly in the seventy years which have elapsed since the expedition. 
issue of such and such an enterprise. After some moments of profound silence there are heard, amid the crash of subterranean thunder, inarticulate sounds, broken words, of which it is hard to make out the sense, and which the medicine-men, who are hand in glove with the makers of thunder, explain to these credulous devotees." 1

The Mashonas of South Africa have also a human god, who does not wrap himself up in such a profound mystery as the one I have just described. He was formerly bound to render an annual tribute to the king of the Matabeles in the shape of four black oxen and one dance. A missionary has seen and described the deity discharging the latter part of his duty in front of the royal hut. For three mortal hours without a break, to the banging of a tambourine, the click of castanets, and the drone of a monotonous song, the swarthy god engaged in a frenzied dance, crouching on his hams like a tailor, sweating like a pig, and bounding about with an agility which testified to the strength and elasticity of his divine legs. ${ }^{2} \quad$ The Sakalavas in the north of Madagascar revere a sovereign whom they call Zanahari antani, "God on earth." $\mathrm{He}$ is treated by them with a veneration which resembles idolatry, and the vulgar are simple enough to attribute the creation of the world to his ancestors. His person and property are sacred, and the different parts of his body and his least actions are described by nouns and verbs which are foreign to

1 Annales de la Propagation de la Foi, lii. (1880), pp. 443-445.

2 Father Croonenberghs, "La mission du Zambèze," Missions Catholiques, xiv. (1882), pp. $45^{2}$ sq. 
the ordinary language, forming a separate vocabulary known as sacred or princely words. ${ }^{1}$

The deification of living men was not unknown in ancient Greece. Thus the philosopher Empedocles gave himself out to be not merely a wizard but a god. Addressing his fellow-citizens in verses which I will translate, he said :

O friends, in this great city that climbs the yellow slope

Of Agrigentum's citadel, who make good zoorks your scope, Who offer to the stranger a haven quiet and fair, All hail! Among you honoured I walk with lofty air. With garlands, blooming garlands, you crown my noble brow, A mortal man no longer, a deathless godhead now.

Where'er I go, the people crosvd round and worship pay, And thousands follow seeking to learn the better way. Some crave prophetic vision, some smit with anguish sore Would fain hear words of comfort and suffer pain no more.

He asserted that he could teach his disciples how to make the wind to blow or be still, the rain to fall and the sun to shine, how to banish sickness and old age, and to raise the dead. ${ }^{2}$ When Demetrius Poliorcetes restored the Athenian democracy in 307 B.c., the Athenians decreed divine honours to him and to his father Antigonus, both of them being then alive. The two new deities received the title of the Saviour Gods. Altars were set up to them, and a priest was appointed to attend to their worship. The people went forth to meet Demetrius, the Saviour, with hymns and

1 V. Noel, "Ile de Madagascar : recherches sur les Sakkalava," Bullesin de la Saciété de Géographie (Paris), Deuxième Série, xx. (1843), p. 56.

2 Diogenes Laertius, Vis. Philosoph. viii. 59-62 ; Fragmenta Philosophorwm Grace corum, ed. F. G. A. Mullach, i. pp. 12, 14 ; H. Diels, Die Fragmenee der Vorsokra. siker (Berlin, 1903), pp. 214 sq. 
dances, with garlands and incense and libations : they lined the streets and sang that he was the only true god, for the other gods slept, or dwelt far away, or were not. In the words of a contemporary poet, which were chanted in public and sung in private :

Of all the gods the greatest and the dearest

To the city are come.

For Demeter and Demetrius

Together time has brought.

She comes to hold the Maiden's awful rites, And he joyous and fair and laughing, As befits a god.

A glorious sight, with all his friends about him, $\mathrm{He}$ in their midst, They like to stars, and he the sun.

Son of Poseidon the mighty, Aphrodite's son, All hail!

The other gods dwell far away,

Or have no ears,

Or are not, or pay us no heed.

But thee we present see,

No god of wood or stone, but godhead true.

Therefore to thee we pray. ${ }^{1}$

The ancient Germans believed that there was something holy in women, and accordingly they consulted them as oracles. Their sacred women, we are told, looked on the eddying rivers and listened to the murmur or the roar of the water, and from the sight and sound foretold what should come to pass. But often the veneration of the men went further, and they worshipped women as true and living goddesses. For example, in the reign of Vespasian a certain Veleda, of the

1 Plutarch, Demetrius, 10-13 ; Athenaeus, vi. pp. 253 sq. 
tribe of the Bructeri, was commonly held to be a deity, and in that character she reigned over her people, her sway being acknowledged far and wide. She lived in a tower on the river Lippe, a tributary of the Rhine. When the people of Cologne sent to make a treaty with her, the ambassadors were not admitted to her presence: the negotiations were conducted through a minister, who acted as the mouthpiece of her divinity and reported her oracular utterances. ${ }^{1} \quad$ This example shows how easily among our own rude forefathers the ideas of divinity and royalty coalesced.

At the present day the head of the great Persian sect of the Babites, Abbas Effendi by name, resides at Acre in Syria, and is held by Frenchmen, Russians, and Americans, especially by rich American ladies, to be an incarnation of God himself. The late Professor S. I. Curtiss of Chicago had the honour of dining with "the Master," as he is invariably called by his disciples, and the deity expressed a kindly hope that he might have the pleasure of drinking tea with the professor in the kingdom of heaven. ${ }^{2}$

But perhaps no country in the world is so prolific of human gods as India. The ancient Indian code known as the Laws of Manu lays it down that a Brahman, " be he ignorant or learned, is a great divinity, just as the fire, whether carried forth (for the performance of a burnt oblation) or not carried forth, is a great divinity." Further it is said in the same code that though Brahmans

\footnotetext{
1 Tacitus, Germania, 8; id., Hisfor. iv. 61, 65, v. 22. Compare K. Müllenhoff, Deursche Aliertumskunde, v. 208 sqg.

2 S. I. Curtiss, Primirive Semitic Religicn ro-day (Chicago, 1902), p. 102.
} 
"employ themselves in all sorts of mean occupations, they must be honoured in every way; for each of them is a very great deity." 1 And in another ancient Hindoo treatise we read that "verily, there are two kinds of gods; for, indeed, the gods are the gods; and the Brahmans who have studied and teach sacred lore are the human gods. The sacrifice of these is divided into two kinds : oblations constitute the sacrifice to the gods ; and gifts to the priests that to the human gods, the Brahmans who have studied and teach sacred lore."2 As to the mantras, or sacred texts by means of which the Brahmans exert their miraculous powers, there is a saying everywhere current in India, "The whole universe is subject to the gods; the gods are subject to the Mantras ; the Mantras to the Brahmans ; therefore the Brahmans are our gods." 3

At Chinchvad, a small town about ten miles from Poona in western India, there lives a family of whom one in each generation is believed by a large proportion of the Mahrattas to be an incarnation of the elephantheaded god Gunputty. That celebrated deity was first made flesh about the year 1640 in the person of a Brahman of Poona, by name Mooraba Gosseyn, who sought to work out his salvation by abstinence, mortification, and prayer. His piety had its reward. The god himself appeared to him in a vision of the night and promised that a portion of his, that is, of Gunputty's,

1 The Laws of Manu, ix. $\S \S 317,319$, pp. 398, 399, translated by G. Bühler.

2 Satapatha-Brahmâna, translated by J. Eggeling, Part i. pp. 309 sq.; compare id. Part ii. p. 341 .

3 Monier Williams, Religious Life and Thought in India, pp. 201 sq. 
holy spirit should abide with him and with his seed after him even to the seventh generation. The divine promise was fulfilled. Seven successive incarnations, transmitted from father to son, manifested the light of Gunputty to a dark world. The last of the direct line, a heavy-looking god with very weak eyes, died in the year I 8 ro. But the cause of truth was too sacred, and the value of the church property too considerable, to allow the Brahmans to contemplate with equanimity the unspeakable loss that would be sustained by a world which knew not Gunputty. Accordingly they sought and found a holy vessel in whom the divine spirit of the Master had revealed itself anew, and the revelation has been happily continued in an unbroken succession of vessels from that time to this. But a mysterious law of spiritual economy, whose operation in the history of religion we may deplore though we cannot alter, has decreed that the miracles performed by the god-man in these later days cannot compare with those which were wrought by his predecessors in days gone by; and it is even reported that the only sign now vouchsafed by him is the miracle of feeding the multitude, whom he annually entertains to dinner at Chinchvad. ${ }^{1}$ To be exact, I should say that I have no information as to this particular deity later than the account of him in the eighteenth volume

1 Captain Edward Moor, "Account of an hereditary living deity," Asiatic Researches, vii. $3^{81-395}$ (8vo edition); Viscount Valentia, Voyages and Travels, ii. 151-159; Ch. Coleman, Myshology of the Hindus (London, 1832), pp. 106-111; Gazessecr of the Bombay Presidengy, xviii. Part iii. (Bombay, 1885), pp. 125 sg. I have to thank Mr. W. Crooke for calling my attention to the second and fourth of these works. 
of the Bombay Gazetteer, published some twenty years ago. But I think we may assume that the same providential reasons which prolonged the revelation down to the publication of the Gazetteer have continued it to the present day.

We are all familiar with the great incarnate god of Lhassa, the Dalai Lama, who has lately fallen from his high estate before the carnal weapons of his Majesty's troops. In the year I66I or I662 Fathers Grueber and d'Orville, on their return from Peking to Europe, spent two months at Lhassa, waiting for a caravan, and they report that the Grand Lama was worshipped as a true and living god, that he received the title of the Eternal and Heavenly Father, and that he was believed to have risen from the dead not once but seven times. He lived withdrawn from the business of this passing world in the recesses of his palace, where, seated aloft on a cushion and precious carpets, he received the homage of his adorers in a chamber screened from the garish eye of day, but glittering with gold and silver, and lit up by the blaze of a multitude of torches. ${ }^{1}$

But he is by no means the only man who poses as a god in these regions. A register of all the incarnate gods in the Chinese Empire is kept in the Li fan yüan or Colonial Office at Peking. The number of gods who have thus taken out a license is one hundred and sixty. Tibet rejoices in thirty of them, and northern Mongolia in nineteen, while southern Mongolia is

\footnotetext{
1 Thevenot, Relations de divers voyages, iv. Partie (Paris, 1672), "Voyage à la Chine des PP. I. Grueber et d'Orville," pp. I sq., 22.
} 
blessed with no less than fifty-seven. The Chinese Government, with a paternal solicitude for the welfare of its subjects, forbids the gods on the register to be reborn anywhere but in Tibet. They fear lest the birth of a god in Mongolia should have serious political consequences by stirring the dormant patriotism and warlike spirit of the Mongols, who might rally round an ambitious native deity of royal lineage, and might seek to win for him, at the point of the sword, a temporal as well as a spiritual kingdom. But besides these public or licensed gods, there are a great many little private gods, or unlicensed practitioners of divinity, who work miracles and bless their people in holes and corners ; and of late years the Chinese Government has winked at the rebirth of these pettifogging deities outside of Tibet. However, once they are born the Government keeps its eye on them as well as on the regular practitioners, and if any of them misbehaves, he is promptly degraded, banished to a distant monastery, and strictly forbidden ever to be born again in the flesh. ${ }^{1}$

At the head of Taoism, the most numerous religious sect of China, is a pope who goes by the name of the Heavenly Master, and is believed to be an incarnation and representative on earth of the god of heaven. His official title is Chên-yen, or " the True Man." When one of these pontiffs or incarnate deities departs this life, his soul passes into a male member of his family,

1 E. Pander (Professor at the University of Peking). "Das lamaische Pantheon," Zeitschrift für Ethnologie, xxi. (1889), p. 76 ; id. "Geschichte des Lamaismus," Verhandlungen der Berlemer Gesellschaft fir Anthropologie, Ethnologie und Urgeschichie. 1889, p. (202). 
the ancient house of Chang. In order to determine his successor, all the male members of the clan assemble at the palace, their names are engraved on tablets of lead, the tablets are thrown into a vessel full of water, and the one which bears the name of the new incarnation floats on the surface. The reputation and power of the pope are very great. He lives in princely style at his palace on the Dragon and Tiger mountains in the province of Kiang-si, about twenty-five miles to the southwest of Kuei-ki. The road, which is provided at regular intervals with stone halls for the repose of weary pilgrims, leads gradually upward through a bleak and barren district, treeless and thinly peopled, to the summit of a pass, from which a beautiful prospect suddenly opens up of a wide and fertile valley watered by a little stream. The scene charms the traveller all the more by contrast with the desert country which he has just traversed. This is the beginning of the pope's patrimony, which he holds from the emperor free of taxes. The palace stands in the middle of a small town. It is new and of no special interest, having been rebuilt after the Taiping rebellion. For in their march northward the rebels devastated the papal domains with great fury. About a mile to the east of the palace lie the ruins of stately temples, which also perished in the great rising and have only in part been rebuilt. However, the principal temple is well preserved. It is dedicated to the god of heaven, and contains a colossal image of that deity. The papal residence naturally swarms with monks and priests of all ranks. But the courts and 
gardens of the monasteries, littered with heaps of broken bricks and stones and mouldering wood, present a melancholy spectacle of decay. And the ruinous state of the religious capital reflects the decline of the papacy. The number of pilgrims has fallen off; and with them the revenues of the holy see. Formerly the pope ranked with viceroys and the highest dignitaries of the empire : now he is reduced to the level of a mandarin of the third class, and wears a blue button instead of a red. Formerly he repaired every year to the imperial court at Peking or elsewhere in order to procure peace and prosperity for the whole kingdom by means of his ceremonies; and on his journey the gods and spirits were bound to come from every quarter to pay him homage, unless he considerately hung out on his palanquin a board with the notice, "You need not trouble to salute." The people, too, gathered up the dust or mud from under his feet to preserve it as a priceless talisman. Nowadays, if he goes to court at all, it seems to be not oftener than once in three years; and his services are seldom wanted except to ban the demons of plague. But he still exercises the right of elevating deceased mandarins to the rank of local deities, and as he gets a fee for every deification, the ranks of the celestial hierarchy naturally receive many recruits. He also draws a considerable revenue from the manufacture and sale of red and green papers inscribed with cabalistic characters, which are infallible safeguards against demons, disease, and calamities of every kind. ${ }^{1}$

1 Mgr. Danicourt, "Rapport sur l'origine, les progrès et la decadence de la sccte 
However, in China the greatest of all human gods is the emperor. As to the position which he occupies in the minds of the people, I will quote the words of Professor J. J. M. de Groot, of Leyden, the most eminent living authority, I believe, on Chinese religion. He says : "To no son of China would it ever occur to question the supreme power wielded by the emperor and his proxies, the mandarins, not only over mankind, but also over the gods. For the gods or shen are souls of intrinsically the same nature as those existing in human beings; why then, simply because they have no human bodies, should they be placed above the emperor, who is no less than a son of Heaven, that is to say, a magnitude second to none but Heaven or the Power above whom there is none-who governs the universe and all that moves and exists therein? Such absurdity could not possibly be entertained by Chinese reason. So it is a first article of China's political creed that the emperor, as well as Heaven, is lord and master of all the gods, and delegates this dignity to his mandarins, each in his jurisdiction. With them then rests the decision which of the gods are entitled to receive the people's worship, and which are not. It is the imperial government which deifies disembodied souls of men, and also divests them of their divine rank. Their worship, if established against its will or without its consent, can be exterminated at its pleasure, without

des Tao-sse, en Chine," Annales de la Propagation de la Foi, xxx. (1858), pp. x 5-20; J. H. Gray, China (London, 1878), i. 103 sq.; Dr. Merz, "Bericht uber seine erste Reise von Amoy nach Kui-kiang," Zeitschrift der Gcsellschaft fïr Erdkund: zu Berlin, xxiii. (1888), pp. 413-416. 
revenge having to be feared from the side of the god for any such radical measure; for the power of even the mightiest and strongest god is as naught compared with that of the august Celestial Being with whose will and under whose protection the Son [that is, the Emperor] reigns supreme over everything existing below the empyrean, unless he forfeits this omnipotent support through neglect of his imperial duties." 1

As the emperor of China is believed to be a Son of Heaven, so the emperor of Japan, the Mikado, is supposed to be an incarnation of the sun goddess, the deity who rules the universe, gods and men included. Once a year all the gods wait upon him and spend a month at his court. During that month, the name of which means "without gods," no one frequents the temples, for they are believed to be deserted. ${ }^{2}$

The early Babylonian kings, from the time of Sargon I. till the fourth dynasty of $\mathrm{Ur}$ or later, claimed to be gods in their lifetime. The monarchs of the fourth dynasty of $\mathrm{Ur}$ in particular had temples built in their honour : they set up their statues in various sanctuaries and commanded the people to sacrifice to them: the eighth month was especially dedicated to the kings, and sacrifices were offered to them at the new moon and on the fifteenth day of each month. ${ }^{3}$

1 J. J. M. de Groot, Sectarianism and Religious Persecurion in China, i. (Amtterdan, 8903), pp. 87 sg.

a Marners and Customs of the Fapanese in the Nineteenth Century: from recent Dusch visisers to Japan and the German of Dr. Ph. Fr. von Siebold (London, 1841), Pp. 14 i 49.

3. Radau, Early Babylonian Hissory (New York and London, 8900), Pp. 30\%. 317. Compare C. Brockelmann, "Wesen und Uroprung des Eponymats in 
The ancient kings of Egypt also were worshipped as gods in their lifetime. On this subject the late Sir Peter le Page Renouf says: "It has never been doubted that the king claimed actual divinity; he was the 'great god,' the 'golden Horus,' and son of $\mathrm{Ra}$ [the sun-god]. He claimed authority not only over Egypt, but over 'all lands and nations,' ' the whole world in its length and its breadth, the east and the west,' 'the entire compass of the great circuit of the sun,' ' the sky and what is in it, the earth and all that is upon it,' 'every creature that walks upon two or upon four legs, all that fly or flutter, the whole world offers her productions to him.' Whatever in fact might be asserted of the sun-god was dogmatically predicable of the king of Egypt. His titles were directly derived from those of the sun-god." 1 To quote now a recent French writer who has devoted a special treatise to the investigation of the sacred character of the Egyptian kings. "In the course of his existence," says M. Moret, "the king of Egypt exhausted all the possible conceptions of divinity which the Egyptians had framed for themselves. A superhuman god by his birth and by his royal office, he became the deified man after his death. Thus all that was known of the divine was summed up in him." 2 "The divinity of

Assyrien," Zeitschrift für Assyriologie, xvi. (1902), p. 394; H. Zimmern, in E. Schrader's Die Keilinschriften und das Alte Testament ${ }^{3}$ (Berlin, 1903), pp. 379. $639 \mathrm{sq}$.

1 P. le P. Renouf, "The priestly character of the earliest Egyptian civilisation," Proceedings of the Society of Biblical Archaology, xii. (1890), p. 355.

2 A. Moret, Du caractère religieux de la Rojauté Pharannique (Paris, 1902), pp. 278 sq.; compare p. 313 . 
the king was recognised in all the circumstances of the public life of the sovereign. It was not enough to worship Pharaoh in the temple; beyond the limits of the sanctuary he remained the 'good god' to whom all men owed a perpetual adoration. The very name of the sovereign was sacred like his person; people swore by his name as by that of the gods, and he who took the oath in vain was punished." I In particular, the king of Egypt was identified with the great sun-god Ra. "Son of the sun, decked with the solar crowns, armed with the solar weapons, gods and men adored him as $\mathrm{Ra}$, defended him as $\mathrm{Ra}$ from the attacks which menaced in him the divine being who, in his human existence, knew the glory and the dangers of being 'an incarnate sun' and 'the living image on earth of his father Tum of Heliopolis." " 2 Even the life of the gods depended on the divine life of the king. Gods and men, it was said, "live by the words of his mouth." $s$ "O gods," said the king before celebrating divine worship, "you are safe if I am safe. Your doubles are safe if my double is safe at the head of all living doubles. All live if I live." 4

We have now completed our sketch, for it is no more than a sketch, of the evolution of that sacred kingship which attained its highest form, its most absolute expression, in the monarchies of Peru and Egypt, of China and Japan. Historically, the institu-

\footnotetext{
A. Moret, op. cir. p. 306.

3 A. Moret, op. cir. p. 299.

2 A. Moret, op. cir. p. 310.

4 A. Moret, op. sir. p. 233.
} 
tion appears to have originated in the order of public magicians or medicine-men : logically, it rests on a mistaken deduction from the association of ideas. Men mistook the order of their ideas for the order of nature, and hence imagined that the control which they have, or seem to have, over their thoughts, permitted them to exercise a corresponding control over things. The men who for one reason or another, on the ground of the strength or the weakness of their natural parts, were supposed to possess these magical powers in the highest degree, were gradually marked off from their fellows and became a separate class, who were destined to exercise a most far-reaching influence on the political, religious, and intellectual evolution of mankind. Social progress, as we know, consists mainly in a successive differentiation of functions, or, in simpler language, a division of labour. The work which in primitive society is done by all alike and by all equally ill, or nearly so, is gradually distributed among different classes of workers and executed more and more perfectly; and so far as the products, material or immaterial, of this specialised labour are shared by all, the whole community benefits by the increasing specialisation. Now magicians or medicine-men appear to constitute the oldest artificial or professional class in the evolution of society. ${ }^{1}$ For sorcerers are found in every

1 In regard to the natives of the western islands of Torres Straits it has been remarked by Dr. A. C. Haddon that the magicians or sorcerers "constituted the only professional class among these democratic islanders" (Reports of the Cambridge Anthropological Expedition to Torres Straits, v. 321). The same observation could be applied to many other savage tribes. 
savage tribe known to us; and among the lowest savages, such as the Australian aborigines, they are the only artificial class that exists. As time goes on, and the process of differentiation continues, the order of medicine-men is itself subdivided into such classes as the healers of disease, the makers of rain, and so forth ; while the most powerful member of the order wins for himself a position as chief and gradually develops into a sacred king, his old magical functions falling more and more into the background and being exchanged for priestly or even divine duties, in proportion as magic is slowly ousted by religion. Still later, a partition is effected between the civil and the religious aspect of the kingship, the temporal power being committed to one man and the spiritual to another. Meanwhile the magicians, who may be repressed but are never extirpated by the predominance of religion, still addict themselves to their old occult arts in preference to the newer ritual of sacrifice and prayer; and in time the more sagacious of their number perceive the fallacy of magic and hit upon a more effectual mode of manipulating the forces of nature for the benefit of man ; in short, they abandon sorcery for science. I am far from affirming that the course of development has everywhere rigidly followed these lines: it has doubtless varied greatly in different societies: I merely mean to indicate in the broadest outline what I conceive to have been its general trend. Regarded from the industrial point of view, the evolution has been from uniformity to diversity of function : regarded from the political point of view, it has been 
from democracy to despotism. With the later history of monarchy, especially with the decay of despotism and its displacement by forms of government better adapted to the higher needs of humanity, we are not concerned in these lectures: our subject is the growth, not the decline, of a great and, in its time, beneficent institution.

But if we have thus traced in outline the early history of the kingship, we have still to fill in the details. To do so fully would far exceed not only the time at our disposal but my knowledge and abilities. The task will need the co-operation of many workers. The materials for the history have still in large measure to be collected, sifted, and arranged. In what remains of these lectures I shall confine myself to putting before you some special aspects of the kingship, particularly of the kingship in classical antiquity.

You will remember that we began our inquiry by considering an individual instance of a sacred king, namely, the priest of Diana, known as the King of the Wood, at Nemi. I said that apart from the greater definiteness and precision attained by starting from concrete facts rather than from general ideas, the priesthood of Nemi offers some special advantages, because it raises certain questions of great interest, which will repay investigation. I propose therefore to reconduct you to Nemi for a few minutes before starting on another, though much more narrowly limited, tour of observation.

A review of the classical evidence alone, without any 
application of the comparative method in the wider sense, led us to conclude that the priest of Diana at Nemi represented in the flesh a certain mysterious mythical being named Virbius, who was said to have been the first King of the Wood, and to have been to Diana what Attis was to Cybele or Adonis to Venus. From this it seems necessarily to follow that the priest himself, as the representative of Virbius, stood in the very same relation to the goddess, and as the relation was that of a mortal lover to an immortal goddess, we conclude that the priest was regarded as the mate or consort of Diana.

Now our survey of divine kings and other human incarnations of deities has probably prepared you to admit that the King of the Wood at Nemi may well have been something more than a mere priest, that he may have been supposed to embody, as well as to represent, the mythical being Virbius; in short, that he may have posed as a god as well as a king, and that his predecessors may have attained to that exalted position by the exercise of those magical functions which have so often paved the way to kingship and godhead. If that were so, he would be no unsuitable mate for a goddess. Now Diana at Nemi was called the Lady of the Woods (Nemorensis), while her priest bore the title of Lord or King of the Wood (Rex Nemorensis). When we take this into consideration along with the story of Virbius and his representation by the priest, we seem justified in inferring that the priest and the goddess passed in popular estimation for a loving 
couple, the King and Queen, or Lord and Lady of the Woods.

At this point I would remind you that the priest of Nemi not only bore a title which connected him with the woods in general or at least with the sacred grove in particular, but that, further, he stood in a peculiar relation to one individual tree in the grove, since he might only be attacked by a candidate for office who had broken a bough from that tree. Taken together with his sylvan title and his intimate association with the goddess of the grove, this circumstance may perhaps, without undue straining, be interpreted to mean that his life was in a manner bound up with that of the tree, or to put it in another form, that he was a human representative or incarnation of a tree-spirit. And in regard to his divine partner, Diana, so far as she was a goddess of the woods, it is probable that she was the lineal descendant of a tree-nymph ; for primitive man ascribes an individual spirit, whether a nymph or a faun, to each single tree long before he arrives at the general conception of a god or goddess of the woods.

Now I am not going to inflict upon you a tedious dissertation on tree-worship, but there is one side or aspect of tree-worship to which I must direct your attention, if we are fully to understand the King and Queen of the Wood at Nemi. That side or aspect is the personification of the spirits of trees and plants as male and female respectively. Such a personification, as you are no doubt aware, is not purely fanciful, for plants as well as animals have their sexes. How far the 
real distinction of male and female plants has been observed by savages I am not prepared to say. It is asserted that the Maoris have observed it, and that they have separate names for the different sexes of some trees. $^{1}$ However that may be, it is certain that the ancients had made the discovery: Pliny says that naturalists distinguished the sexes of all trees and plants. And they turned the discovery to practical account in the cultivation of the date-palm by fertilising the tree artificially. ${ }^{2}$ Among the Sabæans of Harran the month during which the palms were thus fertilised bore the name of the Date Month, and at this time they celebrated the marriage festival of all the gods and goddesses. $^{3}$ Many of you may have noticed in the British Museum the great sculptured slabs from Assyria on which a winged figure is represented standing in front of a tree and holding in his hand what looks like a pine-cone. The scene has been ingeniously explained by Professor E. B. Tylor as the artificial fertilisation of the palm. ${ }^{4}$

Different, however, from such true and fruitful marriages of trees are the false and barren marriages which have played a part in the popular superstitions of various lands. These latter are certainly to be attri-

1 Elsdion Best, "Maori Nomenclature," Fournal of the Anshropological Inssisure, xxxii. (1902), p. 197.

2 Herodotus, i. 193 ; Theophrastus, Historia Plantarum, ii. 8. 4 ; Pliny, Niat. Hist. xiii. 3 s, 34 sq.

D. Chwolsohn, Die Ssabier und der Ssabismus, ii. 26, 25 1.

4 E. B. Tylor, in Procecdings of the Sociery of Biblical Archaelugy, xii. (1890), pp. 383-393. On the artificial fertilisation of the date-palm, see C. Ritter, Vergleichende Frkunde von Arabien, ii. 811,827 sq. 
buted not to a perception of the truth that plants have in fact their sexes, but merely to that primitive mode of thought which leads ignorant people everywhere to extend by analogy the relations of human life to every department of nature. These purely superstitious marriages of plants are common in India. For example, if a Hindoo has planted a grove of mangos, neither he nor his wife may taste of the fruit until he has formally married one of the trees, as a bridegroom, to a tree of a different sort, commonly to a tamarind-tree, which grows near it in the grove. If there is no tamarind to act as a bride, a jasmine will serve the turn. The expenses of such a marriage are often considerable, for the more Brahmans are feasted at it the greater the glory of the owner of the grove. A family has been known to sell its golden and silver trinkets, and to borrow all the money they could, in order to marry a mango-tree to a jasmine with due pomp and ceremony. ${ }^{1}$ Another plant which figures as a bride in Hindoo rites is the tulasi or Holy Basil (Ocymum Sanctum). It is a small shrub, not too big to be grown in a large flowerpot, and is often placed in rooms; indeed, there is hardly a respectable Hindoo family that does not possess one. In spite of its humble appearance, the shrub is pervaded by the essence of the great god Vishnu and his wife Lakshmi, and is itself worshipped daily as a deity. The plant is especially a woman's divinity, being regarded as an embodiment of Vishnu's wife Lakshmi, or of Rama's

- Sir W. H. Sleeman, Ramblcs and Recollections of an Indian Official (Westminster, 1893), i. 38 sq. 
wife Sita, or of Krishna's wife Rukmini. Women worship it by walking round it and praying or offering flowers and rice to it. Now this sacred plant, as the embodiment of a goddess, is annually married to the god Krishna in every Hindoo family. The ceremony takes place in November. In Western India they often bring an idol of the youthful Krishna in a gorgeous palanquin, followed by a long train of attendants, to the house of a rich man to be married to the basil ; and the festivities are celebrated with great pomp. ${ }^{1}$ Again, as the wife of Vishnu, the holy basil is married to the Salagrama, a black fossil ammonite resembling a ram's horn, which is regarded as an embodiment of Vishnu. In North-Western India this marriage of the plant to the fossil has to be performed before it is lawful to taste of the fruit of a new orchard. A man holding the fossil personates the bridegroom, and another holding the basil represents the bride. After burning a sacrificial fire, the officiating Brahman puts the usual questions to the couple about to be united. Bride and bridegroom walk six times round a small spot marked out in the centre of the orchard. ${ }^{2}$ Further, no well is considered lucky until the holy fossil has been solemnly wedded to

$1 \mathrm{~J}$. A. Dubois, Mxeurs, Instirutions et Cérímonies des peuples de l'Inde (Paris, 1825), ii. $44^{8}$ sq.; Monier Williams, Religious Life and Thought in India, pp. 333-335; W. Crooke, Popular Religion and Folk-lore of Northern Irdia (Westminster, 1896), ii. 11029.

2 Sir Henry M. Elliot, Memoirs on the History, Folk-lore, and Distribution of the Races of the North.Western Provinces of India, edited by J. Beames (London, 1869), i. $233 \mathrm{sq}$. As to the Salugrama, see G. Watt, Dictionary of the Economic Prcducts of India, vi. Part ii. (London and Calcutta, 1893), p. 384 ; G. Oppert, "Note sur les Salagramas," Compes Rendus de l'Académie des Inscriptions es Belles Lestres (Paris, 1900), pp. 472.485 . 
the holy basil, which stands for the garden that the well is intended to water. The relations assemble; the owner of the garden represents the bridegroom, while a kinsman of his wife personates the bride. Gifts are given to the Brahmans, a feast is held in the garden, and after that both the garden and the well may be used without danger. ${ }^{1}$ In these customs I would ask you to note particularly the personation of the plant by a human being. The principle of that personation has been widely applied, and, if I am right, goes far to explain the priesthood of Nemi.

The same marriage of the sacred fossil to the sacred plant is celebrated annually by the Rajah of Orchha at Ludhaura. A former Rajah used to spend a sum equal to about thirty thousand pounds, being one-fourth of his revenue, on the ceremony. On one occasion over a hundred thousand people are said to have been present at the rite, and to have been feasted at the expense of the Rajah. The procession consisted of eight elephants, twelve hundred camels, and four thousand horses, all mounted and elegantly caparisoned. The most sumptuously decorated of the elephants carried the fossil god to pay his;bridal visit to the little shrub goddess. On such an occasion all the rites of a regular marriage are performed, and afterwards the newly-wedded pair are left to repose together in the temple till the next year. $^{2}$

Here in Europe the marriage of the powers of

1 W. Crooke, op. cit. i. 49.

2 Sir W. H. Sleeman, op. cit. i. 147-149, 175. 
vegetation still survives in the ceremonies of May Day; for the King and Queen of May undoubtedly personify the reawakening energies of trees and flowers, of woods and meadows. But the consideration of these ceremonies must be reserved for the next lecture. 


\section{LECTURE VI}

Marriage of the powers of vegetation-May King and Queen in Germany and England-Marriage of the gods in ancient Babylon, Egypt, and Greece-Similar rites in ancient Sweden and Gaul-Marriage of water-gods to human brides-Stories of the Perseus and Andromeda type-The Slaying of the Dragon at Furth-St. Romain and the Dragon of Rouen.

In the last lecture we concluded our survey of what we may call the King's Progress, I mean the process by which the divine king has been gradually evolved out of the old magician or medicine-man. The general notion which we have thus gained of the evolution of the sacred kingship may now be applied to the particular instance of that institution from which we started in the first lecture. The title of the King of the Wood, bestowed on the priest of Nemi, along with his relation to the woodland goddess Diana, suggest that the two together personified the powers of vegetation in general and of the woods in particular, and that their union may, on the principles of homœopathic magic, have been regarded as a means to ensure the reproduction of that plant life on which, in the last resort, both men and animals depend for their subsistence. Customs of the same sort survive in an attenuated form in the rites which are still observed in some parts of Europe at 
the popular festivals of May Day, Whitsuntide, and Midsummer. In all these customs the essence of the rite appears to be a mimic marriage of the powers of vegetation, who after their long winter sleep manifest their renewed activity in the bursting green of the trees and the varied hues of the opening flowers. And we should fail to understand the meaning of the pageant if we regarded it merely as a dramatic representation of the great change that takes place on earth in spring and early summer. Our study of sympathetic magic, and especially of its imitative branch, has prepared us to believe that in its origin, though certainly not at the present time, the mimic marriage of the powers of vegetation, whether represented by trees or leaf-clad mummers, was a magical ceremony, a charm designed to bring about the result which it simulated; in other words, that it was intended to quicken the growth of leaves and blossoms, of grass and flowers, and of the fruits of the earth in general.

I shall not detain you with a long description of these ceremonies, but shall merely give you as samples a few instances which have come to my knowledge within the last few years. But there are some general features of the rites which it is important to apprehend because they bear directly on the worship of Nemi, if my view of that worship is correct. First, then, the human representatives of vegetation are often treated and spoken of as kings and queens ; second, the claim to these mock kingships is often determined by a contest of physical strength or agility; and thirdly, the real or 
pretended union of the human King and Queen of May would seem to have been originally an essential part of the rite, being regarded as a sympathetic charm to promote, on the principle of imitation or homœopathy, the fertility of the woods, the meadows, and the fields. Thus the license which is known to have attended these customs in the past was not an accidental excess, but on the contrary was probably regarded as an indispensable feature of the ceremonies, if they were really to produce the intended result.

With these explanations you will be able to understand the very serious meaning which these apparently gay frivolous festivals had for our forefathers : life must have been thought to depend on their performance, and death, universal death, to follow their omission. For how could men and beasts live if there should be spring no more?

To take now a few examples of these customs. A German writer thus describes the May and Whitsuntide festivals, as they used to be held in Saxony. He says that "people were not content with bringing the summer symbolically (as king or queen) into the village; they brought the fresh green itself from the woods even into the houses : that is the May or Whitsuntide trees, which are mentioned in documents from the thirteenth century onwards. The fetching in of the May-tree was a festival. The people went out into the woods to seek the May (majum quaerere), brought young trees, especially firs and birches, to the village, and set them up before the doors of the houses or of 
the cattle-stalls or in the rooms. Young fellows erected May-trees before the chambers of their sweethearts. Besides these household Mays, a great May-tree or May-pole, which had also been brought in solemn procession to the village, was set up in the middle of the village or in the market-place of the town. It had been chosen by the whole community, who watched over it most carefully. Generally the tree was stripped of its branches and leaves, nothing but the crown being left, on which were displayed, in addition to manycoloured ribbons and cloths, a variety of victuals such as sausages, cakes, and eggs. The young folk exerted themselves to obtain these prizes. In the greasy poles which are still to be seen at our fairs we have a relic of these old May-poles. Not uncommonly there was a race on foot or on horseback to the May-tree-a Whitsuntide pastime which in course of time has been divested of its goal and survives as a popular custom to this day in many parts of Germany. In the great towns of our land the custom has developed into sport, for our spring races are in their origin nothing but the old German horse-races, in which the victor received a prize (generally a red cloth) from the hand of a maiden, while the last rider was greeted with jeers and gibes by the assembled community." 1

The custom of the May-tree is observed by the Wends of Saxony, as well as by the Germans. The young men of the village choose the slimmest and tallest tree of the wood, peel it and set it up on the

1E. Mogk, in R. Wuttke's Sachsische Volkskunde ${ }^{2}$ (Dresden, 1908), Fp. 309 sq. 
village green. Its leafy top is decked with cloths and ribbons presented by the girls. Here it stands, towering high above the roofs, till Ascension Day, or in many places till Whitsuntide. When it is being taken down, the young folk dance round it, and the youth who catches and breaks off the leafy crown of the falling tree is the hero of the day. Holding the green boughs aloft he is carried shoulder-high, with music and joyous shouts, to the ale-house, where the dance is resumed. ${ }^{1}$

A regular feature in the popular celebration of Whitsuntide in Silesia used to be, and to some extent still is, the contest for the kingship. This contest took various forms, but the mark or goal was generally the May-tree or May-pole. Sometimes the youth who succeeded in climbing the smooth pole and bringing down the prize was proclaimed the Whitsuntide King and his sweetheart the Whitsuntide Bride. Afterwards, the king, carrying the May-bush, repaired with the rest of the company to the ale-house, where a dance and a feast ended the merry-making. Often the young farmers and labourers raced on horseback to the May-pole, which was adorned with flowers, ribbons, and a crown. $\mathrm{He}$ who first reached the pole was the Whitsuntide King, and the rest had to obey his orders for that day. The worst rider became the clown. At the May-tree all dismounted and hoisted the king on their shoulders. He nimbly swarmed up the pole and brought down the May-bush and the crown, which had been fastened to the top. Meantime the clown hurried to the ale-house

1 M. Rentsch, in R. Wuttke's op. cit. p. 359. 
and proceeded to bolt thirty rolls of bread and to swig four quart bottles of brandy with the utmost despatch. He was followed by the king, who bore the May-bush and crown at the head of the company. If on their arrival the clown had already disposed of the rolls and the brandy, and greeted the king with a speech and a glass of beer, his score was paid by the king, otherwise he had to settle it himself. After church time the procession wound through the village. At the head of it rode the king, decked with flowers and carrying the May-bush. Next came the clown with his clothes turned inside out, a great flaxen beard on his chin, and the Whitsuntide crown on his head. Two riders disguised as guards followed. The procession drew up before every farmyard: the two guards dismounted, shut the clown into the house, and claimed a contribution from the housewife to buy soap with which to wash the clown's beard. Custom allowed them to carry off any victuals which were not under lock and key. Last of all they came to the house in which the king's sweetheart lived. She was greeted as Whitsuntide Queen and received suitable presents. The king had the right of setting up the May-bush or Whitsuntide tree before his master's yard, where it remained as an honourable token till the same day next year. Finally the procession took its way to the tavern, where the king and queen opened the dance. ${ }^{1}$

In this last custom the part played by the clown is

1 P. Drechsler, Sirse, Brawch und Volksglaube in Schlesien, i. (Leipsic, 1903), pp. 125-128. 
not quite clear. You will observe that it is he, and not the king, who wears the crown. I conjecture that in former times a burlesque execution may have formed part of the pageant, and that the clown may have been the victim. Such executions have been not uncommon at these ceremonies. The following example will illustrate them. Sometimes in Silesia the Whitsuntide King and Queen succeeded to office as follows. A man of straw, as large as life and crowned with a red cap, was conveyed in a cart, between two men armed and disguised as guards, to a place where a mock court was waiting to try him. A great crowd followed the cart. After a formal trial the straw man was condemned to death and fastened to a stake on the execution ground. The young men with bandaged eyes tried to stab him with a spear. He who succeeded became king, and his sweetheart queen. The straw man was known as the Goliath. ${ }^{1}$ Such burlesque executions have, if my theory is right, a close bearing on the King of the Wood at Nemi, who succeeded to office by slaying his predecessor in grim earnest.

The ancient May Day ceremonies are still observed in some villages of South Warwickshire, as I learned last autumn during a visit to that charming country, where the pretty customs are fittingly framed in scenes of rural beauty that seem still to reflect the England of the olden time. Thus at the adjoining villages of Cherrington and Stourton the Queen of May is represented by a small girl dressed in white and wearing a wreath of flowers

1 P. Drechsler, $c p$. cit. i. 129. 
on her head. An older girl wheels the queen in a child's perambulator on two wheels. Four boys bear the May-pole. This is a conical framework formed of a high tripod with a central shaft. The whole structure is encased in a series of five hoops, which rise one above the other, diminishing in size upward with the tapering of the cone. The hoops, as well as the tripod and the central shaft, are all covered with whatever flowers happen to be in bloom, such as marshmarigolds, primroses, or blue-bells. To the top of the central shaft is fastened a bunch of the flower called crown-imperial, if it is in season. The lowest hoop is crossed by two bars at right angles to each other and the projecting ends of the bars serve as handles by which the four boys carry the flower-decked structure. Each of the bearers has a garland of flowers slung round his shoulder. Thus the children go from house to house singing their songs and receiving money, which goes to provide a treat for them in the afternoon. ${ }^{1}$ The so-called May-pole in this custom bears so close a resemblance to the leafy framework in which our Jack-in-the-Green and other springtide mummers walk encased that perhaps it too originally concealed a mummer, whether the King or Queen of May.

You will have noticed that in this ceremony, though the Queen of May figures, her consort the king does not. Both, however, appear at Halford, another village of South Warwickshire. Here the children

1 From information given me by Mabel Bailey, in the service of Miss A. Wyse of Halford, South Warwickshire. My informant's father is a native of Stourton, and she herself has spent much of her life there. 
go from house to house on May Day, walking two and two in procession and headed by a king and queen. Two boys carry a May-pole some six or seven feet high, which is covered with flowers and greenery. Fastened to it near the top are two cross-bars at right angles to each other. These are also decked with flowers, and from the ends of the bars hang hoops similarly adorned. At the houses the children sing May songs and receive money, which is used to provide tea for them at the schoolhouse in the afternoon. ${ }^{1}$

Ceremonies of this sort have played a great part in the popular festivals of Europe, and based as they are on a very crude conception of natural law, it is clear that they must have been handed down from a remote antiquity. We shall hardly err in assuming that they date from a time when the forefathers of the civilised nations of Europe were still barbarians, herding their cattle and cultivating patches of corn in the clearings of the vast forests, which then covered the greater part of the Continent from the Mediterranean to the Arctic Ocean. But if these old spells and enchantments for the growth of leaves and blossoms, of grass and flowers and fruit, have lingered down to our own time in the shape of pastoral plays and popular merrymakings, is it not reasonable to suppose that they survived in less attenuated forms some two thousand years ago among the civilised peoples of antiquity? Or, to put it otherwise, is it not likely that in certain festivals of the

\footnotetext{
1 From information given me by Miss A. Wyse, of Halford.
} 
ancients we may be able to detect the equivalents of our May Day, Whitsuntide, and Midsummer celebrations, with this difference, that in those days the ceremonies had not yet dwindled into mere shows and pageants, but were still religious or magical rites, in which the actors consciously supported the high parts of gods and goddesses?

I conjecture that a sacred marriage of this sort may have been annually celebrated at Nemi between the King of the Wood and his divine Queen the goddess Diana for the purpose of promoting the growth of vegetation. Direct evidence that this was so there is none, but analogy pleads in its favour, as I shall now endeavour to show.

You will observe that on my hypothesis the mortal King of the Wood was married to an immortal goddess, Diana. To us nowadays such a union appears on the face of it absurd and impossible ; but it was not so with the ancients. They sincerely believed that the marriage of a divine with a human being was not only possible but had often taken place: many persons in antiquity claimed to be direct descendants of gods. The facts are too familiar to you all to require that I should dwell upon them. I will only remark in passing, because it is germane to our subject, that in ancient Greece kings appear especially to have prided themselves on their divine origin. We have seen that the Spartan kings were believed to be descended from the supreme god Zeus; and in this respect apparently they did not differ from other kings, for in Homer a 
standing epithet of a king is "Zeus-born." But what I am here concerned to prove is that beliefs of this sort were actually embodied in religious ritual; in other words, that the marriage of the gods with human beings was often celebrated with great solemnity.

To take some instances of these ritual marriages. At Babylon the imposing sanctuary of the great god Bel rose like a pyramid above the city in a series of eight towers or stories, planted one on the top of the other. On the highest tower, reached by an ascent which wound about all the rest, there stood a spacious temple, and in the temple a great couch, magnificently draped and cushioned, with a golden table beside it. In the temple no image was to be seen, and no human being passed the night there, save a single woman, whom, according to the Chaldæan priests, the god chose from among all the women of Babylon. They said that the deity himself entered the temple by night and slept on the couch; and the woman, as the consort of the god, might not be married to a man. ${ }^{1}$ As Bel at Babylon was identified with Marduk, the chief god of the city, ${ }^{2}$ the woman who acted as his consort was doubtless one of the "wives of Marduk" who are mentioned in the recently discovered code of Hammurabi. $^{3}$

1 Herodotus, i. I8 I sq.

2 M. Jastrow, Religion of Babylonia and Assyria (Boston, 1898), pp. 117 sq.; L. W. King, Babylonian Mythology and Religion (London, 1899), pp. 18, 21 .

3 H. Winckler, Die Gesetze Hammurabi's' (Leipsic, 1903), p. 31, \$ 182 . "The votary of Marduk is the god's wife vowed to perpetual chastity, and is therefore distinct from the votaries of Ištar" (S. A. Cook, The Lawus of Moses and the Code of Hammurabi, London, 1903, p. 148). 
At Calah, which was for some time the capital of Assyria before it was displaced by Nineveh, the marriage of the god Nabu appears to have been annually celebrated on the third day of an Assyrian month, Iyyar or Airu, which corresponded to our May. The ceremonies are minutely described in a liturgical text, and from the description we gather that the officiating priestess was married to the image of the god. The image also went in procession to a grove, riding in a chariot beside the charioteer. ${ }^{1}$

At Thebes in Egypt a woman slept in the temple of Ammon as the consort of the god. ${ }^{2}$ In Egyptian texts she is often mentioned as "the divine consort," and usually she was no less a personage than the Queen of Egypt herself. For, according to the Egyptians, their monarchs were in the most literal sense the sons of the god Ammon, who at the marriage of the royal pair was supposed to assume for the time being the form of the reigning king. The divine union of the Queen of Egypt with the god is carved and painted in great detail on the walls of two of the oldest temples in Egypt, those of Luxor and Deir el Bahari ; and the inscriptions attached to the paintings leave no doubt as to the meaning of the scenes. And the birth of the divine child, the fruit of the miraculous union, is represented in equal detail. We may fairly assume,

'C. Johnston, in Fournal of the American Oriental Society, xviii. First Half (1897), Pp. 153.155; R. F. Harper, Assyrian and Babylonian Literature (New York, 1901), p. 249. For the equivalence of Iyyar or Airu with May, see Encyclopadia Biblica, s.v. "Months," iii. 3193 sg.

2 Herodotus, i. 182. 
with some eminent authorities, including Professor Maspero, that the ceremonies of the marriage and nativity of the Pharaohs, thus emblazoned on the walls of Egyptian temples, were copied from the life; in other words, that the carved and painted scenes represent a real drama, which was acted by men and women disguised as gods and goddesses whenever the King and Queen of Egypt were married, or the queen was about to give birth to an heir. "Here, as elsewhere in Egypt," says Professor Maspero, "sculptor and painter did nothing but faithfully imitate reality. Theory required that the assimilation of the kings to the gods should be complete, so that every act of the royal life was, as it were, a tracing of the corresponding act of the divine life. From the moment that the king was Ammon, he wore the costume and badges of Ammon-the tall hat with the long plumes, the cross of life, the greyhound-headed sceptre,-and thus arrayed he presented himself before the queen to celebrate his marriage. The assistants also assumed the costume and appearance of the divinities whom they incarnated: the men put on masks of jackals, hawks, and crocodiles, while the women donned masks of cows or frogs, according as they played the parts of Anubis, Khnoumou, Sovkou, Hathor, or Hiqit ; and I am disposed to believe that the doubles of the newborn child were represented by as many puppets as were required by the ceremonies. Some of the rites were complicated, and must have tired excessively the mother and child who underwent them; but they 
are nothing to those that have been observed in similar circumstances in other lands. In general, we are bound to hold that all the pictures traced on the walls of the temples, in which the person of the king is concerned, correspond to a real action in which disguised personages played the part of gods." 1

To pass now from the East to Greek lands, Apollo was said to spend the winter months at Patara in Lycia; and so long as he stayed there, his prophetess was shut up with him in the temple every night, probably because she was supposed to be his wife. ${ }^{2}$ At Ephesus there was a college of sacred men called Essenes or King Bees, who held office for a year, during which they were bound to remain celibate and to observe other rules of ceremonial purity. ${ }^{3}$ Perhaps they were deemed the husbands of Artemis, more familiarly known to us as Diana, of Ephesus, the great goddess of fertility, whose association with the bee is vouched for by the figures of bees which appear commonly both on her statues and on the coins of Ephesus. If this conjecture is right, the King Bees and their bee-

1 A. Wiedemann, Herodors zqueires Buch (Leipsic, 1890), pp. 268 sq.; G. Maspero, in Fournal des Savants, année 1899, Pp. $401-406$; A. Moret, Du caractice religieux de la royaute Pharaonique (Paris, 1902), pp. 48-73. Mr. Moret shares Prof. Maspero's view that the pictures, or painted reliefs, were copied from masquerades in which the king and other men and women figured as gods and goddesses. As to the Egyptian doctrine of the spiritual double or external soul $(K a)$, see A. Wiedemann, The Ancient Egypsian Doctrine of she Immortality of the Soul (London, 1895), pp. 10 sqg. As to the "divine consorts" of Anmon at Thebes in later ages, see Strabo, xvii. 1. 46 ; Diodorus Siculus, i. 47.

2 Herodotus, i. 182. As to the summer and winter residences of the god, see Servius, on Virgil, Aen. iv. 143 ; Horace, Odes, iii. 62 s9q.

3 Pausanias, viii. 13. 1, with my note. The Essenes or King Bees are not to be confounded with the nominal kings (Basileis) of Ephesus, who probably held office for life. See above, p. 31 . 
goddess Artemis at Ephesus would be closely parallel to the King of the Wood and his woodland-goddess Diana at Nemi, as these latter are interpreted by me. The celibacy of the priests during their year of office would be easily explicable on this hypothesis. As the consorts of the goddess they might have no human wife.

At Athens the vine-god Dionysus was annually married to the queen, but we do not know whether the part of the god in the ceremony was played by a man or an image. It would be natural to suppose that the king himself personated the divine bridegroom, as his wife the queen personated the divine bride; but of this we have no evidence. The scene of the marriage was the old official residence of the king on the north-eastern slope of the Acropolis. ${ }^{1}$ As the building bore the name of the Cattle-stall, Miss Harrison has ingeniously conjectured that Dionysus, who was often conceived by the Greek as a bull, may have been represented as a bull at his marriage. ${ }^{2}$ In that case the part of the bridegroom might be played by a man wearing a bull's head, just as in Egypt at similar rites the sacred animals were represented by men and women wearing the masks of cows, hawks,

1 Demosthenes, Contra Neaer. 73-78, pp. 1369-1371 ; Aristotle, Constitu-

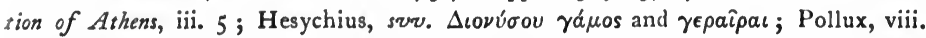
108 ; K. F. Hermann, Gottesdienstliche Alterthitmer, ${ }^{2} \S 32.15$, 58.11 sqq.; Aug. Mommsen, Feste der Stadt Athen im Altertum (Leipsic, 1898), pp. 391 sqq.; P. Foucart, Le culte de Dionysos en Attique (Paris, 1904), pp. 128 sqq.

2 Miss J. E. Harrison, Prolegomena to the Study of Greek Religion (Cambridge, 1903), p. 537. The conjecture was anticipated by Professor U. von WilamowitzMoellendorff, Aristoteles und Athen (Berlin, 1893), ii. 42. 
crocodiles, and so forth. The legend of Pasiphae and the Minotaur suggests that the custom of marrying a queen to a bull-god, that is to a man disguised as a bull, may not have been confined to Athens. ${ }^{1}$ Whether that was so or not, the ceremony of wedding the Queen of Athens to the vine-god must certainly have been intended to ensure the fertility of the vines and other fruit-trees, of which Dionysus was the god. Thus both in form and in meaning the rite would answer to the nuptials of the King and Queen of May.

If at Athens, and probably elsewhere, the vine-god was annually married to a queen in order that the vines might be loaded with clusters of green and purple grapes, there is reason to think that a marriage of a different kind, intended to make the fields wave with yellow corn, was celebrated every year not many miles off, beyond the low bare hills which bound the plain of Athens on the west. In the great mysteries solemnised at Eleusis in the month of September the union of the sky-god Zeus with the corn-goddess Demeter appears to have been represented by the dramatic union of the hierophant with the priestess of Demeter, who acted the parts of god and goddess respectively. After a period of anxious suspense, the hierophant reappeared and in a blaze of light silently exhibited to the assembled worshippers a reaped ear

1 Mr. A. B. Cook was the first, I believe, to suggest that the legend of Pasiphae and the Minotaur contains a reminiscence of a marriage ceremony in which the King and Queen of Cnossus figured in the disguise of a bull and a cow respectively. See his article "Zeus, Jupiter, and the Oak," Classical Revienu, xvii. (1903), pp. $410,412$. 
of corn, the fruit of the divine marriage. Then in a loud voice he proclaimed that the queen had been delivered of a child. The corn-mother, in fact, had given birth to the corn. This revelation of the reaped ear seems to have been the crowning act of the mysteries. ' Thus through the glamour shed around these rites by the poetry and philosophy of later ages there still looms, like a distant landscape through a sunlight haze, a simple rustic festival designed to cover the wide Eleusinian plain with a plentiful harvest by wedding the goddess of the corn to the sky-god, who fertilised the bare earth with genial showers.

But Zeus was not always the sky-god, nor was he always married to the corn-goddess. If in antiquity a traveller, quitting Eleusis and passing through miles of olive-groves and cornfields, had climbed the pineclad mountains of Cithæron and descended through the forest on their northern slope to Platæa, he might have chanced to find the people of that little Bœotian town celebrating a different marriage of the great god to a different goddess. On a certain day they went into a primæval oak-wood and set meat on the ground at the foot of the giants of the forest. When a raven was observed to swoop on the meat and carry it off to

1 Tertullian, Ad Nationes, ii. 7 ; Asterius Amasenus, in Migne's Patrologia Graeca, x1. col. 324 ; Psellus, Quaenam sunt Graecorum opiniones de daemonibus, p. 39, ed. J. F. Boissonade (compare Arnobius, Adversus Nationes, v. 20-23); Schol. on Plato, Gurgias, p. 497 c ; Hippolytus, Refutatio omnium haeresium, v. 8, pp. 162, I64, ed. Duncker and Schneidewin. In combining and interpreting this fragmentary evidence I have followed Mr. P. Foucart (Recherches sur l'origine et la nature des mystères d'Éleusis, Paris, 1895, pp. 48 sq.; Les grands mystères d'Éleusis, Paris, 1900, p. 69) and Miss J. E. Harrison (Prolegomena to the Study of Greek Religion, pp. 549 sqq.). 
an oak, the people followed it and cut down the tree. With the wood of the tree they made an image, dressed it as a bride, and placed it on a bullock-cart with a bridesmaid beside it. Then it seems to have been drawn to the river and back to the town attended by a piping and dancing crowd. After the festival, which was held every few years, the image was put away and kept with others of the same sort till another festival called the Great Drdala came round, which was celebrated by all the people of Bœotia once in every sixty years. On that occasion all the images that had accumulated at the lesser festivals were dragged on wains to the top of Mount Cithæron and there burned in a huge bonfire, of which the blaze could be seen for miles over the country. The legend told to account for these festivals seems to show that the ceremony represented the marriage of Zeus, the oak god, to the goddess or nymph of the oak, who was personated by the oaken image dressed as a bride. ${ }^{1}$ Whether the part of Zeus at the marriage was acted by a man or an image is not clear.

The sacred marriage of Zeus and Hera had, as was natural, its counterpart in heathen times among the northern kinsfolk of the Greeks. In Sweden every year a life-size image of Frey, the god of fertility, both animal and vegetable, was drawn about the country in a waggon attended by a beautiful girl who was called the god's wife. She acted also as his priestess in his great temple at Upsala. Wherever the waggon came

1 Pausanias, ix. 3 ; Plutarch, quoted by Eusebius, Pracpar. Evang. iii. 1 sq. 
with the image of the god and his blooming young bride, the people crowded to meet them and offer sacrifices for a fruitful year. ${ }^{1}$

Similar ceremonies appear to have been observed by the peasantry of Gaul in antiquity; for Gregory of Tours, writing in the sixth century of our era, says that at Autun the people used to carry about an image of a goddess in a waggon drawn by oxen. The intention of the ceremony was to ensure the safety of the crops and vines, and the rustics danced and sang in front of the image. $^{2}$ The old historian identifies the goddess with Cybele, the great Mother Goddess of Phrygia, and the comparison, if not the identification, is just; for the rites of Cybele conformed closely to the type of the sacred marriage here discussed. On the day of the spring equinox (the $22 \mathrm{nd}$ of March) a pine-tree was cut and brought into the sanctuary of the goddess, where it was worshipped as a divinity. The effigy of a young man, doubtless representing Attis, the consort of Cybele, was attached to the tree, and the festival ended with the drawing of the image of the goddess in a bullock-cart to a brook, where it was bathed, ${ }^{3}$ perhaps as a bride after her marriage. And the relation of the

1 J. Grimm, Deutsche Mythologie, ${ }^{4}$ i. 176 ; P. Hermann, Nordische Mythologie (Leipsic, 1903), pp. 198 sqq., 217, 520, 529 ; E. H. Meyer, Mythologie der Germanen (Strasburg, 1903), pp. $366 \mathrm{sq}$. The procession of Frey and his wife in the waggon is probably the same with the procession of Nerthus in a waggon which Tacitus describes (Germania, 40). Nerthus seems to be no other than Freya, the wife of Frey. See the commentators on Tacitus, l.c., and especially K. Müllenhoff, Deutsche Altertumskunde, iv. 468 sq.

2 Gregory of Tours, De gloria confessorum, 77 (Migne's Patrologia Latina, 1xxi. col. 884). Compare Sulpicius Severus, Vita S. Martini, 12.

${ }^{3}$ See The Golden Bough, ${ }^{2}$ ii. ${ }_{3}$ 1 sq.; H. Hepding, Attis, seine Mythen und sein Kult Giessen, 1903), pp. 147 sqq. 
Phrygian to the northern worship of a great goddess of fertility was probably one not merely of similarity but of actual kinship, based on common descent; for the Phrygians were unquestionably an Aryan tribe who had crossed from Europe into Asia. At all events we may make sure that the goddess whom the peasants of Gaul carted about to bless their crops and their vines was of native origin; and we can hardly hesitate to see in her and in Frey's wife the old French and Swedish equivalents of the May Queen.

It would be easy to show by a list of examples that the custom of marrying a god or spirit to a woman has been widespread in other parts of the world. Here I shall content myself with observing that the deity who is thus provided with a human bride is often a waterspirit. Thus, to take a few instances, the god of the great Victoria Nyanza Lake in Central Africa was propitiated by the Baganda every time they undertook a long voyage, and they furnished him with girls to serve as his wives. The custom lasted until King Mwanga was converted to Christianity. ${ }^{1}$ Again in one of the states of Upper Burma there is a certain lake, the spirit of which is regarded as very powerful and is propitiated with offerings every year. A remarkable feature of the worship of this spirit of the lake is the dedication to him of four maidens in marriage. The custom was last observed in 1893: the present chief has omitted it. Soon after being wedded to the water-god, the girls are allowed to return home. If nothing happens, the

I Sir Harry Johnston, The Uganda Protecrorate (London, 1902), ii. 677. 
spirit of the lake cares little for them; but if one of them dies, it is a sign that he loves her and has taken her to himself. ${ }^{1}$ Sometimes, apparently, it has not been left to the discretion of the divine bridegroom to take or leave his human bride: she has been made over to him once for all in death. When the Arabs conquered Egypt they learned that at the rise of the Nile the Egyptians were wont to deck a young girl in gay apparel and throw her into the river as a sacrifice, in order to obtain a plentiful inundation. The Arab general abolished the barbarous custom. ${ }^{2}$ The princes of Koepang, a state in the East Indian island of Timor, deemed themselves descended from crocodiles, and on the coronation of a new prince a solemn sacrifice was made to the crocodiles in presence of the people. The offerings consisted of a pig with red bristles and a young girl, prettily dressed, perfumed, and decked with flowers. She was taken down to the bank of the river and set on a sacred stone in a cave. Soon one of the reptiles appeared and dragged the girl down into the water. The people thought that he married her. ${ }^{3}$ On festal occasions in the same state a new-born girl was sometimes dedicated to a crocodile, and then, with certain ceremonies of consecration, was

1 J. G. Scott and P. J. Hardiman, Gazetteer of Upper Burma and the Shan States, Part ii. vol. i. (Rangoon, 1901), p. 439.

${ }^{2}$ E. W. Lane, Manners and Customs of the Modern Egvptians (Paisley and London, 1895), chap. xxvi. p. 500. The authority for the statement is the Arab historian Makrizi.

3 G. A. Wilken, "Het animisme bij de volken van den Indischen Archipel," De Indische Gids, June 1884, p. 994 (referring to Veth, Het eiland Timor, p. 21); A. Bastian, Indonesien, ii. (Berlin, 1885), p. 8. 
brought up to be married to a priest. ${ }^{1}$ In this last custom the priest perhaps represents a crocodile, and the practice of marrying a girl to him may well be a humane mitigation of the older custom of exposing her to the monster. It is said that once when the inhabitants of another East Indian island were threatened with destruction by a swarm of crocodiles, they ascribed the misfortune to a passion which the prince of the crocodiles had conceived for a certain girl. Accordingly they compelled the damsel's father to dress her in bridal array and deliver her over to the clutches of her crocodile lover. ${ }^{2}$

A usage of the same sort is said to have prevailed in the Maldive Islands before their conversion to Islam. The famous Arab traveller Ibn Batutah has described the custom and the manner in which it came to an end. He was assured by several trustworthy natives, whose names he gives, that when the people of the islands were idolaters there appeared to them every month an evil spirit among the jinn, who came from across the sea in the likeness of a ship full of burning lamps. The wont of the inhabitants, as soon as they perceived him, was to take a young maiden, and having adorned her, to lead her to a heathen temple that stood on the shore, with a window looking out to sea. There they left the damsel for the night, and when they came back in the morning they found her dead. Every month they drew lots, and he upon whom the lot fell gave up

1 A. Bastian, op. cir. p. 11.

2 A. Bastian, Indonesien, i. (Berlin, 1884), p. 134. 
his daughter to the spirit of the sea. This went on till a Berber, who knew the Coran by heart, landed in the islands and rescued the doomed maiden, like another Andromeda, from the demon, whom he put to flight by reciting passages of the holy book till break of day. After that the joyful people, freed from this tribute to the cruel demon, embraced Islam. When Ibn Batutah himself arrived in the islands, he knew nothing of these things. One night as he was going about his business, he heard of a sudden people saying in a loud voice, "There is no God but God," and "God is great." He saw children carrying copies of the Coran on their heads, and women beating on basins and vessels of copper. He was astonished at what they did, and he said, "What has happened ?" They answered, "Doest thou not behold the sea ?" He looked towards the sea and beheld in the darkness as it were a great ship full of burning lamps and cressets. They said to him, "That is the demon. It is his wont to show himself once a month; but after we have done that which thou hast seen, he returns to his place and does us no manner of harm." 1

It occurred to me that this myth of the demon lover may have been based on some phenomenon of light which is periodically visible at night in the Maldive Islands. Accordingly I consulted our most eminent authority on these islands, Mr. J. Stanley Gardiner of Caius College. His answer confirmed my conjecture.

1 Voyages d'Ibn Batoutah, texte Arabe, accomfagné d'une traduction, par C. Defrémery et B. R. Sanguinetti (Paris, $1853-185^{8}$ ), iv. $126-130$. 
He wrote to me: "A peculiar phosphorescence, like the glow of a lamp hidden by a roughened glass shade, is occasionally visible on lagoon shoals in the Maldives. I imagine it to have been due to some single animal with a greater phosphorescence than any at present known to us. A periodical appearance at some phase of the moon due to reproduction is not improbable, and has parallels. The myth still exists in the Maldives, but in a rather different form." $\mathrm{He}$ adds that "a number of these animals might of course appear on some shoal near Male," the principal island of the group. To the eyes of the ignorant and superstitious such a mysterious glow, suddenly lighting up the sea in the dusk of the evening, might well appear a phantom ship, hung with burning lamps, bearing down on the devoted islands, while the roar of the surf on the barrier reef might sound in their ears like the voice of the demon calling for his prey.

Ibn Batutah's narrative of the demon lover and his mortal bride closely resembles a well-known type of folk-tale, of which versions have been found from Japan and Annam in the East to Senegambia, Scandinavia, and Scotland in the West. The story varies in details from people to people, but as commonly told it runs thus. A certain country is infested by a manyheaded serpent, dragon, or other monster, which would destroy the whole people if a human victim, generally a virgin, were not delivered up to him periodically. Many victims have perished, and at last it has fallen to the lot of the king's own daughter to be sacrificed. She 
is exposed to the monster, but the hero of the tale, generally a young man of humble birth, interposes on her behalf, slays the beast, and receives the hand of the princess and a share of the kingdom as his reward. In many of the tales the monster, who is sometimes described as a serpent, inhabits the water of a sea, a lake, or a fountain. In other versions he is a serpent or dragon who takes possession of the springs of water, and only allows the water to flow or the people to make use of it on condition of receiving a human victim. ${ }^{1}$

It would probably be a mistake to dismiss all these tales as pure inventions of the story-teller. Rather we may suppose that they reflect a real custom of sacrificing girls or women to be the wives of water-spirits, who are very often conceived as great serpents or dragons. ${ }^{2}$ Among civilised peoples these customs survive for the most part only in popular tales, of which the legend of Perseus and Andromeda, with its mediæval counterpart of St. George and the Dragon, is the most familiar example. But occasionally they appear to have left

1 For a list of these tales, with references to the authorities, see my note on Pausanias, ix. 26. 7. To the examples there referred to add J. V. Zingerle, Kinderund Hausmärchen aus Tirol, Nos. 8, 21, 35, pp. 35 sqq., 100 sqq., 178 sqq.; G. F. Abbott, Macedonian Folk-lore (Cambridge, 1903), pp. 270 sqq. This type of tale has been elaborately investigated by Mr. E. S. Hartland (The Legend of Perseus, London, 1894-1896); but while he illustrates the details of the story with a profusion of learning, he has not, so far as I have observed, dealt with the actual custom of marrying women to supernatural beings, especially to water-spirits. More examples of it will be given in the third edition of The Golden Bough.

2 To the evidence collected in my note on Pausanias, ix. 10. 5, add H. TernauxCompans, Essai sur l'ancien Cundinamarca, pp. 6 sq.; R. Salvado, Mémoires historiques sur l'Australie (Paris, 1854), p. 262; H. Coudreau, Chez nos Indiens (Paris, 1895), pp. 303 sq.; C. Lumholtz, Unknown Mexico, i. 402 sq., ii. 57 ; Spencer and Gillen, Northern Tribes of Central Australia, pp. 226 sqq. 
traces of themselves in ceremonies and pageants. Thus at Furth in Bavaria a drama called the Slaying of the Dragon used to be acted every year about Midsummer, on the Sunday after Corpus Christi Day. Crowds of spectators flocked from the neighbourhood to witness it. The scene of the performance was the public square. On a platform stood or sat a princess wearing a golden crown on her head, and as many silver ornaments on her body as could be borrowed for the purpose. Opposite her was stationed the dragon, a dreadful monster of painted canvas stretched on a wooden skeleton and moved by two men inside. A knight in armour rode forth and asked the princess why she looked so sad. She told him that the dragon was coming to eat her up. He bade her be of good cheer, and attacked the dragon, thrusting his spear into its maw and stabbing a bladder of bullock's blood which was there concealed. The gush of blood which followed was an indispensable part of the show; the people eagerly mopped it up, along with the blood-soaked earth, in white cloths, which they afterwards laid on the flax-fields, in order that the flax might thrive and grow tall. For the "dragon's blood" was thought to be a sure protection against witchcraft. Having despatched the dragon, the knight announced her deliverance to the princess. She in return tied a wreath round his arm and told him that her noble father and mother would soon come to give them half the kingdom. ${ }^{3}$ In

\footnotetext{
ii. 550 .

1F. Panzer, Beitrag eur deusschen Myshologic (Munich, 1848-1855), i. 107-110,
} 
this custom the use of the dragon's blood to make the flax grow proves that the ceremony of the Slaying of the Dragon was not a mere popular spectacle, but a magical rite designed to fertilise the fields. As such it probably descended from a very remote antiquity, and may well have been invested with a character of solemnity, if not of tragedy, long before it degenerated into a farce.

More famous was the dragon from which, according to legend, St. Romain delivered Rouen, and far more impressive was the ceremony with which, down to the French Revolution, the city commemorated its deliverance. The stately and beautiful edifices of the Middle Ages, which still adorn Rouen, formed a fitting background for a pageant which carried the mind back to the days when Henry II. of England and Richard Cœur de Lion, Dukes of Normandy, still had their palace in this ancient capital of their ancestral domains. Legend ran that about the year 520 A.D. a forest or marsh near Rouen was infested by a monstrous beast in the shape of a serpent or dragon, which every day wrought great harm to the city and neighbourhood, devouring man and beast, causing boats and mariners on the river Seine to perish, and inflicting other woes innumerable on the commonwealth. At last the archbishop, St. Romain, resolved to beard the monster in his den. He could get none to accompany him but a prisoner condemned to death for murder. On their approach the dragon appeared as though he would swallow them up; but the archbishop, relying on the divine help, made the 
sign of the cross, and at once the monster became so gentle that he suffered the saint to bind him with his stole and the murderer to lead him like a lamb to the slaughter. Thus they went in procession to a public place in Rouen, where the dragon was peaceably burnt in the presence of the people and its ashes cast into the river. The murderer was pardoned for his services; and the fame of the deed having gone abroad, St. Romain, or his successor St. Ouen, whose memory is enshrined in a church of dream-like beauty at Rouen, obtained from King Dagobert in perpetuity a privilege for the archbishop, dean, and canons of the cathedral, to wit, that every year on Ascension Day, the anniversary of the miracle, they should pardon and release from prison a malefactor, whomsoever they chose, and whatever the crime of which he had been guilty. This privilege, unique in France, is known from documentary evidence to have been exercised from nearly the beginning of the thirteenth century down to I790, when the chapter intervened to stay the sword of justice for the last time. Next year the face of things had changed: there was neither archbishop nor chapter in Rouen. A register of the prisoners who were pardoned, together with an account of their crimes, was kept, and still exists. Most of the crimes appear to have been murder or homicide.

The proceedings on the great day of pardon varied somewhat in different ages. The following account is based in great part on a description written in the reign of Henry III. and published at Rouen in 1587 . On 
the Monday of Rogations two canons examined the prisoners and took their confessions, going from prison to prison till Ascension Day. On that day, about seven o'clock in the morning, all the canons assembled in the chapter-house, and invoked the grace of the Holy Spirit by the hymn Veni creator Spiritus and other prayers. Also they made oath to reveal none of the depositions of the criminals, but to hold them sacred under the seal of confession. The depositions having been taken and the commissioners heard, the chapter, after due deliberaiton, named him or her among the prisoners who was to receive the benefit of the privilege. A card bearing the prisoner's name and sealed with the seal of the chapter was then sent to the members of parliament, who were sitting in full assembly, clad in their red robes, in the great hall of the palace to receive the nomination of the prisoner, and to give it legal effect. The criminal was then released and pardoned. Immediately the minster bells began to ring, the doors of the cathedral were flung open, the organ pealed, hymns were sung, candles lit, and every solemnity observed in token of joy and gladness. Then the archbishop and all the clergy of the cathedral went in procession to the great square known as the Old Tower near the river, carrying the shrines and reliquaries of the minster, and accompanied by the joyous music of hautboys and clarions. In the square there stood, and still stands, a platform of stone raised high above the ground and approached by flights of steps. Thither they brought the shrine (fierte) of St. Romain, and 
thither too was led the pardoned prisoner. $\mathrm{He}$ ascended the platform, and after confessing his sins and receiving absolution, he thrice lifted the shrine of St. Romain, while the innumerable multitude assembled in the square cried aloud, each time the shrine was lifted, "Noel! Noel! Noel!" which was understood to mean "God be with us!" That done, the procession reformed and returned to the cathedral. At the head walked a beadle clad in violet, who bore on a pole the wicker effigy of the winged dragon of Notre Dame, holding a large fish in its mouth. The whispers and cries excited by the appearance of the monster were drowned in the loud fanfares of cornets, clarions, and trumpets. Behind the musicians, who wore the liveries of the Master of the Brotherhood of Notre Dame with his arms emblazoned on an ensign of taffeta, came the carved silver-gilt shrine of Notre Dame. After it followed the clergy of the cathedral to the number of two hundred, clad in robes of violet or crimson silk, bearing banners, crosses, and shrines, and chanting the hymn De resurrectione Domini. Then came the archbishop, giving his blessing to the great multitude who thronged the streets. The prisoner himself walked behind, bareheaded, crowned with flowers, carrying one end of the litter which supported the shrine of St. Romain : the fetters he had worn hung from the litter; and with him paced, with lighted torches in their hands, the men or women who, for the last seven years, had in like manner received their pardon. Another beadle, in a violet livery, marched behind bearing aloft on a pole 
the wicker effigy of the dragon destroyed by St. Romain. The clergy of the thirty-two parishes of Rouen also took part in the procession, which moved from the Old Tower to the cathedral amid the acclamations of the crowd, while from every church tower in the city the bells rang out a joyous peal, the great bell Georges d'Amboise thundering above them all. After mass had been performed in the cathedral, the prisoner was taken to the house of the Master of the Brotherhood of St. Romain, where he was magnificently feasted, lodged, and served, however humble his rank. Next morning he again presented himself to the chapter, where, kneeling in the presence of a great assembly, he was severely reproved for his sins, and admonished to give thanks to God, to St. Romain, and to the canons for the pardon he had received in virtue of the privilege. ${ }^{1}$

What was the origin and meaning of this remarkable privilege of the fierte, as the shrine of St. Romain was called? Its history has been carefully investigated

1 F. N. Taillepied, Recueil des Antiquiter et Singularite: de la ville de Rouen (Rouen, 1587), pp. 93-105; A. Floquet, Histoire du privilége de Saint Romain (2 vols. 8vo, Rouen, 1833). For briefer notices of the custom and legend, see A. Bosquet, La Normandie Romanesque et Merveilleuse (Paris and Rouen, 1845), Pp. 405-409; A. de Nore, Coutumes, Mythes et Traditions des Provinces de France (Paris and Lyons, 1846), pp. 245-250. The gilt fierte or portable shrine of St. Romain is preserved in the Chapter Library of the Cathedral at Rouen, where I saw it in May 1902. It is in the form of a chapel, on the roof of which the saint stands erect, trampling on the winged dragon, while the condemned prisoner kneels in front of him. This, however, is not the original shrine, which was so decayed that in 1776 the chapter decided to replace it by another. See Floquet, op. cit. ii. 338-346. The custom of carrying the dragons in procession was stopped in 1753 because of its tendency to impair the solemnity of the ceremony (Floquet, ii. 301 ). Even more famous tham the dragon of Rouen was the dragon of Tarascon, an effigy of which used to be carried in procession on Whitsunday. See A. de Nore, op. cit. pp. 47 sqq. Neither of these monsters is mentioned by Mr. P. Sebillot in his account of French dragons (Le folk-lore de France, i. (Paris, 1904), pp. 468-4;0). 
by Mons. A. Floquet, Chief Registrar of the Royal Court of Rouen, with the aid of all the documentary evidence, including the archives both at Rouen and Paris. He supposes the ceremony to have been in its origin a scenic representation of the triumph of Christ over $\sin$ and death, the deliverance of the condemned prisoner symbolising the deliverance of man from the yoke of corruption, and bringing home to the people in a visible form the great mystery which the festival of the Ascension was instituted to commemorate. Such dramatic expositions of Christian doctrine, he points out, were common in the Middle Ages.

Plausible as is this solution of the problem, it can scarcely be regarded as satisfactory. Had this been the real origin of the privilege we should expect to find the Ascension of Christ either plainly enacted, or at least distinctly alluded to in the ceremony; but apart from the singing of the hymn De resurrectione Domini this seems not to have been the case. Moreover, the part played by the dragon in the legend and in the spectacle seems too important to allow us to explain it away, with M. Floquet, as a mere symbol of the suppresssion of paganism by St. Romain. The tale of the conquest of the dragon is older than Christianity and cannot be explained by it. Judging from the analogy of similar tales elsewhere, we may conjecture that in the Rouen version the condemned criminal represents a victim annually sacrificed to a waterspirit or other fabulous being, while the Christian saint has displaced a pagan hero, who was said to 
have delivered the victim from death and put an end to the sacrifice by slaying the monster. Thus it seems possible that the custom of annually pardoning a condemned malefactor may have superseded an older practice of treating him as a public scapegoat, who died to save the rest of the people. Such customs have been observed in many lands. It is not incredible that at Rouen a usage of this sort should have survived in a modified shape from pagan times down to the twelfth century, and that the Church should at last have intervened to save the wretch and turn a relic of heathendom to the glory of God and St. Romain.

One more point and I have done. The sacrifice of women to water-spirits appears to have been commonly intended to provide these mythical beings with wives. Wherever that has been so, the water-spirit is obviously supposed to be male. But men have also been sacrificed to water-spirits $;^{1}$ and where that has been the practice, we may conjecture, though it certainly does not come out clearly, that the spirits are conceived as female and the human victims as their husbands. Whether the dragon of Rouen was considered as male or female, we cannot say, since the condemned prisoners, who on my hypothesis represented the victims formerly offered to him or her, might be either men or women.

So much for the sacred marriage in general. In the

1 W. F. W. Owen, Narrative of Voyages to explore the shores of Africa, Arabia, and Madagascar (London, 1833), ii. 354 sq.; Annales de la Propagation de la Foi, xxxiii. (1861), p. 152 ; id. 1x. (1888), p. 253 ; E. Aymonier, "Les Tchames et leurs religions," Revise de l'Histoire des Religions, xxiv. (1891), p. 213. 
next lecture I shall apply the results of our inquiry to the legendary history of the Latin kings, especially the kings of Rome, to a consideration of whose office the remainder of the lectures will be mainly devoted. 


\section{LECTURE VII}

The Sacred Marriage-Numa and Egeria_Kings of Rome and Alba personified Jupiter, the god of the oak and the thunderSacred marriage of Jupiter and Juno perhaps enacted by the King and Queen of Rome-Roman kings regarded as sons of the fire god by his wives the Vestal Virgins-Sacred fires and Vestal Virgins in Ireland and Peru.

IN the last lecture I adduced some examples of what may be called the sacred marriage or the marriage of the gods. The custom consists in solemnly marrying the gods to each other or to human beings who act as consorts of the deities. Amongst the divine powers whose wedding is thus publicly celebrated, the deities of vegetation and of water hold a conspicuous place. Such rites appear to aim at ensuring the fertility of the earth, upon which the life of animals and of men ultimately depends. Our survey of them may perhaps be allowed to strengthen my conjecture that a sacred marriage like that of our King and Queen of May was annually solemnised at $\mathrm{Nemi}$, the wedded pair being the mortal King and the immortal Queen of the Wood, Diana. In this connection it is to be remembered that the worship of the sacred grove at Nemi centred round the powers 
of water as well as of vegetation. The sanctuary of the goddess stood on the shore of a secluded lake which was known as Diana's mirror ; and further, one of the mythical personages of the grove was Egeria, the nymph of a sacred spring. Here I would remind you that, as I mentioned in my first lecture, the nymph Egeria was said to be the wife of the old Roman king Numa. Have we not in this legend the reminiscence of a custom of marrying the King of Rome to a goddess, like the custom of marrying the Queen of Athens to a god? Observe that Numa was the very type of a priestly king; most of the religious institutions of Rome were referred to him as their founder. Such a king is precisely the sort of personage most likely to contract a sacred union with a goddess, whether the goddess is represented in the rite by an image or by a woman, who would most naturally be the king's own wife, the queen. You will remember that the Queen of Egypt as well as the Queen of Athens played the part of the divine consort in the sacred marriage. Further, it should be borne in mind that according to one tradition the union of Numa with Egeria actually took place in the hallowed wood at Nemi. This tradition may well contain an echo of a similar marriage between the King of the Wood and Diana in the same holy grove. At least the coincidence is curious enough to justify us in scrutinising more closely both Numa and Egeria, in order to see whether we cannot detect an affinity, on the one hand, between Egeria and Diana, and, on 
the other hand, between Numa and the King of the Wood. Let us begin with Egeria.

We saw in the first lecture that Egeria, like Diana, was regarded as a divinity who aided women in childbirth; and further, she was, like Diana, associated with water, being the nymph of a spring, while Diana was the goddess of the lake. Moreover, like Diana, she was also a tree-spirit; for Plutarch tells us definitely that she was a dryad or nymph of an oak; ${ }^{1}$ and this statement is strongly confirmed by the etymology of her name, if $\mathrm{Mr}$. A. B. Cook is right in deriving it from the same root aeg which appears in the Latin

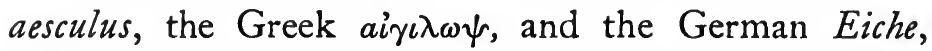
all meaning "an oak." 2 So many coincidences between Egeria and Diana can hardly be accidental. We may assume with a fair degree of probability that Egeria and Diana, though they differ in name, are identical in substance. Accordingly, we may restate the Roman legend in other words by saying that the King of Rome was married to the oak-goddess Diana either in the sacred grove at Nemi or, according to others, in a grove outside the walls of Rome.

But we have still to ask whether in this sacred marriage the Roman king personated a god? and if so, which god? That he should have posed as a deity will not seem improbable when we remember how many monarchs have claimed to be divine. The old Greek kings appear to have set up for being not merely

1 Plutarch, De fortuna Romanorum, 9.

2 A. B. Cook, "Zeus, Jupiter, and the Oak," Classical Reviezv, xviii. (1904), p. 366. The name is spelt Aegeria by Valerius Maximus (i. 2. 1). 
descendants of Zeus but actual embodiments on earth of the great god; for the learned Tzetzes, a mine of antiquarian lore, tells us repeatedly that of old every king bore the title of Zeus $;^{1}$ and the legend of Salmoneus, King of Elis, who posed as Zeus and in that character made mock thunder and lightning, ${ }^{2}$ probably reflects the regular practice of early Greek kings. But if Greek kings claimed to be Zeus, we should expect to find the Latin kings claiming to be Jupiter, the Italian counterpart of Zeus. That they actually did so is indicated by a variety of evidence, to which I would now invite your attention.

In the first place, then, they seem to have dressed themselves as Jupiter and to have assumed his attributes. For down to imperial times victorious generals celebrating a triumph, and magistrates presiding at the games in the Circus, wore the costume of Jupiter, which was borrowed for the occasion from his great temple on the Capitol ; and it has been held with a high degree of probability both by ancients and moderns that in doing so they merely copied the traditionary attire and insignia of the Roman kings. ${ }^{3}$ They rode a chariot drawn by

1 J. Tzetzes, Antchomerica, 102 sq.; id., Chiliades, ix. 452. Mr. A. B. Cook was the first, so far as I know, to call attention to this important statement of Tzetzes. See his articles in The Classical Review, xvii. (1903), p. 409, and Folk-lcre, xv. (1904), pp. 303 sq.

2 Apollodorus, i. 9. 7 ; Virgil, Aen. vi. $5^{85}$ sqq.; Servius, on Virgil, l.c.

3 Dionysius Halicarnasensis, Antiquir. Rom. iii. 6r sq., iv. 74 , v. 35 ; B. G. Niebuhr, Hissory of Rome, ii. 36 ; Th. Mommsen, Hissory of Rome, New Edition (London, 1894), i. 83 ; A. J. H. Greenidge, Roman Public Life (London, 1901), pp. $44 \mathrm{sq}$. But Mommsen, while he holds that the costume of a Roman god and of a Roman king was the same, denies that the king personated the god. A truer historical insight is displayed by that great scholar K. O. Muller in his treatment of the subject (Die Errusker, Stuttgart, 1877 , i. $34^{8}$ sq.). See further Th. Mommsen, 
four laurel-crowned horses through the city, where every one else went on foot: they wore purple robes embroidered or spangled with gold : in the right hand they bore a branch of laurel, and in the left hand an ivory sceptre topped with an eagle : a wreath of laurel crowned their brows: their face was reddened with vermilion; and over their heads a slave held a heavy crown of massy gold fashioned in the likeness of oak leaves. ${ }^{1}$ In this attire the assimilation of the man to the god comes out above all in the eagle-topped sceptre, the oaken crown, and the reddened face. For the eagle was the bird of Jove, the oak was his sacred tree, and the face of his image on the Capitol was in like manner regularly dyed red on festivals ; indeed, so important was it deemed to keep the divine features properly rouged, that one of the first duties of the censors was to contract for having this done. ${ }^{2}$ The Greeks sometimes painted red the face or the whole

Römisches Staatsrecht, ${ }^{3}$ i. 372 sq., ii. 5 sq.; J. Marquardt, Römische Staatsverwaltung, ii. 566 sq., iii. ${ }^{2} 507$ sq.; id., Privatleben der Römer, ${ }^{2} 542$ sq.; K. O. Müller, op. cit. i. 344-350, ii. 198-200 ; Aust, s.v. "Jupiter," in W. H. Roscher's Lexikon der griech. und röm. Mythologie, ii. 633, 725-728. Among the passages of ancient authors on the subject are Appian, Pun. 66 ; Zonaras, Annal. vii. 8 and 21 ; Juvenal, x. 36-43; Servius, on Virgil, Ecl. vi. 22, x. 27; Ael. Lampridius, Alexander Severus, 40. 8 ; Jul. Capitolinus, Gordiani Tres, 4.4 ; Aulus Gellius, v. 6. 5-7. The fullest descriptions of a Roman triumph are those of Appian and Zonaras.

1 Tertullian, De corona militis, 13 ; compare Pliny, Nat. Hist. xxxiii. I1 ; Zonaras, Annal. vii. 21 ; Juvenal, x. $3^{8}$ sqq. Mommsen says that the triumphal golden crown was made in the shape of laurel leaves (Römischer Staatsrecht, $\mathrm{i}^{3}{ }^{32}$ ) ; but none of the ancient authors cited by him appears to affirm this, with the doubtful exception of Aulus Gellius (v. 6. 5-7), who may have confused the wreath of real laurel which the general wore on his head (Pliny, Nat. Hist. xxxiii. 127, 130, 137) with the golden crown which was held over him by a slave. The two crowns are clearly distinguished by Zonaras (l.c.), though he does not describe the shape of the golden crown. Mommsen himself mentions "a chaplet of oaken leaves in gold" as part of the insignia of the Roman kings (Roman History, London, 1894, i. 83).

2 Pliny, Nat. Hist. xxxiii. I I sq.; Servius, on Virgil, Ecl. vi. 22, x. 27. 
body of the wine-god Dionysus. ${ }^{1}$ These customs may have been a substitute for an older practice of feeding the god by smearing the face, and especially the lips, of his idol with the blood of a sacrificial victim. As the triumphal procession always ended in the temple of Jupiter on the Capitol, it was peculiarly appropriate that the head of the victor should be graced by a crown of oak leaves; for not only was every oak consecrated to Jupiter, ${ }^{2}$ but the Capitoline temple of the god was said to have been built by Romulus beside a holy oak, venerated by shepherds, to which the king attached the spoils won by him from the enemy's general in battle. ${ }^{3}$ We are expressly told that the oak crown was sacred to Capitoline Jupiter $;^{4}$ a passage of Ovid proves that it was regarded as the god's special emblem. Writing in exile on the shores of the Black Sea, the poet sends the book which he has just composed to Rome to be published there : he personifies the volume and imagines it passing along the Sacred Way and up to the door of the emperor's palace on the Palatine hill. Above the portal hung shining arms and a crown of oak leaves. At the sight the poet starts: "Is this, quoth I, the house of Jove? For sure to my prophetic soul the oaken crown was reason good to think it so." ${ }^{5}$ The senate had granted Augustus the right to have the wreath of oak always suspended over his door $;^{6}$ and in

1 Pausanias, ii. 2. 6 (with my note), vii. 26. 11 , viii. 39. 6.

2 Pliny, Nas. Hiss. xii. 3 ; Phaedrus, iii. 17. 1 sqg.; Servius, on Virgil, Georg. iii. 332, and Ecl. i. 17.

Livy, i. 10. 4 sgg.

Ovid, Tristia, iii. 31 s9g.

4 Plutarch, Quacs, Rom. 92.

- Dio Cassius, liii. 19. 
another passage Ovid counts this among the more than mortal honours bestowed on the emperor. ${ }^{1}$ On the Capitol at Cirta there stood a silver image of Jupiter wearing a silver crown of oak leaves and acorns. ${ }^{2}$ Similarly at Dodona, the most famous sanctuary of the oak in Greece, the image of Zeus appears to have worn a chaplet of oak leaves ; for the god is constantly thus portrayed on coins of Epirus. ${ }^{3}$

Thus we may fairly assume that on certain solemn occasions Roman generals and magistrates personated the supreme god, and that in doing so they revived the practice of the early kings. To us moderns, for whom the breech which divides the human from the divine has deepened into an impassable gulf, such mimicry may appear impious. But it was otherwise with the ancients. To their thinking gods and men were akin, for many families traced their descent from a divinity, and the deification of a man probably seemed as little extraordinary to them as the canonisation of a saint appears to a modern Catholic. The Romans in particular were quite familiar with the spectacle of mortals masquerading as spirits ; for at the funerals of great houses all the illustrious dead of the family were personated by men specially chosen for their resemblance to the departed.

1 Ovid, Fasti, i. 607 sqq., iv. 953 sq. Tiberius refused a similar honour (Suetonius, Tiberius, 26); but Domitian seems to have accepted it (Martial, viii. 82. 7). Two statues of Claudius, one in the Vatican, the other in the Lateran museum, represent the emperor as Jupiter wearing the oak crown (W. Helbig, Fiihrer durch die öffentlichen Sammlungen klassischer Altertümer in Rom, ${ }^{2}$ i. Nos. 312, 673).

2 C.I.L. viii. No. $698 \mathrm{I}$.

3 J. Overbeck, Griechische Kunstmythologie, Besonderer Theil, i. 232 sqq.; L. R. Farnell, The Cults of the Greek States, i. 107 sq. 
These representatives wore masks fashioned and painted in the likeness of the originals : they were dressed in rich robes of office, resplendent with purple and gold, such as the dead nobles had worn in their lifetime : like them they rode in chariots through the city preceded by the rods and axes, and attended by all the pomp and heraldry of high station; and when at last the funeral procession, after threading its way through the crowded streets, defiled into the Forum, the maskers solemnly took their seats on ivory chairs, placed for them on the platform of the Rostra, in the sight of the people, recalling no doubt to the old, by their silent presence, the memories of an illustrious past, and firing the young with the ambition of a glorious future. ${ }^{1}$

According to a tradition which we have no right to reject, Rome was founded by settlers from Alba Longa, a city which stood on the slope of the Alban hills, overlooking Rome and the Campagna. ${ }^{2}$ Hence if the Roman kings claimed to be representatives or embodiments of Jupiter, the god of the sky, the thunder, and the oak, it is natural to suppose that the kings of Alba, from whom the founder of Rome traced his descent, may have set up the same claim before them. Now the Alban dynasty bore the name of Silvii, that is Woodmen, and it can hardly be without significance that in the vision of the historic glories of Rome revealed to Æneas in the underworld, Virgil, who was an antiquary as well as a poet, represents all the line

1 Polybius, vi. 53 \%.

2 As to the situation see Dionysius Halicarnasensis, Antiguit. Rom. i. $66 ; \mathrm{H}$. Nissen, Iralische Landestunde, ii. (Berlin, 1902), pp. $5^{82} 49$. 
of the Silvii or Woods as crowned with oak. ${ }^{1}$ A chaplet of oak leaves would thus seem to have been part of the insignia of the old kings of Alba Longa, as of their successors the kings of Rome ; in both cases it marked the monarch as the human representative of the oak god. With regard to Silvius, the first king of the Alban dynasty, we are told that he got his name because he had been born or brought up in the forest, and that when he came to man's estate he contested the kingdom with his kinsman Julus, whose name, as some of the ancients themselves perceived, means the Little Jupiter. The people decided in favour of Silvius, but his rival Julus was consoled for the loss of the crown by being invested with religious authority and the office of chief pontiff, or perhaps rather of Flamen Dialis, the highest dignity after the kingship. From this Julus or Little Jupiter the noble house of the Julii, and hence the first emperors of Rome, believed themselves to be sprung. ${ }^{2}$ The legend of the dispute between Silvius and Julus

1 Virgil, Aen. vi. 772.

2 Virgil, Aen. vi. 760 sq9., with the commentary of Servius; Livy, i. 3. 6 sqq.; Ovid, Metam. xiv. 609 sqq. ; id., Fasti, iv. 39 sqq.; Festus, s.v. " Silvi," p. 340, ed. C. O. Müller; Aurelius Victor, Origo gentis Romanae, I5-17; Dionysius Halicarnasensis, Antiquit. Rom. i. 70 ; Diodorus Siculus, vii. $3 a$ and $3 b$, vol. ii. pp. I 10112 , ed. L. Dindorf (Teubner text) ; Joannes Lydus, De magistratibus, i. 21. As to the derivation of the name Julus, see Aurelius Victor, op. cit. 15; Steuding, in W. H. Roscher's Lexikon d. griech. u. röm. Mythologie, ii. 574. Compare W. H. Lindsay, The Latin Language (Oxford, 1894), p. 250. According to Diodorus, the priesthood bestowed on Julus was the pontificate; but the name Julus or Little Jupiter suggests that the office was rather that of Flamen Dialis, who was a sort of living embodiment of Jupiter (see below, p. 215), and whose name of Dialis is derived from the same root as Julus. On the Julii and their relation to Vejovis, see R. H. Klausen, Aeneas und die Penaten, ii. 1059 sqg. I have to thank Mr. A. B. Cook for directing my attention to the Alban kings and their interesting legends. See his article, "Zeus, Jupiter, and the Oak," Classical Review, xviii. (1904), pp. $363 \mathrm{sq}$. 
may preserve a reminiscence of such a partition of spiritual and temporal powers in Alba Longa as afterwards took place in Rome, when the old regal office was divided between the Consuls and the King of the Sacred Rites. That the Julian house worshipped Vejovis or the Little Jupiter, according to the ancient rites of Alba Longa, is proved by the inscription on an altar which they dedicated to him at Bovillae, a colony of Alba Longa, situated at the foot of the Alban hills. ${ }^{1}$ The Cæsars, the most illustrious family of the Julian house, took their name from their long hair (caesaries), ${ }^{2}$ which was probably in those early days a symbol of royalty, just as it was among the Franks many ages afterwards.

But in ceding the high-priesthood to their rivals, it would seem that the reigning dynasty of the Silvii or Woods by no means renounced their own claim to personate the god of the oak and the thunder; for the Roman annals record that one of them, Romulus, Remulus, or Amulius Silvius by name, pretended to be a god in his own person, the equal or superior of Jupiter. To support his pretensions and overawe his subjects, he constructed machines whereby he mimicked

1 C.I.L. xiv. No. 2387 ; L. Preller, Römisshe Mythologie, ${ }^{3}$ i. 263 sq. On Vejovis as the Little Jupiter, see Festus, 8.v. "Vesculi," p. 379, ed. C. O. Müller ; Ovid, Fasti, iii. 429.448. At Rome the sanctuary of Vejovis was on the saddle between the two peaks of the Capitoline hill (Aulus Gellius, v. 12. 1 sq.; Ovid, Fassi, iii. 429 sq.); thus he appropriately dwelt on the same hill as the Great Jupiter, but lower down the slope. On some Roman coins he is represented by a youthful beardless head crowned with oak. See E. Babelon, Monnaies de la Republigue Romaine, i. 552, ii. 266, 529.

2 Festus, s.v. "Casar," p. 57, ed. C. O. Maller. Other but less probable explanations of the name are suggested by Aelius Spartianus (Helius, ii. 3 r.). 
the roll of thunder and the flash of lightning. Diodorus relates that in the season of fruitage, when thunder is loud and frequent, the king commanded his soldiers to drown the roar of heaven's artillery by clashing their swords against their shields. But he paid the penalty of his impiety; for he perished, he and his house, struck by a thunderbolt in the midst of a dreadful storm. Swollen by the rain, the Alban lake rose in flood and drowned his palace. But still, says an ancient historian, when the water is low and the surface unruffled by a breeze, you may see the ruins of the palace at the bottom of the clear lake. ${ }^{1}$ Taken along with the similar story of Salmoneus, king of Elis, this legend points to a real custom observed by the early kings of Greece and Italy, who, like their fellows in Africa down to modern times, may have been expected to produce rain and thunder for the good of the crops. The priestly king Numa passed for an adept in the art of drawing down lightning from the sky. ${ }^{2}$

In this connection it deserves to be noted that, according to the legend, Salmoneus, like his Alban counterpart, was killed by a thunderbolt ; and that one of the Roman kings, Tullus Hostilius, is reported to

1 Dionysius Halicarn. Antiquit. Rom. i. 71 ; Diodorus Siculus, in Eusebius, Chronic. bk. i. coll. 287, 289, ed. A. Schoene; Diodorus Siculus, vii. $3 a$ and 4 , vol. ii. pp. 112 sq., ed. L. Dindorf (Teubner text); Zonaras, Annal. vii. I; Aurelius Victor, Origo gentis Romanae, 18 ; Ovid, Metam. xiv. 616-618; id., Fasti, iv. 50; Livy, i. 3. 9. A tale of a city submerged in the Alban lake is still current in the neighbourhood. See the English translators' note to Niebuhr's History of Rome, ${ }^{3}$ i. 200. Similar stories are told in many lands. See my note on Pausanias, vii. 24. 6.

2 Pliny, Nat. Hist. ii. 140, xxviii. 13 sq. Compare Livy, i. 20. 7 ; Ovid, Fasti, iii. 285-348; Plutarch, Numa, 15 ; Arnobius, Adversus Nationes, v. 1-4. 
have met with the same end in an attempt to draw down Jupiter in the form of lightning from the clouds. ${ }^{1}$ Eneas himself, the legendary ancestor both of the Alban and the Roman kings, vanished from the world in a violent thunderstorm, and was afterwards worshipped as Jupiter Indiges. A mound of earth, encircled with fine trees, on the bank of the little river Numicius, was pointed out as his grave. ${ }^{2}$ Romulus, too, the first king of Rome, disappeared in like manner. It was the seventh of July, and the king was reviewing his army at the Goat's Marsh, outside the walls of the city. Suddenly the sky lowered and a tempest burst, accompanied by peals of thunder. Soon the storm had swept by, leaving the brightness and serenity of the summer day behind. But Romulus was never seen again. Those who had stood by him said they saw him caught up to heaven in a whirlwind; and not long afterwards a certain Proculus Julius, a patrician of Alban birth and descent, declared on oath that Romulus had appeared to him clad in bright armour, and had announced that the Romans were to worship him as a god under the name of Quirinus, and to build him a temple on the spot. The temple was built, and the place was thenceforth known as the Quirinal hill. ${ }^{3}$ If,

\footnotetext{
1 Pliny, Nar. Hist. ii. 140, xxviii. 14 ; Livy, i. 31.8 ; Aurelius Victor, De viris illustribus, 4 ; Zonaras, Annal. vii. 6.

${ }^{2}$ Livy, i. 2. 6 ; Ovid, Metam. xiv. 598.608 ; Pliny, Nat. Hist, iii. 56 ; Dionysius Halicarn. Ant. Rom. i. 64 ; Servius, on Virgil, Aen. i. 259 ; Aurelius Victor, Origo gent is Romanae, 14. Only the last writer mentions the thunderstorm.

s.ivy, i. 36 ; Cicero, De legibus, i. 1. 3 ; id., De re publica, i. 16. 25, ii. 10. 20; Ovid, Fassi, ii. 475.512 ; Plutarch, Romulus, 27 sq.; Dionysius Halicarn. Ant. Rom. ii. 56 and 63 ; Zonaras, Annal. vii. 4 ; Aurelius Victor, De viris illuseribus, 2 ; Florus, Epiroma, i. 8. 16-18.
} 
as Mr. A. B. Cook has conjectured ${ }^{1}$ and as seems to be philologically possible, the word Quirinus contains the same root as quercus, "an oak," the name of the deified Romulus would mean no more than "the oak god," that is, Jupiter. Thus the tradition would square perfectly with the other indications which have led us to conclude that the kings both of Alba and Rome claimed to be embodiments of Jupiter, the god of the sky, of thunder, and of the oak. Certainly the stories which associated the deaths of so many of them with thunderstorms point to a close connection with the deity of thunder and lightning. A king who had been wont to fulminate in his lifetime might naturally be supposed at death to be carried up in a thunderstorm to heaven, there to discharge above the clouds the same duties which he had performed on earth. Such a tale would be all the more likely to attach itself to the twin Romulus, if the early Romans shared. the widespread superstition that twins have power over the weather in general and over thunder and lightning in particular. That tempests are caused by the spirits of the dead is a belief of the Araucanians of Chili. Not a storm bursts upon the Andes or the ocean which these Indians do not ascribe to a battle between the souls of their fellowcountrymen and those of the Spaniards. In the roar of the wind they hear the trampling of the ghostly horses, in the peal of the thunder the roll of the drums, and in the flashes of lightning the fire of the artillery. ${ }^{2}$

I A. B. Cook, "Zeus, Jupiter, and the Oak," Classical Revierw, xviii. (1904), pp. 368 sq.

2 J. I. Molina, Geographical, Natural, and Civil History of Chili (London, 1809), 
Thus if the kings of Alba and Rome imitated Jupiter as god of the oak by wearing a crown of oak leaves, they seem also to have copied him in his character of a weather god by pretending to make thunder and lightning. And if they did so, it is probable that, like Jupiter in heaven and many kings on earth, they also acted as public rain-makers, wringing showers from the darkling sky by their enchantments whenever the parched earth cried out for the refreshing moisture. At Rome the sluices of heaven were opened by means of a sacred stone, and the ceremony appears to have formed part of the ritual of Jupiter Elicius, the god who elicits from the clouds the flashing lightning and the dripping rain. ${ }^{1}$ And who so fitted to perform the ceremony as the king, the living representative of the sky god?

The conclusion we have reached as to the kings of Rome and Alba probably holds good of all the kings of ancient Latium: each of them, we may suppose, represented or embodied the local Jupiter. For we ii. 92 sq. The savage Conibos of the Ucayali river in eastern Peru imagine that thunder is the voice of the dead (W. Smith and F. Lowe, Fourney from Lima so Para, London, 1836 , p. 240 ) ; and among them when parents who have lost a child within three months hear thunder, they go and dance on the grave, howling turn about (De St. Cricq, "Voyage du Perou au Brésil," Bullesin de la Sociéré de Gégraphie, vi., Paris, 1853, p. 294). Apparently they hear the sighs and groans of their lost child in the rumble of thunder.

1 Festus, s.vv. "Aquaelicium" and "Manalem lapidem," pp. 2, 128, ed. C. O. Maller; Nonius Marcellus, s.v. "Trullum," p. 637, ed. Quicherat ; Servius, on Virzil, Aen. iii. 175; Fulgentius, "Expos. serm. antiq." s.v. "Manales lapides," Aucrores Mythographi Latini, ed. Staveren (Leyden and Amsterdam, 1742), pp. 769 sq. For the connection of the rite with Jupiter Elicius, see O. Gilbert, Geschichre und Togographie der Stade Rom im Alecreum, ii. 154 sq. ; Aust, in W. H. Roscher's Lexikon d. griech. u. rom. Myshologie, ii. $657 \mathrm{sg}$. As to the connection of Jupiter with the rain-making ceremony (aquaelicium), the combined evidence of Petronius (Sas.",44) and Tertullian (Apologeticus, 40) seems to me conclusive. 
can hardly doubt that of old every Latin town or settlement had its own Jupiter, as every town and almost every church in modern Italy has its own Madonna; and like the Baal of the Semites the local Jupiter was commonly worshipped on high places. Wooded heights, round which the rain-clouds gather, were indeed the natural sanctuaries for a god of the sky, the rain, and the oak. At Rome he occupied one summit of the Capitoline hill, while the other summit was assigned to his wife Juno, whose temple, with the long flight of stairs leading up to it, has for ages been appropriately replaced by the church of St. Mary " in the altar of the sky" (in Araceli). ${ }^{1}$ That both heights were originally wooded seems certain, for down to imperial times the saddle which joins them was known as the place "between the two groves." 2 Virgil tells us that the hill top, where gilded temples glittered in his day, had been covered of old by shaggy thickets, the haunt of woodland elves and savage men, "born of the tree trunks and the heart of oak." 3 These thickets were probably composed of oaks, for the oak crown was sacred to Capitoline Juno as well as to Jupiter : ${ }^{4}$ it was to a sacred oak on the Capitol, as I have said, that Romulus fastened the spoils; and there is evidence that in early times oak woods clothed other of the hills on

1 Ovid, Fasti, i. 637 sq., vi. 183 sqq. ; Livy, vii. 28.4 sq.; Cicero, De divinatione, i. 45. ror ; Solinus, i. 21. Although the temple was not dedicated until 344 B.c., the worship of the goddess of the hill appears to have been very ancient. See H. Jordan, Topographie der Stadt Rum im Altertum, i. 2. pp. 109 sq.; W. H. Roscher, Lexikon d. griech. u. röm. Mythologie, ii. 592 sq.

2 Livy, i. 8. 5 ; Ovid, Fasti, iii. $43^{\circ}$; Dionysius Halicarnas. Ant. Rom. ii. 15.

3 Virgil, Aen. viii. 314-3 18, 347-354.

4 Plutarch, Quaest. Rom. 92. 
which Rome was afterwards built. I will spare you the details of the evidence, but there is one of them to which I must call your attention. An old grove of Vesta once skirted the foot of the Palatine hill on the side of the Forum, ${ }^{1}$ and it must surely have been a grove of oaks. For, in the first place, a fine ancient relief representing the temple of Vesta shows an oak tree growing beside it; and in the second place, most important of all, charred embers of the sacred vestal fire were discovered by Signor Boni a few years ago at the temple of Vesta, and a microscopic analysis of them has proved that they consist of the pith or heart of trunks or great branches of oak (quercus, not ilex). ${ }^{2}$ This very remarkable fact, which I learned from its illustrious discoverer during a winter spent in Rome, is of high importance for the understanding of the early religion, not only of the Romans, but of all the Latin peoples ; for every Latin town would seem to have had its vestal fire, and the discovery of the charred embers in the Forum raises a presumption that every vestal fire in Latium was fed with the wood of the sacred oak, the tree of the supreme god Jupiter. Indeed there is reason to think that all the branches of the Aryan family in Europe fed their sacred fires with oak wood;

1 Cicero, De divinarione, i. 45. 101.

2 G. Boni, in Norizie degli Scavi, May 1900, pp. 161,172 ; id., Aedes Vestac, p. 14 (extract from the Nuova Ansologia, ist August 1900). Commendatore Boni thinks that the charred remains of the wood prove that the fire was extinguished, probably by libations, and that therefore it cannot have been the perpetual holy fire of Vesta, which would have consumed the fuel completely. But a new fire was annually lit on the first of March (Ovid, Fassi, iii. 143 sq.; Macrobius, Sarurn. i. 12. 6), which may imply that the old fire was first ceremonially extinguished, as often happens in such cases. 
the old Lithuanians, for example, are known to have done this in honour of their chief god Perkunas, the deity of thunder and lightning, who corresponded to Zeus and Jupiter. ${ }^{1}$ According to some philologers the very name Perkunas means "the oak god," being derived from the root perq, which reappears in the Latin quercus, "an oak." 2

If the kings of Rome aped Capitoline Jupiter, their predecessors the kings of Alba probably laid themselves out to mimic the great Latian Jupiter, who had his seat above the city on the summit of the Alban Mountain. Latinus, the legendary ancestor of the dynasty, was said to have been changed into Latian Jupiter after vanishing from the world in the mysterious fashion characteristic of the old Latin kings. ${ }^{3}$ The sanctuary of the god on the top of the mountain was the religious centre of the Latin League, as Alba was its political capital till Rome wrested the supremacy from its ancient rival. Apparently no temple, in our sense of the word, was ever erected to Jupiter on this his holy mountain : as god of the sky and the thunder he appropriately received the homage of his worshippers in the open air. ${ }^{4}$ His oldest sanctuary on this airy

1 S. Grunau, Preussische Chronik, ed. M. Perlbach, i. (Leipsic, 1876), p. 78 (ii. tract. cap. v. §2); M. Praetorius, Deliciae Prussicae (Berlin, 1871), pp. I9 sq.

2 H. Hirt, "Die Urheimat der Indogermanen," Indogermanischen Forschungen, i. (1892), Pp. 479 sqq.; P. Kretschmer, Einleitung in die Geschichte der griechischen Sprache (Göttingen, I 896), pp. 8 I sq.

3 Festus, s.v. "Oscillantes," p. 194, ed. C. O. Muller.

${ }_{4}^{4}$.The massive wall, of which some remains still enclose the old garden of the Passionist monastery, seems to have been part of the sacred precinct which Tarquin the Proud, the last king of Rome, marked out for the solemn annual assembly of the Latin League. See Dionysius Halicarn. Ant. Rom. iv. 49 ; A. Schwegler, Römısche Geschichte, i. 341 ; H. Nissen, Italische La:deskunde, ii. 580. The 
spot was a grove ${ }^{1}$ and bearing in mind not merely the special consecration of the oak to Jupiter, but also the traditional oak crown of the Alban kings and the analogy of the oak of Capitoline Jupiter at Rome, we may suppose that the trees in the grove were oaks. ${ }^{2}$ We know that in antiquity Mount Algidus, an outlying group of the Alban hills, was covered with dark forests of oak both of the evergreen and the ordinary sort $;^{3}$ and among the tribes who belonged to the Latin League in the earliest days, and were entitled to share the flesh of the sacrificial white bull, there was one whose members styled themselves Men of the Oak, ${ }^{4}$ doubtless on account of the woods among which they dwelt.

But we should err if we pictured to ourselves the country as covered in historical times with an unbroken forest of oaks. Theophrastus has left us a description of the woods of Latium as they were in the fourth century before Christ. He says: "The land of the Latins is all moist. The plains produce laurels, myrtles,

Passionist monastery, founded in 1777 , by Cardinal York, the last of the Stuarts, has now been converted into a meteorological station and an inn (K. Baedeker, Central Italy and Rome, ${ }^{13}$ p. 400 ). It is fitting that the atmospheric phenomena should be observed by modern science on the same spot where they were worshipped by ancient piety.

1 Livy. i. 31. 3.

2 According to tradition, the sow which marked the future site of Alba Longa was found lying under evergreen oaks (Virgil, Aen. viii. 43), as Mr. A. B. Cook has pointed out (Classical Review, xviii. $3^{6} 3$ ). The tradition scems to show that the neighbourhood of the city was wooded with oaks.

3 Horace, Odes, iii. 23.9 sq., iv. 4.57 sqg.; compare id. i. 21.5 sq.

- Pliny, Nat. Hist. iii. 69; Dionysius Halicarn. Ant. Rom. v. 61. As to the white bulls sacrificed at the great Latin festival and partaken of by the members of the League, see Arnobius, Adversus Nationes, ii. 68 ; Dionysius Halicarn. Ant. Rom. iv. 49. Compare Cicero, De Plancio, ix. 23 ; Varro, De lingua Lafina, vi. 25. 
and wonderful beeches; for they fell trees of such a size that a single stem suffices for the keel of a Tyrrhenian ship. Pines and firs grow on the mountains. What they call the land of Circe is a lofty headland thickly wooded with oak, myrtle, and luxuriant laurels." 1 Thus the prospect from the top of the Alban Mount in the early age of Rome must have been very different in some respects from what it is to-day. The purple Apennines, indeed, in their eternal calm on the one hand, and the shining Mediterranean in its eternal unrest on the other, no doubt looked then much as they look now, whether bathed in sunshine or chequered by the fleeting shadows of clouds. But instead of the desolate brown expanse of the fever-stricken Campagna, spanned by its long lines of ruined aqueducts, like the broken arches of the bridge in the vision of Mirza, the eye must have ranged over woodlands that stretched away, mile after mile, on all sides, till their varied hues of green or autumnal scarlet and gold melted insensibly into the blue of the distant mountains and sea.

The Alban Mount was thus to the Latins what Olympus was to the Greeks, the lofty abode of the sky god, who hurled his thunderbolts from above the clouds. The white steers which were here sacrificed to him in his sacred grove, as on the Capitol at Rome, ${ }^{2}$ remind us of the white bulls which the Druids of Gaul sacrificed under the holy oak before they cut the

1 Theophrastus, Hist. Plant. v. 8. 3.

2 Arnobius, Adversus Nationes, ii. 68 ; Livy, xxii. 10. 7 ; Ovid, Ex Ponto, iv. 4. 31 ; Servius, on Virgil, Georg. ii. 146 ; Horace, Carmen Saeculare, 49. 
mistletoe $;^{1}$ and the parallel would be all the closer if, as we have reason to think, the Latins worshipped Jupiter originally in groves of oak. When we remember that the ancient Italian and Celtic people spoke languages which were nearly akin, ${ }^{2}$ we shall not be surprised at discovering traces of community in their religion, especially in what concerns the worship of the god of the oak and the thunder. For that worship belongs to the oldest stratum of the Aryan civilisation in Europe.

But Jupiter did not reign alone on the top of the Alban Mount. He had his consort with him, the goddess Juno, who was worshipped here under the same title, Moneta, as on the Capitol at Rome. ${ }^{3}$ As the oak crown was sacred to Jupiter and Juno on the Capitol, so we may suppose it was on the Alban Mount, from which the Capitoline worship was derived. Thus the oak god would have his oak goddess in the sacred oak grove. So at Dodona the oak Zeus was coupled with Dione, whose very name is only a dialectically different form of Juno ; ${ }^{4}$ and so on the top of Mount Cithaeron, as we saw in the last lecture, the god was periodically wedded to an oaken image of Hera. It is probable,

1 Pliny, Nat. Hist. xvi. 250 sq.

2 "Italic and Keltic are so closely bound together by important phonetic and morphological affinities that they are sometimes spoken of as one branch" of Aryan speech (J. H. Moulton, Two Lectures on the Science of Language, Cambridge, r903, p. 6 note). See also Isaac Taylor, The Origin of the Aryans, pp. 192, 257 ; P. Giles, Manual of Comparative Philology ${ }^{2}$ (London, 1901), p. 26.

${ }^{3}$ Livy, xlii. 7. 1, xlv. 16. 1. Compare Dio Cassius, xxxix. 20. 1. The temple was dedicated in 167 s.c., but the worship was doubtless far older.

- Strabo, vii. 7. 12 ; Hyperides, Or. iii. coll. 35-37, pp. 43 sq., ed. Blass; G. Curtius, Griech. Etymologie, p. 236 ; W. H. Roscher, Funo und Hera (Leipsic, 1875), pp. 17 sq. 
though it cannot be positively proved, that the sacred marriage of Jupiter and Juno was annually celebrated by all the peoples of the Latin stock in the month which they named after the goddess, the midsummer month of June. ${ }^{1}$ Now on the first of June the Roman pontiffs performed certain rites in the grove of Helernus beside the Tiber, and on the same day, and perhaps in the same place, a nymph of the grove, by name Carna, received offerings of lard and bean porridge. She was said to be a coy huntress who gave the slip to her suitors in the depth of the wood, but was caught by Janus. Some took her to be Diana herself. ${ }^{2}$ If she was indeed a form of that goddess, her union with Janus, that is, Dianus, would be appropriate; and as she had a chapel on the Cælian hill, which is known to have been once covered with oak woods, ${ }^{3}$ she may, like Egeria, have been an oak nymph. Further, Janus or Dianus, and Diana, as we shall see later on, were originally mere doubles of Jupiter and Juno, with whom they coincide in name and to some extent in

1 W. H. Roscher, op. cit. pp. 64 sqq.; id., Lexikon d. griech. u. rom. Myth. ii. 575 sq., 591 sqq. See particularly Ovid, Amores, iii. 13 ; Dionysius Halicarn. Ant. Rom. i. 21. The month of June was variously known in different parts of Latium as Funius, Funonius, and $\mathcal{F}$ unonalis. See Ovid, Fasti, vi. 59-63; Macrobius, Sat. i. 12. 30; Festus, p. 103, ed. C. O. Müller. The two latter forms seem to render the derivation of $\mathcal{F}_{\text {unius }}$ from $\mathcal{F}$ uno quite certain.

2 Ovid, Fasti, vi. 101-168; Macrobius, Sut. i. 12.31-33; Tertullian, Ad Nationes, ii. 9; Varro, quoted by Nonnus, De varia significatione verborum, p. 390 , ed. Quicherat.

3 Tacitus, Annals, iv. 65. The Porta 2uerquetulana or 2uerquetularia, "the Gate of the Oak Grove," seems to have been between the Cælian and the Esquiline hills (Pliny, Nat. Hist. xvi. 37 ; Festus, pp. 260, 261, ed. C. O. Muller); and close by there was a chapel of the Oak Grove dedicated to the worship of the oak nymphs (Festus, llcc.; Varro, De lingua Latina, v. 49). These nymphs are represented on coins (E. Babelon, Monnaies de la Republique Romaine, i. 99 sq.). 
function. Hence it appears to be not impossible that the rite celebrated by the pontiffs on the first of June in the sacred grove of Helernus was the marriage of Jupiter and Juno under the forms of Janus and Diana. It would be some confirmation of this view if we could be sure that, as Ovid seems to imply, the Romans were in the habit of placing branches of white thorn or buckthorn in their windows on the first of June to keep out the witches $;^{1}$ for in some parts of Europe precisely the same custom is observed, for the same reason, a month earlier, on the marriage day of the King and Queen of May. ${ }^{2}$ However, the evidence as to the rites observed by the Romans on the first of June is too slight and dubious to allow us to press the parallel with May Day.

If at any time of the year the Romans celebrated the sacred marriage of Jupiter and Juno, as the Greeks commonly celebrated the corresponding marriage of Zeus and Hera, we may suppose that under the Republic the ceremony was either performed over images of the divine pair or acted by the Flamen Dialis and his wife the Flaminica. For the Flamen Dialis was the priest of Jove; indeed ancient and modern writers have regarded him, with much probability, as a living image of Jupiter, a human embodiment of the sky god. ${ }^{3}$ In earlier times the Roman king, as repre-

1 Ovid, Fassi, vi. 129-168.

2 The evidence will be given in the third edition of The Golden Bough.

3 Plutarch, 2uaest. Rom. 111; L. Preller, Römische Mythologie, ${ }^{3}$ i. 201 ; F. B. Jevons, Plusarsh's Romane 2uessions, p. Ixxiii.; C. Julian, in Daremberg et Saglio, Dicsionnaire des Ansizuites Grecques ef Romaines, ii. $\$ 156$ s.9. 
sentative of Jupiter, would naturally play the part of the heavenly bridegroom at the sacred marriage, while his queen would figure as the heavenly bride, just as in Egypt the king and queen masqueraded in the character of deities, and as at Athens the queen annually wedded the vine god Dionysus. Even if the office of Flamen Dialis existed under the kings, as it appears to have done, the double representation of Jupiter by the king and the flamen need not have seemed extraordinary to the Romans of the time. The same sort of duplication, as we saw, appears to have taken place at Alba, when the Julii were allowed to represent the supreme god in the character of Little Jupiters, while the royal dynasty of the Silvii continued to wield the divine thunder and lightning. And long ages afterwards, history repeating itself, another member of the Julian house, the first Emperor of Rome, was deified in his lifetime under the title of Jupiter, while a flamen was appointed to do for him what the Flamen Dialis did for the heavenly Jove. ${ }^{1}$ It is said that Numa, the typical priestly king, at first himself discharged the functions of Flamen Dialis, but afterwards appointed a separate priest of Jupiter with that title, in order that the kings, untrammelled by the burdensome religious observances attached to the priesthood, might be free to lead their armies to battle. ${ }^{2}$ The tradition may be substantially correct; for analogy shows that the functions of a priestly king are too

1 Cicero, Philippics, ii. 43. 110; Suetonius, Divus Fulius, 76 ; Dio Cassius, xliv. 6. The coincidence has been pointed out by Mr. A. B. Cook (Classical Revierw, xviii. 371 ).

2 Livy, i. 20. I sq. 
harassing and too incongruous to be permanently united in the same hands, and that sooner or later the holder of the office seeks to rid himself of part of his burden by deputing to others, according to his temper and tastes, either his civil or his religious duties. Hence we may take it as probable that the fighting kings of Rome, tired of parading as Jupiter and of observing all the tedious restrictions which the character of godhead entailed on them, were glad to relegate these pious mummeries to a substitute, in whose hands they left the crosier at home while they went forth to wield the sharp Roman sword abroad. This would explain why the traditions of the later kings, from Tullus Hostilius onwards, exhibit so few traces of sacred or priestly functions adhering to their office. Among the ceremonies which they henceforward performed by deputy may have been the rite of the sacred marriage.

Whether that was so or not, the legend of Numa and Egeria appears to embody a reminiscence of a time when the priestly king himself played the part of the divine bridegroom; and as we have seen reason to suppose that the Roman kings personated the oak god, while Egeria is expressly said to have been an oak nymph, the story of their union in the sacred grove raises a presumption that at Rome in the regal period a ceremony was periodically performed exactly analogous to that which was annually celebrated at Athens down to the time of Aristotle. The marriage of the king of Rome to the oak goddess, like the wedding of the vine god to the Queen of Athens, must have been intended 
to quicken the growth of vegetation by homœopathic magic. Of the two forms of the sacred marriage we can hardly doubt that the Roman was the older, and that long before the northern invaders met with the vine on the shores of the Mediterranean, their forefathers had married the oak god to the oak goddess in the vast forests of central and northern Europe. In the England of our day the forests have mostly disappeared, yet still on many a village green and in many a country lane a faded image of the sacred marriage lingers in the rustic pageantry of May Day.

So much for the custom of marrying human beings to deities, especially to deities of vegetation and water. But there is another case of that custom which we must now briefly consider, namely, the practice of marrying women to the god of the fire. This practice is of some importance for the understanding of the early history of the Latins, since there are grounds for thinking that the old Latin kings were commonly supposed to be sons of the fire god by a mortal mother. The evidence which has led me to this conclusion is as follows.

First, let us take the legend of the birth of King Servius Tullius. It is said that one day the virgin Ocrisia, a slave-woman of Queen Tanaquil, was offering as usual cakes and libations on the royal hearth when a flame shot out towards her from the fire. Taking this for a sign that her handmaiden was to be the mother of a more that mortal son, the wise Queen Tanaquil bade the girl array herself as a bride and lie 
down beside the hearth. Her orders were obeyed: Ocrisia conceived by the god or spirit of the fire, and in due time brought forth Servius Tullius, the future king of Rome, who was thus born a slave, being the reputed son of a slave mother and a divine father, the fire god. His birth from the fire was attested in his childhood by a flame that played about his head as he slept at noon in the king's palace. ${ }^{1}$ This story, as others have pointed out before, ${ }^{2}$ seems clearly to imply that the mother of Servius Tullius was a Vestal Virgin charged with the care and worship of the sacred fire in the king's house. Now in Promathion's History of Italy, cited by Plutarch, a similar tale was told of the birth of Romulus himself, the founder of Rome. It is said that in the house of the king of Alba a flame of a mysterious shape hung over the hearth for many days. Learning from an oracle that a virgin should conceive by this phantom and bear a son of great valour and renown, the king ordered one of his daughters to take the fiery apparition for her husband; but she disdained to do so and sent her handmaid instead. The handmaid complied, and became the mother of Romulus and Remus. The king, angry at his daughter's disobedience, would have put her and her slave-woman to death, but the lives of the girls were saved by the interposition of the goddess Vesta in a dream. ${ }^{3}$ In

'Plutarch, De forsuna Romanorum, 10; Dionysius Halicarn. Ant. Rom. iv. 1 sq.; Ovid, Fasti, vi. 627-636 ; Pliny, N'at. Hist. ii. 241, xxxvi. 204; Livy, i. 39 ; Servius, on Virgil, Aen. ii. 683 ; Arnobius, Adversus Nationes, vi. 18.

${ }^{2}$ A. Schwegler, Romische Geschichee, i. 715 ; L. Preiler, Römische Myshologie, ${ }^{3}$ ii. 344 .

3 P'utarch, Romulus, 2. 
this legend, as in the story of the birth of Servius Tullius, it is plain that the mother of the future king of Rome was both a slave and a Vestal Virgin. Orthodox Roman tradition always admitted that she was a Vestal, but naturally enough represented her as the king's daughter rather than his slave. ${ }^{1}$ However, when we compare this legend with the similar story of the birth of Servius Tullius, we may suspect that Plutarch's authority, Promathion, has preserved the genuine tradition, and a very remarkable one it is ; he has, in fact, betrayed the secret that in the old days one of the king's parents might be, and sometimes was, a slave. At all events, such tales bear witness to an old belief that the early Roman kings were born of virgins and of the fire. Similarly, Cæculus, the founder of Præneste, passed for a son of Vulcan. It was said that his mother conceived him through a spark, which leapt from the fire and struck her as she sat by the hearth. She exposed the child near a temple of Jupiter, and he was found there beside a fire by some maidens who were going to draw water. In after life he proved his divine birth by working an appropriate miracle. When an infidel crowd refused to believe that he was the son of a god, he prayed to his father, and immediately the unbelievers were encircled with a flame of fire. ${ }^{2}$

More than this, the whole of the Alban dynasty appear to have traced their descent from a Vestal ; for

1 Dionysius Halicarn. Ant. Rom. i. 76 sq.; Livy, i. 3 sq.; Plutarch, Romulus, 3 ; Zonaras, Annal. vii. 1 ; Justin, xliii. 2. 1-3.

2 Servius, on Virgil, Aen. vii. 678. 
the wife of King Latinus, their legendary ancestor, was named Amata or Beloved, ${ }^{1}$ and this was the regular title bestowed on a Vestal after her election, ${ }^{2}$ a title which cannot be fully understood except in the light of the foregoing traditions, which seem to show that the Vestals were supposed to be beloved by the fire god. Moreover, fire is said to have played round the head of Amata's daughter Lavinia, ${ }^{3}$ just as it played round the head of the fire-born Servius Tullius. As the same prodigy was reported of Julus or Ascanius, the son of Æneas, ${ }^{4}$ we may suspect that a similar legend was told of his miraculous conception at the hearth. In short, the old Latin kings appear to have been regularly regarded as sons of the fire god by Vestal Virgins, who were believed to be the god's wives. That belief would explain why during their term of office the Vestals had to remain strictly celibate : the bride must be true to her divine bridegroom. And the difficulty of reconciling the theory of celibacy with the practice of motherhood is easily overcome by the custom of allowing a man to masquerade as a god at the sacred marriage, just as in Egypt the king disguised himself as a god when he wedded the queen. Thus the doctrine of the divine birth of kings, which was strictly held in ancient Egypt, presents no serious difficulty to

1 Virgil, Aen. vii. 343 .

2 Aulus Gellius, i. 12. 14 and 19. Compare L. Preller, Romische Myshologie, ${ }^{3}$ ii. 161, 344. There was a very ancient worship of Vesta at Lavinium, the city named after Amata's daughter Lavinia, the ancestress of the Alban kings. See Servius, on Virgil, Aen. ii. 296 ; Macrobius, Sarurn. iii. 4. 11.

3 Virgil, Aen. vii. 7 1-77.

4 Ibid. ii. 680-686. 
people who believe that a god may become incarnate in the form of a man, and that a virgin may conceive and bear him a son. I need hardly say that the theory of the divine motherhood of the Vestals applies only to the early regal and therefore prehistoric period. Under the Republic the demand for kings had ceased and with it therefore the supply. Yet a trace of the old view of the Vestals as virgin mothers lingered down to the latest times in the character of Vesta herself, their patroness and type; for Vesta always bore the official title of Mother, never that of virgin. ${ }^{1}$ We may surmise that a similar belief and practice once obtained in Attica. For Erichthonius, king of Athens, is said to have been a son of the fire god Hephæstus by the virgin goddess Athena: the story of his miraculous birth from the earth is clearly a later version devised to save the virginity of his mother. ${ }^{2}$

The relation of the Latin kings to the Vestals and their sacred fire is full of interest, and I might dwell on it much longer; but time presses and I must hurry on. Before quitting the subject I will take notice of some evidence that among the Celts, as among the early Latins, perpetual sacred fires were maintained by Vestal Virgins. We know from Solinus that in our own country perpetual fires were kept up in the temple of a goddess whom the Romans identified with

1 Virgil, Georg. i. 498; Ovid, Fasti, iv. 828; G. Henzen, Acta fratrum Arralium, pp. 124, 147 ; H. Dessau, Inscriptiones Latinae Selectae, Nos. 5047, 5048. Ennius represented Vesta as the mother of Saturn and Titan. See Lactantius, Divin. Inst. i. 14.

2 Apollodorus, iii. 14. 6 ; Schol. on Homer, Iliad, ii. 547 ; J. Tzetzes, Chiliades, v. 669 s7.; Augustine, De civitate dei, x viii. 12. 
Minerva, ${ }^{1}$ but whose native Celtic name appears to have been Brigit. Like Minerva, Brigit was a goddess of poetry and wisdom, and she had two sisters, also called Brigit, who presided over leechcraft and smithcraft respectively. This appears to be only another way of saying that Brigit was the patroness of bards, physicians, and smiths. $^{2}$ Now, at Kildare in Ireland the nuns of St. Brigit, or St. Bridget as she is also called, tended a perpetual holy fire down to the suppression of the monasteries under Henry VIII.; and we can hardly doubt that in doing so they merely kept up, under a Christian name, an ancient pagan worship of Brigit in her character of a fire goddess or patroness of smiths. The nuns were nineteen in number. Each of them had the care of the fire for a single night in turn; and on the twentieth evening the last nun, having heaped wood on the fire, used to say, "Brigit, take charge of your own fire; for this night belongs to you." She then went away, and next morning they always found the fire still burning and the usual quantity of fuel consumed. Like the vestal fire at Rome in the old days, the fire of St. Brigit burned within a circular enclosure made of stakes and brushwood, and no male might set foot inside the fence. The nuns were allowed to fan the fire or to blow it up with bellows, but they might not blow on it with their breath.

\footnotetext{
1 Solinus, xxii. 10. The Celtic Minerva, according to Cxsar (De Bello Gallico, vi. 17), was a goddess of the mechanical arts.

${ }^{2}$ J. Rhys, Celtic Hewshendom, pp. 73-77 ; P. W. Joyce, Social History of Ancient Ireland, i. 260 sq.

${ }^{3}$ Giraldus Cambrenis, The Topography of Ireland, chaps. 34-36, translated by 'Thomas Wright ; P. W. Joyce, Social History of Ireland, i. 334 r. It is said that
} 
Similarly it is said that the Balkan Slavs will not blow with their mouths on the holy fire of the domestic hearth : ${ }^{1}$ a Brahman is forbidden to blow a fire with his mouth $;^{2}$ and among the Parsees the priests have to wear a veil over their lips lest they should defile the sacred fire with their breath. ${ }^{3}$ At Arkon, in the island of Rügen, there was a shrine so holy that none but the priest might enter it, and even he might not breathe in it. As often as he needed to draw breath or give it out, he used to run out of the door lest he should taint the divine presence by inhaling or exhaling the air. ${ }^{4}$

In Ireland the custom of maintaining a perpetual fire was not peculiar to Kildare, but seems to have been common; for the native records show that such fires were kept up in several monasteries, in each of which a small church or oratory was set apart for the purpose.

in the island of Sena (the modern Sein), off the coast of Brittany, there was an oracle of a Gallic deity whose worship was cared for by nine virgin priestesses. They could raise storms by their incantations and turn themselves into any animals they pleased (Mela, iii. 48); but it is not said that they maintained a perpetual holy fire, though Ch. Elton affirms that they did (Origins of English History, p. 27). Mr. S. Reinach dismisses these virgins as a fable based on Homer's description of the isle of Circe (Odyssey, x. 135 sq9.), and he denies that the Gauls employed virgin priestesses (Cultes, Mythes, et Religions, i. (Paris, 1905), pp. 195-203). To me the nuns of St. Brigit seem to be most probably the successors of a Celtic order of Vestals charged, like the Roman Vestals, with the maintenance of a holy fire. That there were female Druids is certain, but it does not appear whether they were virgins. See Lampridius, Alexander Severus, 60; Vopiscus, Aurelianus, 44 ; id., Numerianus, 14 sq.

1 Prof. V. Titelbach, "Das heilige Feuer bei den Balkanslaven," Internationales Archiv für Ethnographie, xiii. (1900), p. I.

2 Laws of Manu, iv. 53, translated by G. Buhler.

3 Martin Haug, Essays on the Sacred Language, Writings, and Religion of the Parsees $^{3}$ (London, 1884), p. 243 , note 1 . Strabo describes (xiv. 3. 15) the mouthveil worn by the Magian priests in Cappadocia.

4 Saxo Grammaticus, Historia Danica, bk. xiv. p. 824, ed. P. E. Müller (p. 393 of Elton's translation). 
This was done, for example, at the monasteries of Seirkieran, Kilmainham, and Inishmurray. ${ }^{1}$ We may conjecture that these holy fires were merely survivals of the perpetual fires which in heathen times had burned in honour of Brigit. The view that Brigit was a fire goddess is confirmed by the observation that in the Christian calendar her festival falls the day before Candlemas, and the customs observed at that season by Celtic peasantry seem to prove that she was a goddess of the crops as well as of fire. ${ }^{2}$ If that was so, it is another reason for comparing her to Vesta, whose holy virgins, as we know from Ovid, performed ceremonies every year to fertilise both the earth and the cattle. ${ }^{3}$ Lastly, there are grounds for connecting Brigit, like Vesta, with the oak; for at Kildare her Christian namesake, St. Brigit or St. Bridget, built her church under an oak tree, which existed till the tenth century and gave its name to the spot; for Kildare is Cill-dara, "the church of the oak." 4 A tradition of the oak lingers in the lines:

\section{That oak of Saint Bride, which nor Devil nor Dane Nor Saxon nor Dutchman could rend from ber fane. ${ }^{5}$}

"The church of the oak" may well have displaced a temple or sanctuary of the oak, where in Druidical

' P. W. Joyce, Social History of Ancient Ireland, i. 335 sq.; Standish H. O'Grady, Sylva Gadelica, translation (London, 1892), pp. 15, 16, 41 .

2 The Golden Bough, 2 i. 223 ; J. G. Campbell, Witchcraft and Second Sight in the Highlands and Islands of Scotland (Glasgow, 1902), pp. 247 sq.; J. Train, Hissorical and Stasistical Account of the Isle of Man (Douglas, 1845), ii. 116 .

3 Ovid, Fasti, iv. 629-672, $731-782$.

- Douglas Hyde, A Liscrary Hissory of Ireland (London, 1899 ), p. 158.

${ }^{5}$ Quoted by Mr. D. Fitzgerald, in Revue Celigue, iv. (1879-1880), p. 193. 
times the hallowed fire was fed, like the vestal fire at Rome, with the wood of the sacred tree.

We may suspect that a conversion of this sort was often effected in Ireland by the early Christian missionaries. The monasteries of Derry and Durrow, founded by St. Columba, were both named after the oak groves in which they were built; and at Derry the saint spared the beautiful trees and strictly enjoined his successors to do the same. In his old age, when he lived as an exile on the shores of the bleak and stormswept isle of Iona, his heart yearned to the home of his youth among the oak groves of Ireland, and he gave expression to the yearning in passionate verses which have come down to us :

That spot is the dearest on Erin's ground, For the treasures that peace and purity lend, For the hosts of bright angels that circle it round, Protecting its borders from end to end.

The dearest of any on Erin's ground, For its peace and its beauty I gave it my love; Each leaf of the oaks around Derry is founa To be crowded with angels from heaven above.

My Derry! my Derry! my little oak grove, My dwelling, my home, and my own little cell,

May God the Eternal in Heaven above Send death to thy foes, and defend thee well.1

Far from the oaks of Erin and the saint's last home among the stormy Hebrides, a sacred fire has been tended by holy virgins, with statelier rites and in more solemn fanes, under the equinoctial line. The Incas 
of Peru, who deemed themselves the children of the Sun, procured a new fire from their great father at the solstice in June, our Midsummer Day. They kindled it by holding towards the Sun a hollow mirror, which reflected his beams on a tinder of cotton wool. But if the sky happened to be overcast at the time, they made the new fire by the friction of two sticks; and they looked on it as a bad omen when they were obliged to do this, for they said the Sun must be angry with them, since he refused to kindle the flame with his own hand. The sacred fire, however obtained, was deposited in Cuzco, the capital of Peru, in the temple of the Sun, and also in a great convent of holy virgins, who guarded it carefully throughout the year, and it was an evil augury if they suffered it to go out. These virgins were regarded as the wives of the Sun, and they were bound to perpetual celibacy. If any of them proved unfaithful to her husband the Sun, she was buried alive, like a Roman Vestal, and her guilty paramour was strangled. The reason for putting her to death in this manner was probably, as at Rome, a reluctance to shed royal blood; for all these virgins were of the royal family, being daughters of the Incas or his kinsmen. Besides tending the holy fire, they had to weave and make all the clothes worn by the Inca and his wife, to bake the bread that was offered to the Sun at his great festivals, and to brew the wine which the Inca and his family drank on these occasions. All the furniture of the convent, down to the pots, pans, and jars, was of gold and silver, just as in the temple of 
the Sun, because the virgins were deemed to be his wives. And they had a golden garden, where the very clods were of fine gold; where golden maize reared its stalks, leaves, and cobs, all of the same precious metal ; and where golden shepherds, with slings and crooks of gold, tended golden sheep and lambs. ${ }^{1} \quad$ The analogy of these virgin guardians of the sacred flame furnishes an argument in favour of the theory maintained in this lecture; for if the Peruvian Vestals were the brides of the sun, may not the Roman Vestals have been the brides of the fire?

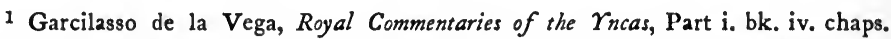
I-3, bk. vi. chaps. 20-22 (vol. i. pp. 292-299, vol. ii. pp. 155-I64, Markham's translation); P. de Cieza de Leon, Travels, p. 134 (Markham's translation); id., Second Part of the Chronicle of Peru, pp. 85 sq. (Markham's translation); Acosta, Natural and Moral History of the Indies, bk. v. ch. 15 (vol. ii. Pp. 331-333, Hakluyt Society). 


\section{LECTURE VIII}

Succession to Latin kingship in female line through marriage with king's daughter-Indifference to paternity of kings-African parallels-Sons of kings go abroad and reign in their wives' country-Succession to kingdom through marriage with late king's widow-Evidence of female kinship among European peoples-Roman kings of plebeian or indigenous race-Abolition of kingship at Rome a patrician revolution-Attempt of Tarquin the Proud to alter succession from female to male line-Roman sovereignty partly hereditary, partly elective-Personal qualities required in candidates for kingship - Possession of princess and of crown determined by athletic contest-King's Flight at Rome.

IN the last lecture I adduced some grounds for thinking that the early Latin kings personated the great god Jupiter and mimicked him by attempting to make rain, thunder, and lightning; further, that they went through a form of sacred marriage to ensure the fertility of the earth ; and lastly, that they often passed for sons of the fire god by Vestal Virgins, who were deemed the fire god's wives.

But we have still to ask, What was the rule of succession to the kingdom among the old Latin tribes ? We possess two lists of Latin kings, both of them professedly complete. One is the list of the kings of Alba, and the other is the list of the kings of Rome. If 
we accept as authentic the list of the Alban kings, we can only conclude that the kingdom was hereditary in the male line, the son regularly succeeding his father on the throne. ${ }^{1}$ But this list, if it is not, as Niebuhr held, a late and clumsy fabrication, has somewhat the appearance of an elastic cord which ancient historians stretched in order to link Æneas to Romulus. ${ }^{2}$ Yet it would be rash to set these names aside as a chronological stopgap deliberately foisted in by later annalists. In early monarchies, before the invention of writing, tradition is remarkably retentive of the names of kings. The Baganda of Central Africa, for example, remember the names of more than thirty of their kings in an unbroken chain of twenty-two generations. ${ }^{3}$ Even the occurrence of foreign names among the Alban kings is not of itself sufficient to condemn the list as a forgery; for, as I shall show presently, this feature is explicable by a rule of descent which appears to have prevailed in many early monarchies, including that of Rome. Perhaps the most we can say for the history of the Alban kings is that their names may well be

1 For the list of the Alban kings see Livy, i. 3. 5-11 ; Ovid, Fasti, iv. 39-56 ; id., Metam. xiv. 609 sqq.; Dionysius Halicarn. Ant. Rom. i. 70 sq.; Eusebius, Chronic. bk. i. vol. i. coll. 273, 275, 285, 287, 289, 291, ed. A. Schoene; Diodorus Siculus, vii. $3^{\text {a }}$, ed. L. Dindorf; Sextus Aurelius Victor, Origo gentis Romanae, 17-19; Zonaras, Annales, vii. I.

2 See B. G. Niebuhr, History of Rome, i. 205-207; A. Schwegler, Rumische Geschichte, i. 339, 342-345. However, Niebuhr admits that some of the names may have been taken from older legends.

3 H. M. Stanley, Through the Dark Continent (London, 1878), i. 380 ; C. T. Wilson and R. W. Felkin, Uganda and the Egyptian Sudan (London, 1882), i. 197 ; Fr. Stuhlmann, Mit Emin Pascha ins Herz von Afrika (Berlin, 1894), pp. 192 sq.; J. Roscoe, "Further Notes on the Manners and Customs of the Baganda," Fournal of the Anthropological Institute, xxxii. (1902), p. 25, with plates i. and ii.; Sir Harry Johnston, The Uganda Protectorate, ii. 68 I sq. 
genuine, and that some general features of the monarchy, together with a few events which happened to strike the popular imagination, may have survived in the memory of the people until they found their way into written history. But no dependence can be placed either on the alleged years of their reigns, or on the hereditary principle which is assumed to have connected each king with his predecessor.

When we come to the list of the Roman kings we are on much firmer, though still slippery ground. According to tradition there were in all eight kings of Rome, ${ }^{1}$ and with regard to the five last of them, at all events, we can hardly doubt that they did really sit on the throne, and that the traditional history of their reigns is, in its main outlines, correct. ${ }^{2}$ Now it is very remarkable that though the first king of Rome, Romulus, is said to have been descended from the royal house of Alba, in which the kingship is represented as hereditary in the male line, not one of the Roman kings was immediately succeeded by his son on the throne. Yet several left sons or grandsons behind them. ${ }^{3}$ On the other hand, one of them was descended from a former king through his mother, not through

1 Romulus and Tatius reigned for a time together; after Romulus the kings were, in order of succession, Numa Pompilius, Tullus Hostilius, Ancus Marcius, the elder Tarquin, Servius Tullius, and Tarquin the Proud.

2 See A. Schwegler, Römische Geschichse, i. 579 \&q.

3 According to one account, Romulus had a son and daughter (Plutarch, Romulus, 14). Some held that Numa had four sons (Plutarch, Numa, 21). Ancus Marcius left two sons (Livy, i. 35. 1, i. 40 ; Dionysius Halicarn. Ant. Rom. iii. 72 sq., iv. 34. 3). Tarquin the Elder left two sons or grandeons (Livy, i. 46 ; Dionysius Halicarn. Ant. Rom. iv. 6 sg., iv. 28). 
his father, ${ }^{1}$ and three of them, namely, Tatius, the elder Tarquin, and Servius Tullius, were succeeded by their sons-in-law, ${ }^{2}$ who were all either foreigners or of foreign descent. ${ }^{3}$ This suggests that the right to the kingship was transmitted in the female line, and was actually exercised by foreigners who married the royal princesses. To put it in technical language, the succession to the kingship of Rome, and probably in Latium generally, would seem to have been determined by certain rules which have moulded early society in many parts of the world, namely, exogamy, beena marriage, and female kinship. Exogamy is the rule which obliges a man to marry a woman of a different clan from his own : beena marriage is the rule that he must

1 Pompilia, the mother of Ancus Marcius, was a daughter of Numa. See Cicero, De re publica, ii. 18. 33 ; Livy, i. 32. I; Dionysius Halicarn. Ant. Rom. ii. 76. 5, iii. 35.3 , iii. 36.2 ; Plutarch, Numa, 2 .

2 Numa married Tatia, the daughter of Tatius (Plutarch, Numa, 3 and 2r); Servius Tullius married the daughter of the elder Tarquin (Livy, i. 39.4); and Tarquin the Proud married Tullia, the daughter of Servius Tullius (Livy, i. 42. 1, i. 46.5 ).

3 Numa was a Sabine from Cures (Livy, i. 18 ; Plutarch, Numa, 3 ; Dionysius Halicarn. Ant. Rom. ii. 58). Servius Tullius, according to the common account, was the son of Ocrisia, a slave-woman of Corniculum (Livy, i. 39. 5 ; Dionysius Halicarn. Ant. Rom. iv. I); but according to the Etruscan annals he was an Etruscan, by name Mastarna, who came to Rome with his friend Cæles Vibenna, and, changing his name, obtained the kingdom. This was stated by the Emperor Claudius in a speech of which fragments are engraved on a bronze tablet found at Lyons. See Tacitus, Annals, ed. Orelli and Baiter, ${ }^{2}$ p. 342. The Emperor was an authority on Etruscan history, for he composed a Greek work on the subject in twenty books (Suetonius, Claudius, 42). The historical, or at least legendary, character of Mastarna and Cæles is vouched for by a painting inscribed with their names, which was found in 1857 in an Etruscan tomb at Vulci (G. Dennis, Cities and Cemeteries of Etruria, ${ }^{3}$ ii. 506 sq.). Lastly, Tarquin the Proud was a son of the elder Tarquin, who was an Etruscan from Tarquinii (Livy, i. 34 ; Cicero, De re publica, ii. 19 sq., $\S 34$ sq.). The foreign birth of their kings naturally struck the Romans themselves. See the speech put in the mouth of the elder Tarquin by Livy, i. 35.3, and the speech actually delivered by the Emperor Claudius (loc. cit.). 
leave the home of his birth and live with his wife's people $;^{1}$ and female kinship is the system of tracing relationship and transmitting the family name through women instead of through men. If these principles regulated descent of the kingship among the ancient Latins, the state of things in this respect would be somewhat as follows. The political and religious centre of each community would be the perpetual fire on the king's hearth, tended by Vestal Virgins of the royal clan. The king would be a man of another clan, perhaps of another town or even of another race, who had married a daughter of his predecessor and received the kingdom with her. The children whom he had by her would inherit their mother's name, not his: the daughters would remain at home: the sons, when they grew up, would go away into the world, marry, and settle in their wives' country, whether as kings or commoners. Of the daughters who stayed at home, some or all would be dedicated as Vestal Virgins for a longer or shorter time to the service of the fire on the hearth, and one of them would in time become the wife of her father's successor.

This hypothesis has the advantage of explaining in a simple and natural way some obscure features in the traditional history of the Latin kings. Thus the legends which tell how the kings were born of virgin

1 "In Ceylon, where the higher and lower polyandry coexist, marriage is of two sorts-Deega or Beena-according as the wife goes to live in the house and village of her husbands, or as the husband or husbands come to live with her in or near the house of her birth" (J. F. M'Lennan, Studies in Ancient History (London, 1886), p. 101). 
mothers and divine fathers become at least more intelligible. For stripped of their fabulous element such tales mean no more than that a child's father is unknown; and this uncertainty as to fatherhood is more easily compatible with a system of kinship which ignores paternity than with one which makes it allimportant.

If among the Latins the women of royal blood always stayed at home and received as their consorts men of another stock, and often of another country, who reigned as kings in virtue of their marriage with a native princess, we can understand not only why foreigners wore the crown at Rome, but also why foreign names occur in the list of the Alban kings. In a state of society where nobility is reckoned only through women, in other words, where descent through the mother is everything and descent through the father is nothing, no objection will be felt to uniting girls of the highest rank to men of humble birth, even to aliens or slaves, provided that in themselves the men appear to be suitable mates. What really matters is that the royal stock, on which the prosperity and even the existence of the people is supposed to depend, should be perpetuated in a vigorous and efficient form, and for this purpose it is necessary that the women of the royal family should bear children to men who are physically and mentally fit, according to the standard of early society, to discharge the important duty of fatherhood. Thus the personal qualities of kings at this stage of social evolution are deemed of vital 
importance. If they, like their wives, are of royal and divine descent, so much the better; but it is not essential that they should be so.

The hypothesis which we have been led to frame of the rule of succession to the Latin kingship will be confirmed by analogy if we can show that elsewhere, under a system of female kinship, the paternity of the kings is a matter of indifference; nay, that men who are born slaves may, like Servius Tullius, marry royal princesses and be raised to the throne. Now this is true of the Tshi-speaking peoples of the Gold Coast in West Africa. Thus in Ashantee, where the kingdom descends in the female line to the king's brothers and afterwards to the sons of his sisters in preference to his own sons, the sisters of the reigning monarch are free to marry whom they please, provided only that their husband be a strong and handsome man, in order that the kings whom he begets may be men of finer presence than their subjects. It matters not how humble may be the rank and position of the king's father. If the king's sisters, however, have no sons, the throne will pass to the king's own son, and failing a son, to the chief vassal or the chief slave. But in the Fantee country the principal slave succeeds to the exclusion of the son. So little regard is paid by these people to the lineage, especially the paternal lineage, of their kings. ${ }^{1}$ Yet Ashantee has attained a barbaric civilisation as high perhaps as that of any negro state, and probably not

1 T. E. Bowdich, Mission from Cape Coast Cassle $t 0$ Asbantee, New Edition (London, 1873), pp. 185, 204 sq. ; A. B. Ellis, The Tshi-speaking Peoples of the Gold Casst, pp. 287, 297 sq.; id., The Yorubarspeaking Peoples of she Slave Caast, p. 187. 
at all inferior to that of the petty Latin kingdoms at the dawn of history.

A trace of a similar state of things appears to survive in Uganda, another great African monarchy. For there the queen dowager and the queen sister are, or rather were, allowed to have as many husbands as they choose, and to dismiss them at the shortest notice. Yet these women are not allowed under pain of death to bear children. ${ }^{1}$ Both the licence they enjoy and the prohibition they are subject to may be explained if we suppose that formerly the kingdom descended, as it still does in Ashantee, first to the king's brothers and next to the sons of his sisters. For in that case the next heirs to the throne would be the sons of the king's mother and of his sisters, and these women might accordingly be allowed, as the king's sisters still are allowed in Ashantee, to mate with any handsome man who took their fancy, in order that their offspring might be men of regal port. But when the line of descent was changed from the female to the male line, in other words, when the kings were succeeded by their sons instead of by their brothers or their sisters' sons, then the king's mother and his sisters would be forbidden to bear children lest the descent of the crown to the king's own children should be endangered by the existence of rivals who, according to the old law of the kingdom, had a better right to the throne. We may surmise that the practice of putting the king's brothers to death at the

1 J. Roscoe, "Further Notes on the Manners and Customs of the Baganda," Fournal of the Anthropological Institute, xxxii. (1902), pp. 36, 67. 
beginning of his reign, which survived till Uganda passed under English protection, ${ }^{1}$ was instituted at the same time as the prohibition of child-bearing laid on the king's mother and sisters. The one custom got rid of existing rivals; the other prevented them from being born. That the kingship in Uganda was formerly transmitted in the female line is strongly indicated by the rule that the kings and the rest of the royal family take their totems from their mothers, whereas all the other people of the country get their totems from their fathers. ${ }^{2}$

In Loango the royal blood is traced in the female line, and here also the princesses are free to choose and divorce their husbands at pleasure. These husbands are nearly always plebeians ; for princes and princesses, who are very numerous and form a ruling caste, may not marry each other. The lot of a prince consort is not a happy one, for he is rather the slave and prisoner than the spouse of his imperious princess. When he goes out he is preceded by guards who drive away all women from the road where he is to pass. If in spite of these precautions he should by ill luck cast his eyes on a woman, the princess may have his head chopped off, and commonly exercises, or used to exercise, the right. This sort of libertinism, sustained by power, often carries women of the blood royal to the greatest excesses, and nothing is so much dreaded

1 C. T. Wilson and R. W. Felkin, Uganda and the Egyprian Sudan (London. 1882), i. 200 ; J. Roscoe, op. cit. p. 67.

2 J. Roscoe, op. cir. pp. 27, 62. 
as their anger. No wonder that commoners in general avoid the honour of a royal alliance. Only poor and embarrassed men seek it as a protection against their creditors and enemies. All the children of such a man by such a wife are princes and princesses, and any one of the princes may in time be chosen king; for in Loango the crown is not hereditary but elective. ${ }^{1}$ Thus it would seem that the father of the king of Loango is nearly always a plebeian, and often little better than a slave.

At Athens, as at Rome, we find traces of the same mode of succession to the crown by marriage with a royal princess; for two of the most ancient kings of Athens, namely, Cecrops and Amphictyon, are said to have married the daughters of their predecessors. ${ }^{2}$ This tradition is confirmed by the evidence, which I shall adduce presently, that at Athens male kinship was preceded by female kinship.

Further, if I am right in supposing that in ancient Latium the royal families kept their daughters at home and sent forth their sons to marry princesses and reign among their wives' people, it will follow that the male descendants would reign in successive generations over different kingdoms. Now this seems to have happened both in ancient Greece and in ancient Sweden; from which we may legitimately infer that it was a custom

\footnotetext{
1 Proyart's "History of Loango," in Pinkerton's Voyages and Travels, xvi. 570, 579 sq. ; A. Bastian, Die deutsche Expedition an der Loango Kliste, i. 197 sqq. 'The lot of a prince consort in Loango may have been mitigated since Proyart wrote in the eighteenth century.

2 Pausanias, i. 2. 6.
} 
practised by more than one branch of the Aryan stock in Europe. I have to thank my friend Mr. H. M. Chadwick for reminding me of the Greek, and for informing me of the Swedish evidence. Take, for instance, the great house of Æacus, the grandfather of Achilles and Ajax. Æacus himself reigned in Ægina, but his descendants, as Pausanias justly observes, "from the beginning went forth to other lands." 1 His son Telamon migrated to the island of Salamis, married the king's daughter, and reigned over the country. ${ }^{2}$ Telamon's son Teucer, in his turn, migrated to Cyprus, wedded the king's daughter, and succeeded his fatherin-law on the throne. ${ }^{3}$ Again, Peleus, another son of Æacus, quitted his native land and went away to Phthia in Thessaly, where he received the hand of the king's daughter, and with her a third of the kingdom. ${ }^{4}$ Of Achilles, the son of Peleus, we are told that in his youth he was sent to the court of Lycomedes, king of Scyrus, where he became the father of Neoptolemus by one of the princesses. ${ }^{5}$ The tradition seems to show that Achilles followed the custom of his family in seeking his fortune in a foreign land. His son Neoptolemus after him went away to Epirus, where he settled and became the ancestor of the kings of the country. ${ }^{6}$

\footnotetext{
1 Pausanias, ii. 29. 4.

${ }^{2}$ Diodorus Siculus, iv. 72. 7. According to Apollodorus (iii. 12.7), Cychreus, king of Salamis, died childless, and bequeathed his kingdom to Telamon.

3 J. Tzetzes, Schol, on Lycophron, 450. Compare Pausanias, ii. 29. 4.

4 A pollodorus, iii. 13. 1. According to Diodorus Siculus (iv. 72.6), the king of Phthia was childless, and bequeathed his kingdom to Peleus.

- Apollodorus, iii. 13.8; Hyginus, Fabulae, 96.

6 Pausanias, i. 11.1 sq.; Justin, xvii. 3.
} 
Again, Tydeus was a son of Eneus, the king of Calydon in Ætolia, but he went to Argos and married the king's daughter. ${ }^{1}$ His son Diomede migrated to Daunia in Italy, where he helped the king in a war with his enemies, receiving as his reward the king's daughter in marriage and part of his kingdom. ${ }^{2}$ As another example we may take the family of the Pelopidær, whose tragic fortunes the Greek poets never wearied of celebrating. Their ancestor was Tantalus, king of Sipylus in Asia Minor. But his son Pelops passed into Greece, won Hippodamia, the daughter of the king of Pisa, in the famous chariot race, and succeeded his father-in law on the throne. ${ }^{3}$ His son Atreus did not remain in Pisa, but migrated to Mycenæ, of which he became king $;^{4}$ and in the next generation Menelaus, son of Atreus, went to Sparta, where he married Helen, the king's daughter, and himself reigned over that country. ${ }^{5}$ Further, it is very notable that, according to the old lyric poets, Agamemnon himself, the elder brother of Menelaus, reigned not at Mycenæ but in Lacedæmon, the native land of his wife Clytæmnestra, and that he was buried at Amyclæ, the ancient capital of the country. ${ }^{6}$

Various reasons are assigned by ancient Greek

1 Apollodorus, i. 8. 5 .

2 Antoninus Liberalis, Transform. 37 ; Ovid, Metam. xiv. 459 sq., 510 sq. Compare Virgil, Aen. xi. 243 sqq.

3 Diodorus Siculus, iv. 73 ; Hyginus, Fabulae, 82-84 ; Servius, on Virgil, Georg. iii. 7 .

4 Thucydides, i. 9 ; Strabo, viii. 6. 19.

- Apollodorus, iii. 10. 8.

${ }^{6}$ Schol. on Euripides, Orestes, 46 ; Pindar, Pyth. xi. 31 sq.; Pausanias, iii. 19. 6 . 
writers for these migrations of the princes. A common one is that the king's son had been banished for murder. This would explain very well why he fled his own land, but it is no reason at all why he should become king of another. We may suspect that such reasons are afterthoughts devised by writers who, accustomed to the rule that a son should succeed to his father's property and kingdom, were hard put to it to account for so many traditions of kings' sons who quitted the land of their birth to reign over a foreign kingdom.

The evidence for the existence of a similar practice in the old royal families of Sweden is being collected by Mr. Chadwick; I shall not say more on that head at present.

Thus it would seem that among some Aryan peoples, at a certain stage of their social evolution, it has been customary to regard women and not men as the channels in which royal blood flows, and to bestow the kingdom in each successive generation on a man of another family, and often of another country, who marries one of the princesses and reigns over his wife's people. A common type of popular tale which relates how an adventurer, coming to a strange land, wins the hand of the king's daughter and the half or the whole of the kingdom, may well be a reminiscence or a real custom.

Where practices and ideas of this sort prevail, it is obvious that the kingship is merely an appanage of marriage with a woman of the blood royal. The old Danish historian Saxo Grammaticus puts this view of 
the kingship very clearly in the mouth of Hermutrude, a legendary queen of Scotland, and her statement is all the more significant because, as we shall see presently, it reflects the actual practice of the Pictish kings. "Indeed she was a queen," says Hermutrude, "and but that her sex gainsaid it, might be deemed a king ; nay (and this is yet truer), whomsoever she thought worthy of her bed was at once a king, and she yielded her kingdom with herself. Thus her sceptre and her hand went together." I Wherever a custom of this kind has prevailed, a man may clearly acquire the kingdom just as well by marrying the widow as the daughter of his predecessor. This is what Ægisthus did at Mycenæ, and what Hamlet's uncle Feng and Hamlet's successor Wiglet did in Denmark; all three slew their predecessors, married their widows, and then sat peacefully on the throne. ${ }^{2}$ The tame submission of the people to their rule would be intelligible, if they regarded the assassins, in spite of their crimes, as the lawful occupants of the throne by reason of their marriage with the widowed queens. Similarly Gyges murdered Candaules, king of Lydia, married his widow, and reigned over the country. ${ }^{3}$ Nor was this the only instance of such a succession in the history of Lydia. The wife of King Cadys conspired against his life with her paramour Spermus, and though her husband

1 Saxo Grammaticus, Historia Danica, bk. iv. p. 158, ed. P. E. Müller (p. 126 of Elton's translation, quoted in the text).

2 The story of Hamlet (Amleth) is told in a striking form by Saxo Grammaticus in the third and fourth books of his history. Mr. H. M. Chadwick tells me that Hamlet stands on the border-line between legend and history. Hence the main outlines of his story may be correct.

3 Herodotus, i. 7-13. 
recovered from the dose of poison which she administered to him, he died soon afterwards, and the conspirator married the widow and succeeded to the throne. ${ }^{1}$ These cases excite a suspicion that in the royal house of Lydia descent was traced in the female line, and the suspicion is strengthened by the legendary character of Omphale, the ancestress of the dynasty. For she is represented as a masculine and dissolute queen of the Semiramis type, who wore male attire and put all her lovers to death; while on the other hand her consort Hercules was her purchased slave, who was treated by her with indignity and went about dressed as a woman. ${ }^{2}$ This implies that the queen was a far more powerful and important personage than the king, as would naturally happen wherever it is the queen who confers royalty on her consort at marriage, instead of receiving it from him. Hence we may conjecture that Herodotus was wrong in saying that from Hercules to Candaules the crown of Lydia had descended for twenty-two generations from father to son. ${ }^{3}$

When Canute the Dane had been acknowledged king of England, he married Emma, the widow of his predecessor Ethelred, whose throne he had overturned and whose children he had driven into exile. The marriage has not unnaturally puzzled the historians; for Emma was much older than her second husband,

1 Nicolaus Damascenus, vi. frag. 49, in Fragmenta Hisforicorum Graecorum, ed. C. Muller, iii. 380.

2 Athenzus, xii. 11, pp. 515 f-516 b; Apollodorus, ii. 6. 3 ; Diodorus Siculus, iv. 31 ; Joannes Lydus, De magiserasibus, iii. 64; Lucian, Dialogi deorum, xiii. 2 ; Ovid, Heroides, ix. 55 s99.; Statius, Theb. x. 646-649.

2 Herodotus, i. 7 . 
she was then living in Normandy, and it is very doubtful whether Canute had ever seen her before she came to be his bride. All, however, becomes plain if, as the cases of Feng and Wiglet seem to show, it was an old Danish custom that marriage with a king's widow carried the kingdom with it as a matter of right. In that case the young but prudent Canute married the mature widow merely out of policy, in order to clinch, according to Danish notions, by a legal measure his claim to that crown which he had already won for himself by the sword. ${ }^{1}$

Among the Saxons and their near kinsmen the Varini it appears to have been a regular custom for the new king to marry his stepmother. Thus Hermigisil, king of the Varini, on his deathbed enjoined his son Radger to wed his stepmother in accordance with their ancestral practice, and his injunction was obeyed. ${ }^{2}$ Edbald, king of Kent, married his stepmother after the death of his father Ethelbert $;^{3}$ and as late as the ninth century Ethelbald, king of the West Saxons, wedded Judith, the widow of his father Ethelwulf. ${ }^{4}$ Such marriages are intelligible if we suppose that old Saxon as well as old Danish law gave the kingdom to him who married the late king's widow.

1 See E. A. Freeman, History of the Norman Conquest of England, i. ${ }^{3} 410-412$, 733-737. I am indebted to my friend Mr. Chadwick both for the fact and for its explanation.

2 Procopius, De bello Gothico, iv. 20 (vol. ii. p. 562, ed. Dindorf). This and the following cases of marriage with a stepmother are cited by $\mathrm{K}$. Weinhold, Deutscbe Frauen ${ }^{2}$ (Vienna, 1882), ii. 359 sq.

3 Bede, Historia Ecclesiastica gentis Angiorum, ii. 5. 102 ; compare i. 27.63.

4Prudentius Trecensis, "Annales," anno 858, in Pertz's Monumenta Germaniae Historica, i. 451; Ingulfus, Historia, quoted ibid. 
To the view that the right to the Latin kingship was derived from women and not from men, it may be objected that the system of female kinship is unknown among the Aryans, ${ }^{1}$ and that even if faint traces of it may be met with elsewhere, the last place in the world where we should look for it would be Rome, the stronghold of the patriarchal family. To meet this objection it is necessary to point to some facts which appear to be undoubted survivals among Aryan peoples of a custom of tracing descent through the mother only.

In Attica tradition ran that in old days paternity was unknown, until Cecrops, the first king of Athens, introduced the system of individual marriage. ${ }^{2}$ Little weight could be attached to this tradition if it were not supported to a certain extent by the Attic usage which always allowed a man to marry his half-sister by the same father, but not his half-sister by the same mother. ${ }^{3}$ Such a rule seems clearly to be a relic of a time when kinship was counted only through women. Again, the Epizephyrian Locrians in Italy traced all ancestral distinction in the female, not the male line. ${ }^{4}$ The Cantabrians of Spain seem also to have had female

1 This is in substance the view of Dr. W. E. Hearn (The Aryan Household, pp. 150-155) and of Prof. B. Delbruck ("Das Mutterrecht bei den Indogermanen," Preussische Fahrbicber, 1xxix. (1895), pp. 14-27).

2 Clearchus of Soli, quoted by Athenæus, xiii. 2, p. 555 d; John of Antioch, in Fragmensa Historicorum Graecorum, ed. C. Maller, iv. 547; Charax of Pergamus, ib. iii. $63^{8}$; J. Tzetzes, Schol. on Lycopbron, 11 ; id., Chiliades, v. 650-665; Suidas,

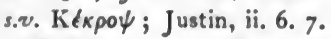

3 Philo Judxus, De specialibus legibus (vol. ii. p. 303, ed. Th. Mangey). See also Plutarch, Themissocles, 32 ; Cornelius Nepos, Cimon, 1; Schol. on Aristophanes, Clouds, 1371 ; L. Beauchet, Histoire du Drois Privé de la Ripublique Athenienne, i. (Paris, 1897), pp. 165 sq9. Compare Minucius Felix, Octavius, 31.

- Polybius, xii. 5 . 
kinship, for among them it was the daughters who inherited property and who portioned out their brothers in marriage. ${ }^{1}$

Further, the ancient Germans in the time of Tacitus deemed the tie between a man and his sister's children as close as that between a father and his own children; indeed, some regarded the bond as even closer and more sacred, and therefore in exacting hostages they chose the children of a man's sister rather than his own children, believing that this gave them a firmer hold on the family. ${ }^{2}$ The superiority thus assigned to the maternal uncle over the father is an infallible mark of female kinship, either present or past, as may be observed in very many African tribes to this day, among whom both property and political power pass, not from father to son, but from the maternal uncle to his nephews. ${ }^{3}$ Amongst the Germans in the time of Tacitus, it is true, a man's heirs were his own children, ${ }^{4}$ but the mother's brother could never have attained the position he held except under a system of maternal descent.

It is a moot point whether the Picts of Scotland belonged to the Aryan family or not $;^{5}$ but among

1 Strabo, iii. 4. I 8.

2 Tacitus, Germania, 20. Compare L. Dargun, Mutterrecht und Raubehe und ihre Reste im germanischen Recht und Leben (Breslau, 1883), pp. 21 sq.

3 A. B. Ellis, The Tshi-speaking Peoples of the Gold Coast, pp. 297 sq.; id., The Erwe-speaking Peoples of the Slave Coast, pp. 207 sqq.; Sir H. H. Johnston, British Central Africa, p. 471 ; A. Giraud-Teulon, Les origines du mariage et de la famille (Geneva and Paris, 1884), pp. 206 sqq.; A. H. Post, Afrikanische Furisprudenz, i. 13 sqq.

4 Tacitus, Germania, 20.

5 W. F. Skene held that the Picts were Celts (Celtic Scotland, i. 194-227). On the other hand, H. Zimmer supposes them to have been the pre-Celtic inhabitants of the British Islands. See his paper "Das Mutterrecht der Pikten," Zeitschrift 
them the kingdom was certainly transmitted through women. Bede tells us that down to his own time, in the early part of the eighth century, whenever a doubt arose as to the succession, the Picts chose their king from the female rather than the male line. ${ }^{1} \quad$ The statement is amply confirmed by historical evidence. For we possess a list of the Pictish kings and their fathers which was drawn up in the reign of Cenæd, king of the Scots, towards the end of the tenth century; and for the period from the year $5^{8} 3$ to the year 840 the register is authenticated by the Irish Annals of Tigernach and Ulster. Now, it is significant that in this list the fathers of the kings are never themselves kings; in other words, no king was succeeded on the throne by his son. Further, if we may judge by their names, the fathers of the Pictish kings were not Picts, but foreigners, men of Irish, Cymric, or English race. The inference from these facts seems to be that among the Picts the royal family was exogamous, and that the crown descended in the female line; in other words, that the princesses married men of another clan or even of another race, and that their issue by these strangers sat on the throne, whether they succeeded in a prescribed order according to birth, or were elected from among the sons of princesses, as the words of Bede might be taken to imply. ${ }^{2}$

der Savigny-Srifrung for Rechesgeschichee, xv. (1894), Romanistische Abtheilung, Pp. 209 s9g.

1 Bede, Historia Ecclesiastica gentis Anglorum, ii. 1. 7.

2 W. F. Skene, Celtic Scosland, i. 232-235 ; J. F. M'Lennan, Seudies in Ancient History (London, 1886), pp. 68-70; H. Zimmer, loc. cir. 
Another European, though not Aryan, people among whom the system of female kinship appears to have prevailed were the Etruscans. For in sepulchral inscriptions the name of the mother of the deceased is regularly recorded along with or even without the name of the father; and where the names of both father and mother are mentioned, greater prominence is given to the mother's name by writing it in full, whereas the father's name is, in accordance with Roman usage, merely indicated by an initial. ${ }^{1}$ The statement of Theopompus, that among the Etruscans paternity was unknown, ${ }^{2}$ may be only an exaggerated way of saying that they traced their descent through their mothers and not through their fathers. Yet apparently in Etruria, as elsewhere, this system of relationship was combined with a real indifference to fatherhood, and with the dissolute morals which that indifference implies. ${ }^{3}$ In these customs the Etruscans resembled the Lydians, and the similarity confirms the common opinion, which modern historians have too lightly set aside, that the Etruscans were of Lydian origin. 4 However that may be, in considering the vestiges of

1 K. O. Muller, Die Etrusker (Stuttgart, 1877), ii. 376 sq.; J. J. Bachofen, Die Sage von Tanaquil, pp. 282-290.

2 Theopompus, quoted by Athenæus, xii. 14, p. 517 de.

3 Plautus, Cistellaria, ii. 3. 20 sq.

4 Herodotus, i. 94 ; Strabo, v. 2. 2 ; Tacitus, Annals, iv. 55 ; Timæus, cited by Tertullian, De spectaculis, 5 ; Festus, s.v. "Turannos," p. 355, ed. C. O. Muller ; Plutarch, Romulus, 2; Velleius Paterculus, i. 1. 4 ; Justin, xx. 1. 7 ; Valerius Maximus, ii. 4. 4 ; Servius, on Virgil, Aen. i. 67. On the other hand, Dionysius of Halicarnassus held that the Etruscans were an indigenous Italian race, differing from all other known peoples in language and customs (Ant. Rcm. i. 26-30). On this much-vexed question, see K. O. Muller, Die Etrusker, i. 65 sqq.; G. Dennis, Cities and Cemeteries of Etruria, ${ }^{3}$ i. pp. xxxiii. sqq. 
female kinship among the Latins, we shall do well to bear in mind that the same archaic mode of tracing descent appears to have prevailed among the neighbouring Etruscans, who not only exercised a powerful influence on Rome, but gave her two, if not three, of her kings.

It would be neither unnatural nor surprising if among the ancient Latins female kinship survived in the royal family after it had been exchanged for male kinship in all others. For royalty, like religion, is essentially conservative; it clings to old forms and old customs which have long vanished from ordinary life. Thus in Uganda, as I have already mentioned, persons of royal blood still inherit their totems from their mothers, while other people inherit them from their fathers. So in Denmark and Scandinavia, as we have seen, the kingdom would appear to have been transmitted through women long after the family name and property had become hereditary in the male line among the common people.

Sometimes the difference in custom between kings and commoners is probably based rather on a distinction of race than on varying degrees of social progress; for a dynasty is often a family of alien origin who have imposed their rule on their subjects by force of arms, as the Normans did on the Saxons, and the Manchus on the Chinese. More rarely, perhaps, it may have happened that from motives of policy or superstition a conquering tribe has left a nominal kingship to the members of the old royal house. Such a concession 
would be most likely to be made where the functions of the king were rather religious than civil, and where the prosperity of the country was supposed to depend on the maintenance of the established relations between the people and the gods of the land. In that case the new-comers, not knowing how to appease and conciliate these strange deities, might be glad to let the priestly kings of the conquered race perform the quaint rites and mumble the old spells, which had been found to answer their purpose time out of mind. In a commonwealth like the Roman, formed by the union of different stocks, the royal family might thus belong either to the conquerors or to the conquered; in other words, either to the patricians or to the plebeians. But if we leave out of account Romulus and Tatius, who are more or less legendary figures, and the two Tarquins, who came of a noble Etruscan house, all the other Roman kings appear from their names to have been men of plebeian, not patrician, families. ${ }^{1}$ Hence it seems probable that they belonged to the indigenous race, who may have retained mother-right, at least in the royal succession, after they had submitted to invaders who knew father-right only.

If this was so, it confirms the view that the old Roman kingship was essentially a religious office; for the conquerors would be much more ready to leave an office of this sort in the hands of the conquered than a kingship of the type with which we are familiar. "Let these puppets," they might think, " render to the gods

1 H. Jordan, Die Könige im alten Italien (Berlin, 1884), pp. $15-25$. 
their dues, while we rule the people in peace and lead them in war." Of such priestly kings Numa was the type. But not all of his successors were willing to model themselves on his saintly figure, and, rejecting the pomps and vanities of earth, to devote themselves to communion with heaven. Some were men of strong will and warlike temper, who could not brook the dull routine of the cloister. They longed to exchange the stillness and gloom of the temple or the sacred grove for the sunshine, the dust, and the tumult of the battlefield. Such men broke bounds, and when they threatened to get completely out of hand and turn the tables on the patricians, it was time for them to go. This, we may conjecture, was the real meaning of the abolition of the kingship at Rome. It put an end to the solemn pretence that the state was still ruled by the ancient owners of the soil : it took the shadow of power from them and gave it to those who had long possessed the substance. The ghost of the monarchy had begun to walk and grow troublesome : the revolution laid it for centuries.

But though the effect of the revolution was to substitute the real rule of the patricians for the nominal rule of the plebeians, the break with the past was at the outset less complete than it seems. For the first two consuls were both men of the royal blood. One of them, L. Junius Brutus, was sister's son of the expelled King Tarquin the Proud. ${ }^{1}$ As such he would have been the heir to the throne under a strict system of

${ }^{1}$ Livy, i. 56. 7 ; Dionysius Halicarn. Ane. Rom. iv. 68. 1. 
female kinship. The other consul, L. Tarquinius Collatinus, was a son of the late king's cousin Egerius. ${ }^{1}$ These facts suggest that the first intention of the revolutionaries was neither to abolish the kingship nor to wrest it from the royal family, but merely, retaining the hereditary monarchy, to restrict its powers. To achieve this object they limited the tenure of office to a year, and doubled the number of kings, who might thus be expected to check and balance each other. But it is not impossible that both restrictions were merely the revival of old rules which the growing power of the kings had contrived for a time to set aside in practice. The legends of Romulus and Remus, and afterwards of Romulus and Tatius, may be real reminiscences of a double kingship like that of Sparta $;^{2}$ and in the yearly ceremony of the Regifugium or Flight of the King we seem to detect a trace of an annual, not a lifelong, tenure of office. The same thing may perhaps be true of the parallel change which took place at Athens when the people deprived the Medontids of their regal powers and reduced them from kings to responsible magistrates, who held office at first for life, but afterwards only for periods of ten years. ${ }^{3}$ Here, too, the limitation of the tenure of the kingship may have been merely the reinforcement of an old custom which had fallen into abeyance. At Rome, however, the attempt

I Livy, i. 34. 2 sq., i. $3^{8.1}$, i. 57.6 ; Dionysius Halicarn. Ant. Rom. iv. 64.

2 I owe to Mr. A. B. Cook the interesting suggestion that the institution of the double consulship was a revival of a double kingship.

${ }^{3}$ Pausanias, iv. 5. 10; G. Gilbert, Handbuch der griech. Staatsalterthilmer, i. ${ }^{2}$ $122 \mathrm{sq}$. 
to maintain the hereditary principle, if it was made at all, was almost immediately abandoned, and the patricians openly transferred to themselves the double kingship, which thenceforth was purely elective, and was afterwards known as the consulship. ${ }^{1}$

The history of the last king of Rome, Tarquin the Proud, leads us to surmise that the offence which he gave by his ambitious and domineering character was heightened by an attempt to shift the succession of the kingship from the female to the male line. He himself united both claims in his own person; for he had married the daughter of his predecessor, Servius Tullius, and he was the son or grandson of Tarquin the Elder, who preceded Servius Tullius on the throne. But in asserting his right to the crown, if we can trust Roman history on this point, Tarquin the Proud entirely ignored his claim through women as the son-in-law of his predecessor, and insisted only on his claim in the male line as the son or grandson of a former king. ${ }^{3}$ And he evidently intended to bequeath the kingdom to one of his sons ; for he put out of the way two of the men who, if the succession had been through women in the way I have indicated, would have been entitled to sit on the throne before his own sons, and even before himself.

1 The two supreme magistrates who replaced the kings were at first called prators. See Livy, iii. 55. 12 ; B. G. Niebuhr, History of Rome, ${ }^{3}$ i. 520 sq9.; Th. Mommsen, Romisches Staassrechs, ii. 74 sgg. That the power of the first consuls was, with the limitations indicated in the text, that of the old kings is fully recognised by Livy (ii. 1. 7 sq.).

2 It was a disputed point whether Tarquin the Proud was the son or grandson of Tarquin the Elder. See Livy, i. 46. 4 ; Dionysius Halicarn. Ant. Rom. iv. 6 sq.

3 Livy, i. 48.2 ; Dionysius Halicarn. Ant. Rcm. iv. 31 sg. and 46. 
One of these was his sister's husband, the other was her elder son. Her younger son, the famous Lucius Junius Brutus, only escaped the fate of his father and elder brother by feigning, like Hamlet, imbecility, and thus deluding his wicked uncle into the belief that he had nothing to fear from such a simpleton. ${ }^{1}$ This design of Tarquin to alter the line of succession from the female to the male side of the house may have been the last drop which filled his cup of high-handed tyranny to overflowing. At least it is a strange coincidence, if it is nothing more, that he was deposed by the man who, under a system of female kinship, was the rightful heir, and who in a sense actually sat on the throne from which he pushed his uncle. For the curule chair of the consul was little less than the king's throne under a limited tenure.

It has often been asked whether the Roman monarchy was hereditary or elective. The question implies an opposition between the two modes of succession which by no means necessarily exists. As a matter of fact in many African tribes at the present day the succession to the kingdom or chieftainship is determined by a combination of the hereditary and the elective principle; that is, the kings or chiefs are chosen by the people or a body of electors from among the members of the royal family. And as the chiefs have commonly several

${ }^{1}$ Livy, i. 56; Dionysius Halicarn. Ant. Rom. iv. 67-69, 77 ; Valerius Maximus, vii. 3. 2; Aurelius Victor, De viris illustribus, x. The murder of Brutus's father and brother is recorded by Dionysius; the other writers mention the assassination of his brother only. The resemblance between Brutus and Hamlet has been pointed out before. See F. York Powell, in Elton's translation of Saxo Grammaticus, pp. 405.410. 
wives and many children by them, the number of possible candidates may be not inconsiderable. To take a single instance out of many, we are told that " the government of the Banyai is rather peculiar, being a sort of feudal republicanism. The chief is elected, and they choose the son of the deceased chief's sister in preference to his own offspring. When dissatisfied with one candidate, they even go to a distant tribe for a successor, who is usually of the family of the late chief, a brother, or a sister's son, but never his own son or daughter." 1

Sometimes the field of choice is extended still further by a rule that the chief may or must be chosen from one of several families in a certain order. Thus among the Bangalas of the Cassange Valley in Angola the chief is elected from three families in rotation. ${ }^{2}$ And Diagara, a country bordering on Senegambia, is ruled by an absolute monarch who is chosen alternately from two families, one of whom lives in one place and the other in another. ${ }^{3}$

Among the Yorubas in western Africa the principal chief is always taken from one or more families which have the hereditary right of furnishing the community with rulers. In many cases the succession passes with established regularity from one to a second family alternately; but in one instance, apparently unique, the

1 D. Livingstone, Missionary Travels and Researches in Scuth Africa, pp. $617 \mathrm{sq}$. Many more examples are given by A. H. Post, Afrikanische Gurisprudenz (Oldenburg and Leipsic, 1887), i. 134 sqg.

2 D. Livingstone, op. cit. p. 434.

${ }^{3} \mathrm{H}$. Hecquard, Reise an die Kiste und in das Innere von West-Afrika (Leipsic, 1854), p. 104. 
right of succession to the chiefly primacy seems to be possessed by four princely families, from each of which the head chief is elected in rotation. The principle of primogeniture is not necessarily followed in the election, but the choice of the electors must always fall on one who is related to a former chief in the male line. For paternal descent alone is recognised in Yorubaland, where even the greatest chief may take to wife a woman of the lowest rank. Sometimes the choice of the ruling chief is made by divine authority, intimated to the people through the high priest of the principal god of the district. $^{1}$

Among the Igaras, on the lower Niger, the royal family is divided into four branches, each of which provides a king in turn. The capital and its district, both of which bear the name of Idah, are always occupied by the reigning branch of the royal family, while the three other branches, not being allowed to live there, retreat into the interior. Hence at the death of a king a double change takes place. On the one hand, the late reigning family, with all their dependents, have to leave the homes in which many of them have been born and brought up, and to migrate to towns in the forest, which they know only by name. On the other hand, the new reigning family comes in to the capital, and their people settle in the houses occupied by their forefathers four reigns ago. The king is generally elected by the leading men of his branch of the royal family :

ISir Willian MacGregor, "Lagos, Abeokuta, and the Alake," Fournal of the African Society, No. XII., July 1904, pp. 470 sq. 
they choose the richest and most powerful man of their number. ${ }^{1}$

Thus the mere circumstance that all the Roman kings, with the exception of the two Tarquins, appear to have belonged to different families, is not of itself conclusive against the view that heredity was one of the elements which determined the succession. The number of families from whom the king might be elected may have been large. And even if, as is possible, the electors were free to choose a king without any regard to his birth, the hereditary principle would still be maintained if, as we have seen reason to conjecture, it was essential that the chosen candidate should marry a woman of the royal house, who would generally be either the daughter or the widow of his predecessor. In this way the apparently disparate principles of unfettered election and strict heredity would be combined: the marriage of the elected king with the hereditary princess would furnish the link between the two. Under such a system, to put it otherwise, the kings are elective and the queens hereditary. This is just the converse of what happens under a system of male kinship, where the kings are hereditary and the queens elective.

In the later days of Rome it was held that the ancient custom had been for the people to elect the kings and for the senate to ratify the election. ${ }^{2}$ But

1 C. Partridge, "The Burial of the Atta of Igaraland and the 'Coronation' of his Successor," Blackwood's Magazine, September 1904, pp. 329 sq. Mr. Partridge was so good as to give me some details as to the election of the king in a letter dated 24th October 1904. He is Assistant District Commissioner in Southern Nigeria.

${ }^{2}$ Livy, i. 17 ; Cicero, De re publica, ii. 17.31 . 
we may suspect, with Mommsen, that this was no more than an inference from the mode of electing the consuls. The magistrates who, under the republic, represented the kings most closely were the dictator and the King of the Sacred Rites, and neither of these was elected by the people. Both were nominated, the dictator by the consul, and the King of the Sacred Rites by the chief pontiff. ${ }^{1}$ Accordingly it seems probable that under the monarchy the king was nominated either by his predecessor or, failing that, by an interim king (interrex) chosen from the senate. ${ }^{2}$ Now if, as we have been led to think, an essential claim to the throne was constituted by marriage with a princess of the royal house, nothing would be more natural than that the king should choose his successor, who would commonly be his son-in-law. If he had several sons-in-law and had omitted to designate the one who was to reign after him, the election would be made by his substitute, the interim king.

The personal qualities which recommended a man for a royal alliance and succession to the throne would naturally vary according to the popular ideas of the time and the personal character of the king or his substitute; but it is reasonable to suppose that among them in early society physical strength and beauty would hold a prominent place. We have seen that in

1 As to the nomination of the King of the Sacred Rites see Livy, xl. 42 ; Dionysius Halicarn. Ant. Rom. v. 1. 4. The latter writer says that the augurs cooperated with the pontiff in the nomination.

2 Th. Mommsen, Römisches Staatsrecht, ii. ${ }^{3}$ 6-8 ; A. H. J. Greenidge, Roman Public Life, pp. 45 sq9. Mr. Greenidge thinks that the king was regularly nominated by his predecessor and only occasionally by an interim king. Mommsen holds that he was always nominated by the latter. 
Ashantee the husbands of the princesses must always be men of fine presence, because they are to be the fathers of future kings. Among the Ethiopians in antiquity, as among the Ashantees and many other African tribes to this day, the crown passed in the female line to the son of the king's sister, but if there was no such heir they chose the handsomest and most valiant man to reign over them. ${ }^{1}$

We are told that the Gordioi elected the fattest man to the kingship, ${ }^{2}$ nor is this incredible when we remember that in Africa corpulence is still regarded as a great distinction and beauty, and that both the chiefs and their wives are sometimes so fat that they can hardly walk. Thus among the Caffres, chiefs and rich men attain to an enormous bulk, and the queens fatten themselves on beef and porridge, of which they partake freely in the intervals of slumber. To be fat is with them a mark of wealth and therefore of high rank : common folk cannot afford to eat and drink and lounge as much as they would like to do. ${ }^{3}$

The Syrakoi in antiquity are reported to have bestowed the crown on the tallest man or on the man with the longest head, in the literal, not the figurative, sense of the words." They seem to have been a Sarmatian people to the north of the Caucasus, ${ }^{5}$ and are

1 Nicolaus Damascenus, in Stobæus, Florilegium, xliv. 41 (Fragmenta Hissoricorwn Graecorum, ed. C. Muller, iii. 463). Other writers say simply that the tallest, strongest, or handsomest man was chosen king. See Hcrodotus, iii. 20; Aristotle, Polisics, iv. 4 ; Athenzus, xii. 20, p. 566 c.

2 Zenobius, Cens. v. 25.

3 J. Shooter, The Kafirs of Natal (London, 1857 ), pp. 4 sq. Compare D. Livingstone, Missionary Travels and Researches in South Africa, p. 186.

4 Zenobius, Cent. v. 25.

Strabo, xi. 2. x. 
probably the same with the long-headed people described by Hippocrates, who says that among them the men with the longest heads were esteemed the noblest, and that they applied bandages and other instruments to the heads of their children in infancy for the sake of moulding them into the shape which they admired. ${ }^{1}$ Such reports are probably by no means fabulous, for among the Monbuttu or Mang-bettou of central Africa down to this day "when the children of chiefs are young, string is wound round their heads, which are gradually compressed into a shape that will allow of the longest head-dress. The skull thus treated in childhood takes the appearance of an elongated egg." 2 Similarly some of the Indian tribes on the north-west coast of America artificially mould the heads of their children into the shape of a wedge or sugar-loaf by compressing them between boards : some of them regard such heads as a personal beauty, others as a mark of high birth. ${ }^{3}$

Sometimes apparently the right to the hand of the princess and to the throne has been determined by an athletic contest. The Alitemnian Libyans awarded the kingdom to the fleetest runner. ${ }^{4}$ According to tradition the earliest games at Olympia were held by Endymion, who set his sons to run a race for the

1 Hippocrates, De acre locis et aquis (vol. i. pp. 550 sq., ed. Kühn).

2 Captain Guy Burrows, The Land of the Pigmies (London, 1898), p. 95.

${ }^{3}$ Lewis and Clark, Expedition to the Sources of the Missouri, ch. 23, vol. ii. 327 sq. (London, 1905); D. W. Harmon, quoted by Rev. J. Morse, Report to the Secretary of $W$ ar of the United States on Indian Affairs (Newhaven, 1822), Appendix, P. 346; H. H. Schoolcraft, Indian Tribes, ii. 325 sq.; R. C. Mayne, Four Years in British Columbia, p. 277 ; G. M. Sproat, Scenes and Studies of Savage Life, pp. 28-30; H. H. Bancroft, Native Races of the Pacific States, i. 180.

4 Nicolaus Damascenus, loc. cit. 
kingdom. His tomb was said to be at the point of the race-course from which the runners started. ${ }^{1}$ The famous story of Pelops and Hippodamia is perhaps only another version of the legend that the first races at Olympia were run for no less a prize than the crown. Other traditions were current in antiquity of princesses who were offered in marriage to the fleetest runner and won by the victor in the race. Thus Icarius at Sparta set the wooers of his daughter Penelope to run a race: Ulysses won and wedded her. His father-in-law is said to have tried to induce him to take up his abode in Sparta; which seems to show that if Ulysses had accepted the invitation he would have inherited the kingdom through his wife. ${ }^{2}$ So, too, the Libyan king Antæus placed his beautiful daughter Barce at the end of the race-course : her many noble suitors, both Libyans and foreigners, ran to her as the goal, and Alcidamus, who touched her first, gained her in marriage. ${ }^{3}$ Danaus, also, at Argos is said to have stationed his daughters at the goal, and the runner who reached them first had first choice of a wife. ${ }^{4} \quad$ These traditions may very well reflect a real custom of racing for a bride, for such a custom appears to have prevailed among various peoples, though in practice it has commonly degenerated into a mere form or pretence. $^{5}$

1 Pausanias, v. 1. 4, vi. 20. 9.

2 Pausanias, iii. 12. 1, iii. 20. 10 sq.

3 Pindar, Pytb. ix. 181-220, with the Scholia.

+ Pindar, Pysh. ix. 195 sq9.; Pausanias, iii. 12. 2.

5 J. F. M'Lennan, Seudies in Anciens History (London, 1886), pp. 15 sq., 181. 184: More evidence will be adduced in the third edition of The Golden Bough. 
But the contests for a bride may be designed to try the skill, strength, and courage of the suitors as well as their horsemanship and speed of foot. In the great Indian epic of the Mahabharata it is related that the hand of the lovely princess Draupadi, daughter of the king of the Panchalas, was only to be won by him who could bend a certain mighty bow, and shoot five arrows through a revolving wheel, so as to hit the target beyond. After many wooers had essayed the task in vain, the disguised Arjun was successful, and carried off the princess to be his wife. ${ }^{1}$ This was an instance of the ancient Indian practice of the Svayamvara, in accordance with which a maiden of high rank either chose her husband from among her assembled suitors or was offered as the prize to the conqueror in a trial of skill. The custom was occasionally observed among the Rajputs down to a late time. ${ }^{2}$ In the Niebelungenlied the fair Brunhild, queen of Iceland, was only to be won in marriage by him who could beat her in three trials of strength, and the unsuccessful wooers forfeited their heads. Many had thus perished, but at last Gunther, king of the Burgundians, vanquished and married her. ${ }^{3}$ It is said that Sithon, king of the Odomanti in Thrace, had a lovely daughter Pallene, and that many

1 Mahabharata, condensed into English by Romesch Dutt (London, 1898), pp. 15 sqq.; J. C. Oman, The Great Indian Epics, pp. 109 sqq.

2 J. D. Mayne, A Treatise on Hindu Law and Usage ${ }^{3}$ (Madras and London, 1883), p. $5^{6}$; The Vikramânkadevacharita, edited by G. Bühler (Bombay, 1875), pp. 38-40; A. Holtzmann, Das Mahäbharata und seine Theile, i. (Kiel, 1895), pp. 21 sq. ; J. Jolly, Recht und Sitte, pp. 50 sq. (in G. Bühler's Grundriss der Indo-Arischen Philologie).

3 The Lay of the Niebelungs, translated by Alice Horton (London, 1898), Adventures VI. and VII. 
men came courting her from far and near. But her father said that he who would wed his daughter must first fight himself and pay with his life the penalty of defeat. Thus he slew many young men. But when he was grown old and his strength had failed, he set two of the wooers to fight each other for the kingdom and the hand of the princess. One of them slew the other and married the king's daughter. ${ }^{1}$

Thus it appears that the right to marry a girl, and especially a princess, has often been conferred as a prize in an athletic contest. There would be no reason, therefore, for surprise if the Roman kings, before bestowing their daughters in marriage, should have resorted to this ancient mode of testing the personal qualities of their future sons-in-law and successors. If my theory is correct, the Roman king and queen personated Jupiter and his divine consort, and in the character of these divinities went through the annual ceremony of a sacred marriage for the purpose of causing the crops to grow and men and cattle to be fruitful and multiply. Thus they did what in more northern lands we may suppose the King and Queen of May were believed to do in days of old. Now we have seen in a former lecture ${ }^{2}$ that the right to play the part of the King of May and to mate with the Queen of May has sometimes been determined by an athletic contest, particularly by a race. This contest may have

1 Parthenius, Narrat. Amat, vi. This passage was pointed out to me by Mr. A. B. Cook, who has himself discussed the contest for the kingship. See his article, "The European Sky-god," Folk-lore, xv. (1904), pp. 376 sqg.

2 Above, pp. 164 sq. 
been a relic of an old marriage custom of the sort we have examined, a custom designed to test the fitness of a candidate for matrimony. Such a test might reasonably be applied with peculiar rigour to the king in order to ensure that no personal defect should incapacitate him for the performance of those sacred rites and ceremonies on which, even more than on the despatch of his civil and military duties, the safety and prosperity of the community were believed to depend. A relic of that test perhaps survived at Rome in the ceremony known as the Regifugium or Flight of the King, which continued to be annually observed down to imperial times. On the twenty-fourth day of February a sacrifice used to be offered in the Comitium, and when it was over the King of the Sacred Rites fled from the Forum. ${ }^{1}$ I conjecture that the Flight of the King was originally a race for an annual kingship, which may have been awarded as a prize to the fleetest runner. At the end of the year the king might run again for a second term of office; and so on, until he was defeated and deposed or perhaps slain. In time a man of masterful character might succeed in seating himself permanently on the throne and reducing the annual race or flight to the empty form which it seems always to have been within historical times.

1 Ovid, Fasti, ii. 685 sqq.; Plutarch, 2uaest. Rom. 63; J. Marquardt, Romiscbe Staatsverwaltung, iii. ${ }^{2} 323$ sq.; W. Warde Fowler, Roman Festivals of the Period of the Republic, pp. 327 sqq. 


\section{LECTURE IX}

The King's Flight at Rome in relation to the Saturnalia-Human representatives of Saturn killed at the Saturnalia-Violent deaths of Roman kings - Saturn and Jupiter-Summary of conclusions as to the King of the Wood at Nemi-He represented Jupiter or Janus and mated with Diana-Janus or Dianus and Diana the equivalents of Jupiter and JunoReasons for putting the divine king to death-The King of Calicut an Indian parallel to the King of the Wood at Nemi.

IN the last lecture I gave some reasons for thinking that at Rome the old kings belonged to the indigenous and conquered race, and that the right to the throne was transmitted through women, being enjoyed by the man who married a princess of the royal house after proving his fitness for office in an athletic contest of strength or speed. Of that contest I conjectured that the ceremony known as the Regifugium or Flight of the King may have been a survival. If my theory is correct, the yearly Flight of the King is a relic of a time when the kingship was an annual office awarded, along with the hand of a princess, to the victorious athlete or gladiator, who thereafter figured along with his bride as a god and goddess at a sacred marriage designed to ensure the fertility of the earth by homœopathic magic. 
Accepting this theory as a provisional hypothesis, we have still to ask whether or not the Flight of the King was immediately connected in point of time with the ceremony of the Sacred Marriage. As to this, it is to be observed that the date of the King's Flight, namely, the twenty-fourth of February, was within four days of the close of the old Roman year, which ended with February long before it ended with December. Now, in later times, when the year began with January, the festival of the Saturnalia was held in December, from the seventeenth to the twenty-third of the month. ${ }^{1}$ But the analogy of similar festivals elsewhere makes it probable that the Saturnalia always fell at or near the end of the year; so that when February was the last month of the calendar, the Saturnalia might be expected to be celebrated in it rather than in December. On this theory the date of the Saturnalia in the old Roman calendar ought to be the seventeenth to the twentythird of February. But the Flight of the King fell on the twenty-fourth of February, that is on the very day after the Saturnalia, if my hypothesis as to the original date of that festival is correct. This accords perfectly with all that we know of similar festivals. For their outstanding features appear to have been, first, a general license accorded to the whole population, including slaves as well as freemen; second, the temporary reign of a sacred King or Lord of Misrule; third, the marriage of the merry monarch to a woman who

1 On the Saturnalia, see L. Preller, Rümische Mythologie, ${ }^{8}$ ii. I 5 sqq.; Dezobry, Rome au siècle d'Auguste, ${ }^{3}$ iii. 143 sqq. 
personated a goddess; and, fourth, the deposition or violent death of the king. ${ }^{1}$ If the analogy of these festivals held good for Rome, we should accordingly have to suppose that the King's Flight at the end of the Saturnalia was a substitute for his deposition or death ; in other words, that instead of being killed out of hand he was allowed to run for his life, and that if he showed a clean pair of heels to his pursuers and competitors he was permitted to live and reign another year.

Now this theory in all its details receives most remarkable confirmation from an ancient account of the Saturnalia which was discovered and published a few years ago by Professor F. Cumont of Ghent. From that account we learn that down to the beginning of the fourth century of our era, that is, down nearly to the establishment of Christianity by Constantine, the Roman soldiers stationed on the Danube were wont to celebrate the Saturnalia in a barbarous fashion which must certainly have dated from a very remote antiquity. Thirty days before the festival they chose by lot from among themselves a young and handsome man, who was dressed in royal robes to resemble the god Saturn. In that character he was allowed to indulge all his passions to the fullest extent; but when his brief reign of thirty days was over, and the festival of Saturn was come, he had' to cut his own throat on the altar of the god he personated. ${ }^{2}$

1 The Golden Bough, ${ }^{2}$ iii. ${ }_{13} 8$ sgg.

2 F. Cumont, "Les Actes de S. Dasius," Analecsa Bollandiara, xvi. (1897), pp. 5-16. See further Messrs. Parmentier and Cumont, "Le roi des Saturnales," Revue de Plilologie, xxi. (1897), pp. 143-153. 
In this very notable custom we have not merely the personation of the god Saturn by a man and the violent death of the man-god; we have also a clear trace of the Sacred Marriage in the licence accorded to the human representative of the deity, a licence which, on my theory, is strictly analogous to the old orgies of May Day and other similar festivals. Observe that Saturn was the god of the seed, and the Saturnalia the festival of sowing. ${ }^{1}$ How an Italian festival of sowing could fall in midwinter has always been a puzzle. But the difficulty vanishes as soon as we perceive that in the old calendar the date of the celebration must have been not December but February; for in Italy the month of February is, along with March, the great season of the spring sowing. ${ }^{2}$ Nothing therefore could be more natural than that the god of the seed should hold his festival at that time of the year. And on the principles of homœopathic magic nothing could be more natural than that at the season of sowing the marriage of the powers of vegetation should be simulated by the marriage of human beings for the purpose of sympathetically quickening the growth of the seed. ${ }^{3}$ In short, no time could be more suitable for the celebration of the Sacred Marriage. At all events, the view that the King's Flight on the twenty-fourth of

J Varro, De lingua Latina, v. 64 ; Festus, s.v. "Opima spolia," p. 186, ed. C. O. Moller ; Augustine, $D_{e}$ civitate $D e i$, vi. chapter 8 , vii. chapters $2,3,13,15,18$, 19 ; Tertullian, Ad Nationes, ii. 12 ; L. Preller, Romische Mythologie, ${ }^{3}$ ii. I1.

2 Palladius, De re rustica, books iii. and iv. passim.

${ }^{3}$ See The Golden Bough, ${ }^{2}$ ii. 204 sqq. 
February was a mitigation of an older custom of putting him to death is strongly confirmed by the evidence that in the old calendar the ceremony followed immediately after the Saturnalia, and that the King of the Saturnalia, as he was called, had formerly to cut his own throat in public at the end of his brief reign.

If $\mathrm{I}$ am right in supposing that in very early times the old Latin kings personated a god and were regularly put to death in that character, a new light is thrown on the mysterious or violent ends to which so many of the Roman monarchs are said to have come. Too much stress should not, however, be laid on such legends, for, in a turbulent state of society, kings, like commoners, are apt to be knocked on the head for much sounder reasons than a claim to divinity. Still it is worth while to note that Romulus is said to have vanished mysteriously or to have been cut to pieces by the patricians whom he had offended $;^{1}$ and further, that the seventh of July, the day on which he perished, was a festival which bore some resemblance to the Saturnalia. For on that day the female slaves were allowed to take certain remarkable liberties. They dressed up as free women in the attire of matrons and maids, and in this guise they went forth from the city, scoffed and jeered at all whom they met, and engaged among themselves in a fight, striking and throwing stones at each other. Moreover, they feasted under a wild fig tree, made use of a rod cut from the tree,

\footnotetext{
1 Livy, i. 16; Dionysius Halicarn. Ant. Rom. ii. 56 ; Plutarch, Romulus, 27 ; Florus, i. 1. $16 \mathrm{sq.} \mathrm{Sec} \mathrm{above,} \mathrm{p.} 205$.
} 
perhaps to beat each other with, and offered the milky juice of the tree in sacrifice to Juno Caprotina, whose name appears to mean either the goddess of the goat (caper) or the goddess of the wild fig tree; for the Romans called a wild fig tree a goat-fig (caprificus). Hence the day was called the Nonae Caprotinae, after the animal or the tree. The festival was not peculiar to Rome, but was held by women throughout Latium. ${ }^{1}$ It can hardly be dissociated from a custom which was observed by ancient husbandmen at this season. They sought to fertilise the fig trees or to ripen the figs by hanging among the boughs of the trees strings of fruit taken from a wild fig tree. The practice appears to be very old. It has been employed in Greece both in ancient and modern times, and Roman writers often refer to it. Palladius recommends the solstice in June as the best time for the operation; Columella prefers July. ${ }^{2} \quad$ The wild fig tree is a male, and the cultivated

1 Varro, De lingua Latina, vi. 18; Plutarch, Romulus, 29; id., Camillus, 33 ; Macrobius, Saturn. i. 11. 36-40.

2 Aristotle, Histor. Anim. v. 32, p. 557 b, ed. Bekker; Theophrastus, Hist. Plant. ii. 8 ; id., De causis Plantarum, ii. 9 ; Plutarch, Quaest. Conviv. vii. 2. 2 ; Pliny, Nat. Hist. xv. 79-81, xvi. 114, xvii. 256 ; Palladius, iv. 10. 28 , vii. 5. 2 ; Columella, xi. 2. 56 ; Geoponica, iii. 6, x. 48. As to the practice in modern Greece see P. de Tournefort, Relation d'un voyage du Levant (Amsterdam, 1718), i. 130 . As to the process and its relation to the domestication and spread of the fig tree, see Graf zu Solms-Laubach, "Die Herkunft, Domestication und Verbreitung des gewohnlichen Feigenbaums" (Ficus Carica, L.), Abhandlungen der königlichen Gesellschaft der Wissenschaften zu Göttingen, xxviii. (1882), pp. 1-106. This last writer thinks that the operation was not practised by Italian husbandmen, because it is not mentioned by Cato and Varro. But their silence can hardly outweigh the express mention and recommendation of it by Palladius and Columella. Theophrastus, it is true, says that the process was not in use in Italy (Hist. Plantarum, ii. 8. 1), but he can scarcely have had exact information on the subject. Caprificatio, as it is called, is still employed by the Neapolitan peasantry, though it seems to be unknown in northern Italy. It is practised in Morocco on Midsummer Day, bunches of figs from the male trees being then hung in straw on the female 
fig tree is a female, and the fertilisation is effected by insects which are engendered in the fruit of the male tree and convey the pollen to the blossom of the female. ${ }^{1}$ Thus the placing of wild figs, laden with pollen and insects, among the boughs of the cultivated fig is, like the artificial fertilisation of the date-palm, a real marriage of the trees; and it may well have been regarded as such by the peasants of antiquity long before the true theory of the process was discovered.

Now the fig is an important article of diet in countries bordering on the Mediterranean. When Sandanis the Lydian attempted to dissuade Crœsus from marching against the Persians, he represented to him that there was nothing to be gained by conquering the inhabitants of a barren country who neither drank wine nor ate figs. ${ }^{2}$ An Arab commentator on the Coran observes that "God swears by these two trees, the fig and the olive, because among

trees (Budgett Meakin, The Mcors (London, 1902), p. 258). The Latin name "goat-fig" (caprificus) applied to the wild fig tree may well be derived from the notion that the tree is a male who mates with the female tree. Similarly, the Messenians called the tree simply " he-goat" ( $\tau$ páros). See Pausanias, iv. 20. 1-3.

${ }^{1}$ A. Engler, in V. Hehn's Kulturpflanzen und Hausthiere ${ }^{7}$ (Berlin, 1902), p. 99. Compare Graf zu Solms-Laubach, op. cit. Professor H. Marshall Ward has furnished me with an exact description of the process, which will be printed in the third edition of The Golden Bough. The ancients were well aware of the production of the insects in the wild fig tree and their transference to the cultivated fig tree. Sometimes, instead of fertilising the trees by hand, they contented themselves with planting wild fig trees near cultivated fig trees, so that the fertilisation was cffected by the wind, which blew the insects from the male to the female trees. See Aristotie, l.c. ; Theophrastus, De causis Plantarum, ii. 9; Pliny, Nat. Hist. xv. 79.81 ; Palladius, iv. 10.28. The suggestion that the festival of the seventh of July was connected with this horticultural operation is due to L. Preller (Romische Myshologie, ${ }^{3}$ i. 287).

2 Herodotus, i. 71 . 
fruit trees they surpass all the rest. They relate that a basket of figs was offered to the prophet Mohammed, and when he had eaten one he bade his comrades do the same, saying, 'Truly, if I were to say that any fruit had come down from Paradise, I would say it of the fig." "I Hence it would be natural that a process supposed, not without reason, to be essential to the ripening of a favourite fruit should be the occasion of a popular festival. We may surmise that the licence allowed to slave women on this day formed part of an ancient Saturnalia which was supposed to fertilise the figs by homœopathic magic.

The association of the death of Romulus with the festival of the wild fig tree can hardly be accidental, especially as he and his twin-brother were said to have been suckled by the she-wolf under a fig tree, which was always shown as one of the sacred objects of the city and received offerings of milk down to late times. ${ }^{2}$ The clue to the association is probably furnished by the old belief that the king is responsible for the fruits of the earth. We may conjecture that in like manner the Roman king was expected to make the fig trees blossom and bear figs, and that in order to do so he went through a form of Sacred Marriage on the July

1 Zamachschar, cited by Graf zu Solms-Laubach, op. cit. p. 82. For more evidence as to the fig in antiquity see V. Hehn, Kulturpfianzen und Hausthiere, pp. 94 sqq.

2 Varro, De lingua Latina, v. 54 ; Livy, i. 4. 5 ; Ovid, Fasti, ii. 4 I 1 sq.; Pliny, Nat. Hist. xv. 77 ; Festus, p. 270, ed. C. O. Muller; Tacitus, Annals, xiii. 58 ; Servius, on Virgil, Aen. viii. 90; Plutarch, Romulus, 4; id., Quaest. Rom. 57 ; Dionysius Halicarn. Ant. Rom. iii. 71. 5. All the Roman writers speak of the tree as a cultivated fig (ficus), not a wild fig (caprificus), and Dionysius agrees with them.

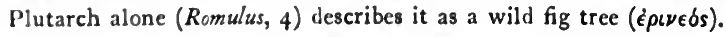


day when the husbandmen resorted to a more efficacious means of producing the same result. The ceremony of the Sacred Marriage need not have been restricted to a single day in the year. It may well have been repeated for many different crops and fruits. If the queen of Athens was annually married to the god of the vine, why should not the king of Rome have wedded the goddess of the fig?

We have still to ask, Why should the king's wedding-day be also the day of his death? The problem cannot be solved till the wider question has been answered, Why has it been customary to slay the divine king or human god? That question I shall endeavour briefly to answer a little later on. Here I will only say that elsewhere the marriage of the sacred king or divine man has been often followed at a brief interval by his violent death.

Another Roman king who perished by violence was Tatius, the Sabine colleague of Romulus. It is said that he was at Lavinium offering a public sacrifice to the ancestral gods, when some men to whom he had given umbrage despatched him with the sacrificial knives and spits which they had snatched from the altar. ${ }^{1}$ The occasion and the manner of his death suggest that the slaughter may have been a sacrifice rather than an assassination. Tullus Hostilius was commonly said to have been killed by lightning, but many held that he was murdered at the instigation of his successor

\footnotetext{
${ }^{1}$ Livy, i. 34. I sq. ; Dionysius Halicarn. Ant. Rom. ii. 52. 3 ; Plutarch, Romulus, 23.
} 
Ancus Marcius. ${ }^{1}$ Speaking of Numa, Plutarch observes that "his fame was enhanced by the fortunes of the later kings. For of the five who reigned after him the last was deposed and ended his life in exile; and of the remaining four not one died a natural death, for three of them were assassinated and Tullus Hostilius was consumed by thunderbolts." 2 This implies that King Ancus Marcius, as well as Tarquin the Elder and Servius Tullius, perished by the hand of an assassin. No other ancient historian, so far as I know, records this of Ancus Marcius, though one of them says that the king "was carried off by an untimely death." 3 Tarquin the Elder was slain by two murderers whom the sons of his predecessor, Ancus Marcius, had hired to do the deed. ${ }^{4}$ Lastly, Servius Tullius came by his end in circumstances which, as Mr. A. B. Cook was the first to point out, recall the combat for the priesthood of Diana at Nemi. $\mathrm{He}$ was attacked by his successor and killed by his orders, though not by his hand. Moreover, he lived among the oak groves of the Esquiline Hill at the head of the Slope of Virbius, and it was here, beside a sanctuary of Diana, that he was slain. ${ }^{5}$

These legends of the violent ends of the Roman

1 Dionysius Halicarn. Ant. Rom. iii. 35 ; Zonaras, Annales, vii. 6. As to his reported death by lightning, see above, pp. 204 sq.

2 Plutarch, Numa, 22. I have pruned the luxuriant periods in which Plutarch dwells, with edifying unction, on the righteous visitation of God which overtook that early agnostic Servius Tullius.

3 Aurelius Vietor, De viris illustribus, v. 5.

4 Livy, i. 40 ; Dionysius Halicarn. Ant. Rom. iii. 73.

${ }^{5}$ Livy, i. $4^{8}$; Dionysius Halicarn. Ant. Rom. iv. $3^{8}$ sq.; Solinus, i. 25. See Mr. A. B. Cook, in Classical Reviero, xvi. (1902), p. 380 , note 3 . 
kings suggest that the contest by which they gained the crown may sometimes have been a mortal combat rather than a race. It would not be surprising if among the early Latins the claim to the kingdom should often have been settled by single combat; for down to historical times their kinsfolk the Umbrians regularly submitted their private disputes to the ordeal of battle, and he who cut his adversary's throat was thought thereby to have proved the justice of his cause beyond the reach of cavil. ${ }^{1}$

A parallel to what I conceive to have been the rule of the old Latin kingship is furnished by a West African custom of to-day. When the king of the northern province of Congo has been elected, he has to take his stand at a large tree near the entrance to a sacred grove. Here, encouraged by one of his ministers, he must fight all rivals who present themselves to dispute his right to the throne. ${ }^{2}$ In England down to the nineteenth century we had a relic of a similar custom in the champion who at the coronation of a king or queen threw down his glove and challenged to mortal combat all who disputed the king's or queen's right to the crown. I believe the practice was discontinued for the first time at the coronation of

\footnotetext{
1 Nicolaus Damascenus, in Stobrus, Florilegium, x. 70 ; Fragmenta Historicorum Graecorum, ed. C. Maller, iii. 457. Compare H. Jordan, Die Konige im alten Italien (Berlin, 1887), pp. 44 sq. In this his last work Jordan argues that the Umbrian practice, combined with the rule of the Arician priesthood, throws light on the existence and nature of the kingship among the ancient Latins. I am happy to agree with so learned and judicious a scholar.

2 From an unpublished manuscript of Mr. R. E. Dennet in the possession of the Folk-lore Society. I have to thank Mr. N. W. Thomas for his kindness in copying out and sending me the passage, of which I have given the substance in the text.
} 
his present Majesty. So tenacious is royalty of forms that may be traced back to a barbarous antiquity. Pepys in his Diary describes as an eyewitness the ceremony of the challenge at the coronation of Charles the Second. He says, "And many fine ceremonies there was of the heralds leading up people before him, and bowing ; and my Lord of Albemarle's going to the kitchen and eating a bit of the first dish that was to go to the King's table. But, above all, was these three Lords, Northumberland and Suffolk, and the Duke of Ormond, coming before the courses on horseback and staying so all dinner-time, and at last bringing up (Dymock) the King's Champion, all in armour on horseback, with his speare and targett carried before him. And a Herald proclaims " That if any dare deny Charles Stewart to be lawful King of England, here was a Champion that would fight with him'; and with these words, the Champion flings down his gauntlet, and all this he do three times in his going up towards the King's table. To which when he is come, the King drinks to him, and then sends him the cup, which is of gold, and he drinks it off, and then rides back again with the cup in his hand." 1

In the foregoing inquiry we have seen reason to suppose that the Roman kings personated not only Jupiter, the god of the oak, but also Saturn, the god of the seed. The question naturally arises, Did they do so simultaneously or successively? In other words, Did

1 Memoirs of Samuel Pepys, edited by Richard, Lord Braybrooke, Second Edition (London, 1828), i. 193 sq. (under April 23rd, 1661). 
the same king represent Jupiter at one time of the year and Saturn at another? or did the kings of a certain period or a certain dynasty represent Jupiter only, while the kings of another period or another dynasty personated Saturn alone? The documents at our disposal do not allow us to answer these questions definitely. But tradition certainly points to the conclusion that in Latium and perhaps in Italy generally Saturn was an older god than Jupiter, just as in Greece Cronus appears to have preceded Zeus. Saturn and Cronus were perhaps the gods of an indigenous and agricultural people; while Zeus and Jupiter were the deities of a ruder invading race, who swarmed down into the fertile lands of Greece and Italy from the forests of central Europe, bringing their sylvan divinities with them, and displacing the ancient native god of the seed by their own imported god of the oak and the thunder. If that was so, we may suppose that before the incursion of these northern barbarians the old kings of Greece and Italy personated Cronus and Saturn, but that after the conquest they or their successors adopted the gods of the conquerors and played the parts of Zeus and Jupiter. However, as I have said, the evidence is too scanty to allow of a positive decision in a matter of so much obscurity.

This must conclude our examination of the sacred character of the early Latin kings in general.

I propose now to recapitulate the conclusions to which the inquiry has thus far led us, and drawing 
together the scattered rays of light to turn them on the dark figure of the priest of Nemi.

We have found that at an early stage of society men, ignorant of the secret processes of nature and of the narrow limits within which it is in our power to control and direct them, have commonly arrogated to themselves functions which in the present state of knowledge we should deem superhuman or divine. The illusion has been fostered and maintained by the same causes which begot it, namely, the marvellous order and uniformity with which Nature conducts her operations, the wheels of her great machine revolving with a smoothness and precision which enable the patient observer to anticipate in general the season, if not the very hour, when they will bring round the fulfilment of his hopes or the accomplishment of his fears. The regularly recurring events of this great cycle, or rather series of cycles, soon stamp themselves even on the dull mind of the savage. He foresees them, and foreseeing them mistakes the desired recurrence for an effect of his own will, and the dreaded recurrence for an effect of the will of his enemies. Thus the springs which set the vast machine in motion, though they lie far beyond our ken, shrouded in a mystery which we can never hope to penetrate, appear to ignorant man to lie within his reach : he fancies he can touch them and so work by magic art all manner of good to himself and evil to his foes. In time the fallacy of this belief becomes apparent to him : he discovers that there are things he cannot do, pleasures 
which he is unable of himself to procure, pains which even the most potent magician is powerless to avoid. The unattainable good, the inevitable ill, are now ascribed by him to the action of invisible powers, whose favour is joy and life, whose anger is misery and death. Thus magic tends to be displaced by religion, and the sorcerer by the priest. At this stage of thought the ultimate causes of things are conceived to be personal beings, many in number and often discordant in character, who partake of the nature and even of the frailty of man, though their might is greater than his, and their life far exceeds the span of his ephemeral existence. Their sharply marked individualities, their clear-cut outlines have not yet begun, under the powerful solvent of philosophy, to melt and coalesce into that single unknown substratum of phenomena, which, according to the qualities with which our imagination invests it, goes by one or other of the high-sounding names which the wit of man has devised to hide his ignorance. Accordingly, so long as men look on their gods as beings akin to themselves and not raised to an unapproachable height above them, they believe it to be possible for those of their number who surpass their fellows to attain to divine rank after death, or even in life. Incarnate human deities of this latter sort may be said to halt midway between the age of magic and the age of religion. If they bear the names and display the pomp of deities, the powers which they are supposed to wield are commonly those of their predecessor the magician. Like him, they are expected to guard their 
people against hostile enchantments, to heal them in sickness, to bless them with offspring, and to provide them with an abundant supply of food by regulating the weather and performing the other ceremonies which are deemed necessary to ensure the fertility of the earth and the multiplication of animals. Men who are credited with powers so lofty and far-reaching naturally hold the highest place in the land, and while the rift between the spiritual and the temporal spheres has not yet deepened too far, they are supreme in civil as well as religious matters : in a word, they are kings as well as gods. Thus the divinity which hedges a king has its roots deep down in human history, and long ages pass before these are sapped by a profounder view of nature and of man.

In the classical period of Greek and Latin antiquity the reign of kings was for the most part a thing of the past ; yet the stories of their lineage, titles, and pretensions suffice to prove that they too claimed to rule by divine right and to exercise superhuman powers. Hence we may without undue temerity assume that the King of the Wood at Nemi, though shorn in later times of his glory and fallen on evil days, represented a long line of sacred kings who had once received not only the homage but the adoration of their subjects in return for the manifold blessings which they were supposed to dispense. What little we know of the functions of Diana in the Arician grove seems to prove that she was here conceived as a goddess of fertility, and particularly as a divinity of childbirth. It is reasonable therefore to 
suppose that in the discharge of these important duties she was assisted by her priest, the two figuring as King and Queen of the Wood in a solemn marriage which was intended to make the earth gay with the blossoms of spring and the fruits of autumn, and to gladden the hearts of men and women with healthful offspring.

If the priest of Nemi posed not merely as a king, but as a god of the grove, we have still to ask, What deity in particular did he personate? The answer of antiquity is that he represented Virbius, the consort or lover of Diana. But this does not help us much, for of Virbius we know little more than the name. A clue to the mystery is perhaps supplied by the vestal fire which burned in the grove. For the perpetual holy fires of the Aryans appear to have been commonly kindled and fed with oak wood, ${ }^{1}$ and we have seen that in Rome itself, not many miles from Nemi, the fuel of the vestal fire consisted of oaken sticks or logs, which in early days the holy virgins probably gathered or cut in the coppices of oak that once covered the Seven Hills. But the ritual of the various Latin towns appears to have been marked by great uniformity; hence it is reasonable to conclude that wherever in Latium a vestal fire was maintained, it was fed, as at Rome, with wood of the sacred oak. If this was so at Nemi, it becomes probable that the hallowed grove there consisted of an oak wood, and that therefore the tree which the King of the Wood

1 See The Golden Bough, ${ }^{2}$ iii. 347-349, where, however, the statement as to the universal use of oak wood in kindling the need-fire is too absolute, exceptions having since come to my knowledge. These will be noticed in the third edition of The Golden Bough. 
had to guard at the peril of his life was itself an oak. Now the oak was the sacred tree of Jupiter, the supreme god of the Latins. Hence it follows that the King of the Wood, whose life was bound up in a fashion with an oak, personated no less a deity than Jupiter himself. At least the evidence, slight as it is, seems to point to this conclusion. The old Alban dynasty of the Silvii or Woods, with their crown of oak leaves, appears to have aped the style and emulated the powers of Latian Jupiter, who dwelt on the top of the Alban Mount. It is not impossible that, as Mr. A. B. Cook has suggested, the King of the Wood, who guarded the sacred oak a little lower down the mountain, was the lawful successor and representative of this ancient line of the Silvii or Woods. ${ }^{1}$ At all events, if I am right in supposing that he passed for a human Jupiter, it would appear that Virbius, with whom legend identified him, was nothing but a local form of Jupiter, considered perhaps in his original aspect as a god of the greenwood.

The conclusion that the priestly kings of Nemi were regarded as a series of human Jupiters, who represented the great god on earth, and came, one after the other, to a violent end in that capacity, is singularly confirmed by a passage of Plautus. In the Casina of that dramatist an old man promises to protect a slave against the anger of the rest of his family. "I'll be your Jupiter," says he, "and so long as I am propitious, you need not care a straw for these lesser gods." " That's

1 A. B. Cook, "Zeus, Jupiter, and the Oak," Classical Revierv, xviii. (1904), pp. $3^{6} 3 \mathrm{sq}$. 
all nonsense," retorts the slave, " as if you did not know how human Jupiters die a sudden death. When you are a dead Jupiter and your kingdom has passed to others, who will there be to protect me ?" I Here the slave alludes, as a matter of common notoriety, to certain human Jupiters who died sudden deaths and whose kingdom passed to others. Now, who were these mortal Jupiters? If they were the priests of Nemi personating the great god, the allusion would be understood by every one, and would be particularly apt in the mouth of a slave, himself a member of the class from which these human Jupiters were drawn. If the allusion was not to them, it remains, as far as I know, inexplicable. I need hardly point out how exactly a dynasty of mortal Jupiters would fit on to an older dynasty of mortal Saturns, if at Nemi, as elsewhere perhaps in Latium, the earliest kings personated the god of the seed and were put to death in that character at the Saturnalia or festival of sowing long before their successors lived and died as gods of the oak.

The hypothesis that in later times at all events the King of the Wood played the part of the oak god Jupiter is confirmed by an examination of his divine partner Diana. For two distinct lines of argument converge to show that if Diana was a queen of the woods in general, she was at Nemi a goddess of the oak in particular. In the first place, she bore the title of Vesta, and as such presided over a perpetual fire, which

1 Plautus, Casina, ii. 5.23-29. I have to thank my friend Mr. A. B. Cook for calling my attention to this important passage. 
we have seen reason to believe was fed with oak wood. ${ }^{1}$ In the second place, the nymph Egeria at Nemi appears to have been merely a form of Diana, and Egeria is definitely said to have been a Dryad, a nymph of the oak. ${ }^{2} \quad$ Elsewhere in Italy the goddess Diana had her home on oak-clad mountains. Thus Mount Algidus, a spur of the Alban hills, was covered in antiquity with dark forests of oak, both of the evergreen and the deciduous sort. In winter the snow lay long on these cold hills, and their gloomy oak woods were believed to be a favourite haunt of Diana, as they have been of brigands in modern times. ${ }^{3}$ Again, Mount Tifata, the long abrupt ridge of the Apennines which looks down on the Campanian plain behind Capua, was wooded of old with evergreen oaks, among which Diana had a temple. ${ }^{4}$ On the whole, then, we conclude that at Nemi the King of the Wood personated the oak god Jupiter and mated with the oak goddess Diana in the sacred grove. An echo of their mystic union has come down to us in the legend of the loves of Numa and Egeria, who, according to some, had their trysting-place in these holy woods. ${ }^{5}$

To this theory it may naturally be objected that

1 See above, pp. 209, 281.

2 See above, p. 196.

3 Horace, Odes, i. 21.5 sq., iii. 23.9 sq., iv. 4. 5 sq., Carmen Saeculare, 69 ; Livy, iii. 25.6-8 ; E. H. Bunbury, in Smith's Dictionary of Greek and Roman Geography, s.v. "Algidus."

4 Festus, s.v. "Tifata," p. 366, ed. C. O. Müller; Velleius Paterculus, ii. 25. 4 ; E. H. Bunbury, op. cit. s.v. "Tifata." For more evidence of the association of Diana with the oak, see Mr. A. B. Cook, "Zeus, Jupiter, and the Oak," Classical Reviezu, xviii. (1904), pp. 369 sq.

5 See above, pp. 22, 195, 217. 
the divine consort of Jupiter was not Diana but Juno, and that if Diana had a mate at all he might be expected to bear the name not of Jupiter but of Dianus or Janus, the latter of these forms being merely a corruption of the former. All this is true, but the objection may be parried by observing that the two pairs of deities, Jupiter and Juno on the one side, and Dianus and Diana, or Janus and Jana, on the other side, are merely duplicates of each other, their names and their functions being in substance and origin identical. With regard to their names, all four of them come from the same Aryan root $D I$, meaning bright, which occurs in the names of the corresponding Greek deities, Zeus and his old female consort Dione. ${ }^{1}$ In regard to their functions, Juno and Diana were both goddesses of fecundity and childbirth, and both were sooner or later identified with the moon. ${ }^{2}$ As to the true nature and functions of Janus, the ancients themselves were puzzled; ${ }^{3}$ and where they hesitated, it is not for us confidently to

1 The original root appears plainly in Diovis and Diespiter, the older forms of Fupiter (Varro, De lingua Latina, v. 66; Aulus Gellius, v. 12). The form Dianus is attested by an inscription found at Aquileia (C.I.L. v. No. 783 ), and the form Jana by Varto (De re rustica, i. 37. 3) and Macrobius (Saturn. i. 9. 8). As to the etymology of these names, see Ch. Ploix, "Les dieux qui proviennent de la racine DIV," Mémoires de la Société de Linguistique de Paris, i. (1868), pp. 213-222; G. Curtius, Grunzilge aer griech. Etymologie, pp. 236 sq., 616 sq.; A. Vanitek, Griechisch. Lateinisches Etymologisches Worterbuch, i. 353 sqq.; J. S. Speijer, "Le dieu romain Janus," Revue de l'Hissoire des Religions, xxvi. (1892), pp. 37-41; H. Usener, Gobsernamen (Bonn, 1896), pp. 16, 35 sq., 326 ; P. Kretschmer, Einleirung in die Geschichee der griechischen Sprache (Grttingen, 1896), pp. 78 sqq., 91 , 161 sq. Messrs. Speijer and Kretschmer reject the derivation of Fanus from the root DI.

${ }^{2}$ As to Juno in these aspects, see L. Preller, Rormische Mythologie, ${ }^{3}$ i. 271 sq9.; G. Wissowa, Religion und Kultus der Romer, pp. 117 sq9.; W. H. Roscher, Lexikon d. griech. u. röm. Myshclogic, ii. 578 sq9. As to Diana, sec above, pp. 13 sqq., 16 sqg.

s Ovid, Fasti, i. 89 sq9.; Macrobius, Sat. i. 9 ; Servius, on Virgil, Aen. vii. 680 ; Joannes Lydus, De mensibus, iv. I sq. 
decide. But the view mentioned by Varro $^{1}$ that Janus was the god of the sky is supported not only by the etymological identity of his name with that of the sky god Jupiter, but also by the relation in which he appears to have stood to Jupiter's two mates, Juno and Juturna. For the epithet Junonian bestowed on Janus ${ }^{2}$ points to a marriage union between the two deities; and according to one account Janus was the husband of the water nymph Juturna, ${ }^{3}$ who according to others was beloved by Jupiter. ${ }^{4}$ Moreover, Janus, like Jove, was regularly invoked, and commonly spoken of, under the title of Father. ${ }^{5}$ Indeed, he was identified with Jupiter, not merely by the logic of a Christian doctor, the great Augustine himself, ${ }^{6}$ but by a pagan worshipper who dedicated an offering to Jupiter Dianus. ${ }^{7}$ A trace of his relation to the oak may be found in the oak woods of the Janiculum, the hill on the right bank of the Tiber, where Janus is said to have reigned as a king in the remotest ages of Italian history. ${ }^{8}$

Thus, if I am right, the same ancient pair of deities

1 Varro, quoted by Augustine, $D e$ civitate Dei, vii. 28 ; Joannes Lydus, $D e$ mensibus, iv. 2. Compare Macrobius, Sat. i. 9. I I.

2 Macrobius, Sat. i. 9. 15, i. 15. 19 ; Servius, on Virgil, Aen. vii. 610; Joannes Lydus, De mensibus, iv. I.

3 Arnobius, Adversus Nationes, iii. 29.

4 Virgil, Aen. xii. $13^{8}$ sqq.; Ovid, Fasti, ii. 585 sqq.

5 Cato, De agri cultura, 134; Virgil, Aen. viii. 357 ; Horace, Epist. i. 16. 59, compare Sat. ii. 6. 20 ; Pliny, Nat. Hist. xxxvi. 28 ; Juvenal, vi. 394 ; Martial, x. 28. 6 sq.; Aulus Gellius, v. 12. 5 ; Arnobius, Adversus Nationes, iii. 29 ; H. Dessau, Inscriptiones Latinae Selectae, Nos. 3320, 3322, 3323, 3324, 3325, 5047 ; G. Henzen, Acta Fratrum Arvalium, p. 144; Athenæus, xv. 46, p. 692 d e.

6 Augustine, De civitate Dei, vii. 9 sq.

7 C.I.L. v. No. 783 .

8 Macrobius, Sat. i. 7. 19 ; Servius, on Virgil, Aen. viii. 319 and 357; Arnobius, Aidversus Nationes, iii. 29 ; Athenæus, xv. 46, p. 692 d. As to the oak woods of the Janiculum, see Pliny, Nat. Hist. xvi. 37 ; O. Richter, Topographie der Stadt Rom $^{2}$ (Munich, 1901), p. 211. 
was variously known among the Greek and Italian peoples as Zeus and Dione, Jupiter and Juno, or Dianus (Janus) and Diana (Jana), the names of the deities being identical in substance, though varying in form with the dialect of the particular tribe which worshipped them. At first, when the peoples dwelt near each other, the difference between the deities would be hardly more than one of name; in other words, it would be almost purely dialectical. But the gradual dispersion of the tribes, and their consequent isolation from each other, would favour the growth of divergent modes of conceiving and worshipping the gods whom they had carried with them from their old home, so that in time discrepancies of myth and ritual would tend to spring up and thereby to convert a nominal into a real distinction between the divinities. Accordingly when, with the slow progress of culture, the long period of barbarism and separation was passing away, and the rising political power of a single strong community had begun to draw or hammer its weaker neighbours into a nation, the confluent peoples would throw their gods, like their dialects, into a common stock; and thus it might come about that the same ancient deities, which their forefathers had worshipped together before the dispersion, would now be so disguised by the accumulated effect of dialectical and religious divergencies that their original identity might fail to be recognised, and they would take their places side by side as independent divinities in the national pantheon. ${ }^{1}$

3 Mr. A. B. Cook, who accepts my theory of the original identity of Jupiter and 
This duplication of deities, the result of the final fusion of kindred tribes who had long lived apart, would account for the appearance of Janus beside Jove, and of Diana or Jana beside Juno in the Roman religion. At least this appears to be a more probable theory than the opinion, which has found favour with some modern scholars, that Janus was originally nothing but the god of doors. ${ }^{1}$ That a deity of his dignity and importance, whom the Romans revered as a god of gods and the father of his people, should have started in life as a humble, though doubtless respectable, doorkeeper, appears to me, I confess, very unlikely. So lofty an end hardly consorts with so lowly a beginning. It is more probable that the door ( $j a n u a$ ) got its name from Janus than that he got his from it. This view is strengthened by a consideration of the word janua itself. The regular word for door is the same in all the languages of the Aryan family from India to Ireland. It is dur in Sanscrit, thura in Greek, thiir in German, door in English, dorus in old Irish, and foris in Latin. $^{2}$ Yet besides this ordinary name for door, which the Latins shared with all their Aryan brethren, they had also the term janua, which has nothing corresponding

Janus, Juno and Diana, has suggested that Janus and Diana were the deities of the aborigines of Rome, Jupiter and Juno the deities of their conquerors. See his article, "Zeus, Jupiter, and the Oak," Classical Review, xviii. (1904), pp. 367 sq.

1 This is the opinion of Dr. W. H. Roscher (Lexikon d. griech. und röm. Mythologie, ii. 47), Mr. W. Warde Fowler (Roman Festivals of the Period of the Republic, pp. 282 sqq.), and Prof. G. Wissowa (Religion und Kultus der Romer, p. 96). It is rejected for the reasons given in the text by $\mathrm{Ph}$. Buttmann (Mythologus, ii. pp. 72, 79) and S. Linde (De Fano summo Romanorum deo, pp. 50 sqq.).

2 G. Curtius, Grundzüge der griechischen Etymologie, ${ }^{5}$ p. $25^{8}$; O. Schrader, Reallexikon der Indogermanischen Altertumskunde (Strasburg, I901), p. 866. 
to it in any Indo-European speech. The word has the appearance of being an adjectival form derived from the noun fanus. I conjecture that it may have been customary to set up an image or symbol of Janus at the principal door of the house in order to place the entrance under the protection of the great god. A door thus guarded might be known as a janua foris, that is, a januan door, and the phrase might in time be abridged into janua, the noun foris or door being understood but not expressed. From this to the use of janua to designate a door in general, whether guarded by an image of Janus or not, would be an easy and natural transition. ${ }^{1}$ If there is any truth in this conjecture, it may explain very simply the origin of the double head of Janus, which has so long taxed the ingenuity of mythologists. When it had become customary to guard the entrance of houses and towns by an image of Janus, it might well be deemed necessary to make the sentinel god look both ways, before and behind, at the same time, in order that nothing should escape his vigilant eye. For if the divine watchman always faced in one direction only, it is easy to imagine what mischief might have been wrought with impunity behind his back.

To apply these conclusions to the priest of Nemi, we may suppose that as the mate of Diana he represented originally Dianus or Janus rather than Jupiter, but that

1 This explanation of the derivation of janua from Fanus was suggested, but not accepted by Ph. Buttmann (Mythologus, ii. 79 s99.). It occurred to me independently. Mr. A. B. Cook also derives janua from Fanus, but he would explain the derivation by supposing that the lintel and two side-posts of a door represented a triple Janus. See his article "Zeus, Jupiter, and the Oak," Classical Review, xviii. (1904), p. 369. 
the difference between these deities was of old merely superficial, going little deeper than the names, and leaving practically unaffected the essential functions of the god as a power of the sky, the thunder, and the oak. If my analysis of this great divinity is correct, the original element in his composite and apparently incongruous nature was the oak. Time does not permit me to set forth the reasons for this conclusion: you will find them stated in the new edition of my book. In any case it was natural that the human representative of the oak god at Nemi should dwell, as we have seen reason to believe he did, in an oak grove. His title of King of the Wood clearly indicates the sylvan character of the deity whom he served; and since he could only be assailed by him who had plucked the bough of a certain holy tree, his own life might be said to be bound up with that of the tree. Thus he not only served but embodied the great Aryan god of the oak; and as an oak god he would mate with the oak goddess, whether she went by the name of Egeria or Diana. Their union, however consummated, would be deemed essential to the fertility of the earth and the fecundity of man and beast. Further, as the oak god had grown into a god of the sky, the thunder, and the rain, so his human representative would be required, like many other divine kings, to cause the clouds to gather, the thunder to peal, and the rain to descend in due season, that the fields might bear fruit and the pastures be covered with luxuriant herbage. It was appropriate therefore that the worship of a god who dealt so much in water should 
be established on the shore of a lake, and that his divine consort Egeria should be in one of her aspects the nymph of a spring.

The reputed possessor of powers so exalted must have been a very important personage; and the evidence I adduced in the first lecture suffices to prove that the sanctuary at Nemi was one of the greatest and most popular in Italy. It was fitting that the ancient Aryan worship of the god of the oak and the dripping sky should here linger so long in its early, almost Druidical, form among the green woods and beside the still waters of the Alban hills, until a great political and intellectual revolution shifted the seat of Latin religion from the forest to the city, from Nemi to Rome.

I have nearly done with the priest of Nemi. Yet it may occur to you that I have left at least one important question unanswered. If the priest embodied a god, why expose his precious life to the risk of a mortal combat which so often proved fatal to him? why extinguish the divine light instead of husbanding it to its close? To ask this is to raise the question why it has been customary in many parts of the world to put divine kings and other human gods to a violent death. I cannot discuss that question fully in the few minutes that remain, but $I$ will give my answer to it very briefly. People feared that if they allowed the man-god to die of sickness or old age, his divine spirit might share the weakness of its bodily tabernacle, or perhaps perish altogether, thereby entailing the most 
serious dangers on the whole body of his worshippers who looked to him as their stay and support. Whereas, by putting him to death while he was yet in full vigour of body and mind, they hoped to catch his sacred spirit uncorrupted by decay and to transfer it in that state to his successor. Hence it has been customary in some countries, first, to require that kings should be of unblemished body and unimpaired mind, and second, to kill them as soon as they begin to break up through age and infirmity. A more stringent application of these principles led in other places to a practice of allowing the divine king or human god to live and reign only for a fixed period, after which he was inexorably put to death. The time of grace granted to limited monarchs of this sort has varied from several years to one year or even less. The late Miss Mary Kingsley called my attention to a province of the Congo region in West Africa where the king's life and reign are limited to a single day. She was personally acquainted with the chief who, a few years ago, possessed but declined to exercise the fatal right of succession. ${ }^{1}$ On the analogy of such customs I conjecture that the King of the Wood at Nemi formerly reigned for a fixed period only, probably for a year, and that he had to slay himself or be slain at a great festival when his term of office was up. This conjecture is confirmed by the recently discovered account of the Saturnalia of the Roman soldiers of which I have already spoken; for that account makes it

1 R. E. Dennett, Notes on the Folklore of the Fjort (London, 1898), p. xxxii. 
probable that the King of the Saturnalia, as he was called, personated Saturn, and that in early times he was obliged, after a brief and licentious reign, to cut his own throat on the altar at the god's great festival. If that was so, a practice of the same sort may well have existed at Nemi. Whether the king perished in the character of Saturn or of Jupiter was a matter of detail rather than of principle : perhaps, as I have conjectured, a dynasty of mortal Jupiters may have been preceded by a dynasty of mortal Saturns.

Further, I conjecture that the old rule of putting the King of the Wood to death at the end of a fixed period may afterwards have been mitigated into a custom of letting him live and reign so long as he could defend himself against all comers in single combat; for if he could do so, it might be taken as a sufficient proof that he was still fit to discharge his important duties, and that the dreaded decay of his divine powers had not yet set in. This conjecture may be supported by the analogy of the kingdom of Calicut, on the Malabar coast of Southern India, where such a change of practice is actually recorded to have taken place. In former days the king of Calicut had to cut his throat in public at the end of a reign of twelve years. ${ }^{1}$ But towards the close of the seventeenth century the stern old rule had been modified as follows. At the end of the twelve years a great festival was celebrated with mirth and jollity, and any man who pleased was free to attack the

1 Barbosa, A Description of the Coasts of East Africa and Malabar in the beginning of the Sixteenth Century (Hakluyt Society, 1866), pp. 172 sq. 
king, and, if he killed him, to reign in his stead. The permission, however, was little more than an empty form, since the king took good care on these occasions to surround himself with his guards. Still there were always found men brave and reckless enough to throw away their lives in a vain attempt to fight their way through the soldiery and win for themselves a crown at the point of the sword. The custom was observed down to I743. Exact records of the festivals and of the number of men who perished at them are still preserved in the archives of the royal family. They were examined by Mr. W. Logan, with the personal assistance of the reigning king, about twenty years ago. As these festivals furnish the closest modern parallel to the practice of Nemi, I propose to conclude my lectures with a description of them. ${ }^{1}$

The festival at which the king of Calicut staked his crown and his life on the issue of battle was known as the Maha Makham or Great Sacrifice. It fell every twelfth year, when the planet Jupiter was in retrograde motion in the sign of the Crab, and it lasted twentyeight days, culminating at the time of the eighth lunar asterism in the month of Makaram. As the date of the festival was determined by the position of Jupiter in the sky, and the interval between two festivals was

1 See W. Logan, Malabar (Madras, 1887), i. 162-169. The writer describes in particular the festival of 1683 , when fifty-five men perished in the manner described. A brief account of the following festival, that of 1695 , was published by Alexander Hamilton, an English traveller who passed along the coast at that time and heard the sound of the guns for two or three days in the distance. See Alex. Hamilton, "A New Account of the East Indies," in Pinkerton's Voyages and Travels, viii. 374 . 
twelve years, which is roughly Jupiter's period of revolution round the sun, ${ }^{1}$ we may conjecture that the splendid planet, which with the still brighter star of Venus has lately been illuminating the western firmament every evening, was supposed to be in a special sense the king's star and to determine his destiny, the period of its revolution in heaven corresponding to the period of his reign on earth. However that may be, the ceremony was observed with great pomp at the Tirunavayi temple, on the north bank of the Ponnani river. The spot is close to the present railway line. As the train rushes by, you can just catch a glimpse of the temple, almost hidden behind a clump of trees on the river bank. From the western gateway of the temple a perfectly straight road, hardly raised above the surrounding rice-fields and shaded by a fine avenue, runs for half a mile to a high ridge with a precipitous bank, on which the outlines of three or four terraces can still be traced. On the topmost of these terraces the king took his stand on the eventful day. The view which it commands is a fine one. Across the level expanse of the rice-fields, with the broad placid river winding through them, the eye ranges eastward to high flat-topped tablelands, their lower slopes embowered in woods, while afar off looms the great chain of the Western Ghauts, and in the furthest distance the Neilgherries or Blue Mountains, hardly distinguishable from the azure of the sky above.

1 The sidereal revolution of Jupiter is completed in 11 years 314.92 days (Encyclopadia Brisannica," s.v. "Astronomy," ii. 808). 
But it was not to the distant prospect that the king's eyes naturally turned at the fateful hour. His attention was arrested by a spectacle nearer at hand. For all the plain below was alive with troops, their banners waving gaily in the sun, the white tents of their many camps standing sharply out against the green and gold of the rice-fields. Forty thousand fighting men or more were gathered there to defend the king. But if the plain swarmed with soldiers, the road that cuts across it from the temple to the king's stand was clear of them. Not a soul was stirring on it. Each side of the road was barred by palisades, and from the palisades on either hand a long hedge of spears, held by strong arms, projected into the empty road, their blades meeting in the middle and forming a glittering arch of steel. All was now ready. The king waved his sword. At the same moment a great chain of massy gold, enriched with bosses, was placed on an elephant at his side. That was the signal. On the instant a stir might be seen half a mile away at the gate of the temple. A group of swordsmen, decked with flowers and smeared with ashes, has stepped out from the crowd. They have just partaken of their last meal on earth, and they now receive the last blessings and farewells of their friends. A moment more and they are coming down the lane of spears, hewing and stabbing right and left at the spearmen, winding and turning and writhing among the blades as if they had no bones in their bodies. It is all in vain. One after the other they fall, some nearer the king, some further off, 
content to die, not for the shadow of a crown, but for the mere sake of approving their dauntless valour and swordsmanship to the world. On the ten last days of the festival the same magnificent display of gallantry, the same useless sacrifice of life, was repeated again and again. Yet perhaps no sacrifice is wholly useless which proves that there are men who prefer honour to life.

That is an Indian parallel to the priest of Nemi. 



\section{INDEX}

Abbas Effendi, head of the Babites, 139 Abolition of kingship at Rome, 25I sqg.

Achilles, 239

Adonis, 25, 26, 27

Eacus, 239

Egisthus, 242

Eneas, his end, 205

Africa, chiefs and kings in, 112 sqg.; female descent of kings in, 235 s99. ; kingship in, 254 sq9.

Agamemnon, 240; sceptre of, 124 note Agrigentum, 137

Ainos of Japan, 44, 93 sq.

Alba, kings of, 201 s99., 229 s99.

Alban hills, 9 sq., 210 sqg.

Alcidamus, 261

Algidus, Mount, 211 ; its oak woods, 284

Alitemnian Libyans, race for kingdom among the, 260

Amata, wife of Latinus, 221

American Indians, their magical images, $41 \mathrm{sq}$.

Ammon, Egyptian god, 171 sq.

Amulius Silvius, 203 sq.

Anaitis, 21 sq.

Ancus Marcius, King, 274

Angamis of Manipur, 94

Angola, 255

Animal-headed gods, 172

Animals, magic of, 69 sqg.

Anne, Queen, touches for scrofula, 126

Antaus, king of Libya, 261

Anthropology, its position and methods, 2 s99.

Antigonus deified by the Athenians, 137

Anula, tribe of North Australia, 95

Apollo at Patara, 173

Araucanians of Chili, 206

Archons at Athens, 73

Aricia, 10, 12, 13; Arician grove, 280

Aristotle, on priestly kings, 29
Arjun, Indian prince, 262

Armenian Church, 21 sq. ; charms, 97

Artemis, 14 sq.; of Ephesus, 14, 173 sq.

Aryan sacred fires of oak wood, 209; god of the sky, the thunder, and the oak, 290 sq.; female descent among Aryan peoples, $23^{8}$ sq., 241, 245 sqq.

Ascanius, 221

Ascension Day, 164, 187, 188, 191

Ashantee, female descent of kings in, 235 sq.

Association of ideas, mistaken, 39, 150

Assumption of the Virgin, 18 sqg.

Assyrian sculptures, 155

Athena, mother of Erichthonius, 222

Athens, stone at, 73 ; marriage or Dionysus at, 174 sq.; succession to kingship at, $23^{8}$; kingship at, 252

Athletic contest, succession to kingship determined by, 260 sqg.

Atreus, 240

Attica, female kinship in, 245

Attis, 22, 25, 26, 27

August, $13^{\text {th }}$ and $15^{\text {th }}$ of, 17,18 sq9.

Augustine, on Janus, 286

Augustus, 84 ; his oaken crown, 199 sq.

Australia, headmen in, 107 sq9.; totemism in, $107 \mathrm{sq}$.

Australian magic, 50, 77 sq., 80, 93, 95

Autun, ancient ceremony at, 178

Babites, Persian sect, 139

Babylon, sanctuary of $\mathrm{Bel}$ at, 170

Babylonian kings deified, 147

Baganda of Central Africa, 179 ; their kings, 230

Bagba, a fetish, 106

Ball-players, superstitions of, 65,70

Bangalas of Angola, chieftainship among the, 255

Banyai, government of the, 255

Barce, daughter of Antaus, 261

Bary, tribe on the Nile, 115 
Basil, the Holy, in India, 1;6 sq7.

Battus, 31

Batutah, Ibn, Arab traveller, 181 sq.

Bede, on Pictish kings, 247

Becna marriage, 232 sq.

$\mathrm{Bel}$, his sanctuary and wife, 170

Belep, tribe of New Caledonia, 68

Benzoni, G., on the name Viracocha, 42 sq.

Bibili, 105

Bima, in Celebes, 123

Birds used in cure for jaundice, $4^{8} \mathrm{sq}$.

Black colour in magic, 97 sq.

Black foot Indians, 68

Boars, wild, hunted in Italy, 14

Bcootian festival, $176 \mathrm{sq}$.

Bohemian superstition, 80 sq.

Bongo of Upper Nile, the, 114 sq.

Boni, G., 209

Borneo, $43 \mathrm{sq}$.

Bovilla, 203

Brahman may not breathe on fire, 224

Brahmans, 72 ; morning offerings of, 102 ; worshipped in India, 139 sq.

Brazilian Indians, 56 ; their medicinemen, 130

Brigit, Celtic goddess, 222 sq.

Brothers of king put to death, 236 sqq.

Bructeri, German tribe, 139

Brunhild, queen of Iceland, 262

Brutus, L. Junius, first consul, 25 I sq., 254

Brutus, the assassin, at Nemi, 12

Buckthorn used to keep out witches, 215

Bull, Dionysus in form of, 174

Bulls, white sacrificial, 211,212

Burglars, charms employed by and against, 67 sq., 80

Burma, Shans of, 62 ; marriage of maidens to water-spirit in, 179 sq.

Burs in magic, 65

Buttmann, Ph., 288 note I, 289 note I

Buzzard, superstition as to, 70

Cadys, king of Lydia, 242

Cæculus, a son of Vulcan, 220

Cælian hill, 2 I 4

Cæsar, Julius, I1, I 3,84 ; Lucius, I 2

Cæsars, the, 203

Caffres, chiefs and rain-makers among, I 18 sq9.; corpulence a mark of nobility among the, 259

Calah, old capital of Assyria, 171

Calicut, king of, his tenure of the throne, 293 sqg.

Caligula at Nemi, 13

Camphor, superstitions as to, 55 sq., 59
Candaules, king of Lydia, $2+2$

Candlemas, 225

Cantabrians, 245 sq.

Canute, his marriage, 243 sq.

Capillary attraction, $50 \mathrm{sq}$.

Capitol, temple of Jupiter on, 197 sqq. ; temple of Juno on, 208 ; sacred oak on, 199, 208

Caprificatio, 270 note 2

Caprificus, 270

Caprotina, epithet of Juno, 270

Carna, a nymph, 214

Casina of Plautus, 282

Castor and Pollux, 32 s79.

Cat's cradle, 54 sq., 104

Cattle in relation to Diana, $14 \mathrm{sq}$.

Catullus, on Diana, 13

Cecrops, 238, 245

Celebes, Toradjas of, 5 I sq., 60, 95 sq.; regalia in, 12 I sqg.

Celtic and Italian languages akin, 213

Celts, perpetual sacred fires among the, 222 sq.

Cenæd, king of the Scots, 247

Chadwick, H. M., 239, 241, 242 note 2, 244 note

Chaka, the Zulu despot, 119

Champion at coronation ceremony, 275 sq.

Charles II. touches for scrofula, 126; his coronation, 276

Cherokees, their superstitions, 65 sq., 66 , 70 sq., 72, 105

Cherrington and Stourton, in Warwickshire, 166 sq.

Chiefs developed out of magicians, 106 sqq.; as rain-makers, 112,116 sqq.

Chieftainship in New Guinea, 110 sq.; in Melanesia, 111 sq.; in Africa, 112 sqg.

Chili, Araucanians of, 206

China, human gods in, 142 sqg.; emperor of China worshipped, $146 \mathrm{sq}$.

Chinchvad, near Poona, human gods at, $140 \mathrm{sg}$.

Chinese Government, its regulations as to human gods, 143

Chinese modes of procuring or stopping rain, $9^{8} s q$.

Chios, kings of, 29 sq.

Chippeways, 41, 45

Chissumpe, the, 134 sq.

Cholones, Indian tribe, 56

Cicero at Nemi, 12.

Circe, the land of, 212

Cirta, image of Jupiter at, 200

Cithæron, Mount, 176, 177

Civilisation spread by conquering races, 
86 sq.; first civilisations arise under despotic governments, 87

Claudius, Emperor, perpetual lamp for, 17 ; as Jupiter, 200 note I ; his Etruscan history, 232 note 3

Clown at Whitsuntide, 164 sq.

Clytæmnestra, 240

Codrington, Dr. R. H., III

Codrus, 3 I

Collatinus, L. Tarquinius, first consul, 252

Cologne, 139

Colours in magic, 47 sq9., 97 sq.

Columella, 270

Compulsion applied to gods and spirits, $9^{8}$ sq9.

Congo, kingship in, 275, 292

Conquering races, their influence on civilisation, 86 sq.

Conquest in relation to progress, $86 \mathrm{sq}$.

Consuls at Rome, institution of, 251 sq9.

Contagion or contact, law of, 37 sqq.

Contagious magic, 37 s99., 77 s9q.; contagious taboo, 59

Contest, athletic, for kingship, 260 s99. ; for a wife, 261 sqg.

Conybeare, F. C., 2 I

Cook, A. B., 18, 21 note 2,26 note 3, 176 note 1, 196, 197 note 1, 202 note 2, 206, 211 note 2, 216 note 1, 252 note 2,263 note $1,274,282,283$ note I, 284 note 4,287 note 1,289 note I

Cora Indians, 41

Corn-mother at Eleusis, 175 sq.

Corpulence a mark of nobility in Africa, 259

Corpus Christi Day, Sunday after, 185

Cos, king of, 29

Crocodiles, girls married to, $180 \mathrm{sq}$.

Cronus, older god than Zeus in Greece, 277

Crooke, W., 14 I note I

Crown, king's, treated as divine, 124 note I ; crown of oak leaves, 198, 199 sq., 202, 207

Cumont, Prof. F., 267

Cup and ball, 104

Cures, magical, 47 sqg.

Curses, public, 30

Curtiss, Prof., S. I., 139

Cuttle-fish, 72

Cuzco, temple of the sun at, 227

Cybele, 22, 26, 27, 178

Cyrene, kings of, 31

Dxdala, Beotian festival, 177

Dalai Lama, 142

Danaus, 26 I
Date Month, 155

Dead, prayers to the, 32, 74 sq., 97, 120 ; magic of the, $67 \mathrm{sq}$.; rain-charms by means of the, 94 sq., 97 sq.; spirits of the, cause tempests, 206

Deaths, mysterious or violent, of Latin and Roman kings, 204 sq9., 269, 273 sqg.

Deductive method, 4

Deer, 70, 7 I, 8 I

Deification of deceased mandarins, 145

Deir el Bahari, 171

Deities, duplication of, $285 \mathrm{sq}$.

Demeter married to Zeus, $175 \mathrm{sq}$.

Demetrius Poliorcetes deified by the Athenians, 137 sq.

Derry, oaks of, 226

Despotism, its influence on civilisation, 87 ; its decay, 152

Destiny, modes of circumventing, 75 sqq.

Devil's shoestring, 65

Diagara, kingship in, 255

Diana of Nemi, 9 sqq., 152 sqq.; god. dess of hunters, 13 sq. ; of cattle, 14 sq.; of childbirth, $17,280,285$; of fire, 17 sq.; her festival, 17, 18 sq. ; of Ephesus, 14, 173 ; goddess of vines and fruit-trees, $18 \mathrm{sqg.;} \mathrm{in} \mathrm{relation} \mathrm{to}$ Virbius, 24 s99.; mated with her priest at Nemi, 26 sq., I 53 sq., 160, 169, 194 sq., 284,290 ; as Queen of the Wood, 26 note 3,280 sq., 283 ; a double of Juno, 214 sq., 285 sqq.; goddess of the oak, 283 sq. ; goddess of fertility and childbirth, 280,285

Dianus or Janus, an equivalent of Jupiter, 285 sqq. See also Janus

Differentiation of function, its part in social progress, I 50 sq.

Dinka or Denka nation, I 15

Diomede, 240

Dione, 213 ; old consort of Zeus, 285

Dionysius of Halicarnassus, on the Etruscans, 248 note 4

Dionysus, 199; married to queen of Athens, 174 sq.

Divine kings put to death, 29 I sqg.

Divinity of kings, 32, 34, 128, 132 sq9., 280

Division of labour essential to social progress, 150

Dodona, 200, 213 ; Zeus of, 200

Doors in relation to Janus, $288 \mathrm{sq}$.

D'Orville, Father, 142

Dos Santos, Portuguese historian, quoted, $133 \mathrm{sq}$.

Double kingship, 252

Dragon of rain, $98 \mathrm{sp.}$; of water, $1 \$_{3}$ 
sq.; slaying of the, 185 sq.; of Rouen, 186 sq9.; of Tarascon, 190 note I

Draupadi, in the Mahabharata, 262

Dropsy, prevention of, 47

Druids, their sacrifice at cutting the mistletoe, 212 ; female, 224 note

Drums, making of, in New Guinea, 62 sq.

Duplication of deities, $285 \mathrm{sqg}$.

Dynasties of alien origin, 249

Eagle-hunters, magic of, 68

Economic progress furthered by conquest and empire, 86 ; dependent on division of labour, $150 \mathrm{sq}$.

Edbald, king of Kent, 244

Effigies, magical, 41 sq9.

Egeria, 22 sq.; her relation to Numa, 22, 195, 217, 284; an oak nymph, identical with Diana, 196, 284, 290

Egyptian animal-headed gods, 172

Egyptian kings deified, $14 \mathrm{~S}$ sq.; identified with Ammon, 171 sq.

Elective and hereditary monarchies, 254 s79.

Electric lights on spears and mastheads, 33 sq.

Eleusis, mysteries of, $175 \mathrm{sq}$.

Emma, wife of Canute, 243 sq.

Empedocles, his claim to divinity, I 37

Emperors of China and Japan deified, $146 \mathrm{sq}$.

Empire, benefits of, 86 sq.

Endymion, loved by the Moon, 22 ; sets his sons to race for kingdom, $260 \mathrm{sq}$.

English superstition, 78

Ephesus, Artemis of, 16, 173 sq.; kings of, $3^{1}$; King Bees at, 173

Epizephyrian Locrians, 245

Erichthonius, 25, 222

Esquiline hill, oak groves of, 274

Esquimaux, 69; blood-revenge among, 16 ; their magic 54 sq., 58 sq., 104

Essenes at Ephesus, 173

Etatin in Nigeria, I 17

Ethelbald, king of the West Saxons, 244

Ethelbert, king of Kent, 244

Etheired, king of England, 243

Ethelwulf, king of the West Saxons, 244

Ethiopians, descent of crown in female line among the, 259

Etruscans, female kinship among the, 248 ; their Lydian origin, 248

Evergreens tend to oust deciduous trees in Italy, I 5

Evolution, social and political, conditions of, 82 sq7., 149 sqq.
Execution, mock, 166

Exogamy at Rome, 232

Fairy banner, 125

Fallacies of magic, 39

Fan tribe of West Africa, 117

Fantee country, succession in, 235

February $24^{\text {th }}$, date of King's Flight at Rome, 264, 266

Female descent of Roman kingship, 231 sq9.; of African kingships, 235 sq9., 255,259

Female kinship, 232 sq.; in Europe, $2+5$ sqg.

Feng, uncle of Hamlet, 242, 244

Fertilisation, artificial, of the date palm, 155 ; of the fig, 270 sq.

Fierte or shrine of St. Romain, 188, 190

Fig, artificial fertilisation of, 270 sq.; as article of diet, $27 \mathrm{I}$ sq.; fig tree of Romulus, 272

Fire god, women married to, 218 sqq., 229

Fire, sacred, of Parsees, 224 ; not to be breathed on, 224 ; Peruvian ceremony of new, 227

Fires, sacred, of oak wood, 209, 281 ; perpetual sacred, among the Celts, 222 sqq.; vestal, 17 sq., 209, 218 sqq.

Fishers and hunters, magic of, 51 sq., 54 sqg.

Flamen Dialis, 202, $215 \mathrm{sq}$.

Flaminica, 2 I 5

Flight of the King, 252, 264 sgq.

Floquet, A., on the privilege of St. Romain, r9o sq.

Folk-tale of human sacrifices offered to water-spirits, 183 sq.

Footprints, magic of, $80 \mathrm{sq}$.

Foreign birth of Roman kings, 232, 234

Foreign kings, 232, 234,238 sq9., 247

Forum, Roman remains of vestal fire in, 209

Fox, superstition as to, 69, 71

French peasants, superstitions of, $5 \mathbf{I}$

Frey, Swedish god of fertility, $177 \mathrm{sq}$.

Frog, superstition as to, 70

Funerals, Roman, 200 sq.

Furth, Slaying of the Dragon at, $185 \mathrm{sq}$.

Futuna in South Pacific, 132

Galela, superstition in, 80

Gallas, 69

Garcilasso de la Vega, 43

Gardiner, J. Stanley, quoted, 182 sq.

Gaul, idolatrous ceremonies in, 178

German superstitious cures, 49 sq., 78 , 
Germans, the ancient, their worship of women $138 \mathrm{sq}$.; trace of female kinship among the, 246

Gerontocracy, 107

Glory, Hand of, 67 sq.

Godhead, savage idea of, $130 \mathrm{sg} 9$

Gods, conceived as invisible magicians, $130 \mathrm{sq.;}$ human gods, 35, 132 sq9., 279 sq.; the Saviour Gods, I37; Egyptian animal-headed, 172 ; evolution of, 279

Goliath, mock execution of the, 166

Gordioi, their kings, 259

Government, oligarchic, of savages, 84 ; despotic and theocratic governments, their influence on civilisation, 87 ; government of old men, 107

Greasing the weapon that inflicted the wound, 78

Greek, ancient, remedies, 47,48 sq., 69 ; housebreakers, 67 ; kings, 124 ; kings as embodiments of Zeus, $196 \mathrm{sq}$.

Greenidge, A. H. J., 258 note 2

Gregory of Tours, 178

Grove, sacred, 10, 14, 16, 22, 26, 27, $29,275,284$

Grueber, Father, 142

Guarayo Indians, 102

Gunputty, elephant-headed Hindoo god, $140 \mathrm{sq}$.

Gunther, king of the Burgundians, 262

Gyges, king of Lydia, $24^{2}$

Haddon, A. C., 150 note 1

Hadramaut, 94

Hadrian, 13

Hair, charms to promote the growth of, 50 sq., 69 ; long, symbol of royalty, 203

Half-sister, marriage with, in Attica, 245

Halford in Warwickshire, 167

Halmahera, 97

Hamilton, Alexander, 294 note I

Hamlet, 242, 254

Hammurabi, code of, 170

Hand of Glory, 67 sq.

Hardy, Thomas, 64 sq.

Harran, Sabzans of, I 55

Harris, J. Rendel, 18 note 7, 20, 25

Harrison, Miss J. E., 174

Hartland, E. S., 38,184 note I

Headmen in Australia, 107 sq9.

Heads artificially lengthened, 260

Heads of Janus, two, 289

Hearth, the Common, 29

Hearts of wax, 45

Heaven, God of, 144,146

Heavenly Master, the, 143 sqq.
Heine, H., Pilgrimage to Kevlaar, 45 sq. Helen, wife of Menelaus, 240

Helernus, grove of, 214 sq.

Heliopolis, 149

Hephastus, father of Erichthonius, 222

Hera and Zeus, sacred marriage of, 177

Hercules and Omphale, 243

Hereditary and elective monarchies, 254 sqg.

Hermigisil, king of the Varini, 244

Hermutrude, queen of Scotland, 242

Herodotus, on Spartan kings, 32 ; on Lydian kings, 243

Hestia, 29

Highland witches, 63

Hindoo magic, 45,47 sq., 50, 75

Hippocrates, on long-headed tribe, 260

Hippodamia, 240, 261

Hippolytus, 24 sq.

Hippolytus, Saint, 25

Hirn, Y., 38

Homeric kings, 124, 169 sq.

Homcopathic or imitative magic, 37 sq9.; homæopathic taboo, 59

Horse as public talisman, $123 \mathrm{sq}$.; races in Germany, 163,164; horses sacrificed to the sun, 103 sq.; Hippolytus killed by horses, 24, 25; white horses of Castor and Pollux, 33 sq.

Horus, the golden, 148

Housebuilding, woods unsuitable for, 66

Huichol Indians of Mexico, 69 sq.

Human gods, 128, 132 sq9., 279 sq.; Jupiters, 282 sq. ; sacrifices, 179 sqq., 192

Hunters and fishers, magic of, $5^{1}$ sq., 54 sqe.

Huzuls of Carpathians, 55, 64

Hyampolis in Phocis, Artemis at, 15

Hypothesis, the use of, 7 sq., 9 I

Ibn Batutah, Arab traveller, I81 sq.

Icarius, 26 I

Igaras, royal family of the, $256 \mathrm{sq}$.

Images, magical, 41 sq9.

Imitative or mimetic magic, 38

Impressions made by body, superstitions as to, 79 sqg.

Incarnation of god in human form, 128 , 132 sqq., 279 sq.

Incas of Peru, $226 \mathrm{sq}$.

India, human gods in, 139 sq. ; marriage of plants in, 156 sq9. ; Svayamvara in, 262

Indian tribes, their custom of lengthening the head, 260

Inductive method, 4 sqg.

Industrial progress furthered by conquest 
and empire, 86 ; dependent on division of labour, I $50 \mathrm{sq}$.

Institutions, history of, 2 sqq.; their origin in savagery, 2 sq., $6,3^{6}$ sq.

Intellectual progress inseparable from economic or industrial progress, 86

Interrex, 258

Invulnerability, 66 sq.

Iona, 226

Ireland, perpetual fires in, 223 sqq.; sacred oaks in, 225 sq.

Iron, magic of, 72

Italian and Celtic languages akin, $2 \times 3$

Italy, contrast between ancient and modern, $15 \mathrm{sg}$.

Iyyar or Airu, an Assyrian month, I7I

Jana or Diana, 285

Janiculum, oak woods of, 286

Fanua and Janus, 288 sq.

Janus or Dianus, equivalent to Jupiter, $21_{4}$ sq., $2 S_{5}$ sqq.; invoked as father, 286 ; mate of Juno and Juturna, 286 ; reigned on the Janiculum, 286 ; his relation to doors, $288 \mathrm{sq}$.; his two heads, 289 ; represented by the priest of Nemi, 289 sq.

Japan, Ainos of, 44; magic in, 80; emperor of, 147

Jaundice, magical cures for, 47 sqq.

Johnson, Dr., touched for scrofula, 126

Johnston, Sir Harry, 112

Jordan, H., 275 note

Judah, kings of, sacrifice to the sun, 103

Judith, widow of Ethelwulf, 244

Julii, the, 202 sq.

Julus, the Little Jupiter, 202, 22 I

July 7 th, Roman festival of, 269 sqq.

Juno, Capitoline, 208 ; Caprotina, 270 ; Moneta, 213 ; Jupiter and Juno, their sacred marriage, 214 sq.; a duplicate of Diana, 285,287

Jupiter, Capitoline, I1, 197 sqq., 208 ; embodied in Latin kings, 197 sq9., 207, 210; Indiges, 205; Elicius, 207 ; Latian, 210; and Juno, their sacred marriage, 214 sq.; a duplicate of Janus, 285,287 ; human and mortal Jupiters, $282 \mathrm{sq}$.

Jupiter, the king's star, 294 sq.

Juturna, a water nymph, 286

Karo-bataks of Sumatra, 96

Keats, quoted, 75

Kenyahs of Borneo, 44

Kevlaar, Virgin Mary of, 45

Kildare, nuns of St. Brigit at, 223 ; oak of St. Bride at, 225
King, license allowed to sisters of, 235 sq.; brothers of, put to death, 236 sq. ; marriage with widow of, 242 sqq.; Flight of the, 252, $264 \mathrm{sqg}$.

King of May, 159, 162 sq9.; Whitsuntide King, 164 sq.

King of the Sacred Rites, 258,264

King of the Saturnalia, 293

King of the Wood, 9, 16, 26 sq., 152 sqq., 160, 166, 169, 174, 194 sq9., 280 s9..; an embodiment of Jupiter or Janus, 28 I sqg.

King's daughter sacrificed, $183 \mathrm{sq}$.

King's evil, I 26

King's touch for scrofula, I 26

Kings, African, I12, 116 sq., I19 sq.; Malay, 120 sq.; Greek, 124, 238 sq9.; Scythian, 124 note; Babylonian, 147 ; Egyptian, 148 sq., 17 I sq9.; Roman, 197 sqq.; Alban, 201 sqq., 229 sqq.; Lydian, 242 sq.; Pictish, 242, 246 sq. ; Saxon, 244.

Kings, as magicians, 1,36 ; as rain-makers, I1 6 sq., 119 sq., 207

Kings, priestly, 29 sqq., 127 sq., 2 I 6 sq. ; divinity of, $32,34,128,132$ sqq., 280 ; developed out of public magicians, 82 sq9., 88, 106 sqq., 127, 129 sqq.; descended from Zeus, 169 sq.; embodiments of Zeus, 196 sq., of Jupiter, 197 sq9.; personal qualities of, $25^{8}$ sq9.; divine, put to death, 29 I sqq.

Kingship, evolution of, 28 sqq., 82 sqq., 89 sqq., 106 sqq., 127 sq., 129 sqq., 149 sqq.; succession to, 229 sqq.; double, $25^{2}$; limited tenure of, 252 , 254, 267, 29I sq9.; elective and hereditary, 254 s99.; athletic contests for, 260 sqg.

Kingsley, Miss Mary H., 292

Koepang, East Indian state, 180

Krishna, 157

Kurs of East Prussia, 64

Lac, superstition as to, 56

Lakshmi, wife of Vishnu, 156

Laos, province of Siam, 56, 94

Latian Jupiter, 2 ro

Latin kings embodiments of Jupiter, 197 sq9., 207, 210; thought to be sons of the fire god, 2 I 8 sqq., 229

Latinus, his mysterious end, 210

Latium, the woods of, 2 I 1 sq.; festival of the Nonae Caprotinae in, 270

Lavinia, 221

Laws of magic, 37 sqq.; of Manu, 139 sq.

Lendu, tribe of Central Africa, I 16 
Leo X., 14

Lerons of Borneo, 43 sq

Leucadia, 73

Lhassa, 142

Libyans, race for the kingdom among the Alitemnian, 260

License allowed to king's sisters, 235 sq.; to princesses in Loango, 237 sq.; of May Day, 162

Lippe, tributary of the Rhine, 139

Lithuanians, their sacred fires of oak, 210

Loango, royal blood traced in female line in, 237 sq.

Lo Bengula, king of the Matabeles, 119 , I35

Locrians, the Epizephyrian, 245

Logan, W., 294

Long Man, 65

Long-headed tribe described by Hippocrates, 260 ; long-headed kings, 259

Love, cures for, 45 sq., 73

Lucius, E., 20

Luxor, temple at, 171

Lydia, descent of kingship in, $242 \mathrm{sq}$.

Macedonian superstition, 64

MacGregor, Sir William, quoted, I 10

Macleods of Dunvezan, 125

Madagascar, cheating the fates in, 75 sqg.

Magic, older than religion, 35 ; its principles, 37 s99. ; homcopathic or imitative magic, $3^{8}$ sqg.; contagious magic, $3^{8}$ sqq., 77 sqq.; sympathetic magic, 38 ; theoretical and practical, 38 sq., 52 sqq.; blent with religion, 45 sq., 94,97 ; positive and negative, $52 \mathrm{sgq.;}$ to heal or prevent sickness, 47 s9q.; of hunters and fishers, 51 sq., 54 sq9.; of the dead, 67 sq., 97 sq.; of animals, 69 sq..; of inanimate things, 72 sq9.; of footprints, $80 \mathrm{sq}$. ; private and public, 8I sq.; benefits conferred by, $8_{3}$ sqg., $87 \mathrm{sq.;}$ in relation to science, 90 s9.; displaced by religion, 127, 279 ; fallacy of, 278

Magicians develop into kings, 8 I sqg., 88, 106 sq9., 127, 129 sqq., 149 sq9.; oldest professional class, 150

Maha Makham, the Great Sacrifice, at Calicut, 294

Mahabharata, the, 262

Maize, charms to promote growth of, 73

Makala god, 135 sq.

Makrisi, Arab historian, 94, 180 note 2

Malagese charms, 72, 75 49.

Malay kings or rajahs, 120 sq.; regalia, 121897.
Maldive Islands, sacrifice of women in, I 80 sqg.

Mandarins deified after death, 145

Manipur, 94

Mantras or sacred texts, 140

Manu, Laws of, 139 sq.

Maoris, 154

Mara tribe of N. Australia, 93

Maraves of S. Africa, 134

Marduk, god of Babylon, 170

Marriage of trees and plants, 155 sqg., 270 sq.; sacred marriage of deities, 169 sq9., I 94 sq9., 265 sq9.; of Jupiter and Juno, 214 sq.; of women to water spirits, 179 sq9.; of women to fire god, 218 sqq.; with stepmother, 244 ; with half-sister, in Attica, 245

Masai, medicine-men of the, 112 sq9.

Mashona god, 136

Maspero, Prof. G., quoted, 172

Massagetæ sacrifice horses to the sun, 104

Mastarna, 232 note 3

Matabeles, kings of, 3 I sq., I 9 sq.

May, King and Queen of, 159, 162 sq9.; bringing in the, $162 \mathrm{sq}$.

May Day ceremonies in Germany, 162 sqq.; in Warwickshire, 166 sq.; ancient equivalents of, $168 \mathrm{sq}$.

May-poles and May-trees, 162 sqq.

Mbatyan, Masai chief, 114

Medicine-men in Africa, 112 sq9. See also Magicians

Medontids at Athens, 252

Melanesia, chieftainship in, I I I sq.

Memory, charm to improve, 65 sq.

Menelaus, 240

Merker, Capt. M., 112 sqg.

Mexican Indians, 67. See also Cora, Huichol, Tarahumares.

Mexican sacrifices to the sun, IO2 sq.

Midsummer Day, Peruvian ceremony of new fire on, 227

Mikado, the, incarnation of sun goddess, 147

Minerva identified with Celtic Brigit, $223 \mathrm{sq}$.

Minotaur, 175

Misrule, Lord of, 266

Mistletoe, Druidical sacrifice at cutting the, 212 sq.

Mogk, E., quoted, 162 sq.

Mohammed, on the fig, 272

Mole-cricket, superstition as to the, 71

Mommsen, Th., 197 note 3, 198 note 1, $25^{8}$

Monarchies, elective and hereditary, 254 sqq. 
Monarchy, rise of, essential to civilisation, $84 \mathrm{sgq.}$ See also Kingship.

Moneta, title of Juno, 213

Mongolia, human gods in, 142 sq.

Moon, attempt to accelerate the, 105

Mooraba Gosseyn, a Brahman, 140

Moret, A., quoted, 148 sq., 173 note 1

Mother Goddess, 178

Mother Vesta, 222

Moulton, J. H., 213 note 2

Müller, K. O., 197 note 3

Murray Islanders, ro5 sq.

Mycena, 240, 242

Mytilene, kings of, 29

Nabu, marriage of the god, 171

Negative magic or taboo, 52 sq9.

Nemi, its position and sanctuary, 9 sqg., 152 sq9., 280 sq9.; priest of, 9, 16, 26, 27,278 sqq.

Neoptolemus, 239

New Caledonia, natives of, 46 sq., 68, 73 sqq., 101 sq.

New Guinea, magic in, 52, 62 sq., 105 ; chieftainship in, 110 sq.

New Hebrides, chieftainship in, I I I sq.

Niebelungenlied, 262

Niebuhr, B. G., 230

Nightingale, superstition as to, 69

Nile, girl thrown into, 180

Nonae Caprutinae, 270

Numa, adept in drawing down lightning, 204 ; as Flamen Dialis, 216 ; his fame, 274 ; and Egeria, 22, 195, 217,284

Numicius, river, 105

Nyanza region, rain-making in, 116 sq.

Oak, sacred to Jupiter, 198 ; on the Capitol, 199; at Dodona, 200 ; crown of oak leaves, 198, 199 sq., 202, 207 ; sacred fire of oak wood, 209 sq., 281 ; woods at Rome, 208 sq., 214, 274; Men of the, 211 ; of St. Bride, 225 ; sacred oaks in Ireland, $225 \mathrm{sq}$.; Aryan god of, 290

Ocrisia, mother of Servius Tullius, 2 I 8 sq.

Odomanti, a Thracian tribe, $\mathbf{2 6 2}$

Ojebways, 8 I

Old men, savages governed by, 84,107

Oligarchic government of savages, 84

Olympia, races for the kingdom at, 260 sq.

Omphale, queen of Lydia, 243

Orchha, rajah of, $15^{8}$

Ordeal of battle among the Umbrians, 275

Orestes, 73

Ovid, quoted, 199
Palatine hill, 209

Palladius, 270

Pallene, daughter of Sithon, 262

Palm, artificial fertilisation of the date, 155

Paloppo in Celebes, 123

Papuans of Tumleo, 78 sq. See also New Guinea.

Parilia, 19

Parsees, their sacred fire, 224

Partridge, C., 257 note 1

Pasiphae, 175

Patara in Lycia, 173

Pausanias, on descendants of Aacus, 239

Peking, 142, 145

Peleus, 239

Pelopida, 240

Pelops, 240, 26 I

Penelope, 26 I

Pepys, quoted, 1 26, 276

Perkunas, 210

Persians sacrifice horses to the sun, 103

Personal qualities of kings, $258 \mathrm{sqg}$.

Peru, sun worship in, 227 sq.

Peruvian Indians, 42, 56, 67, 73, 102

Phrygians, an Aryan tribe, 179

Pictish kings, 242, 247

Picts, the, 246 sq.

Plants, their sexes, 154 sq.; married, I 54 sqg.

Platæa, festival of Dxdala at, 176 sq.

Plautus, on human Jupiters, 282 sq.

Plebeian origin of Roman kings, 250

Pliny, the younger, his affectation, 14

Pliny, on certain electric lights, 33 ; on spinning, 55 ; on sexes of plants, I 54

Plutarch, on cure for jaundice, 48 sqq.; on Egeria, 196 ; on deaths of Roman kings, 274

Poisoned arrows, 56 sq.

Political evolution, conditions of, 82 sqq., 149 sqg.

Pollux and Castor, 32 sq9.

Pope, the Taoist, 143 sqg.

Porta Capena, 22

Positive and negative magic, 52 sqq.

Præneste, 220

Preller, L., on caprificatio, 271 note I

Priest of Nemi, 9, 16, 26, 27, 278 sqq.; an embodiment of Jupiter or Janus, 281 sq9.

Princes reign over their wives' countries, 238 sq9.

Principles of magic, 37 sqq.

Privilege of St. Romain at Rouen, 187 sqq.

Proculus, Julius, 205 
Progress, economic and industrial, accelerated by conquest, $86 \mathrm{sq.;} \mathrm{social}$ progress dependent on division of labour, I 50

Promathion's History of Italy, 219

Public magicians, their importance in history, 82 sqg., 90 s.g., 129 sqg., 149 sq?.

Queen of May, 159, 162 sq9.; Whitsuntide Queen, $16_{5}$ sq. ; queen of Egypt, 171 sq.; of Athens, 174 sq.

Queen of the Wood, Diana as, 26 note 3, 280 sq., 283

Quirinal hill, 205

Quirinus, 205 sq.

Ra, Egyptian sun god, 148 sq.

Races for the kingdom, 260 sq., 264 sq9.; for a wife, $26 i$

Radger, king of the Varini, 244

Rain-dragon, 98 sq.

Rain-makers, in Africa, 112 sq9.; develop into chiefs, $112,116,118$ sq., 120

Rain-making, 92 sq9.

Rajputs, 262

Raven, superstition as to, 69

Ravens give omens, 176 sq.

Red, faces of gods dyed, $198 \mathrm{sq}$.

Regalia, 121 sq7.

Regifugium, 252, $264 \mathrm{sgg}$.

Regillus, battle of Lake, 34

Reinach, S., $22+$ note

Religion preceded by magic, 35 ; gradually displaces magic, 127, 279

Remulus Silvius, 203 sq.

Renouf, Sir Peter le P., quoted, 148

Rex Nemorensis, 9, 153. See also King of the Wood

Rhodian sacrifices to the sun, 103

Roman funerals, $200 \mathrm{sq}$.

Roman kings, 197 spg. ; their mysterious or violent ends, 204 s99., 210,269 , 273 sq9.; married to oak goddess, 217 ; of plebeian origin, 250

Roman kingship, transmitted in female line, 231 s99.; a relizious office, 250 ; abolition of, 251 s9g.

Rome, oak woors at, in early times, 208 sq., 214,274

Romulus, birth of, 219 sp.; his mysterious end, 205, 269; and Remus, 252

Romulus Silvius, 203 sq.

Rouen, St. Romain and the dragon at, 18687.

Rousseau, his theories, 7
Rugen, island of, 224

Rukmini, wife of Krishna, 157

Sabzans of Harran, 155

Sacred Rites, King of the, 258,264

Sacred words, 136 sq.; women, 138 ; texts, I40; marriage, 169 sq7., I 94 sqq., 265 sqq.

Sacrifices, human, $102 \mathrm{sq}$.

Saints threatened and ill-treated, 100 sq.

Sakalava of Madagascar, 136

Salagrama, a fossil ammonite, 157

Salmoneus, king of Elis, 197, 204

Sandanis the Lydian, 271

Sarawak, 59

Sargon I., king of Babylon, 147

Saturn, personated by Roman and Latin kings, 268 sq., 276 sq., 283 ; god of the seed, 268 ; older god than Jupiter in Italy, 283 ; his human representatives put to death, 267,283

Saturnalia, the, 266 s79.; King of the, 293

Savages, importance of the study of, 6 ; oligarchic government of, $8_{4}$; hidebound by custom, 85 ; absence of real freedom among, 87 ; their idea of godhead, $130 \mathrm{~s} 99$.

Saviour Gods, the, 137

Saxo Grammaticus, Danish historian, $241 \mathrm{sq}$.

Saxon kings marry their stepmothers, 244

Saxony, May and Whitsuntide ceremonies in, 162 sqg.

Schweinfurth, G., 114 sq.

Science in relation to magic, 90 s 99 .

Scrofula cured by king's touch, 126

Scythian kings, their regalia, 124 note 1

Sena, island off Gaul, 224 nose

Serpents, 70

Servius, on Virbius, 24 sq., 26

Servius Tullius, King, his birth, 218 sq., 232 note 3 ; his death, 274

Sex of plants, 154 sq.

Shans of Burma, 62

Siamese modes of making or stopping rain, 99

Sicily, rain-making in, $100 s q$.

Sick, votive offerings of the, 23,45

Silesia, Whitsuntide in, $164 \mathrm{sq}$.

Silvii, Alban dynasty of the, 201399. 216

Silvius, first king of Alba Longa, 202

Similarity, law of, 37 sqg.

Sister's children, preference for, mark of female kinship, 246, 255, 259

Sisters of king, license allowed to, 23589 . 
Sita, wife of Rama, 156 sq.

Sithon, king of the Odomanti, 262 sq.

Sky, Aryan god of the, 290

Slaves, runaway, the priests of Diana, 16 ; Roman kings born of slavewomen, 218 sqg.; slaves succeed to the throne in Africa, 235; female, allowed certain liberties at a festival, 269 sq.

Slavs, Balkan, their holy fire, 224

Smiths sacred, 117

Social progress, its conditions, 84 sqq., $150 \mathrm{sg}$.

Sofala, king of, 133 sq.

Solms-Laubach, Graf zu, 270 note 2

Sorcery, positive magic, 53 sq.

Sowing, season of the spring sowing in Italy, 268

Sparta, kings of, 31,32 sq9., 169

Spartan sacrifices to the sun, $\mathrm{IO}_{3} \mathrm{sq}$.

Spermus, king of Lydia, 242

Spinning, superstition as to, 55

Squirrel, superstition as to, 70

St. Angelo, ror

St. Anthony's fire, 49 sq.

St. Brigit or Bridget, 223 sq9.

St. Columba, 226

St. Francis of Paola, 100, IOI note I

St. George, 19

St. Hippolytus, 25

St. Joseph, IOI

St. Mary in Araceli, 208

St. Michael, ror

St. Ouen at Rouen, 187

St. Romain at Rouen, 186 sq9.

Stammering, cure for, $7 \mathrm{I} \mathrm{sq}$.

Star, the evening, 75 ; the king's, 295

Stars in magic, the fading of the, 50 note 2

Stepmother, marriage with, 244

Stones, magic of, 72 sqg.

Strabo, on priest of Nemi, r6

Succession to kingship, 229 sqg. See also Female Descent.

Suk and Turkana peoples, II 4

Sumatra, 96

Sun, magic applied to, 101 sq9.; human victims sacrificed to, 102 sq.; horses sacrificed to, 103 sq.; goddess of, 147 ; god of, 148 sq.; worship in Peru, 227 sq.; wives of the, 227 sq.

Sundanese, the, 65

Superstition, influence or, $36 \mathrm{sq}$.

Siavamvara, the bride's choice, in India, 262

Sweden, worship of Frey in, 177

Sympathetic magic, 38, 52 sq9.

Syrakoi, their kings, 259
Taboo, negative magic, 52 sg9.; homœopathic and contagious taboo, 59

Tanaquil, Queen, 218

Taoism, religious head of, 143 sgq.

Tarahumares of Mexico, 68, 70, 93

Tarascon, dragon of, 190 note 1

Taro, charms for, 73 sq.

Tarquin the Proud, his attempt to change the line of succession to kingship, 253 sq.

Tarquins, the, 250, 253, 257

Tatius, King, his death, 273

Telamon, 239

Telepathy, savage belief in, 57 sq9., 60 sq9.

Telugus of India, 95

Tenure of kingship limited, 252, 254 , 267,29 I sqg.

Teos, public curses in, 30

Teucer, 239

Thebes in Egypt, 171

Theophrastus, quoted, 2 II sq.; on caprificatio, 270 note 2

Theopompus, on the Etruscans, 248

Things, inanimate, magic of, $72 \mathrm{sgq}$.

Thomas, N. W., 275 note 2

Thompson Indians of British Columbia, 81

Thunder made by kings, 197, 203 sq. ; by spirits of the dead, 206

Tibet, human gods in, 142 sq.

Tifata, Mount, wooded with oaks, 284

Timor, island of, 180

Tirunavayi temple at Calicut, 295

Toaripi or Motumotu tribe in New Guinea, 110

Togo, in West Africa, 106

Toradjas of Celebes, 51 sq., 60 sqq., 72 , 95 sq., 97

Tortoise, superstition as to, 69

Totemism in Central Australia, 107 sq.

Touch, royal, 125 sqq.

Trajan, 13

Trees and plants married, I 54 sqg.

Triumph, costume of Roman generals celebrating a, 197 sq.

Tshi-speaking peoples of Gold Coast, their kings, 235 sq.

Tulasi or Holy Basil, 156 sqg.

Tullus Hostilius, King, 204 sq., 217 , 273 sq.

Tumleo, Papuans of, 78 sq.

Turkana and Suk peoples, I 14

Turkey, superstitions as to the bird, 70

Twins, superstition as to, 206

Tydeus, son of CEncus, 240

Tylor, Prof. E. B., 155

Tyndarids, 32 
Uganda, kingship in, $236 \mathrm{sq}$.; traces of female descent in, 249. Sie also Baganda.

Ulysses, 261

Umbrians, ordeal of battle among the, 275

Upsala, temple at, 177

Varini, the, 244

Varro, on Janus, 286

Vegetation, personification of the powers of, 158 sq., 160 sq9.

Vejovis, 203

Veleda, a deified woman, $138 \mathrm{sq}$.

Ventriloquism, 115

Vespasian, 13

Vesta, title of Diana, 17, 283; oak grove of, 209 ; sacred fire of, 209 ; her title of Mother, 222

Vestal Virgins, 18, 22 sq.; mothers of Roman kings, 219 sq9.; mothers of Latin kings, 219 sq9.; daughters of kings, 233

Victoria Nyanza, Lake, 179

Vines in relation to Diana and Virgin Mary, 19 sqg.

Viracochas, name for Spaniards, 42 sq.

Virbius, 24 sq9., 153, 281, 282 ; Slope of, 274

Virgil, on Alban kings, 201 sq.; as to Capitoline hill, 208

Virgin, Assumption of the, 18 sqq.; of Kevlaar, 45

Virgin birth of Latin kings, 219 sqg., 233 sq.

Virgins wives of the Sun in Peru, 22? sq.

Vishnu, 156 sq.

Vitellius at Nemi, 13

Vocabulary, sacred or princely, 136 sq.

Vulcan, 220

Wagogo of East Africa, 97 sq., 112

Walos of Senegal, 126 sq.

Wanyoro of Central Africa, the, 116

War, customs observed while men are at, 60 sqg.

Warwickshire, May Day ceremonies in, 166 sq.

Water-gods, 23 sq.

Water-spirits, marriage of women to, 179 sg9.; men sacrificed to, 192

Weapon and wound, magical sympathy between, 77 sq.

Weather, magical control of, 92 sqg.
Wells married, 157 sq.

Wends of Saxony, their May customs, $163 \mathrm{sq}$.

White thorn used to keep out witches, 215

Whitsuntide, ceremonies at, 161 sg. ; Whitsuntide king, 164 sqg.; Whitsuntide queen, 165 sq.

Widow of king, marriage with, 242 sq9. Wife, races for, 261 ; athletic contests for, 262 sq.

Wiglet, successor of Hamlet, 242, 244

Wilamowitz-Moellendorff, Prof. U. von, 174 note 2

Wind, charms to raise or calm the, 105 sq.

Wiradjuri tribe in Australia, 108

Witches, Highland, 63 ; kept out by white thorn or buckthorn, 215

Wolf, superstition as to, $7 \mathrm{I}$

Women worshipped by the ancient Germans, $138 \mathrm{sq}$. ; married to gods, 170 sqg.; to water-spirits, 179 sq9.; to fire-god, 218 sqq.; regarded as channel in which royal blood flows, 24159.

Wood, King of the, 9, 16, 26 sq., 152 sq9., 160, 166, 169, 174, 194 sq9., 280 sq9.; an embodiment of Jupiter or Janus, 281 sqq.

Woods unsuitable for housebuilding, 66 ; of Latium, 211 sq.

Wounds, superstitions as to, 77 sqq.

Wyingurri tribe, 80

Xenophon dedicates temple to Artemis, 14

Yams, charms for, 74

Yellow colour as cure for jaundice, 47 sqg.

Yerkla-mining tribe in Australia, 10\$

Yorubas, chieftainship among the, 255 ; their reverence for royal crown, 124 note 1

Yuin tribe in Australia, 109

Zeus, Heavenly, 3 I ; Lacedæmon, 31 ; cured of love, 73 ; kings descender from, 169; married to Demeter, 175 sq.; sacred marriage of, 175 sqq.; Zeus embodied in Greek kings, 196 sq. ; Zeus of Dodona, 200, 213

Zimbas or Muzimbas, of E. Africa, 134

Prinsed by R. \& R. Clark, Limitrin, Edimburgh. 

[IN The PRESS.]

Third Edition. Three Vols. $8 v o$.

\section{THE GOLDEN BOUGH}

A STUDY IN MAGIC AND RELIGION

BY

J. G. FRAZER

HON. D.C.L. OXFORD, HON. LL.D. GLASGOW, HON. LITT.D. DURHAM FELLOW OF TRINITY COLLEGE, CAMBRIDGE

\section{Works by \\ Professor BALDWIN SPENCER and F. J. GILLEN.}

THE NATIVE TRIBES OF CENTRAL AUSTRALIA. By

Prof. BALDWIN SPENCER of the University of Melbourne, and

F. J. Gillen, Sub-Protector of the Aborigines. With numerous

Illustrations. 8 vo. 2 is. net.

THE NOR'THERN 'TRIBES OF CENTRAL AUSTRALIA.

With numerous Illustrations. 8 vo. 2 Is, net.

A Companion Work.

NATIVE TRIBES OF SOUTH-EAST AUSTRALIA. By A. W. HowitT, D.Sc. With Illustrations and Maps. 8vo. 2 Is. net

MALAY MAGIC. Being an Introduction to the Folklore and Popular Religions of the Malay Peninsula. By W. IV. SkEAt. With a Preface by C. O. BLAGDEN. Illustrated. 8vo. 2 Is. net.

By the Same Author. (In the Press.)

WILD RACES OF THE MALAY PENINSULA. Illustrated.

Two vols. 8 vo.

MACMILLAN ANI CO., LTD., LONDON. 


\section{WORKS ON ANTHROPOLOGY.}

THE SHERBRO AND ITS HINTERLAND. By T. J. AllDRIDGE, F.R.G.S. Illustrations and Maps. 8vo. I5s. net.

THE MYSTIC ROSE. A Study of Primitive Marriage. By ERNest Crawley, M.A. 8vo. I2s. net.

THE SOUL OF A PEOPLE. An Account of the Life and Belief of the Burmese. By H. Fielding Hall. Fourth Edition. Extra Crown 8vo. 7s. 6d. net.

JAPAN : An Attempt at Interpretation. By Lafcadio Hearn. Extra Crown 8vo. 8s. 6d. net.

TRAVElS IN WEST AFRICA. By Mary H. Kingsley. Abridged Edition. Extra Crown 8vo. 7s. 6d.

WEST AFRICAN STUDIES. With an Appendix on the Niger Delta by the Vicomte de Cardi. By Mary H. Kingsley. Illustrations and Maps. 8vo. 2 Is. net. Cheaper Edition with additional chapters, but excluding de Cardjs Appendix. Extra Crown 8vo. 7s. 6d.

UNKNOWN MEXICO: A Record of Five Years' Exploration in the Western Sierra Madre, the Tierra Caliente of Tepic and Jalisco, and among the Tarascos of Michoacan. By CARL Lumholtz, M.A. With Coloured and other Illustrations. Two vols. Super Royal 8vo. 50s. net.

LIBYAN NOTES. By David Randall-Maciver, M.A., and Anthony Wilkin, B.A. With 25 full-page Plates and a Coloured Frontispiece. Royal 4to. 20s. net.

HISTORY OF MANKIND. By Professor Friedrich Ratzel. Edited by E. B. TyLor, D.C.L., F.R.S. Royal 8vo. Three vols. I 2s. net each. Or in 30 parts. Is. net each.

THE HISTORY OF HUMAN MARRIAGE. By EdwARd Westermarck, Ph.D., Lecturer on Sociology at the Unive ity of Helsingfors. With Preface by Dr. A. R. Wallace. Third Edition. 8vo. 145. net.

MACMILLAN AND CO, LTD., LONDON. 
n.

- 0

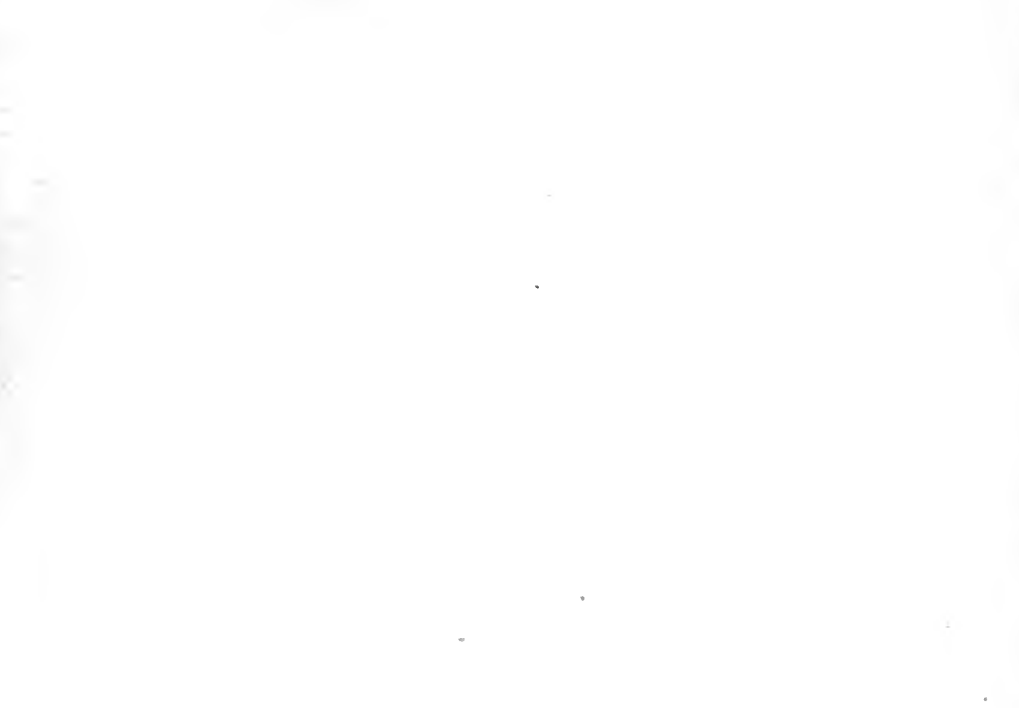

1.2.
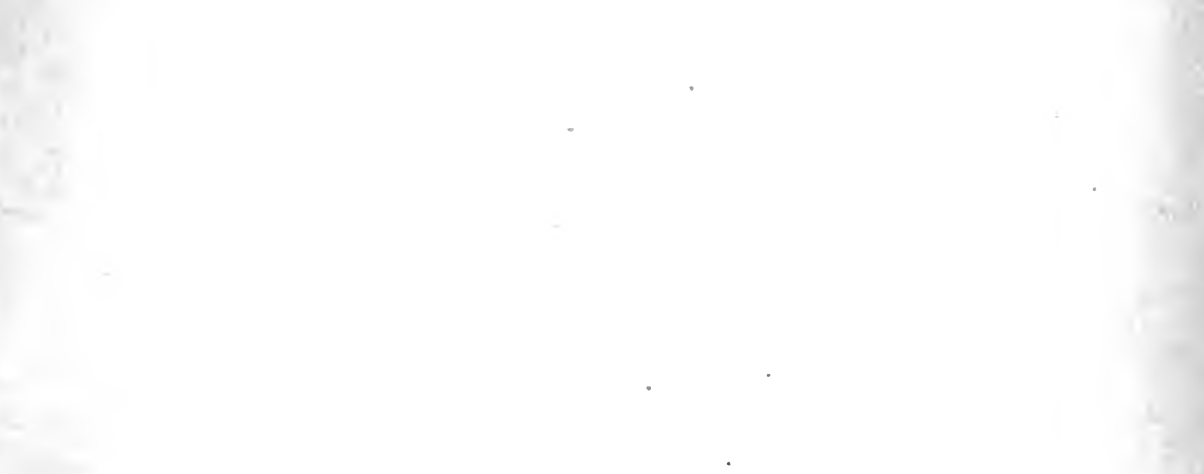

2 



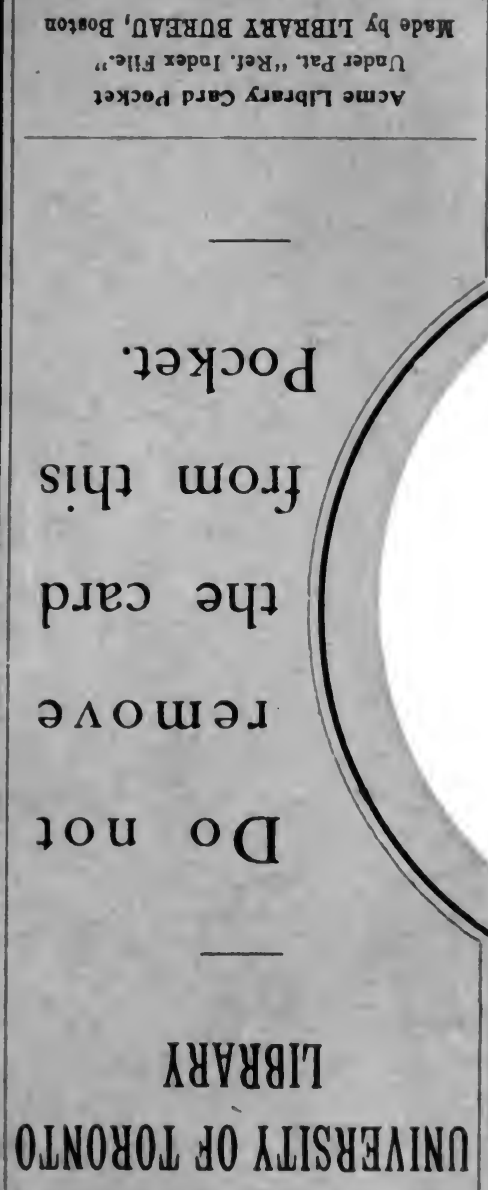


